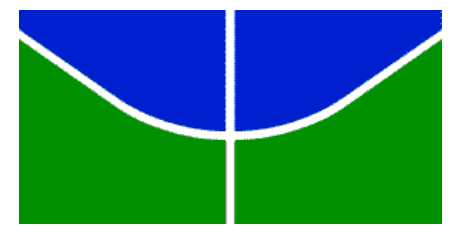

UNIVERSIDADE DE BRASÍLIA - UnB

Instituto de Ciências Biológicas Instituto de Física Instituto de Química Faculdade UnB Planaltina

Programa de Pós-Graduação em Ensino de Ciências

Mestrado Profissional em Ensino de Ciências

\title{
A CONSTRUÇÃO DE UMA UNIDADE DIDÁTICA A PARTIR DO VENENO DO SABER: INSERINDO OS CONTEÚDOS PROCEDIMENTAIS E ATITUDINAIS NO ENSINO DE SERPENTES
}

ANTONIA ADRIANA MOTA ARRAIS 


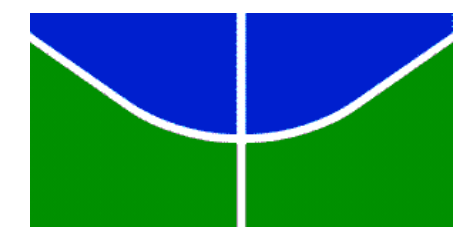

UNIVERSIDADE DE BRASÍLIA - UnB

Instituto de Ciências Biológicas

Instituto de Física

Instituto de Química

Faculdade UnB Planaltina

Programa de Pós-Graduação em Ensino de Ciências

Mestrado Profissional em Ensino de Ciências

\section{A CONSTRUÇÃO DE UMA UNIDADE DIDÁTICA A PARTIR DO VENENO DO SABER: INSERINDO OS CONTEÚDOS PROCEDIMENTAIS E ATITUDINAIS NO ENSINO DE SERPENTES}

ANTONIA ADRIANA MOTA ARRAIS

Dissertação elaborada sob orientação da Prof. ${ }^{a}$ Eliane Mendes Guimarães e coorientação do Prof. Delano Moody Simões Soares apresentado à banca examinadora como requisito parcial à obtenção do Título de Mestre em Ensino de Ciências pelo Programa de Pós-Graduação em Ensino de Ciências da Universidade de Brasília. 


\section{FICHA CATALOGRÁFICA}

Arrais, Antonia Adriana Mota

A Construção de uma Unidade Didática a partir do Veneno do Saber: Inserindo os Conteúdos Procedimentais e Atitudinais no Ensino de Serpentes. Antonia Adriana Mota Arrais. Brasília, Programa de Pós Graduação em Ensino de Ciências (PPGEC) - Universidade de Brasília, 2016.

$159 \mathrm{p}$.

Dissertação de Mestrado - Universidade de Brasília, PPGEC.

Área de Concentração: Ensino de Ciências.

1. Ciências Naturais. 2. Ensino de Zoologia. 3. Ensino de Serpentes. 4. Conteúdos Procedimentais. 5. Conteúdos Atitudinais I. Título. 


\title{
FOLHA DE APROVAÇÃO
}

\author{
Antonia Adriana Mota Arrais
}

\begin{abstract}
"A construção de uma unidade didática: inserindo os conteúdos procedimentais e atitudinais no ensino de serpentes"
\end{abstract}

Dissertação apresentada à banca examinadora como requisito parcial à obtenção do Título de Mestre em Ensino de Ciências pelo Programa de PósGraduação em Ensino de Ciências (PPGEC) da Universidade de Brasília (UnB).

Aprovada em 4 de março de 2016.

BANCA EXAMINADORA

Profa Dra Eliane Mendes Guimarães - FUP / UnB

(Presidente)

Profa Dra Maria de Lourdes Lazzari de Freitas - FUP / UnB

(Membro Titular)

Profa Dra Alice Melo Ribeiro - IB / UnB

(Membro Titular)

Profa Dra Jeane Cristina Gomes Rotta - FUP / UnB

(Membro Suplente) 


\section{DEDICATÓRIA}

Dedico este trabalho ao meu grandioso, digníssimo e esplêndido Deus. A minha família, minha base fortalecedora e única. Aos meus orientadores, Eliane Mendes e Delano Moody, pelo apoio, dedicação e esforço, aos meus alunos e a todos que acreditam que a Educação é um instrumento poderoso de transformação. 


\section{AGRADECIMENTOS}

Agradeço, primeiramente, à Deus por permitir a realização desse sonho, por nunca me abandonar diante das dificuldades e empecilhos do dia-a-dia e sempre me fornecer vontade para lutar e dar o melhor de mim.

Agradeço a minha mãe, Antonia Avaneide, a melhor pessoa que eu já conheci e, que sempre faz de tudo pelo meu crescimento pessoal, profissional e acadêmico. Você é tudo na minha vida!

Agradeço ao meu pai, José Duvaldo, por todo o cuidado e carinho atribuído a mim e, também pelos preciosos ensinamentos. Você não existe!

Agradeço a minha irmã, Juliana Arrais, que mesmo com todas as nossas diferenças, sempre me sustenta e apoia quando preciso. Você é uma linda!

Agradeço a minha família e, em especial, a Ana Nilda, Ananias Dorgival, Anivaldo Mota, Eremita Mota, Francisco Valdo, Jhonnatan Arrais, José Teotônio, Josefa Neide, Lidiane Mota, Maria Socorro, Nelson Neto, Ronald Mota, Ronaldo Máximo, Rosa Balbina, Tatiane Mota, Thays Mota, Vanderlúcia Mota e Yara Mota, por servirem de alicerces e exemplos para o meu crescimento.

Agradeço ao meu gatinho Bilu, por estar comigo nos períodos de escrita, na cama, no colo, no notebook, na cadeira.

Agradeço aos meus amigos mestrandos, quase mestres, Lays Martins, Rodrigo Xavier e Samara Anjos, por compartilhar dos mesmos medos, pelas infinitas caronas e pelo ombro amigo. Vocês são especiais!

Agradeço a todos os meus amigos da vida e, em especial, a Allyne Julyane, Ana Luiza, Aparecida Lúcia, Ariadna Amador, Bárbara Royce, Bruno Rodrigues, Djalma Martinhão, Erica Portela, Erica Sousa, Fabíola Linhares, Felipe Cardia, Francisco Sampaio, Isabele dos Anjos, Gabriela Gonçalves, Grasiela Cardoso, Gerson Cesár, Jhennifer Linhares, Josı 
Andrade, Karoline Cunha, Marco Antônio, Paola Côrtes, Pedro Lucivaldo, Rafael Nunes, Rafael Sampaio, Sérgio Lucena, Suellen Godoi e Yago Araújo, pelas palavras de apoio e incentivo durante essa nova etapa da minha jornada acadêmica.

Agradeço a todos os meus amigos da graduação, que apesar de alguns permearem outras áreas, continuam sendo profissionais de renome: Aline Sampaio, Andrezza Romênia, Bruna Alves, Diego Jácome, Dilmar Barreto, Gabriela Dutra, Ivaneide Alves, Júlia Viegas, Larissa Costa, Luana Maria, Karine Ribeiro e Raphael Fernandes.

Agradeço aos meus lindos e digníssimos pibidianos, professores que se esforçam para tornar as aulas de Ciências Naturais mais atrativas e dinâmicas: Adailton Roger, Ariela Batista, Edelvan Correia, Gaby Camargo, Larissa Batista, Lucas Freitas, Margarete Mendes e Sthéphany Vitória. Vocês enriquecem a minha prática didático pedagógica e, a minha vida, é claro!

Agradeço a toda a equipe do Centro de Ensino Fundamental 03 de Planaltina DF, por fornecer aporte e apoio para realização de atividades diferenciadas, sempre com ótima disposição e capacidade colaborativa.

Agradeço aos meus alunos do $9^{\circ} \mathrm{D}$ e, em especial, a Bianka Martins, Brisa Vitória, Carlos Ascensão, Diego Moreira, Luiz Flávio, Richard Santos e Viviane Farias, pelo auxílio prestado na Feira de Ciências e pelos milhares de sorrisos arrancados do meu rosto.

Agradeço a todos os sujeitos da pesquisa e, em especial, aos que participaram do minicurso "O ensino de serpentes: inserindo conteúdos atitudinais e procedimentais".

Agradeço ao MsC. Alberto Gomes, por facilitar os trâmites que possibilitaram a ida ao Serpentário e por todo o apoio fornecido durante a realização dessa pesquisa.

Agradeço a Prof. ${ }^{a}$ Dr. ${ }^{a}$ Renata Razuck, pelas palavras de apoio, pela meiguice, ins incentivo. Você é uma pessoa maravilhosa! 
Agradeço a Prof. ${ }^{a}$ Dr ${ }^{a}$. Alice Melo, pelo apoio, motivação e oportunidade para participar dos projetos e das disciplinas e também por aceitar participar da banca examinadora.

Agradeço a Prof. ${ }^{\text {a }}$ Dr ${ }^{\text {a }}$. Maria de Lourdes, por me aceitar como participante do projeto de sexualidade, por ser esse ser humano encantador e iluminado e também por ter aceitado o convite para participar da banca examinadora.

Agradeço ao Prof. ${ }^{a}$ Dr ${ }^{a}$. Jeane Rotta, por todas as oportunidades concedidas ao longo da graduação e também por participar dessa banca examinadora.

Agradeço ao meu professor Prof. MsC. Franco Salles, por ter me fornecido dicas valiosas para a entrada no mestrado e, também pelo convite fornecido juntamente com o Prof. Dr. Delano Moody, para ser Professora Supervisora do Programa Institucional de Bolsa de Iniciação à Docência.

Agradeço a minha linda orientadora, $\operatorname{Prof}^{\mathrm{a}}$. Dr ${ }^{\mathrm{a}}$. Eliane Mendes, por me ter me aceitado como orientanda, pelas discussões, pelas infinitas contribuições, por despertar o meu olhar para os conteúdos procedimentais e atitudinais, subsidiando a melhoria da minha prática em sala de aula. Você é fantástica!

Agradeço ao meu coorientador, Prof. Dr. Delano Moody, por me ter me aceitado como coorientanda, pelas sacadas geniais ao longo da pesquisa, por sempre topar trabalhar comigo, pelas contribuições, pois sem ele não seria possível a efetivação dessa dissertação.

Agradeço ao PPGEC e às pessoas envolvidas nesse mestrado, principalmente aos professores, que foram sempre comprometidos com o desenvolvimento do Programa.

Agradeço a todos que me auxiliaram direta ou indiretamente para a realização dessa conquista. 
"Eu não vim até aqui pra desistir agora"

(Engenheiros do Hawaii) 


\section{RESUMO}

O ensino de ciências atual tem sido demarcado pelo mero processo de transmissão e recepção de informações, não privilegiando estratégias metodológicas pautadas na investigação científica. Fator este que vem desencadeando pleno desinteresse nas aprendizagens no que concerne aos temas das Ciências Naturais, dentre eles o de Zoologia. A excessiva valorização de conteúdos conceituais que visa somente à aquisição de fatos, princípios e conceitos acaba por desmerecer a aquisição de outros conteúdos, como os procedimentais e atitudinais, considerados imprescindíveis para o estabelecimento do processo de ensino e aprendizagem dos educandos. Seguindo esta premissa é que o presente estudo visou construir e aplicar uma unidade didática, baseada na análise realizada do material "O Veneno do Saber - Construindo Conhecimento no Serpentário do Jardim Zoológico de Brasília" (BRITO, 2012), com o intuito de avaliar a possibilidade do recurso elaborado desenvolver/demonstrar os elementos intrínsecos aos procedimentos e atitudes frente ao ensino da temática de serpentes. A ação educativa foi desenvolvida e aplicada no formato de minicurso, tendo como participantes 21 educandos que cursavam o $6^{\circ}$ ano do Ensino Fundamental de uma escola pública de uma cidade satélite do Distrito Federal. Para sistematização e análise dos dados, foram realizadas análises qualitativas, mediante o uso de relatórios construídos pelos bolsistas do PIBID - que também foram mediadores da proposta executada - diários de campo dos alunos e filmagem e fotografias dos encontros. Os resultados indicaram o potencial didático da ação executada para a aquisição de variados procedimentos e atitudes por parte dos aprendizes, conforme os pressupostos teóricos evidenciados por Pozo e Crespo (2009). Sendo a unidade didática um mecanismo norteador para auxiliar o professor na busca pela efetivação do processo investigativo em sala de aula, além de disponibilizar meios para que os alunos se tornem protagonistas do seu processo de ensino e aprendizagem, mediante a reflexão, indagação, criticidade e autonomia, sendo capazes ao final, de elaborar soluções para as problemáticas, atuando de forma cooperativa e em conjunto com os pares. Assim, infere-se que então que o professor deve promover a aquisição dos procedimentos e atitudes por parte dos aprendizes, visando (re) significar o ensino de ciências aos olhos destes.

Palavras-chave: Ensino de Ciências; Ensino de Zoologia; Ensino de Serpentes; Conteúdos Procedimentais; Conteúdos Atitudinais. 


\section{RESUMEN}

La enseñanza de la ciencia actual ha estado marcada por el mero proceso de transmisión y recepción de información, no privilegiar estrategias metodológicas guiadas por la investigación científica. Un factor que ha promovido el desinterés total en el aprendizaje en relación con los temas de las Ciencias Naturales, incluyendo la Zoología, apreciación excesiva del contenido conceptual que tiene como único objetivo la adquisición de hechos, principios y conceptos resulta de desacreditar la adquisición de otros contenidos, tales como procedimentales y actitudinales, considerado esencial para el establecimiento del proceso de enseñanza y aprendizaje de los estudiantes. Siguiendo esta premisa es que el presente estudio tuvo como objetivo construir y poner en práctica una unidad de enseñanza, basado en el análisis realizado del material "Saber veneno - Construcción del Conocimiento en el parque zoológico de Brasilia Serpiente del jardín" (BRITO, 2012), con el fin de evaluar la posibilidad de característica diseñada para desarrollar/demostrar los elementos intrínsecos a los procedimientos y las actitudes frente a la cuestión de las serpientes de educación. La actividad educativa se desarrolló e implementó en el formato de curso corto, con los participantes 21 estudiantes que asistieron al sexto grado de la escuela primaria a una escuela pública en una ciudad satélite del Distrito Federal. Para sistematización y análisis de los datos, análisis cualitativos se realizaron mediante el uso de informes construidos por compañeros PIBID que también se llevan a cabo mediadores propuesta - diarios de campo de los estudiantes y filmaciones y fotografías de las reuniones. Los resultados indican el potencial didáctico de las medidas adoptadas para la adquisición de diversos procedimientos y actitudes de los alumnos, como lo demuestran los supuestos teóricos Pozo y Crespo (2009). Siendo la unidad didáctica de un mecanismo de guía para ayudar al maestro en la búsqueda de la realización del proceso de investigación en el aula, además de proporcionar un medio para que los estudiantes a convertirse en protagonistas de su aprendizaje y enseñanza mediante la reflexión, la investigación, crítica y autonomía, pudiendo terminar, para desarrollar soluciones al problema, el trabajo cooperativo y en función de sus compañeros. Por lo tanto, parece que a continuación, el maestro debe promover la adquisición de procedimientos y actitudes de los estudiantes, en busca de (re) definir la enseñanza de la ciencia en sus ojos.

Palabras clave: Enseñanza de las Ciencias; Educación Zoología; Educación Serpientes; Contenidos procedimentales; Contenidos Actitudinales. 


\begin{abstract}
The teaching of current science has been marked by the mere process of transmitting and receiving information, not privileging methodological strategies guided by the scientific research. This factor has promoted full disinterest in learning in relation to the themes of Natural Sciences, including the Zoology. Excessive appreciation of conceptual contents that aims only to the acquisition of facts, principles and concepts turns out to debunk the acquisition of others contents, such as procedural and attitudinal, considered essential for the establishment of teaching and students' learning process. Following this premise is that the present study aimed to build and implement a teaching unit, based on the performed analysis of the material" Poison's know- Building Knowledge in the Serpentarium Garden Brasilia Zoo" (BRITO, 2012), in order to assess the possibility of feature designed to develop/ demonstrate the intrinsic elements to the procedures and attitudes to the issue of teaching snakes. The educational activity was developed and implemented in the short course format, with the participants 21 students who attended the 6th grade of elementary school to a public school in a satellite city of the Federal District, Brazil. For systematization and analysis of data, qualitative analyzes were performed by using reports built by fellows PIBID - who were also mediators performed proposal - field diaries of students and filming and photographs of the meetings. The results indicated the didactic potential of the action taken for the acquisition of various procedures and attitudes of learners, as evidenced by the theoretical assumptions Pozo and Crespo (2009). Being the teaching unit a guiding mechanism to help the teacher in the quest for realization of the investigative process in the classroom, in addition to providing a means for students to become protagonists of their teaching and learning through reflection, inquiry, critical and autonomy, being able to end, to develop solutions to the problem, working cooperatively and in conjunction with peers. It follows then that the teacher should promote the acquisition of procedures and attitudes of learners, seeking (re) define the teaching of science in their eyes.
\end{abstract}

Keywords: Science Education; Zoology Education; Snakes Education; Procedural Content; Attitudinal Content. 


\section{LISTA DE FIGURAS}

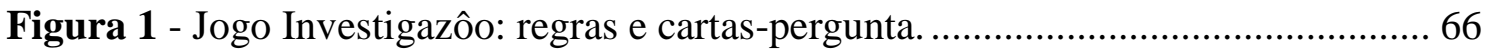

Figura 2 - Seleção de dúvida presente no texto pelo o aluno A1 ..................................69

Figura 3 - Desenho realizado pelo aluno A2 mostrando a situação do olhar do animal

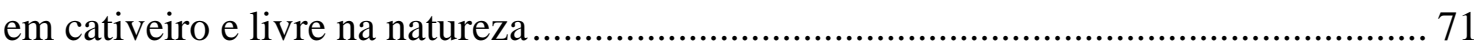

Figura 4 - Organização e interação de um grupo durante as atividades propostas........ 72

Figura 5- Pesquisa realizada pelo aprendiz A17 .................................................. 74

Figura 6 - Discentes comunicando as informações obtidas por meio da pesquisa

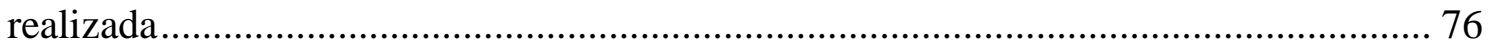

Figura 7 - Material apresentado pelo aluno A7 sobre serpentes.................................. 79

Figura 8- Mapa de ida ao Zôo-DF construídos pelos educandos de um determinado grupo 84

Figura 9- Bilhete confeccionado por determinado grupo........................................... 87

Figura 10- Parte do bilhete construído pelos alunos, solicitando a autorização dos

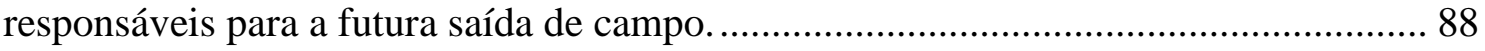

Figura 11- Estudante observando a cascavel utilizada na atividade prática ................. 94

Figura 12 - Desenho do Aluno 9 construído por meio do procedimento de observação95

Figura 13- Alguns crachás construídos pelos educandos ............................................ 96

Figura 14- Alunos realizando procedimento de observação ....................................... 100

Figura 15 - Tabela apontando algumas espécies peçonhentas e não peçonhentas do

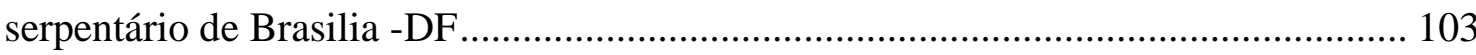

Figura 16 - Pesquisa realizada pelo aluno A2 …..................................................... 107

Figura 17- a) modelos construídos pelos alunos e b) cartazes confeccionados sobre acidentes ofídicos 110 


\section{LISTA DE TABELAS}

Tabela 1 - Categoria dos conteúdos procedimentais estabelecidos por Pozo e Crespo (2009).

Tabela 2 - Categorização adaptada dos conteúdos atitudinais estabelecidos por Pozo e Crespo (2009).

Tabela 3 - Categoria dos possíveis conteúdos procedimentais e atitudinais que podem ser inseridos com a atividade "Nos bastidores: Preparando a Visita"

Tabela 4 - Categoria dos possíveis conteúdos procedimentais e atitudinais que podem ser inseridos com a atividade "Um Pouco da História do Jardim Zoológico de Brasília".

Tabela 5 - Categoria dos possíveis conteúdos procedimentais e atitudinais que podem ser inseridos com a atividade "Curiosidades e Atitudes que marcaram o Zoológico de Brasília",

Tabela 6 - Categoria dos possíveis conteúdos procedimentais e atitudinais que podem ser inseridos com a atividade "Localização, Organização e alguns Dados do Zoológico de Brasília - DF"

Tabela 7 - Categoria dos possíveis conteúdos procedimentais e atitudinais que podem ser inseridos com a atividade "Nem sempre o que parece é! Resíduos da Colonização". .....53

Tabela 8 - Categoria dos possíveis conteúdos procedimentais e atitudinais que podem ser inseridos com a atividade "Anéis do tempo: o número de anéis do chocalho da cascavel indica a idade do animal?".

Tabela 9 - Categoria dos possíveis conteúdos procedimentais e atitudinais que podem ser inseridos com a atividade "Percebendo o ambiente que me cerca!".

Tabela 10 - Categoria dos possíveis conteúdos procedimentais e atitudinais que podem ser inseridos com a atividade "Olho nos Olhos: a Relação entre o Formato da Pupila e as Atividades do Animal".

Tabela 11 - Categoria dos possíveis conteúdos procedimentais e atitudinais que podem ser inseridos com a atividade "Nem tudo que Rasteja é Réptil! Classificando as Serpentes".

Tabela 12 - Categoria dos possíveis conteúdos procedimentais e atitudinais que podem ser inseridos com a atividade "Tira esse Ofídio do Caminho, que eu Quero Passar com meu Trator! Por que as Serpentes Atacam?". 
Tabela 13 - Categoria dos possíveis conteúdos procedimentais e atitudinais que podem ser inseridos com a atividade "No espaço Formal - Concluindo a Atividade". 59

Tabela 14- Organização das atividades desenvolvidas em cada encontro. 63

Tabela 15- Principais conteúdos procedimentais desenvolvidos/demonstrados com a intervenção realizada. 


\title{
LISTA DE SIGLAS
}

\author{
ADPR Atividades Didáticas de Resolução de Problemas \\ CAPES Coordenação de Aperfeiçoamento de Pessoal de Nível Superior \\ EMBRAPA Empresa Brasileira de Pesquisa Agropecuária \\ PCN Parâmetros Curriculares Nacionais \\ PD Partes Diversificadas \\ PIBID Programa Institucional de Bolsas de Iniciação à Docência \\ PPGEC Programa de Pós-Graduação em Ensino de Ciências \\ SCIELO Scientific Eletronic Library Online
}




\section{SUMÁRIO}

1. INTRODUÇÃ

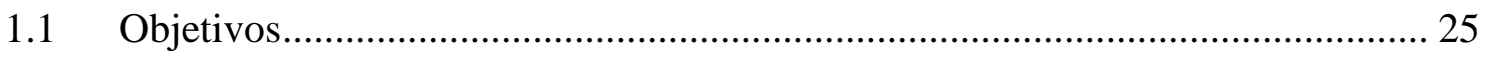

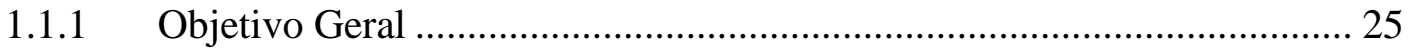

1.1.2 Objetivos Específicos ............................................................................. 26

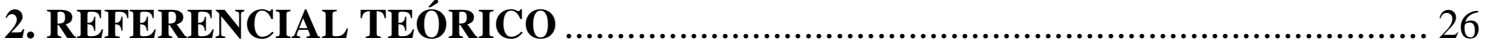

2.1 Conhecendo os Conteúdos Escolares: Atitudinais, Procedimentais e Conceituais .. 26

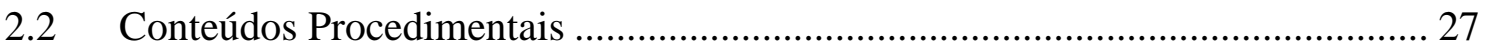

2.2.1 Conteúdos Procedimentais: Definição, Características e Estruturação.......... 27

2.2.2 A Aprendizagem, o Ensino e a Avaliação dos Conteúdos Procedimentais29

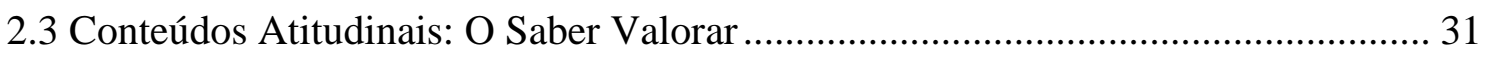

2.3.1 Conteúdos Atitudinais: Significado, Importância e Possibilidades ............... 31

2.3.2 O Papel da Escola e do Docente na Promoção do Ensino-Aprendizado dos

Conteúdos Atitudinais ............................................................................................... 33

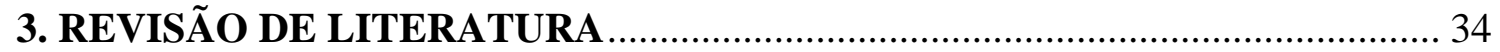

3.1 Um Breve Panorama das Pesquisas sobre os Conteúdos Procedimentais e Atitudinais

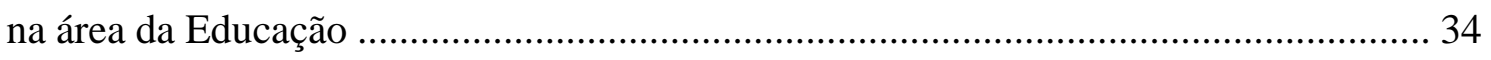

3.1.1 Os Procedimentos e as Atitudes no Ensino de Biologia .............................. 35

3.1.2 Os Conteúdos Procedimentais e Atitudinais na Zoologia ............................. 37

3.1.3 Os Procedimentos e as Atitudes no Ensino de Química e Física ................... 41

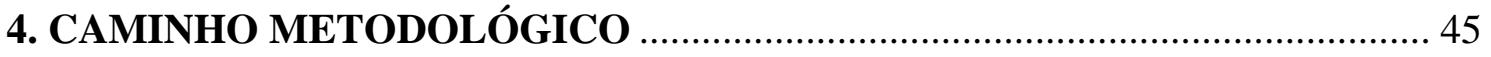

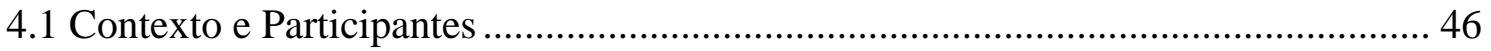

4.2 Procedimentos de Construção de Dados .................................................................... 47

4.2.1 A Análise do Material "O Veneno do Saber - Construindo Conhecimento no Serpentário do Jardim Zoológico de Brasília” ............................................................... 47

4.2.2 Processo de Construção e Aplicação da Unidade Didática .................................... 59

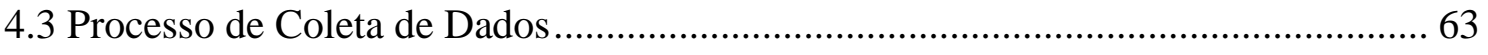

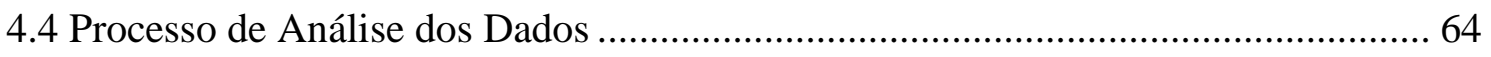

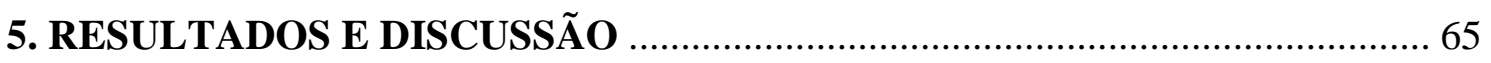

5.1.1 - $1^{\text {o }}$ Encontro (13/08/15) - Conversando sobre o Zoológico de Brasília - DF ..... 65 
5.1.2 - 2 ${ }^{\circ}$ Encontro (20/08/15) - Conhecendo a Situação Atual e a Localização do Jardim Zoológico de Brasília-DF

5.1.3 - $3^{\circ}$ Encontro (27/08/15) - Preparação de Ida ao Zoo-DF - Construção de Bilhetes e Mapas e Discussão Inicial sobre A Importância das Serpentes 83

5.1.4 - 4 Encontro (02/09/2015) - Atividade Prática: Conhecendo as Cascáveis e

Refletindo sobre a Importância das Serpentes 90

5.1.5 - 5 Encontro (10/09/2015) - Visitando o Serpentário do Zoo de Brasília-DF .... 97

5.1.6 - 6 ${ }^{\circ}$ Encontro (16/09/2015) - Retornando ao Espaço Formal: Divulgando

Resultados e Discutindo sobre Acidentes Ofídicos

5.1.7 - $7^{\circ}$ Encontro (25/09/2015) - Relatos sobre Acidentes Ofídicos e Organização da Feira de Ciências 106

5.1.8 - $8^{\circ}$ Encontro (12/12/2015) - Comunicando o Conhecimento sobre Serpentes no Espaço Escolar

5.2 Quadro-Resumo: Os Principais Conteúdos Procedimentais e Atitudinais

Desenvolvidos/Demonstrados nos Estudantes com a Proposta Didática

6. CONSIDERAÇÕES FINAIS

Apêndice A - Termo de Consentimento Livre e Esclarecido.

Apêndice B - Proposição didática: O Ensino de Serpentes: Inserindo Conteúdos 


\section{APRESENTAÇÃO}

Desde muito cedo eu despertei o interesse pela área da Educação. Quando era criança, sempre que indagada sobre qual profissão gostaria de seguir, eu respondia que queria ser professora. Adorava passar tardes inteiras escrevendo no quadro negro com os meus coleguinhas, simulando uma escola. Ao cursar as séries finais do ensino fundamental, tive alguns professores excelentes de Ciências Naturais. Com esse apoio, fui desenvolvendo uma simpatia pelo estudo da natureza, uma vez que a curiosidade me aproximava das temáticas científicas.

Durante o ensino médio, fui bastante incentivada para prestar o vestibular da Universidade de Brasília do $2^{\circ}$ semestre de 2009. Nessa época, não tinha muito contato com a internet, no entanto um professor me deixava a par dos prazos para inscrição na avaliação. Ao escolher o curso, decidi Ciências Naturais por ser uma licenciatura e envolver a área de Biologia. Sinceramente, fiquei surpresa ao ser selecionada.

No primeiro semestre, cursei algumas disciplinas voltadas para a área de educação. Dessa forma, comecei a me apropriar dos problemas que envolvem o ensino de Ciências e a conhecer alguns recursos didáticos voltados para melhoria e facilitação do processo de ensino-aprendizagem das temáticas científicas, mediante a disciplina de Ensino de Ciências.

Apesar de ser apaixonada pela docência, durante a graduação tive a oportunidade de estagiar na Empresa Brasileira de Pesquisa Agropecuária (Embrapa Cerrados), na área de fertilidade dos solos. Essa experiência foi enriquecedora para o meu desenvolvimento profissional, acadêmico e pessoal. No entanto, no final do curso de Ciências Naturais, decidi ir ao encontro de programas voltados para a formação inicial. Logo, o Programa Institucional de Bolsa de Iniciação à Docência (PIBID) me recebeu de braços abertos. Com esse projeto, vivi a experiência de preparar, observar e aplicar aulas, conhecendo o meio escolar e reafirmando a minha escolha profissional. Também participei de um projeto intitulado "Educação Científica para o Ensino de Biologia: Experimentação em Foco”, visando revitalizar um laboratório didático de Biologia de uma escola pública do Distrito Federal, contribuindo para verificar as adversidades advindas dessa área e do "Projetos Interdisciplinares em Ensino de Ciências - A FUP vai para as escolas em Planaltina - DF”, ministrando minicursos no âmbito da sexualidade para adolescentes de escolas públicas.

Nesse período, fui monitora da disciplina de Zoologia Geral, durante três semestres. Essa subárea da Biologia sempre me chamou atenção, visto que gosto muito dos animai 
especial os anuros. Devido a esse fator, redirecionei o meu Trabalho de Conclusão de Curso, intitulado de "O Ensino de Zoologia por meio de Metodologias Diferenciadas: o Caso dos Anfíbios", para essa área, com o propósito de confeccionar um jogo didático para o ensino de anfíbios, visto que a maioria dos indivíduos possui repulsa e desprezo por esses animais, não reconhecendo a sua devida importância.

Ao concluir minha graduação, pretendi dar continuidade aos meus estudos, e participei da seleção para o Mestrado Profissional em Ensino de Ciências, propendendo aperfeiçoar a minha prática docente, considerando a relevância de aprimorar os meus conhecimentos para exercer a minha profissão de forma mais eficiente, vislumbrando também a aquisição de novas metodologias e estratégias de ensino para revigorar as aulas de Ciências Naturais.

Atualmente, sou Professora de Ciências Naturais da Secretaria de Estado de Educação do Distrito Federal e Supervisora do PIBID, atuando juntamente com os bolsistas de Iniciação a Docência, sob a orientação dos coordenadores desse projeto. Tal programa tem sido muito importante para a minha prática didático-pedagógica, posto que por meio dessa formação, os bolsistas trazem ideias novas para as aulas de Ciências e acabam aprendendo a lidar com situações antes de ser tornar um professor formado, instaurando uma troca de experiências e ideias.

Assim, atuando no âmbito escolar e participando de inúmeras conversas e debates com os meus orientadores, apoiados nas discussões de Pozo e Crespo (2009), percebeu-se a priorização que é dada ao ensino de conceitos, em detrimento com os outros tipos de conteúdos: procedimentos e atitudes, no ensino de ciências, conforme é apontado na literatura. Com isso, pensou-se em elaborar um material norteador para que o professor em sala de aula, ancorado em um processo mediacional, pudesse desenvolver nos aprendizes os conteúdos procedimentais e atitudinais. O tema selecionado para o recurso foi relativo às serpentes, entendendo que esses animais, às vezes, provocam diversas sensações negativas nos seres humanos e que é um assunto que desperta interesse e curiosidade nas pessoas. A unidade didática foi baseada em um material já existente sobre os ofídios, mas que ainda não havia sido implementado em sala de aula de modo a avaliar, de maneira mais completa, o desenvolvimento/demonstração dos conteúdos procedimentais e atitudinais.

Com a proposta, buscou-se contribuir para a efetiva melhoria do Ensino de Zoologia, especialmente no que concerne as serpentes, instaurando uma prática investigativa que levasse os alunos a refletirem, questionarem, formularem hipóteses, sistematizarem dados e comunicarem informações, de forma colaborativa e cooperativa. $\mathrm{O}$ intuito também foi 
fornecer suporte ao docente que tem a intenção de trabalhar com o ensino de serpentes, em um ambiente diferente do tradicional, como no caso do serpentário do Zoo de Brasília-DF. 


\section{INTRODUÇÃO}

O ensino de ciências não tem despertado a atratividade e a curiosidade de alguns educandos por apresentarem resistência ao modelo tradicionalista imposto e por sentirem dificuldade para integrar-se ao campo da ciência, acabando por não exercer um olhar crítico e reflexivo acerca das temáticas e abordagens veiculadas no âmbito educacional (CACHAPUZ; PRAIA; JORGE, 2004; KRASILCHIK, 2000; POZO; CRESPO, 2009). O modelo tradicional é marcado pelo processo de transmissão-recepção de informações entre educandos e professores, sendo minimizadas as interações entre alunos-alunos para a troca de significados (CARVALHO et al., 2009). Delizoicov e Angotti (2009, p. 32) acrescentam que este método está focado em atividades que priorizam:

[...] "regrinhas e receituários; classificação taxonômica; valorização excessiva pela repetição sistemática de definições, funções e atribuições de sistemas vivos e não vivos; questões pobres pra respostas prontas igualmente empobrecidas; uso indiscriminado e acrítico de fórmulas e contas em exercícios reiterados; tabelas e gráficos desarticulados ou pouco contextualizados, relativamente aos fenômenos contemplados; experiências cujo único objetivo é a "verificação" da teoria".

Esse enfoque contribui para o desinteresse e a desmotivação dos discentes perante o estudo das ciências, onde os mesmos acabam por assumir atitudes inadequadas no que se refere ao conhecimento científico, adotando uma postura passiva mediante as problemáticas que envolvem o cotidiano escolar (POZO; CRESPO, 2009). De acordo com Cachapuz, Praia e Jorge (2004), essa passividade pode ser justificada pelo caráter transmissivo que é imposto por grande parte dos docentes, onde tal forma acaba por asfixiar o ensino investigativo, uma vez que o educando é considerado um indivíduo que não possui opiniões e indagações acerca dos fatos científicos, não sendo potencializada a construção do conhecimento a partir das suas concepções prévias. Dessa forma, é função primordial da escola ensinar o modo de construção do saber, tendo em vista que os estudantes desenvolvam autonomia para julgar o que lhe é oferecido, considerando que uma determinada situação, fato histórico ou problema pode ter diversas interpretações (LAVILLE; DIONNE, 1999).

Ainda nessa perspectiva, enaltece-se então a relevância de instaurar um modo construtivo e investigativo no que tange o ensino de Zoologia, considerando que essa área das Ciências Naturais, que tem por finalidade estudar diversos aspectos dos animais, conforme o seu contexto evolutivo-ecológico, também apresenta algumas adversidades no que concerne a 
sua significativa aplicação como, por exemplo: a) implementação exclusiva do livro didático; b) escassez de materiais didáticos; c) falta de atividades em espaços não formais, como zoológicos e museus; d) carência da utilização dos laboratórios didáticos; e) profissionais desmotivados e despreparados e f) foco apenas no ensino de conteúdos conceituais, priorizando abordagens descontextualizadas e passivas (ARRAIS, 2013; SANTOS; FACHÍNTERÁN, 2013;).

Conforme os Parâmetros Curriculares Nacionais (PCN), a Zoologia na Educação Básica possui um enfoque exacerbado nas características dos animais, facultando que os aprendizes apenas memorizem táxons e terminologias, sem priorizar uma aprendizagem voltada para o estudo da importância das interações entre os seres vivos, onde não evidencia o contexto no qual se deu o aparecimento de alguns animais, além disto, não abarca questões articuladas para a atualidade como a biodiversidade, biotecnologia e a sustentabilidade (BRASIL, 1998a).

Além do mais, existe uma excessiva valorização dos conteúdos conceituais, que visam apenas à aquisição de conceitos, fatos e princípios apresentando uma desproporcionalidade no que tange a aquisição de outros conteúdos, como é o caso dos procedimentais e atitudinais (COLL, 1998). Os conteúdos conceituais englobam os fatos, conceitos e princípios. Os conceitos juntamente com os princípios são de cunho teórico e exigem uma compreensão, um significado. São exemplos de conceitos: réptil, cidade, potência e outros. São princípios, as leis ou as regras, como por exemplo, as leis de Newton. Já os fatos são informações que declaram algo sobre o mundo, aprendidos de forma literal, de modo reprodutivo, como por exemplo: datas, dados numéricos e outros (POZO; CRESPO, 2009; ZABALA; ARNAU, 2010).

Assim, os PCN sugerem que [...] "da mesma forma que os conceitos (os conteúdos explicativos das Ciências Naturais), também são conteúdos para planejamento, ensino e aprendizagem os procedimentos, as atitudes e os valores humanos" (BRASIL, 1998b, p. 29). Considerando que tais elementos são importantes para o ensino de ciências, haja vista que é crucial que os educandos desenvolvam habilidades para construir um gráfico ou uma tabela, saibam analisar e comparar uma determinada informação oriunda de várias fontes, comunicar suas ideias e ainda, envolver-se em um trabalho colaborativo e de busca conjunta, por exemplo, favorecendo a construção do conhecimento científico (GUIMARÃES; FALCOMER, 2013; POZO; CRESPO, 2009). Além do mais, ao articular os procedimentos e as atitudes, espera-se uma significativa melhoria no ensino de ciências, despertando o interesse do aluno e a sua participação ativa perante o processo de ensino aprendizagem das 
temáticas científicas, rompendo com o modelo tradicional, que prioriza a passividade e a repetição de termos e conceitos científicos (POZO; CRESPO, 2009).

Nesse sentido, propõe-se que no âmbito escolar sejam desenvolvidas outras categorias de conteúdos, consideradas tão ou mais fundamentais que os conceitos, que levem os discentes a aplicar os seus conhecimentos para a resolução de problemas do cotidiano, selecionar informações importantes em determinadas situações; ou, também, agir com respeito em relação ao trabalho dos outros, aceitando a diversidade de opiniões, não discriminando outros indivíduos devido às questões de gênero, raça, idade e etnia (COLL, 1998).

Assim sendo, o ensino de procedimentos é essencial, uma vez que [...] "designam conjunto de ações, de formas de agir e de chegar a resolver tarefas. Trata-se de conhecimentos referentes ao saber fazer coisas (com as coisas, ou sobre as coisas, as pessoas, as informações, as ideias, os números, a natureza, os símbolos, os objetos, etc.)" (COLL; VALLS, 1998, p. 92). Com a aprendizagem de procedimentos é possível que os educandos tornem-se indivíduos ativos no processo de construção do conhecimento científico, mobilizando a apropriação de técnicas, habilidades ou destrezas (POZO; CRESPO, 2009). São procedimentos: a seleção e busca de informações em diversas fontes bibliográficas, modos de fazer perguntas, participar de intercâmbios de comunicação e outros.

Da mesma forma, a aprendizagem de conteúdos atitudinais também é fundamental, tendo em vista que a mesma fomenta a promoção de mudanças no que tange a visão de natureza da ciência e suas implicações, valorizando a formação de educandos interessados e reflexivos perante as questões sociais, além de favorecer a construção da autonomia e a adoção de posturas relevantes mediante as relações com seus colegas e docentes (POZO; CRESPO, 2009).

É de suma importância que essa realidade seja (re) formulada e/ou (re) significada por meio da confecção e implementação de novos recursos didáticos e diferentes estratégias nas aulas de Ciências Naturais, tendo em vista que esses materiais, quando bem planejados e com intencionalidades educativas bem definidas [...] "informa, cria, induz à reflexão, desperta outros interesses, motiva, sintetiza conhecimentos e propicia vivências culturais. Sua aplicabilidade enriquece a prática docente” (BRASIL, 1998c, p. 79).

Desse modo, surge a necessidade de construir materiais didáticos e estratégias que tenham a finalidade de propor um ensino de ciências (especificamente o tema serpentes) mais reflexivo, crítico e significativo, haja vista que essa área da Zoologia apresenta diversos equívocos, uma vez que a maioria dos livros didáticos, um dos recursos didáticos mais 
utilizados nas aulas de Ciências Naturais, dispõe de erros conceituais, demonstrando uma perspectiva antropocêntrica e utilitarista em relação a esses animais, focando apenas no estudo da morfofisiologia, sem contextualizar e fomentar aspectos referentes ao comportamento, a importância ecológica, a alimentação, a defesa e a locomoção (SANDRIN, PUORTO; NARDI, 2005).

Além dos problemas descritos anteriormente, relata-se ainda que, no caso específico do ensino de serpentes, apresenta-se um enfoque excessivo no ensino de conteúdos conceituais, onde não exige a mobilização/demonstração de outros conteúdos, como os atitudinais e procedimentais. Mediante tal problema, o material didático "O Veneno do Saber - Construindo Conhecimento no Serpentário do Jardim Zoológico de Brasília" (BRITO, 2012) estabelece sugestões metodológicas para os docentes trabalharem com os educandos as etapas do raciocínio científico, mediante o uso do Zoo de Brasília- DF. Assim, com a finalidade de expandir as possibilidades de utilização desse material desenvolvendo/demonstrando outros conteúdos, a presente pesquisa possuiu a finalidade de avaliar se a unidade didática, " $O$ Ensino de Serpentes: Inserindo conteúdos atitudinais $e$ procedimentais", construída a partir do recurso didático proposto por Brito (2012), juntamente com o processo de mediação, desenvolveu/demonstrou conteúdos procedimentais e atitudinais nos estudantes do $6^{\circ}$ ano, durante um minicurso, conforme as proposições de Pozo e Crespo (2009).

\subsection{Objetivos}

\subsubsection{Objetivo Geral}

A presente pesquisa possuiu como objetivo principal implementar uma nova possibilidade para o uso do material didático "O Veneno do Saber - Construindo Conhecimento no Serpentário do Jardim Zoológico de Brasília” (BRITO, 2012), por meio da construção da unidade didática, "O Ensino de Serpentes: Inserindo conteúdos atitudinais $e$ procedimentais", avaliando se a partir desse recurso e do processo de mediação, puderam ser desenvolvidos/demonstrados conteúdos procedimentais e atitudinais, propostos por Pozo e Crespo (2009), nos educandos do $6^{\circ}$ ano, no tocante ao ensino de serpentes. 


\subsubsection{Objetivos Específicos}

- Analisar o material didático proposto por Brito (2012);

- Elaborar a unidade didática "O Ensino de Serpentes: Inserindo conteúdos atitudinais e procedimentais", baseada no material de Brito (2012);

- Aplicar a unidade didática no espaço escolar e no Serpentário do Jardim Zoológico de Brasília - DF;

- Confeccionar instrumentos visando analisar se os conteúdos procedimentais e atitudinais foram desenvolvidos/demonstrados por meio da implementação da unidade didática em questão.

\section{REFERENCIAL TEÓRICO}

\subsection{Conhecendo os Conteúdos Escolares: Atitudinais, Procedimentais e Conceituais}

Os principais debates educativos e pedagógicos realizados no âmbito escolar permeiam discussões voltadas para os conteúdos escolares. São tratados diversos impasses referentes a esse assunto, desde a sua implementação no currículo, até mesmo as suas tipicidades, uma vez que os conteúdos diferem entre si e apresentam características e intencionalidades específicas (COLL, 1998).

Nesse sentido, Coll (1998, p. 12) define conteúdos como [...] “o conjunto de conhecimentos ou formas culturais cuja assimilação e apropriação pelos alunos e alunas é considerada essencial para o seu desenvolvimento e socialização". Adicionalmente, o mesmo salienta ainda que o ensino e a aprendizagem de conteúdos são relevantes para a construção e a atribuição de valores aos significados, favorecendo o desenvolvimento da capacidade criativa e reflexiva (COLL, 1998).

No entanto, alguns educadores acabam por considerar como conteúdos, apenas os conceitos (COLL, 1998). Nada obstante, sabe-se que apesar desses elementos possuírem um peso excessivo no currículo, não existe apenas esse tipo de conteúdo. Assim, é crucial que haja uma diferenciação dos conteúdos escolares, posto que existem outros, como os atitudinais e os procedimentais. Esses últimos, apesar de serem menos concretos, podem e 
devem ser devidamente planejados e sistematizados na prática docente, tendo em vista que os discentes possuem dificuldade para aprender procedimentos e atitudes por si mesmos, sem a ajuda de um orientador, mediador (COLL, 1998; POZO; CRESPO, 2009).

Mediante tais considerações, a seguinte discussão será focada apenas nos conteúdos procedimentais e atitudinais, tendo em vista que tais elementos norteiam a presente pesquisa.

\subsection{Conteúdos Procedimentais}

\subsubsection{Conteúdos Procedimentais: Definição, Características e Estruturação}

Os conteúdos procedimentais, assim como os atitudinais e os conceituais, possuem um vasto significado para o processo de ensino aprendizagem, tendo em vista que o aprendiz deve aprender a (re) elaborar, modificar e construir conhecimentos relacionados à área de Ciências Naturais, portando, um olhar flexível e crítico, considerando as transformações que a sociedade sofre constantemente (GUIMARÃES; FALCOMER, 2013; POZO; CRESPO, 2009).

A aprendizagem de conteúdos procedimentais no ensino de ciências é extremamente relevante, visto que vislumbra a mobilização e a atuação dos educandos para a construção dos saberes científicos, almejando que os mesmos possam superar desafios e obstáculos na apropriação das técnicas ou destrezas, instaurando um aprendizado diferente do descontextualizado, estático e memorístico, que é bastante difundido no meio escolar (POZO; CRESPO, 2009).

Tais conteúdos são definidos por Coll e Valls (1998) como o conjunto de ações, objetivos ou medidas, orientadas para a realização de uma meta. Por meio dessa conceituação, pode-se verificar que esses conteúdos apresentam tais características: a) instigam a ação dos estudantes, uma vez que se refere a um processo de atuação; b) propõem uma ação ordenada e sistematizada; c) objetivam a realização de uma meta e d) é diferente do explicar e escutar que rotineiramente é empregado nas aulas de Ciências Naturais (COLL; VALLS, 1998; POZO; CRESPO, 2009).

Nesse sentido, os conteúdos procedimentais podem organizar-se da seguinte forma (Tabela 1): 
Tabela 1 - Categoria dos conteúdos procedimentais estabelecidos por Pozo e Crespo (2009).

\begin{tabular}{|c|c|}
\hline \multicolumn{2}{|c|}{ Conteúdos Procedimentais } \\
\hline \multirow{4}{*}{ Aquisição da informação } & Observação \\
\hline & Seleção de Informação \\
\hline & Busca e captação da informação \\
\hline & Revisão da informação \\
\hline \multirow{2}{*}{ Interpretação da informação } & Tradução da informação \\
\hline & $\begin{array}{l}\text { Uso de modelos para interpretar } \\
\text { situações }\end{array}$ \\
\hline \multirow{3}{*}{$\begin{array}{c}\text { Análise da informação e realização de } \\
\text { inferências }\end{array}$} & Análise e comparação da informação \\
\hline & Estratégias de raciocínio \\
\hline & Modos de fazer perguntas \\
\hline \multirow{3}{*}{$\begin{array}{c}\text { Compreensão e organização conceitual da } \\
\text { informação }\end{array}$} & Compreensão do discurso \\
\hline & $\begin{array}{l}\text { Estabelecimento de relações } \\
\text { conceituais }\end{array}$ \\
\hline & Organização conceitual \\
\hline \multirow{3}{*}{ Comunicação da informação } & Expressão oral \\
\hline & Expressão Escrita \\
\hline & Outros tipos de expressão \\
\hline
\end{tabular}

A primeira coluna da tabela indica grupo de procedimentos e a segunda coluna evidencia seus respectivos subgrupos. Por exemplo, um educando pode desenvolver/demonstrar um procedimento de aquisição da informação, quando é capaz de observar, selecionar, buscar, captar ou revisar alguma informação, e assim respectivamente. A categorização facilita a análise minuciosa de cada tipo de procedimento e sua referente especificidade (POZO; POSTIGO, 1994). Essa classificação não remete a uma ordem em que tais procedimentos devem surgir, mas consiste em uma forma de possibilitar que o docente organize ações para que os alunos possam utilizar seus conhecimentos de maneira mais eficiente (POZO; POSTIGO, 1994).

Dessa forma, as propostas que apresentam uma vertente voltada para o desenvolvimento de tais conteúdos possuem o propósito de tornar o educando um indivíduo prático, competente, reflexivo, crítico e hábil para resolver os problemas e as inquietações que circundam o meio no qual vive (COLL et al., 1998).

Para tal, é fundamental que haja uma forma ordenada e sistematizada de agir, compreendendo que a aquisição desses conteúdos não acontece de forma aleatória ou arbitrária. Assim, é papel do educador planejar e orientar a sua prática diária para que tais conteúdos, assim como os conceituais, ganhem espaço e o reconhecimento no âmbito das 
Ciências Naturais (COLL et al., 1998). Também cabe ressaltar que esses conteúdos não dizem respeito aos recursos e aos métodos que os professores utilizam no cotidiano escolar, mas sim as estratégias e os caminhos que o aluno desenvolve para a resolução de determinados problemas.

\subsubsection{A Aprendizagem, o Ensino e a Avaliação dos Conteúdos Procedimentais}

Apesar de cada tipo de conteúdo apresentar as suas especificidades e particularidades, e possuírem distinção pedagógica, é crucial que os mesmos recebam tratamento equitativo na prática diária. Assim, tais conteúdos devem ser trabalhados de forma integrada, favorecendo a formação de uma rede de significados na estrutura cognoscitiva dos aprendizes, vislumbrando o desenvolvimento global dos sujeitos envolvidos no contexto educativo (COLL et al., 1998).

Com a aprendizagem de procedimentos, espera-se que os educandos realizem suas atuações adotando as seguintes dimensões: a) integração e precisão do conjunto da ação sejam capazes de executar de forma correta o conjunto de passos que compõe o procedimento, aplicando o mesmo a novas situações; b) automaticidade da execução - essa alternativa prevê a redução do tempo que se gasta prestando atenção para realizar ações e utilização do mesmo para compreender o que se está fazendo ou para adiantar etapas; c) composição das ações das quais consta o procedimento - prediz um maior grau de organização, visando reduzir a quantidade de erros e equívocos e d) conhecimento do procedimento - possuam informações suficientes para iniciar a atividade procedimental, demonstrando domínio do quê, como e quando fazer (COLL et al., 1998).

Conforme Coll et al., (1998, p. 109), [...] "na escola, muitos procedimentos são adquiridos simplesmente por contato com as coisas (objetos, situações, símbolos, etc.) que se manipulam ou tratam, sem que exista uma intenção expressa de trabalhá-los”. Devido a esse fator, é essencial que o educador realize um trabalho orientado para a apropriação efetiva das dimensões da aprendizagem dos procedimentos, considerando ainda que esses elementos permeiam diversos contextos além do escolar.

Para tanto, é necessário que aconteça uma seleção dos recursos e estratégias para implementar nas aulas de ciências, almejando o ensino dos conteúdos procedimentais. Segundo Coll et al. (1998), a imitação de modelos e o processo de mediação são ferramentas que auxiliam na construção desse tipo de conteúdo. 
A modelagem favorece que o discente elabore vias e caminhos para construir, de forma autônoma, procedimentos a partir da ação do mediador, onde este demonstra as atuações necessárias para executar uma determinada tarefa, possibilitando assim que os estudantes desenvolvam modelos mentais por meio da observação das ações do orientador, compreendendo que a ciência se constrói a partir de modelos e de modelagem (COLL et al., 1998; POZO; CRESPO, 2009).

A orientação do professor de forma direta e intencional é uma estratégia que visa guiar o estudante para a aprendizagem de procedimentos. $\mathrm{O}$ docente pode auxiliar o aprendiz na aquisição desses conteúdos ao exigir que esses desenvolvam atividades mentais que permeiam atenção e memória, buscando sentido e significado no que está realizando. Nesse sentido, é interessante que o educador foque mais nos processos do que no produto final, analisando os sucessos e os fracassos, os caminhos escolhidos, as dificuldades e os obstáculos, a fim de despertar nos educandos o autocontrole da aprendizagem (COLL et al., 1998).

Atividades de cunho investigativo também podem ser meios norteadores para a aquisição de procedimentos, considerando que estas, geralmente, são constituídas de problemas abertos, que remetem o aluno a refletir, formular hipóteses, comparar informações, discutir e comunicar resultados (CARVALHO, 2013).

Outro eixo importante a ser discutido é o tocante à avaliação da aprendizagem de procedimentos. Conforme Coll et al., (1998, p. 115), é crucial que essas dimensões da aprendizagem sejam avaliadas, averiguando se o educando [...] "possui conhecimento suficiente relativo ao procedimento (sabe-se quais são as ações ou decisões que o compõem, em que ordem devem ocorrer, sob que condições, etc.)" [...], e ainda se sabe aplicar o mesmo a situações específicas.

Assim, o docente pode utilizar instrumentos diferentes com a finalidade de verificar se o aprendiz adquiriu essas dimensões procedimentais, por exemplo, se o objetivo for comprovar a existência do conhecimento referente ao procedimento, como se faz uma observação, uma medida, uma descrição e etc. devem ser lançadas diversas indagações sobre o processo de realização desses procedimentos (COLL et al., 1998).

Quando o intuito for avaliar se o aprendiz sabe fazer o uso adequado e consegue aplicar os procedimentos para a resolução de problemas e inquietações, o educador pode observar as ações que o mesmo realiza, analisando o grau de acerto na escolha dos melhores procedimentos para resolver uma determinada tarefa, o tempo e a atenção que gasta para executar as etapas, dentre outros critérios (COLL et al., 1998). 
Dessa forma, é importante que a tríade ensino-aprendizagem-avaliação esteja sempre conectada e interligada, propondo um ensino de ciências diferente do tradicional, possibilitando que outros conteúdos, além dos conceituais, sejam fomentados a fim de instaurar o desenvolvimento global e integral dos educandos, atuando na formação de cidadãos reflexivos e críticos.

\subsection{Conteúdos Atitudinais: O Saber Valorar}

\subsubsection{Conteúdos Atitudinais: Significado, Importância e Possibilidades}

Educandos desinteressados e desmotivados, com comportamentos inadequados e atos de indisciplina, incomodam bastante o trabalho cotidiano dos docentes. No entanto, pouco tem sido feito para que tal realidade seja transformada, visto que a aprendizagem das atitudes não é tão priorizada nas aulas de ciências, sendo atribuído maior valor e importância à transmissão de conhecimentos conceituais e até mesmo ao ensino dos procedimentos (POZO; CRESPO, 2009).

Nesse sentido, para que as atitudes inconvenientes dos discentes sejam modificadas, é essencial que esse conteúdo assuma um valor explícito e adequado nas atividades propostas, na avaliação e em outros momentos educativos. Com essa intencionalidade, é possível que os estudantes aprendam valores como cooperar e ajudar seus colegas, apresentando bom comportamento durante as aulas e demonstrando interesse pela ciência (POZO; CRESPO, 2009).

Os conteúdos atitudinais compreendem três componentes básicos: a) cognitivo referem-se às normas, elucida como é preciso se comportar perante a sociedade; b) afetivo são os valores, estes por sua vez estão atrelados aos sentimentos e aos princípios e c) comportamental - diz respeito às atitudes, ou seja, a forma de portar-se de maneira consistente (POZO; CRESPO, 2009; SARABIA, 1998).

Assim, as atitudes podem ser definidas como "tendências ou disposições adquiridas e relativamente duradouras a avaliar de um modo determinado um objeto, pessoa, acontecimento ou situação e a atuar de acordo com essa avaliação" (SARABIA, 1998, p. 122). Os valores são referentes aos princípios éticos que estão arraigados nos indivíduos, onde 
os mesmos sentem um forte compromisso emocional para avaliar as suas condutas (SARABIA, 1998). Já as normas seriam [...] "padrões de condutas compartilhadas pelos membros de um grupo social" (SARABIA, 1998, p. 128).

No que tange as ciências naturais, existem três tipos de conteúdos atitudinais que devem versar entre os alunos (Tabela 2):

Tabela 2 - Categorização adaptada dos conteúdos atitudinais estabelecidos por Pozo e Crespo (2009).

\begin{tabular}{|c|c|}
\hline \multicolumn{2}{|c|}{ Conteúdos Atitudinais } \\
\hline \multirow{4}{*}{ Atitudes com respeito à ciência } & Motivação \\
\hline & Gosto pelo rigor e precisão no trabalho \\
\hline & Respeito pelo meio ambiente \\
\hline & Atitude crítica e reflexiva \\
\hline \multirow{5}{*}{$\begin{array}{c}\text { Atitudes com respeito à aprendizagem da } \\
\text { ciência }\end{array}$} & Enfoque profundo \\
\hline & Conduta \\
\hline & Cooperação \\
\hline & Solidariedade \\
\hline & Modelo de atitudes \\
\hline $\begin{array}{c}\text { Atitudes com respeito às implicações } \\
\text { sociais da ciência }\end{array}$ & $\begin{array}{l}\text { Discussão crítica da aplicação da ciência na } \\
\text { sociedade }\end{array}$ \\
\hline
\end{tabular}

Essa tabela evidencia a forma como as atitudes podem ser organizadas em função de seu objeto, onde o professor pode utilizar essa categorização para planejar ou até mesmo avaliar o aparecimento dessas nas suas aulas, tornando estes elementos mais concretos e efetivos no processo de ensino aprendizagem. Assim, um aprendiz pode desenvolver/demonstar uma atitude em relação à ciência, se mostrar-se motivado e empenhado para o estudo da mesma, e assim por diante (GUIMARÃES; FACOLMER, 2013; POZO; CRESPO, 2009).

Com a inclusão desses conteúdos como objeto de ensino, espera-se que ocorram mudanças significativas nas aulas de Ciências Naturais, implementando a promoção da tolerância, cooperação e solidariedade, o espírito crítico e reflexivo, além de despertar nos educandos o interesse pelas questões que permeiam o âmbito científico (POZO; CRESPO, 2009). 


\subsubsection{O Papel da Escola e do Docente na Promoção do Ensino-Aprendizado dos Conteúdos Atitudinais}

A escola, sendo considerada como espaço promotor dos saberes, deve oportunizar que o alunado envolva-se em atividades que proporcionam o desenvolvimento dos valores, das normas e das atitudes, a fim de disseminar um ensino de ciências voltado para a formação cidadã (SARABIA, 1998).

Apesar dos conteúdos atitudinais também serem aprendidos antes de chegar à escola, esse contexto interativo é um dos fatores responsáveis pela formação desses tipos de conteúdos, uma vez que a partir do processo de socialização, os educandos que estão expostos a diversas opiniões, questionamentos e ações, constroem-se por meio dessas, como parte integrante do meio social, utilizando diferentes mecanismos como o reforço social, a aprendizagem com modelos e a internalização para a aprendizagem dos mesmos (SARABIA, 1998).

Dessa forma, o professor atuando como componente da comunidade escolar e sendo o elo entre os alunos e o conhecimento, também age formando as atitudes dos aprendizes, posto que demostram modelos de comportamento, apresentando-se como [...] "uma figura que representa as normas e as expectativas que existem sobre o aluno na escola e é, além do mais, o que realiza uma avaliação escolar em relação ao sucesso ou ao fracasso deste no cumprimento dessas expectativas e da sua acomodação ao sistema” (SARABIA, 1998, p. 150).

Assim, é essencial que o docente utilize ferramentas didáticas a fim de proporcionar um ensino voltado para a formação e a mudança de atitudes. Conforme Sarabia (1998), existem quatro técnicas que os auxiliam nesse processo de mudança: a) role-playing consiste em simular outros papéis de forma ativa. Exemplo: o aluno pode representar o papel do professor, assumindo a responsabilidade de dividir as tarefas, montar os instrumentos, organizar a aula e outros. Logo, “o objetivo é produzir mudanças na percepção e na avaliação da outra pessoa. Em certas ocasiões, a simples observação de outro sujeito representando um papel pode provocar mudanças nas percepções e nas atitudes" (SARABIA, 1998, p. 167); b) diálogo, discussões e técnicas de estudo ativo - esses componentes são capazes de causar mudanças consistentes e duradouras, uma vez que as discussões obrigam aos estudantes criarem e elaborarem argumentos para as diversas situações propostas. Dessa maneira, "tudo que houver reflexão, tratamento e reelaboração pessoal da informação - terá um maior efeito 
nos alunos, reforçando uma atitude positiva em relação ao conhecimento científico" [...]; c) exposições em público - envolve a explicitação de assuntos para o público. Com esse artifício, o aprendiz pode chegar até a desenvolver uma maior aptidão e interesse pela temática, modificando a atitude e o comportamento perante a percepção inicial e d) tomada de decisões - leva os alunos a tomarem frente de suas escolhas, acerca da escola, sociedade e até sobre si mesmo (SARABIA, 1998, p. 168).

Nesse sentido, cabe ressaltar que o processo avaliativo também exerce um papel importante no processo de ensino aprendizado das atitudes. Assim, é crucial que os conteúdos atitudinais sejam avaliados juntamente com os procedimentos e conceitos de forma

interligada. É possível avaliar as atitudes dos alunos por meio da linguagem e das ações manifestas, criando escalas de atitude e utilizando a observação participante para a mensuração das mesmas (SARABIA, 1998).

\section{REVISÃO DE LITERATURA}

\subsection{Um Breve Panorama das Pesquisas sobre os Conteúdos Procedimentais e Atitudinais na área da Educação}

Com a finalidade de analisar e averiguar as produções bibliográficas existentes acerca da aplicação de materiais didáticos/estratégias que visam o desenvolvimento dos conteúdos procedimentais e atitudinais nas Ciências Naturais (Biologia, Química e Física) com ênfase na Zoologia/Serpentes, realizou-se um levantamento bibliográfico nas plataformas online de pesquisa acadêmica, tais como o Google Acadêmico (http://scholar.google.com.br), o Portal de Periódicos da Coordenação de Aperfeiçoamento de Pessoal de Nível Superior (CAPES) (http://www.periodicos.capes.gov.br) e a Scientific Eletronic Library Online (SCIELO) (http://www.scielo.org/php/index.php).

O foco determinado para o levantamento bibliográfico propendeu o estudo de aportes teóricos, sobre a temática, em teses, monografias, dissertações e artigos científicos brasileiros, em língua portuguesa, disponíveis nos referidos mecanismos de busca, compreendendo o período de publicação entre 2006 e 2015.

Para tal, foram introduzidas palavras identificadoras voltadas para o assunto nos campos de pesquisa dos mecanismos de busca. Após essa investigação, foi realizada uma 
leitura flutuante dos títulos e resumos dos trabalhos encontrados, com a intenção de selecionar apenas produções que possuíssem uma vertente para o emprego de recursos didáticos e estratégias voltadas para o desenvolvimento/demonstração das atitudes e dos procedimentos. As pesquisas relacionadas à enfermagem e a educação física, foram descartados dessa fase analítica, já que não eram da área em interesse.

\subsubsection{Os Procedimentos e as Atitudes no Ensino de Biologia}

No primeiro momento, ocorreu uma investigação dos trabalhos que permeiam a área do ensino de Biologia. Diante disto, foram utilizadas as seguintes palavras-chave: "recursos didáticos" "ensino de biologia" "atitudes" "procedimentos" e "recursos didáticos" "ensino de biologia" "conteúdos atitudinais" "procedimentais" para realizar o procedimento de busca. Assim, foram encontrados dezenove trabalhos, sendo sete artigos, três monografias e nove dissertações.

Ao realizar a leitura flutuante, apenas um trabalho apresentou uma ênfase voltada para o uso de recursos didáticos para o desenvolvimento dos procedimentos e das atitudes. Dessa forma, pode-se destacar a dissertação de mestrado intitulada de "Histórias em Quadrinhos e o Ensino De Ciências nas Séries Iniciais: Estabelecendo Relações para o Ensino de Conteúdos Curriculares Procedimentais" (PIZARRO, 2009). Esse estudo envolve a caracterização de práticas, estratégias de ensino e avaliação na aprendizagem dos conteúdos procedimentais na Educação Científica, mediante a inserção de Histórias em Quadrinhos, comerciais, que retratam temáticas de Ciências Naturais, para educandos do $5^{\circ}$ ano do Ensino Fundamental I.

Para a autora, esses recursos possuem uma extrema relevância, uma vez que apresentam [...] "uma linguagem próxima à realidade dos alunos e ser repleta de significados para eles, a presença dos quadrinhos em sala de aula permite que os formalismos do livro didático sejam superados por novas formas de olhar Ciências” (PIZARRO, 2009, p. 7).

Em sua dissertação Pizzaro (2009), aplicou uma intervenção em quatro aulas. Na primeira aula foi introduzida a História em Quadrinhos "Vara de Pescar" de Papa Capim, o indiozinho de Maurício de Sousa, para enfatizar a interferência humana na natureza, onde os estudantes deveriam ler, tirar dúvidas, preencher uma tabela de análise e construir um painel acerca das ações maléficas e benéficas dos seres humanos no meio ambiente e comunicar os resultados (PIZARRO, 2009). 
Na segunda aula, a História em Quadrinhos selecionada foi “Arroz, Feijão e Ovo Frito" de Maurício de Sousa, com a finalidade de subsidiar discussões e questões sobre a alimentação dos seres vivos. Nessa atividade, os educandos tiveram que realizar a leitura do material, questionar, preencher a tabela de análise, utilizar a história para selecionar informações acerca de quais alimentos são oriundos do campo e da cidade e sua origem (vegetal ou animal), discutir quais as funções de produção, consumo e decomposição, elucidar quais são os seus pratos favoritos e os que são de origem rural a fim de classificar os elementos (produtor, consumidor e decompositor) e comunicar os resultados na lousa da sala (PIZARRO, 2009).

Na terceira aula, implementou-se a História em Quadrinhos de Maurício de Sousa, "Bicho Homem", para abordar o estudos da funções dos seres vivos até a formação de cadeias alimentares. Para tanto, os aprendizes tiveram que realizar a leitura da história, preencher a tabela de análise, discutir acerca das relações alimentares entre os seres vivos, selecionar informações para construir cadeias alimentares e expor as hipóteses e os resultados no quadro negro (PIZARRO, 2009).

Na última aula, a História em Quadrinhos empregada foi "Tribunal da Selva", também de autoria de Maurício de Sousa, visando desenvolver temas pertinentes aos seres vivos e a sua sobrevivência. Dessa forma, os discentes tiveram que realizar a leitura, expressar as ideias prévias e responder questões acerca das relações entre os seres vivos, além de evidenciar os resultados encontrados para a turma (PIZARRO, 2009).

Para a avaliação, sugeriu-se que os alunos confeccionassem uma História em Quadrinhos, utilizando os conhecimentos construídos para informar os novos leitores. Os aprendizes contaram com as instruções orais e escritas da educadora para realizar a atividade proposta (PIZARRO, 2009).

Durante a proposição das tarefas, a autora elucidou os conteúdos curriculares procedimentais que foram desenvolvidos/demonstrados em cada momento da proposta. Nos resultados, de uma forma geral, evidenciou-se que os educandos construíram procedimentos, uma vez que as etapas de aquisição, interpretação, análise e inferências, compreensão e organização e comunicação da informação foram evidenciadas com a referida proposta. Assim, os aprendizes tiveram a oportunidade de fazer a leitura das histórias em quadrinhos, levantar hipóteses, registrar dados importantes, correlacionar informações, construir esquemas e tabelas, discutir e comunicar resultados (PIZARRO, 2009).

Mediante a tais fatores, conclui-se que as Histórias em Quadrinhos são recursos promissores para uma efetiva aprendizagem e aquisição de procedimentos no que permeia a 
área de ecologia. No entanto, cabe ressaltar que os mesmos devem estar previamente inclusos no planejamento, para tornarem-se mais viáveis para os docentes traçarem metas, caminho, estratégias e ações que viabilizem a inserção desses na prática docente (PIZARRO, 2009).

\subsubsection{Os Conteúdos Procedimentais e Atitudinais na Zoologia}

O ensino de Zoologia, essa subárea da Biologia, é marcado por um excesso de obstáculos que contribuem para a aprendizagem memorística dos fatos e conceitos, tendo em vista que alguns docentes focam apenas no ensino das caraterísticas morfofisiológicas e nomenclaturas, além de utilizar o livro didático como recurso exclusivo, sem apresentar um caráter investigativo e reflexivo (SILVA et al., 2007).

Consequentemente, diversos autores vêm propondo alguns materiais didáticos com a finalidade de auxiliar o educador a tornar o aprendizado em Zoologia mais significativo, reflexivo e contextualizado (CANDIDO; FERREIRA, 2012; KRASILCHIK, 2005; PIZARRO, 2009).

Para avaliar como são tratados e estabelecidos os conteúdos procedimentais e atitudinais, na área do estudo dos animais, foram analisados treze trabalhos, sendo seis artigos, cinco dissertações e duas monografias, mas apenas dois artigos apresentavam propostas para o desenvolvimento/demonstração dos procedimentos e das atitudes. Para tal, foram utilizadas as seguintes palavras-chave: "recursos didáticos" "ensino de zoologia" "conteúdos procedimentais" "conteúdos atitudinais" e "materiais didáticos" "atitudes" "procedimentos" “ensino de zoologia".

Candido e Ferreira (2012) propõem em seu artigo a implementação de um jogo didático para o estudo de Zoologia dos Invertebrados, no que tange à nomenclatura biológica e no relacionamento de maneira evolutiva entre os diferentes grupos, sugerindo uma revisão de conceitos com perguntas, a fim de estimular o desenvolvimento do raciocínio, a participação e a cooperação dos discentes no processo de construção do conhecimento.

Para as autoras, o jogo didático é um instrumento que possibilita despertar a motivação, o entretenimento e facilita a aquisição dos conceitos. Além do mais, esse material [...] "contribui para a formação de atitudes sociais como companheirismo, honestidade, cooperação, obediência e entendimento das regras, senso de responsabilidade, iniciativa grupal e individual" (CANDIDO; FERREIRA, 2012, p. 23). 
No entanto, apesar das autoras descreverem como sendo um dos objetivos estimular a participação e a colaboração dos grupos de estudantes no momento da aplicação do jogo didático, nos resultados apresentados, o processo de criação do material didático e o aspecto conceitual construído pelos aprendizes foi privilegiado, em detrimento das implicações atitudinais geradas com a inserção do recurso nas aulas de Zoologia (CANDIDO; FERREIRA, 2012).

Outra publicação que se destaca nessa área é o artigo "Conteúdos atitudinais $e$ procedimentais no ensino da metamorfose de borboletas" (GUIMARÃES; FALCOMER, 2013). Este trabalho refere-se ao uso de um borboletário para fomentar a aquisição de conteúdos procedimentais e atitudinais no processo de ensino-aprendizagem da metamorfose das borboletas, utilizando como eixo norteador para a atividade três questões investigativas:

1. Qual o tempo de desenvolvimento da borboleta Ascia monuste do ovo até a fase de acasalamento? 2. A cor da planta que a lagarta se alimenta define a cor da borboleta? 3. Por que quando estão na fase de lagarta elas se alimentam vinte e quatro horas até chegar à fase de pupa e na fase de pupa ela não se alimenta mais? (GUIMARÃES; FALCOMER, 2013, p. 2294).

Com a finalidade de tornar os conteúdos procedimentais e atitudinais, propostos por Pozo e Crespo (2009), mais palpáveis para serem desenvolvidos na prática cotidiana dos docentes, nas aulas de Ciências Naturais do $7^{\circ}$ ano do ensino fundamental, as autoras/pesquisadoras elencaram categorias que salientam os possíveis conteúdos a serem desenvolvidos/demonstrados com a aplicação da proposta (GUIMARÃES; FALCOMER, 2013).

Em vista disso, enfatiza-se que os aprendizes construirão procedimentos, se utilizarem ao decorrer das atividades, as seguintes estratégias: a observação, o registro e a busca de informações sobre as borboletas e sua criação (GUIMARÃES; FALCOMER, 2013).

Dessa forma, ressalta-se que os conteúdos procedimentais serão desenvolvidos/demonstrados, na etapa de observação, registo e interpretação da coleta de dados, se os aprendizes: a) confeccionarem tabelas e gráficos para retratar o crescimento das borboletas; b) relacionarem o alimento e a cor da borboleta e c) correlacionar o consumo de alimento e as fases de desenvolvimento. $\mathrm{Na}$ fase de análise de dados, espera-se que os educandos: a) estabeleçam uma possibilidade de tempo de desenvolvimento das borboletas; b) questionem sobre a validade do experimento realizado; c) estipulem uma relação direta entre o alimento e a cor da borboleta; d) questionem se a cor é definida geneticamente e e) sugiram novas estratégias para a investigação (GUIMARÃES; FALCOMER, 2013). 
Baseadas em Pozo e Crespo (2009), as autoras/pesquisadoras elencaram também os possíveis conteúdos atitudinais a serem construídos com a aplicação da proposta. Assim sendo, espera-se que com relação às ciências, que os aprendizes: a) diferenciem discurso científico de explicação da metamorfose de outros tipos de discurso sobre o desenvolvimento dos organismos; b) comparem a metamorfose de diferentes organismos; c) compreendam que o desenvolvimento é um processo complexo; d) distinguem os tipos de desenvolvimentos de outros organismos e correlacionem ao conceito de vida e a própria existência da diversidade de espécies da Terra e e) relacionem metamorfose a outras concepções históricas (GUIMARÃES; FALCOMER, 2013).

Já em relação à aprendizagem das ciências, anseia-se que os mesmos: a) demonstrem interesse pela temática e b) valorizem a opinião dos colegas, primando pelo debate (GUIMARÃES; FALCOMER, 2013).

E, para finalizar, com relação às implicações sociais das ciências, almeja-se, ainda, que os estudantes: a) relacionem as etapas do ciclo de desenvolvimento de outros organismos com o das borboletas; b) reconheçam o processo de fecundação e de surgimento da vida, valorizando a vida e a manutenção dela em todos os âmbitos e c) debatam acerca da preservação da vida das próprias borboletas Ascia monuste e a produção de alimentos para quem tem fome (GUIMARÃES; FALCOMER, 2013).

A categorização dos conteúdos procedimentais e atitudinais, como realizado pelas autoras/pesquisadoras é primordial para tornar o processo de ensino-aprendizagem dos mesmos mais consistentes e palpáveis, podendo também auxiliar o docente a planejar e a incorporar esses elementos como objetivos a serem alcançados na sua prática pedagógica.

Ao refinar a pesquisa para averiguar os materiais didáticos que fomentam o desenvolvimento/demonstração dos conteúdos procedimentais e atitudinais no ensino de serpentes, inseriu-se no contexto da pesquisa, as seguintes palavras-chave: "procedimentos" "atitudes" "ensino de serpentes" "material didático".

Entretanto, apenas dois trabalhos foram encontrados nesse âmbito. A monografia "Veneno do Saber: Análise de um Material Didático para o Desenvolvimento do Pensamento Científico no Ensino de Serpentes" (SOUTO, 2013) salienta os resultados encontrados por meio da aplicação da material didático: "O Veneno do Saber - Construindo Conhecimento no Serpentário do Jardim Zoológico de Brasília” (BRITO, 2012), no que concerne a aquisição dos procedimentos.

A aplicação da unidade didática confeccionada por meio do material didático foi configurada da seguinte forma: a) implementação das atividades em sala de aula; b) saída de 
campo para o serpentário localizado no Zoológico de Brasília-DF e c) discussão e apresentação dos resultados no âmbito escolar (SOUTO, 2013).

Com a inserção da unidade didática, salientaram-se resultados positivos, uma vez que procedimentos, como: a) aquisição da informação - ao descreverem que já possuíam algumas informações a respeito dos textos distribuídos com curiosidades sobre o Zoológico; b) análise da informação - ao formularem hipóteses para responder as questões investigativas; c) análise de dados e inferência de resultados - ao comparar os dados encontrados nas imagens e correlacionar com as informações do livro didático; d) busca e interpretação da informação ao buscarem informações no serpentário a fim de sanar as dúvidas presentes e e) divulgação da informação - ao comunicar novos conhecimentos adquiridos por meio das atividades propostas (SOUTO, 2013).

No entanto, evidencia-se que o foco dessa monografia era voltada para uma preparação investigativa de visita ao Zoo, utilizando algumas das atividades propostas por Brito (2012). Assim, aponta-se que a presente pesquisa, apesar de utilizar o material didático de Brito (2012) como base para a confecção da unidade didática, possuiu o objetivo de analisar se o recurso didático confeccionado vislumbrou o desenvolvimento/demonstração dos conteúdos atitudinais e procedimentais em um âmbito mais geral e completo.

O outro trabalho encontrado na revisão foi o artigo intitulado de "Uma possibilidade para o desenvolvimento de conteúdos atitudinais e procedimentais no ensino de serpentes: a análise de um material didático”. Esta pesquisa apresenta uma análise do material de Brito (2012), no intuito de elencar os possíveis conteúdos procedimentais e atitudinais a serem desenvolvidos/demonstrados com seis atividades problematizadoras presentes nesse, conforme os pressupostos teóricos de Pozo e Crespo (2009) (ARRAIS; GUIMARÃES, 2015). Com a análise realizada, obtiveram-se categorias de procedimentos e atitudes que podem ser desenvolvidas/demonstradas com a proposta para o ensino de serpentes, principalmente no que diz respeito ao estabelecimento de relações conceituais, busca e seleção da informação, modelização, participação em intercâmbio de comunicação, atitudes de capacidade crítica e reflexiva ação cooperativa e colaborativa. É importante estabelecer tais categorias, já que estas podem tornar esses conteúdos mais concretos para sua efetiva aplicação nas aulas de Ciências Naturais (ARRAIS; GUIMARÃES, 2015). 


\subsubsection{Os Procedimentos e as Atitudes no Ensino de Química e Física}

Visto que existe uma escassez de trabalhos que retratam os conteúdos procedimentais e atitudinais no âmbito da Biologia, principalmente no ensino de Zoologia/Serpentes, verificou-se a necessidade de explorar os estudos desses tipos de conteúdos nas outras áreas das Ciências Naturais: ensino de Química e Física, com a finalidade de buscar contribuições para a pesquisa desenvolvida.

Para efetuar o levantamento bibliográfico dos trabalhos acadêmicos foram utilizadas as seguintes palavras-chave: "ensino de química" "conteúdos procedimentais e atitudinais" "recursos didáticos". Assim, foram encontrados apenas oito trabalhos, sendo duas teses, uma dissertação e cinco artigos.

No entanto, destaca-se apenas o artigo, “Atividades Experimentais em Química através da Metodologia de Resolução de Problemas" (CAVALCANTI; SPRING; BRAGA, 2013), uma vez que o mesmo envolve uma proposta para o desenvolvimento das atitudes e dos procedimentos. Assim sendo, esse trabalho teve como propósito desenvolver uma atividade experimental, de cunho investigativo, por meio da resolução de problemas. A intenção dessa proposta visava que os discentes valorizassem o trabalho em equipe, a capacidade de argumentação e a motivação para resolver situações-problema. "A solução de problemas baseia-se na apresentação de situações abertas e sugestivas que exijam dos alunos uma atitude ativa ou um esforço para buscar suas próprias respostas, seu próprio conhecimento" (CAVALCANTI; SPRING; BRAGA, 2013, p. 760).

Dessa forma, os estudantes receberam um e-mail fictício, enviado pela direção de uma instituição, com uma solicitação aos técnicos laboratoriais para a reformulação dos procedimentos utilizados na prática de preparo de soluções, visando reduzir o uso de reagentes implementados nessa ação. A justificativa para essa redução baseava-se no fato da empresa estar passando por problemas financeiros e, além disso, havia sido denunciada por um órgão ambiental, pelo excesso de resíduos gerados no meio ambiente. Juntamente com o e-mail, os aprendizes receberam um protocolo para auxiliá-los na prática de preparo de soluções (CAVALCANTI; SPRING; BRAGA, 2013).

Durante a execução da atividade, os educandos separados em grupos, tiveram que elaborar alterações para os processos de preparo de solução, e no final enviar um e-mail com as mudanças, justificando o porquê das mesmas e explicitando as vantagens dessas (CAVALCANTI; SPRING; BRAGA, 2013). 
Apesar das autoras/pesquisadoras não terem sistematizado, especificamente, os procedimentos e atitudes desenvolvidos por meio da proposta, ficou evidente que tais conteúdos curriculares foram desenvolvidos/demonstrados, posto que os educandos demonstraram-se motivados para a realização da atividade, exerceram um trabalho cooperativo e focado, debatendo e argumentando entre si, com os outros grupos e com o docente e, além do mais, sugeriram a criação de um projeto com a finalidade de reformular os roteiros dos experimentos da disciplina em questão, com o intuito de reduzir os custos e os possíveis impactos ambientais a serem gerados (CAVALCANTI; SPRING; BRAGA, 2013).

No tocante ao ensino de Física, foram inseridas nos mecanismos de busca as seguintes palavras-chave: "ensino de física" "conteúdos procedimentais e atitudinais" "recursos didáticos". Assim, foram encontrados onze trabalhos, sendo sete artigos, três dissertações e uma tese. Levando em consideração a proposta da revisão, destaca-se o artigo intitulado de “Atividades Didáticas de Resolução de Problemas e o Ensino de Conteúdos Procedimentais" (CLEMENTE; TERRAZAN, 2011). Nesse trabalho, os autores/pesquisadores, elaboraram Atividades Didáticas de Resolução de Problemas (ADRP), numa perspectiva investigativa, para turmas do Ensino Médio, na área de Física, apresentando alguns aspectos relativos ao processo de ensino-aprendizagem, especificamente, dos conteúdos procedimentais atingidos com a efetivação da proposta didática.

As atividades de resolução de problemas são artifícios comumente empregados na prática pedagógica dos professores. Porém, na maioria das vezes, é dada uma ênfase mecânica e quantitativa, na aplicação dessas. Assim, [...] "a resolução acaba se resumindo em simples manipulações matemáticas ou na simples enunciação de princípios e leis físicas, cujas contribuições para a vida diária dos alunos são difíceis de serem identificadas" (CLEMENT; TERRAZZAN, 2011, p. 88).

A fim de mudar essa realidade, os autores pensaram em criar problemas, com cunho investigativo, almejando que os estudantes desenvolvessem autonomia para agir mediante as novas situações-problema, sem o auxílio ou momentaneamente afastados do educador, estimulando os mesmos a pensarem, debaterem, refletirem, (re) elaborarem hipóteses, dentre outros (CLEMENT; TERRAZZAN, 2011).

Assim, os autores entendem que as atividades de resolução de problemas, com caráter investigativo, são ferramentas promissoras para o desenvolvimento dos conteúdos procedimentais. Os mesmos ressaltam ainda, um ponto fundamental da inclusão desses conteúdos no currículo escolar [...] "é a expectativa de que as pessoas, ao concluírem a escolarização básica, saibam fazer o maior número de atividades possíveis com o 
conhecimento construído ao longo de seu processo de escolarização" (CLEMENT; TERRAZZAN, 2011, p. 88).

Em vista disso, a pesquisa envolveu quatro etapas, consistindo na elaboração, na aplicação e na análise das ADPR, com foco nos conteúdos procedimentais, e ainda, em uma entrevista com o docente. Cabe ressaltar que as situações-problema possuíam um caráter aberto, objetivando que os aprendizes tivessem liberdade para traçar diversas respostas e caminhos para as inquietações (CLEMENT; TERRAZZAN, 2011).

Para o efeito da análise, os autores, embasados nos estudos de Pozo e Crespo (2009) criaram categorias com a finalidade de elencar possíveis procedimentos a serem alcançados com a inserção das ADRP, permeando: a) aquisição da informação; b) interpretação da informação; c) análise da informação e realização de inferências; d) compreensão e organização conceitual da informação e e) comunicação da informação (CLEMENT; TERRAZZAN, 2011).

Uma das situações-problema envolvia aspectos relativos à ondulatória, na qual foi apresentada a seguinte indagação: "Um turista estava olhando para o mar, da beira da praia, e percebeu que um jet ski andava de uma extremidade a outra da praia exatamente no intervalo entre as ondas. Qual a velocidade de propagação das ondas?" (CLEMENT; TERRAZZAN, 2011, p. 93). Devido à forma como foi implementado o problema, os alunos conseguiram desenvolver/demonstrar os seguintes conteúdos procedimentais:

\footnotetext{
Ilustração da situação problematizada; busca de conhecimentos de ondulatória para modelizar a situação problema; realização de análises e inferências ao hipotetizar e estimar o movimento realizado pelas ondas do mar e pelo jet ski; preocupação em estimar valores próximos dos reais para as grandezas físicas julgadas por eles fundamentais para a solução da situação-problema (CLEMENT; TERRAZZAN, 2011, p. 94).
}

Com relação às outras situações-problema instauradas, infere-se que procedimentos, como aquisição da informação (selecionar informações úteis, utilizando com ferramenta de pesquisa o caderno, nos livros e em outros), interpretação da informação (ao coletar dados, confeccionar desenhos, relacionando a situações cotidianas), análise e realização de inferências (ao elaborar hipóteses, usar linguagem matemática), compreensão e organização conceitual da informação (verbalizar as resoluções, relacionando conceitos e apontando novos problemas) e comunicação da informação (questionar, compartilhar e argumentar acerca de ideias) foram desenvolvidos/demonstrados com a inserção das ADRP (CLEMENT; TERRAZZAN, 2011). 
Nesse sentido, justifica-se a importância de implantar no âmbito educacional, modelos de aprendizagem diferente do tradicional, objetivando o ensino dos procedimentos, uma vez que esses estão focados na atuação dos aprendizes frente às questões cotidianas e permitindo, ainda, que os mesmos se posicionem e tomem atitudes diante das diferentes situaçõesproblema. A categorização dos procedimentos, conforme apontada pelos autores, facilita a sistematização desses conteúdos como objeto educacional e curricular, possibilitando que o docente planeje as suas aulas de acordo com essas concepções e ainda avalie como ocorreu a apropriação, construção e aquisição desses.

Outro estudo de grande consideração na área é o artigo acadêmico "Construção $e$ Validação de um Sistema Hipermídia para o Ensino de Física Moderna” (MACHADO; NARDI, 2007) que ressalta o processo de construção de um sistema de hipermídia para apoiar o processo de ensino-aprendizagem em tópicos de Física Moderna, evidenciando que a proposta didática possibilitou o desenvolvimento/demonstração de conteúdos procedimentais e atitudinais.

Essa intervenção consistiu em três etapas: elaboração de um sistema hipermídia para favorecer a alfabetização científica e aprendizagem de conceitos de Física Moderna, processo de validação do protótipo por profissionais da área em estudo e à avaliação do software hipermídia por meio de uma situação em sala de aula (MACHADO; NARDI, 2007).

A hipermídia é constituída de textos com imagens, vídeos, animações, filmes e outros, para mediar à abordagem de conceitos relativos à teoria da relatividade, física nuclear, fusão nuclear, radioatividade, reatores nucleares, acidentes radioativos, armas nucleares desenvolvimento histórico da mecânica quântica, projeto Manhattan, biografia de Albert Einstein, buracos negros e ondas gravitacionais (MACHADO; NARDI, 2007).

A sequência didática envolveu as seguintes etapas: “a) explanação inicial do professor; b) exploração pelos alunos de um tópico do sistema hipermídia; c) debate das questões propostas no software em dupla e com o professor; d) debate das questões envolvendo toda a turma e e) resposta individual às questões e entrega do material ao professor" (MACHADO; NARDI, 2007, p. 101).

Com a aplicação da proposta, foi possível analisar a interação dos aprendizes com relação ao curso, ao sistema hipermídia e, também, os indícios de aprendizagem dos conteúdos procedimentais e atitudinais. Nesse sentido, ficou explícita a ocorrência de procedimentos, visto que durante a ação educativa o hipertexto criou hábitos de leitura e fomentou a discussão de ideias, e também de atitudes, uma vez que os aspectos de 
solidariedade e trocas de opiniões foram constantes no momento educacional (MACHADO; NARDI, 2007).

Para finalizar, em consonância com a literatura, reconhece-se que existe uma imensa escassez de trabalhos nas áreas pesquisadas, principalmente no que diz respeito aos conteúdos atitudinais, que na maioria das vezes são avaliados de forma simplória e superficial.

Partindo desse princípio, infere-se que existe uma lacuna a ser preenchida por professores e pesquisadores, no estudo desses conteúdos, especialmente na área de serpentes, instaurando a construção de materiais pedagógicos, metodologias e estratégias de ensino que fomentem o estabelecimento dos procedimentos e das atitudes no âmbito das Ciências Naturais.

Diante disto, a presente pesquisa tem o propósito de contribuir para esse fim, com a construção da unidade didática " $O$ Ensino de Serpentes: Inserindo conteúdos atitudinais $e$ procedimentais", material que pode auxiliar o docente a contemplar a aquisição desses conteúdos no ensino de serpentes, conforme as considerações de Pozo e Crespo (2009).

\section{CAMINHO METODOLÓGICO}

A presente pesquisa possui uma abordagem qualitativa, uma vez que esta [...] “propicia a captação de motivações e ideias não explicitadas, ou até mesmo inconscientes de maneira espontânea. Sendo assim, a pesquisa qualitativa é empregada quando se busca percepções e entendimento geral de uma determinada questão" (MARASINI, 2010, p. 11). Essa "visa, sobretudo, gerar um conhecimento mais aprofundado de um fenômeno, as dimensões complexas de um problema ou tema, envolvendo um número restrito de participantes" [...] (BARBATTO, 2008, p. 16).

Quanto aos procedimentos, caracteriza-se como metodologia professor pesquisador, tendo em vista que esta se concretiza pelo fato do pesquisador, que nesse caso é o professor, fazer parte do próprio contexto em estudo e propor intervenções para solucionar questões básicas relativas a um fenômeno em interesse, coletando dados e interpretando estes à luz de um referencial teórico-conceitual (MOREIRA, 1988). 


\subsection{Contexto e Participantes}

Para o desenvolvimento da unidade didática foi proposto um minicurso no qual os alunos interessados deveriam se inscrever para participar. No entanto, devido ao excesso de educandos interessados, foi realizado um sorteio para preencher apenas a quantidade de vagas ofertadas, os excedentes ficaram na lista de espera. No primeiro momento do minicurso havia 26 participantes, mas ao término do curso tinha apenas 21, a lista de espera não foi utilizada, pois os educandos começaram a evadir, por motivos desconhecidos, por volta do $3^{\circ}$ encontro e como as atividades anteriores eram essenciais para todo o processo de ida ao Zoo, resolveu-se trabalhar apenas com os participantes que eram frequentes.

Assim sendo, as atividades presentes na unidade didática foram aplicadas para 21 educandos do $6^{\circ}$ ano do Ensino Fundamental - Séries Finais, de uma escola da zona urbana de uma cidade satélite do Distrito Federal, onde a pesquisadora é professora e supervisora de um grupo de licenciandos do Programa Institucional de Bolsa de Iniciação à Docência (PIBID) (nas seções posteriores ocorrerá um esclarecimento sobre o projeto em questão).

A escola selecionada para a implementação do minicurso atende do $6^{\circ}$ ao $9^{\circ}$ ano do Ensino Fundamental e o Segmento da Educação de Jovens e Adultos. A mesma apresenta uma estrutura simples, sendo constituída de quadra poliesportiva, sala de recursos, videoteca, biblioteca, laboratório de ciências e informática.

A escolha do público-alvo foi determinada conforme as orientações do Currículo da Secretária de Estado de Educação do Distrito Federal (BRASIL, 2008a; BRASIL, 2008b e BRASIL, 2008c) e dos PCN/Ciências Naturais (BRASIL, 1998). Dessa forma, ressalta-se que essa temática de serpentes pode ser abordada dentro de vários eixos curriculares, como: a) ecologia - cadeia alimentar, relações entre seres vivos, animais em extinção, biomas e outros; b) corpo humano - a ação dos venenos, soros, primeiros socorros e outros; c) estudo dos animais - características, importância e outros.

A modalidade minicurso foi selecionada porque o ano letivo já estava encaminhado, sendo assim não foi possível incluir no planejamento a unidade didática em questão, no entanto salienta-se que esta pode ser incluída nas aulas regulares, desde que seja previamente programada. 


\subsection{Procedimentos de Construção de Dados}

Essa etapa consistiu em duas fases distintas. Inicialmente, foi realizada uma análise do material de Brito (2002) no intuito de explicitar os possíveis conteúdos procedimentais e atitudinais que podem ser desenvolvidos/demonstrados com a aplicação do mesmo, conforme os pressupostos de Pozo e Crespo (2009). Após essa fase, foi efetuada a construção de uma unidade didática baseada na análise realizada, em parceria com os bolsistas de iniciação a docência do PIBID de Ciências Naturais (ao longo do trabalho esses bolsistas serão identificados como pibidianos)

\subsubsection{A Análise do Material "O Veneno do Saber - Construindo Conhecimento no Serpentário do Jardim Zoológico de Brasília”}

O material "O Veneno do Saber - Construindo Conhecimento no Serpentário do Jardim Zoológico de Brasília" é um recurso pedagógico proposto por (BRITO, 2012), mestre do Programa de Pós-Graduação em Ensino de Ciências (PPGEC), baseado na Teoria da Desequilibração de Jean Piaget que possui a finalidade de subsidiar o docente nas suas ações, fornecendo sugestões metodológicas para que os aprendizes desenvolvam as etapas do conhecimento científico, como: observação, seleção de informações, registro e análise de dados e comunicação, por meio de uma visita mediada no Serpentário do Jardim Zoológico de Brasília - DF, visando à construção do conhecimento sobre o grupo das serpentes (BRITO, 2012).

O material didático conta com seis atividades constituídas de questões investigativas que têm o propósito de fazer com que os educandos atuem ativamente no processo de ensino aprendizagem desde as etapas de elaboração dos bilhetes até a execução e o retorno da saída, considerando as suas ideias prévias, fomentando uma visita dialogada, possibilitando ainda a construção de inúmeras reflexões sobre o tema em estudo (BRITO, 2012). Essas tarefas são dispostas em sequências, mas estas podem ser utilizadas em sala de aula independentemente dessa organização, conforme expõe Brito (2012).

Como o recurso não envolve uma proposta voltada para o desenvolvimento/demonstração da natureza procedimental e atitudinal elencou-se a 
possibilidade de uso de cada atividade, conforme a sequência explicitada no material, para a construção dos mesmos, baseados na categorização dos procedimentos (aquisição, interpretação, análise e inferências, compreensão e organização e comunicação da informação) e das atitudes (em respeito à ciência, em respeito à aprendizagem da ciência e em respeito às implicações sociais da ciência), expostas por Pozo e Crespo (2009). Dessa forma, nas tabelas abaixo, são apresentados os possíveis conteúdos procedimentais e atitudinais a serem desenvolvidos/demonstrados nos educandos por meio da efetivação das tarefas do material de Brito (2012), mediante a análise realizada embasada nas contribuições de Pozo e Crespo (2009).

\section{1- Nos Bastidores da Visita: Preparando a Atividade}

$\mathrm{Na}$ primeira atividade, sugere-se que os aprendizes elaborem instrumentos que torne possível a visitação ao Zoo, como o documento de autorização e o agendamento do transporte de ida ao Zoológico. A questão investigativa que norteia essa etapa é a seguinte: “Onde estou? Para onde vou?". Assim, espera-se que os educandos busquem artifícios (internet, mapas, rotas e outros) para determinar a distância da escola até o espaço não formal, solicitando que ocorra um debate para a apresentação dos valores encontrados (BRITO, 2012).

Com a aplicação dessa etapa, mediante a análise, espera-se que ocorra a desenvolvimento/demonstração dos seguintes conteúdos nos educandos (Tabela 3): 
Tabela 3 - Categoria dos possíveis conteúdos procedimentais e atitudinais que podem ser inseridos com a atividade "Nos bastidores: Preparando a Visita".

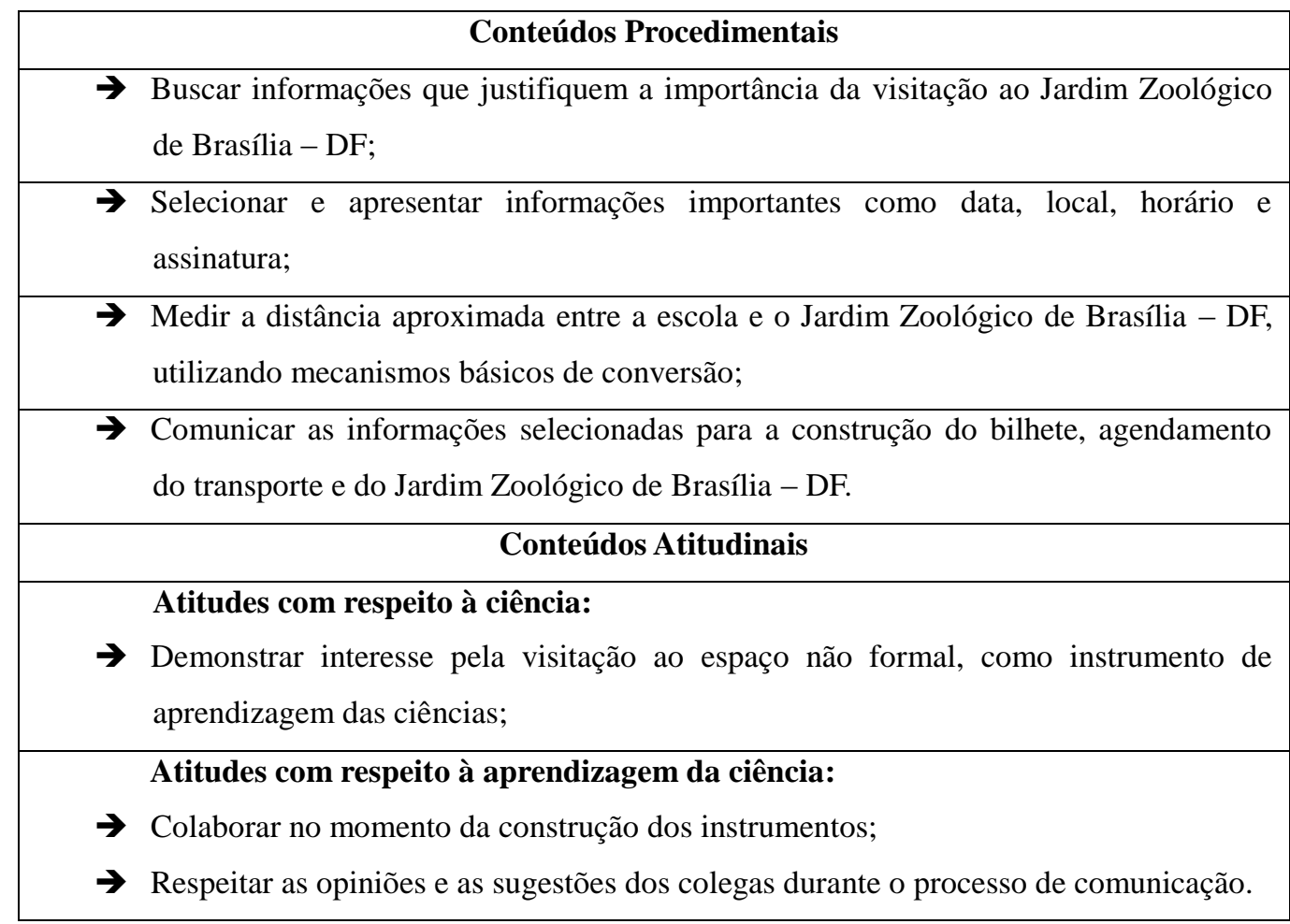

\section{2- Um Pouco da História do Jardim Zoológico de Brasília}

Nessa atividade, é apresentada a história do Jardim Zoológico de Brasília, explicitando o motivo da sua construção, a importância e o local de onde animais são retirados. As questões investigativas que norteiam essa etapa são as seguintes: "Por que se torna inviável a soltura dos animais que estão em cativeiro em seus habitats naturais? Quais são os impactos ambientais que podem ser causados pela soltura de animais exóticos?" Com essas indagações, espera-se os aprendizes utilizem ferramentas de pesquisas para responder a essas inquietações (BRITO, 2012).

Além do mais, recomenda-se também que o docente apresente uma fotografia, que está presente no próprio material, que retrata o primeiro caso de nascimentos de filhotes de onças pintadas do Zoológico de Brasília, estimulando os aprendizes a realizarem uma reflexão crítica acerca das dificuldades e empecilhos que os profissionais encontram no cotidiano para conseguir reproduzir algumas espécies nesse ambiente (BRITO, 2012).

Analisando esta tarefa, pode-se desenvolver/demonstrar os seguintes conteúdos (Tabela 4): 
Tabela 4 - Categoria dos possíveis conteúdos procedimentais e atitudinais que podem ser inseridos com a atividade "Um Pouco da História do Jardim Zoológico de Brasília".

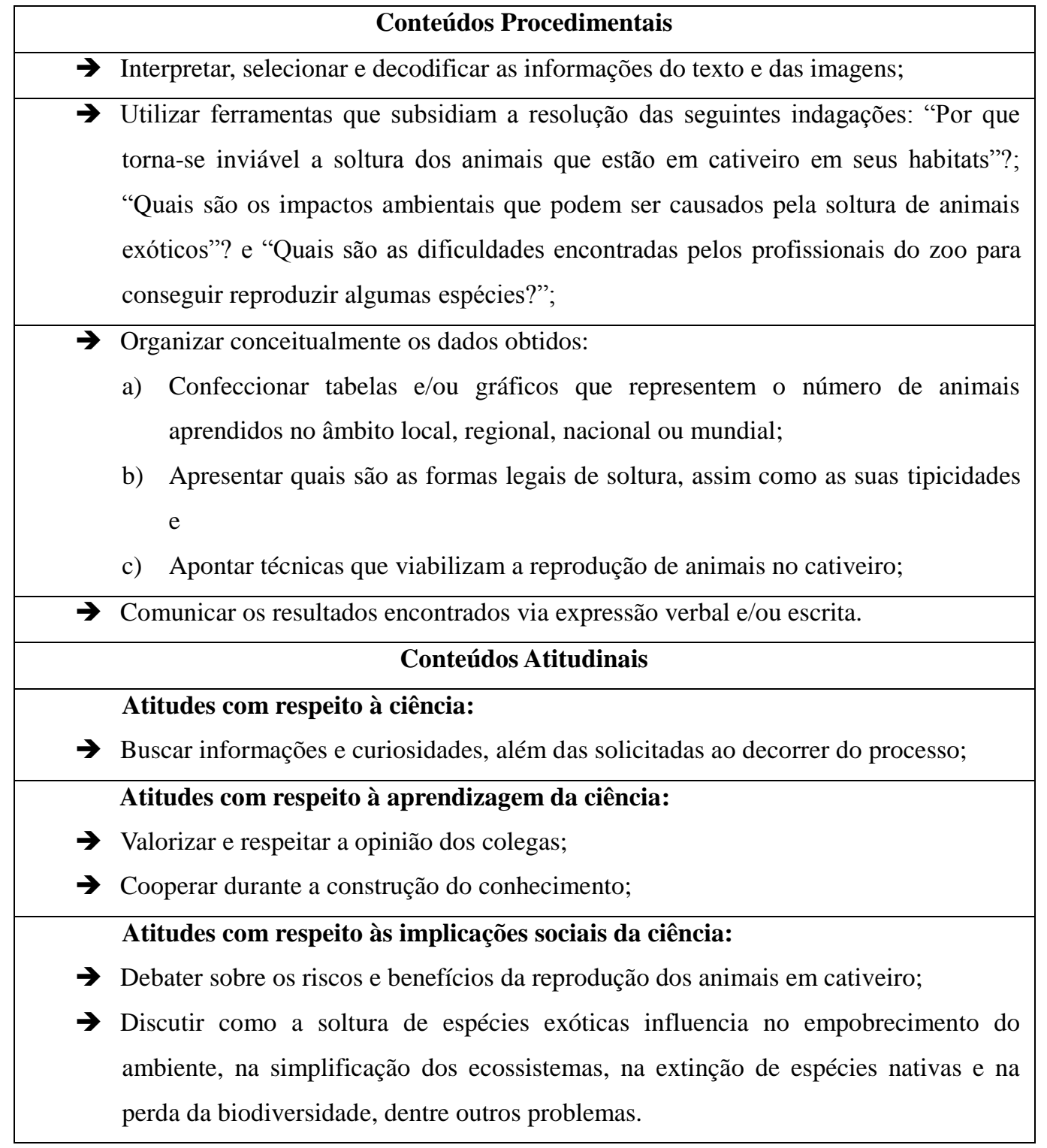

\section{3- Curiosidades e Atitudes que Marcaram o Zoológico de Brasília}

Nessa atividade proposta, indica-se que sejam apresentados contos acerca da Elefanta Nely e dos macacos Capitu e Eliseu, animais que marcaram a história do Zoo-DF. Dessa forma, sabendo que seres vivos que são utilizados em apresentações circenses, geralmente, sofrem maus tratos, solicita-se que os aprendizes investiguem durante a visitação, essa temática com o núcleo responsável pelo condicionamento desses seres vivos, buscando averiguar como funciona esse processo (BRITO, 2012). 
Assim, por meio da análise, explicita-se que é possível o desenvolvimento/demonstração dos seguintes conteúdos (Tabela 5):

Tabela 5 - Categoria dos possíveis conteúdos procedimentais e atitudinais que podem ser inseridos com a atividade "Curiosidades e Atitudes que marcaram o Zoológico de Brasília".

\begin{tabular}{|c|}
\hline Conteúdos Procedimentais \\
\hline $\begin{array}{l}\rightarrow \text { Investigar, durante a saída de campo, como se dá o processo de condicionamento dos } \\
\text { animais que chegam ao zoológico; }\end{array}$ \\
\hline$\rightarrow$ Registrar os dados encontrados; \\
\hline$\rightarrow$ Organizar conceitualmente as informações obtidas; \\
\hline$\rightarrow$ Elucidar os resultados encontrados via expressão verbal e/ou escrita. \\
\hline Conteúdos Atitudinais \\
\hline $\begin{array}{l}\text { Atitudes com respeito à ciência: } \\
\rightarrow \text { Demonstrar interesse e motivação para compreender a importância do processo de } \\
\text { condicionamento; }\end{array}$ \\
\hline $\begin{aligned} & \text { Atitudes com respeito à aprendizagem da ciência: } \\
\rightarrow & \text { Contribuir com as ideias impostas pelos colegas; } \\
\rightarrow & \text { Cooperar durante a construção e a comunicação do conhecimento; }\end{aligned}$ \\
\hline $\begin{array}{ll} & \text { Atitudes com respeito às implicações sociais da ciência: } \\
\rightarrow & \text { Debater sobre a responsabilidade do núcleo de condicionamento do zoo ao receber os } \\
& \text { animais vítimas de maus tratos; } \\
\rightarrow & \text { Apresentar criticamente casos de mau condicionamento e falta de cuidados com os } \\
\text { animais de zoos; } & \text { Elucidar formas de abrigar e cuidar bem dos animais. }\end{array}$ \\
\hline
\end{tabular}

\section{4- Localização, Organização e Alguns Dados do Zoo}

Essa etapa consiste na apresentação e discussão de alguns dados referentes à localização, área e atividades realizadas no Jardim Zoológico de Brasília - DF. Tais informações são elucidadas por meio de um texto corriqueiro e imagens de diversos mapas (BRITO, 2012).

Com a análise efetuada, evidencia-se que podem ser desenvolvidos/demonstrados os seguintes conteúdos (Tabela 6): 
Tabela 6 - Categoria dos possíveis conteúdos procedimentais e atitudinais que podem ser inseridos com a atividade "Localização, Organização e alguns Dados do Zoológico de Brasília - DF”.

\begin{tabular}{|ll|}
\hline \multicolumn{1}{|c|}{ Conteúdos Procedimentais } \\
\hline$\rightarrow$ & Interpretar, selecionar e decodificar as informações do texto e das imagens; \\
\hline$\rightarrow$ & Organizar conceitualmente as informações obtidas; \\
\hline$\rightarrow$ & Comunicar os resultados encontrados via expressão verbal e/ou escrita. \\
\hline \multicolumn{1}{c|}{ Conteúdos Atitudinais } \\
\hline & Atitudes com respeito à ciência: \\
$\rightarrow$ & Demonstrar interesse para compreender a estrutura, importância e localização do \\
& Jardim Zoológico de Brasília - DF; \\
& Atitudes com respeito à aprendizagem da ciência: \\
$\rightarrow$ & Apreciar e aceitar a opinião dos colegas; \\
$\rightarrow$ & Colaborar perante a atividade proposta; \\
& Atitudes com respeito às implicações sociais da ciência: \\
$\rightarrow$ & Debater sobre a função do Jardim Zoológico de Brasília - DF.
\end{tabular}

\section{5- O Serpentário}

Na visitação ao Zoológico de Brasília-DF, é recomendado que o foco de observação seja o serpentário, espaço no qual abriga diversas espécies de serpentes. Tal local foi selecionado, devido às diversas sensações (simpatia, medo, repulsa e outros) que os indivíduos fornecem quando estão em contato com esses animais. Nessa etapa, existem diversas questões investigativas para nortear a atividade (BRITO, 2012).

Inicialmente, é proposto que os aprendizes observem e desenhem as diferenças encontradas na cabeça das serpentes e façam uma relação das mesmas com a peçonha, utilizando livros didáticos e as plaquinhas presentes no serpentário como fonte de pesquisa (BRITO, 2012).

Assim, com a análise realizada, verificou-se que os seguintes conteúdos podem ser desenvolvidos/demonstrados (Tabela 7): 
Tabela 7 - Categoria dos possíveis conteúdos procedimentais e atitudinais que podem ser inseridos com a atividade "Nem sempre o que parece é! Resíduos da Colonização".

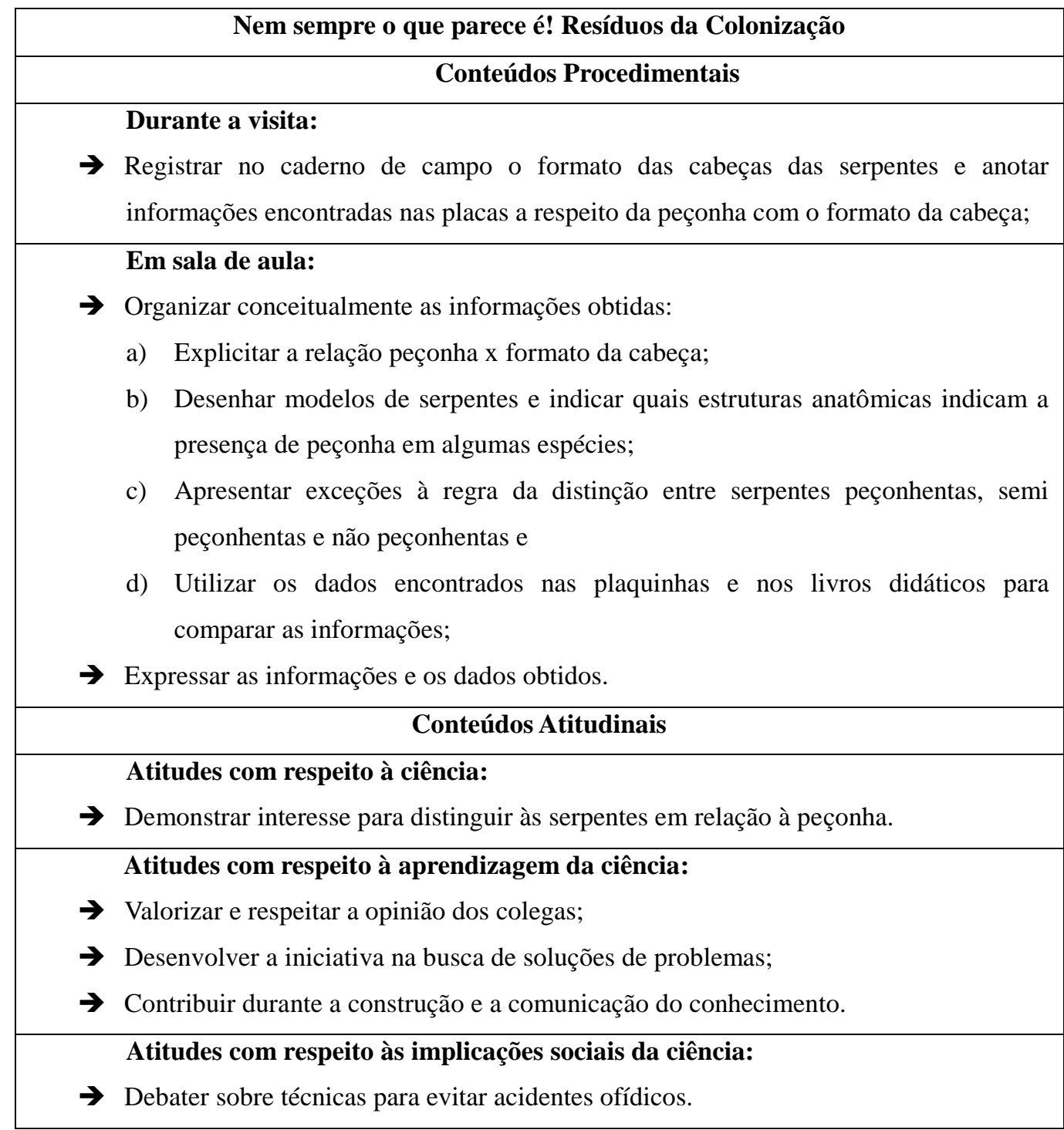

Com relação à quantidade de anéis presentes nas cascavéis, propõe-se averiguar as percepções prévias dos alunos no que tange essa questão e, após a visita, solicitar que os mesmos realizem uma pesquisa bibliográfica, a fim de discutir como o ambiente interfere na muda das serpentes (BRITO, 2012).

Dessa forma, por meio da análise instaurada, infere-se que tal atividade pode desenvolver/demonstrar os seguintes procedimentos (Tabela 8): 
Tabela 8 - Categoria dos possíveis conteúdos procedimentais e atitudinais que podem ser inseridos com a atividade "Anéis do tempo: o número de anéis do chocalho da cascavel indica a idade do animal?".

\begin{tabular}{|c|}
\hline $\begin{array}{c}\text { Anéis do tempo: o número de anéis do chocalho da cascavel indica a idade do animal? } \\
\text { Conteúdos Procedimentais }\end{array}$ \\
\hline $\begin{array}{l}\text { Antes da visita: } \\
\rightarrow \text { Formular hipóteses que expliquem o porquê das cascavéis apresentarem quantidades } \\
\text { diferentes de anéis. }\end{array}$ \\
\hline $\begin{array}{l}\text { Durante a visita: } \\
\rightarrow \text { Identificar as cascavéis; } \\
\rightarrow \text { Observar os chocalhos; } \\
\rightarrow \text { Desenhar modelos explicitando a quantidade de anéis presentes em algumas } \\
\text { cascavéis; }\end{array}$ \\
\hline $\begin{array}{l}\text { Após a visita: } \\
\rightarrow \text { Realizar pesquisa bibliográfica a respeito do processo de muda, elucidando: } \\
\text { a) Quais mecanismos as serpentes utilizam para trocar a pele; } \\
\text { b) Fatores que influenciam no processo de troca; } \\
\text { c) Problemas nas trocas; } \\
\rightarrow \text { Comunicar acerca das informações obtidas. }\end{array}$ \\
\hline Conteúdos Atitudinais \\
\hline $\begin{array}{l}\text { Atitudes com respeito à ciência: } \\
\rightarrow \text { Diferenciar senso comum do conhecimento científico com relação à questão dos } \\
\text { anéis. }\end{array}$ \\
\hline $\begin{aligned} & \text { Atitudes com respeito à aprendizagem da ciência: } \\
\rightarrow & \text { Respeitar a opinião dos colegas; } \\
\rightarrow & \text { Desenvolver a iniciativa na busca de soluções de problemas; } \\
\rightarrow & \text { Cooperar durante a construção e a comunicação do conhecimento. }\end{aligned}$ \\
\hline
\end{tabular}

Para abordar acerca das características gerais das serpentes, os hábitos alimentares e o processo de digestão, recomenda-se que seja realizada uma pesquisa com a finalidade de discutir sobre esses assuntos em sala de aula. Dessa forma, após a discussão, e durante a exposição, sugere-se que sejam realizadas anotações referentes à alimentação, construindo uma cadeia alimentar (BRITO, 2012).

Assim, por meio da analise, evidencia-se a possibilidade de desenvolver/demonstrar tais conteúdos (Tabela 9): 
Tabela 9 - Categoria dos possíveis conteúdos procedimentais e atitudinais que podem ser inseridos com a atividade "Percebendo o ambiente que me cerca!".

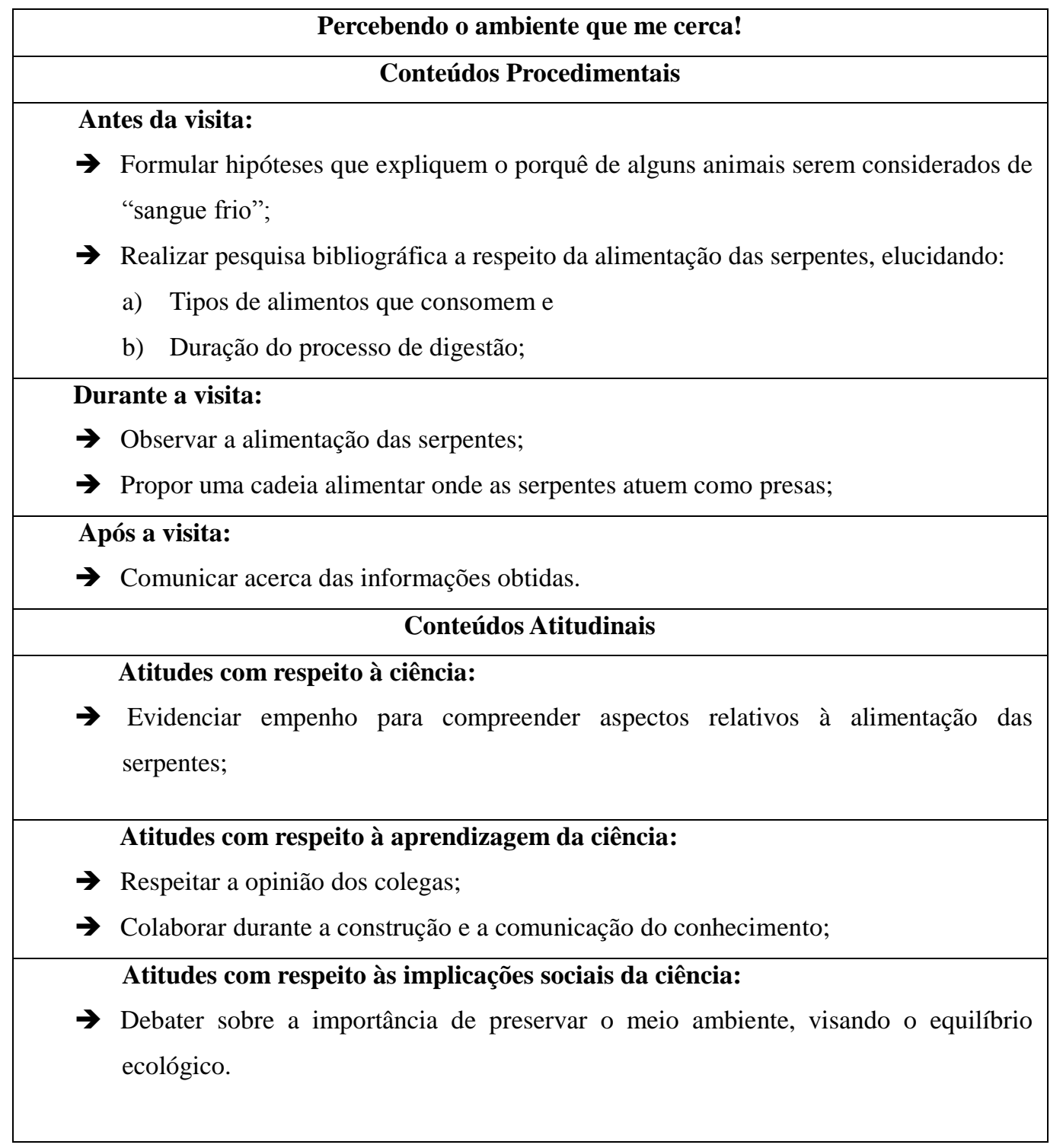

Outra sugestão é observar a relação entre o formato das pupilas das serpentes e suas respectivas atividades, utilizando como instrumento as placas informativas. Dessa forma, mediante a análise, elenca-se a capacidade dessa proposta desenvolver/demonstrar os seguintes conteúdos (Tabela 10): 
Tabela 10 - Categoria dos possíveis conteúdos procedimentais e atitudinais que podem ser inseridos com a atividade "Olho nos Olhos: a Relação entre o Formato da Pupila e as Atividades do Animal".

\begin{tabular}{|c|}
\hline $\begin{array}{c}\text { Olho nos Olhos: a Relação entre o Formato da Pupila e as Atividades do Animal. } \\
\text { Conteúdos Procedimentais }\end{array}$ \\
\hline $\begin{array}{l}\text { Durante a visita: } \\
\rightarrow \text { Observar o formato da pupila das serpentes; } \\
\rightarrow \text { Desenhar as pupilas das serpentes; } \\
\rightarrow \text { Registrar o horário das atividades das serpentes que são encontrados nas placas } \\
\text { informativas; }\end{array}$ \\
\hline $\begin{array}{l}\text { Após a visita: } \\
\rightarrow \text { Estabelecer relações entre formato da pupila e período em que desenvolvem suas } \\
\text { atividades; } \\
\rightarrow \text { Comunicar acerca das informações obtidas. }\end{array}$ \\
\hline Conteúdos Atitudinais \\
\hline $\begin{aligned} & \text { Atitudes com respeito à ciência: } \\
\rightarrow & \text { Mostrar interesse para relacionar horários de atividade e formato da pupila; } \\
\rightarrow & \text { Dialogar acerca da importância das serpentes para o equilíbrio ecológico; }\end{aligned}$ \\
\hline $\begin{aligned} & \text { Atitudes com respeito à aprendizagem da ciência: } \\
\rightarrow & \text { Respeitar a opinião dos colegas; } \\
\rightarrow & \text { Mobilizar para a de soluções de problemas; } \\
\rightarrow & \text { Colaborar durante o intercâmbio de comunicações. }\end{aligned}$ \\
\hline
\end{tabular}

Para tratar do tema acidente ofídicos, é proposto que os aprendizes estabeleçam limites acerca das serpentes peçonhentas, semi peçonhentas e não peçonhentas que estão abrigadas no serpentário, discutindo a importância da classificação em ciências.

Logo, ao analisar essa tarefa, evidencia-se que podem ser desenvolvidos/demonstrados os seguintes conteúdos (Tabela 11): 
Tabela 11 - Categoria dos possíveis conteúdos procedimentais e atitudinais que podem ser inseridos com a atividade "Nem tudo que Rasteja é Réptil! Classificando as Serpentes".

\begin{tabular}{|c|}
\hline Nem tudo que Rasteja é Réptil! Classificando as Serpentes. \\
\hline Conteúdos Procedimentais \\
\hline $\begin{array}{l}\text { Durante a visita: } \\
\rightarrow \text { Observar as serpentes que estão dispostas em duas categorias (peçonhentas e semi } \\
\quad \text { peçonhentas e não peçonhentas); } \\
\rightarrow \text { Estabelecer limites que separam os dois grupos; } \\
\rightarrow \text { Criar novos padrões de classificação; }\end{array}$ \\
\hline $\begin{array}{l}\text { Após a visita: } \\
\rightarrow \text { Discutir acerca das exceções existentes; } \\
\rightarrow \text { Dispor em gráfico e/ou tabela os resultados encontrados; } \\
\rightarrow \text { Comunicar os padrões de classificação construídos. }\end{array}$ \\
\hline Conteúdos Atitudinais \\
\hline $\begin{aligned} & \text { Atitudes com respeito à ciência: } \\
\rightarrow & \text { Compreender as dificuldades e necessidades de classificar em ciências. }\end{aligned}$ \\
\hline $\begin{aligned} & \text { Atitudes com respeito à aprendizagem da ciência: } \\
\rightarrow & \text { Respeitar as ideias dos colegas; } \\
\rightarrow & \text { Desenvolver a iniciativa para problemas; } \\
\rightarrow & \text { Participar ativamente da comunicação do conhecimento; }\end{aligned}$ \\
\hline
\end{tabular}

Além do mais, recomenda-se que os discentes façam uma pesquisa a fim de coletar dados de acidentes ofídicos que aconteceram no âmbito local, regional, nacional ou global, assim como o local da picada e o tipo de ambiente. Nesse momento, ressalta-se que é importante discutir sobre o motivo pelo qual as serpentes atacam outros seres.

Por meio da análise, ressalta-se que tais conteúdos podem ser desenvolvidos/demonstrados (Tabela 12): 
Tabela 12 - Categoria dos possíveis conteúdos procedimentais e atitudinais que podem ser inseridos com a atividade “Tira esse Ofídio do Caminho, que eu Quero Passar com meu Trator! Por que as Serpentes Atacam?”.

\begin{tabular}{|c|}
\hline $\begin{array}{c}\text { Tira esse Ofídio do Caminho, que eu Quero Passar com meu Trator! Por que as } \\
\text { Serpentes Atacam? }\end{array}$ \\
\hline Conteúdos Procedimentais \\
\hline $\begin{array}{l}\rightarrow \text { Realizar uma pesquisa acerca do número de acidentes ofídicos, locais de ocorrência, } \\
\text { partes atingidas e tipos de serpentes; } \\
\rightarrow \text { Definir o âmbito das informações: local, regional, nacional e mundial; } \\
\rightarrow \text { Construir instrumentos (tabelas, gráficos, cartazes e outros) para expor os dados } \\
\text { encontrados; } \\
\rightarrow \text { Comunicar os resultados obtidos. }\end{array}$ \\
\hline Conteúdos Atitudinais \\
\hline $\begin{aligned} & \text { Atitudes com respeito à ciência: } \\
\rightarrow & \text { Apresentar organização dos dados; } \\
\rightarrow & \text { Respeito pelo grupo das serpentes; } \\
\rightarrow & \text { Mostrar-se crítico perante o antropocentrismo e a visão utilitarista do homem. }\end{aligned}$ \\
\hline $\begin{aligned} & \text { Atitudes com respeito à aprendizagem da ciência: } \\
\rightarrow & \text { Valorizar e respeitar a opinião dos colegas; } \\
\rightarrow & \text { Buscar de soluções para inquietações; } \\
\rightarrow & \text { Cooperar durante as discussões; }\end{aligned}$ \\
\hline $\begin{aligned} & \text { Atitudes com respeito às implicações sociais da ciência: } \\
& \rightarrow \text { Discutir sobre como o homem interfere na reducão das sernentes. }\end{aligned}$ \\
\hline
\end{tabular}

\section{6- No Espaço Formal - Concluindo a Atividade}

Na etapa final, é proposta a socialização dos saberes por meio da confecção de diversos recursos didáticos como: vídeos, fotografias, painéis, banners, seminários, dentre outros, acerca do conhecimento construído durante as atividades.

Ao analisar tal proposta, demonstra-se que com essa atividade podem-se desenvolver/demonstrar os seguintes conteúdos (Tabela 13): 
Tabela 13 - Categoria dos possíveis conteúdos procedimentais e atitudinais que podem ser inseridos com a atividade "No espaço Formal - Concluindo a Atividade".

\begin{tabular}{|c|}
\hline Conteúdos Procedimentais \\
\hline $\begin{array}{l}\rightarrow \text { Interpretar, selecionar e decodificar as informações construídas durante a aplicação } \\
\text { das atividades; }\end{array}$ \\
\hline$\rightarrow$ Organizar conceitualmente as informações obtidas; \\
\hline $\begin{array}{l}\rightarrow \text { Comunicar os resultados encontrados utilizando diversos recursos como: vídeos, feira } \\
\text { de ciências, painéis, modelos, histórias, dentre outros. }\end{array}$ \\
\hline Conteúdos Atitudinais \\
\hline $\begin{aligned} & \text { Atitudes com respeito à ciência: } \\
\rightarrow & \text { Demonstrar interesse pela comunicação do saber socialmente construído; }\end{aligned}$ \\
\hline $\begin{aligned} & \text { Atitudes com respeito à aprendizagem da ciência: } \\
\rightarrow & \text { Valorizar e respeitar a opinião dos colegas; } \\
\rightarrow & \text { Cooperar durante a construção e a comunicação do conhecimento; }\end{aligned}$ \\
\hline
\end{tabular}

Nesse sentido, ressalta-se que "estabelecer critérios de conteúdos atitudinais e procedimentais no ensino de determinado tema não limita a abrangência desses conteúdos, mas os inclui no currículo e possibilita ao professor registrar e prever a aquisição dos mesmos aliados às estratégias de ensino" (GUIMARÃES; FALCOMER, 2013, p. 2295). Assim, cabe salientar que o docente tem liberdade para utilizar o material didático sobre serpentes, conforme as especificidades e necessidades do contexto no qual está inserido (BRITO, 2012).

\subsubsection{Processo de Construção e Aplicação da Unidade Didática}

Realizada a análise do recurso proposto por Brito (2012), foi construída uma proposição didática baseada nas sugestões e nas atividades contidas nesse material. Para que a unidade didática fosse elaborada, ocorreram reuniões semanais durante o período de um mês com os cinco licenciandos do PIBID.

O PIBID é um projeto nacional voltado para a formação colaborativa de professores, uma vez que estudantes de graduação (bolsistas de iniciação a docência) desenvolvem atividades didático-pedagógicas em parceria com o professor da educação básica de uma escola pública (supervisor), sob a orientação de professores de uma Instituição de Ensino Superior (coordenadores) (CAPES, 2015). 
Os objetivos prioritários do PIBID envolvem: a) viabilizar a valorização da docência; b) aperfeiçoar a formação inicial dos educadores, em parceria com a educação básica e superior; c) inserir licenciandos no contexto escolar, oferecendo a oportunidade de criar ações educativas e conhecer melhor esse espaço; d) oportunizar que os professores de educação básica participem da formação de novos educadores e e) favorecer a articulação entre teoria e prática, com a finalidade de melhorar a educação básica (CAPES, 2015).

O PIBID de Ciências Naturais possui uma proposta voltada para momentos de coordenação e regência. Dessa forma, os bolsistas juntamente com os coordenadores e a supervisora são responsáveis pelo planejamento das atividades a serem implementadas nas aulas de Ciências Naturais. As atividades envoltas nesse PIBID propõe a inserção de intervenções no meio educativo, com o auxílio de estratégias e recursos didáticos diferenciados, como: modelos, jogos, animações, histórias em quadrinhos, experimentos e outros no intuito de (re) significar as aulas de ciências e formar indivíduos mais ativos, reflexivos e críticos perante o meio no qual vivem e desenvolvem seu papel de cidadão.

Assim, para construir a unidade didática, que foi aplicada no âmbito escolar e no Jardim Zoológico de Brasília-DF, foram realizadas quatro reuniões, na própria escola, entre o grupo de planejamento (a professora supervisora e os licenciandos do PIBID) para efetuar a leitura das atividades propostas no material de Brito (2012) e da análise dos possíveis conteúdos atitudinais e procedimentais que tais tarefas poderiam desenvolver/demonstrar nos alunos.

$\mathrm{Na}$ primeira reunião, houve uma discussão para elencar estratégias para tornar as atividades da unidade didática, baseada no material de Brito (2012), com caráter mais aberto, no intuito de propor um material direcionado para o âmbito investigativo, considerando que problemas qualitativos são instrumentos eficazes para a aprendizagem, pois: a) promovem discussões em grupo; b) possibilitam a expressão de ideias e reflexão sobre elas; c) permitem o conhecimento de diferentes interpretações e soluções para uma mesma questão e d) auxiliam no estabelecimento das relações entre o conhecimento científico e pessoal (POZO; CRESPO, 2009).

Como o material é proposto para que o (a) educador (a) possa aplicar tal recurso em sala de aula, ou em outra modalidade também, foram estabelecidos pelo grupo de planejamento alguns quesitos para serem explicitados na unidade didática, no intuito de esclarecer o objetivo de cada atividade e facilitar a compreensão para a inserção do mesmo. 
Assim, cada tarefa descrita, possui os seguintes itens: tema, público-alvo, duração, objetivos, metodologia, recursos e avaliação. Nesse encontro, foram confeccionadas as seguintes atividades:

a) Investigazoo: problematizando com os estudantes sobre o Zoológico/Serpentário de Brasília-DF - consiste na aplicação de um jogo didático-pedagógico para verificar os conhecimentos prévios dos discentes acerca do Jardim Zoológico de Brasília e sobre questões gerais que envolvem a temática de serpentes.

b) Explorando um pouco da história do Jardim Zoológico de Brasília-DF - envolve a leitura de um texto voltado para a história do Zoo de Brasília-DF e a discussão de uma questão investigativa acerca dos possíveis impactos causados pela soltura de animais exóticos em ambientes naturais.

c) Buscazoo: Avaliando a Situação Atual do Zoo de Brasília-DF - trata-se da busca e comunicação de informações recentes a respeito do espaço não formal nos meios eletrônicos.

A primeira atividade descrita não estava presente no material proposto por Brito (2012), no entanto surgiu a necessidade de inseri-la para averiguar as concepções prévias dos estudantes. Essa sugestão foi retirada em partes da unidade didática proposta por Souto (2013). Cabe ressaltar que Brito (2012) expõe que o material não é uma forma acabada e completa para trabalhar o ensino de serpentes, mas que o educador pode criar novas questões conforme for o interesse e a necessidade.

$\mathrm{Na}$ segunda reunião, foram realizadas novas leituras do material de Brito (2012) e confeccionadas e adaptadas mais quatro atividades:

a) Appzoo: Conhecendo o Zoo de Brasília-DF - essa atividade consiste na coleta de informações a partir da manipulação do ZooMapsBrasília, um aplicativo que retrata informações sobre as áreas do Zoo, a localização e os animais presentes nesse ambiente.

b) Discutindo sobre a Importância das Serpentes - promove a discussão com os familiares a respeito da importância das serpentes e a comunicação da informação.

c) Atividade Prática: Conhecendo as Cascáveis - permite que os aprendizes visualizem amostras de cascavéis (Crotalus durissus) e estudem sua estrutura anatômica. 
d) Agendazoo: Marcando a Visita ao Zoo -DF - possibilita que os discentes tenham a oportunidade de construir um bilhete solicitando o agendamento do ônibus e a autorização dos responsáveis para a ida ao passeio educativo.

Essas reuniões promoveram grandes momentos de rica aprendizagem e diálogo, pois sempre havia discussão no intuito de tornar as atividades cada vez mais investigativas, permitindo despertar o interesse e a motivação dos discentes para a solução de problemas.

Na penúltima reunião, foram elaboradas as últimas atividades:

a) Localização: Ida ao Zoo de Brasília - DF - busca promover a construção de um mapa de ida ao serpentário, demonstrando pontos de referência, rotas e escalas.

b) Visitando o Serpentário do Zoo de Brasília-DF - essa atividade é pertinente à ida ao serpentário no intuito de utilizar esse espaço como instrumento para a resolução de problemas levantados no decorrer das outras atividades. Também houve no espaço formal, a comunicação das informações obtidas por meio dessa visitação educativa.

c) Serpentes: Amigas ou Inimigas?- consiste na discussão acerca dos acidentes ofídicos, por meio de histórias em quadrinhos, confeccionadas por um pibidiano, e na realização de entrevistas com os pais a respeito do assunto em questão.

d) Comunicando o Conhecimento no Espaço Escolar - essa tarefa envolve a construção de materiais pelos aprendizes, para que os mesmos possam comunicar para a comunidade escolar os conhecimentos adquiridos com as atividades realizadas nos encontros.

Para finalizar a construção da unidade didática, foi elaborado um glossário a fim de auxiliar o leitor na compreensão de alguns termos voltados para a herpetologia e conceitos específicos da área de ensino.

Após a confecção do material didático, houve uma sistematização das atividades que seriam aplicadas em cada encontro do minicurso (Tabela 14). Para organizar tais tarefas, a cada semana ocorria uma reunião na Faculdade UnB de Planaltina-DF entre o grupo de planejamento para discutir estratégias e separar materiais para a efetivação dos encontros marcados. Dessa forma, ficou definido que a cada semana dois licenciandos aplicariam as atividades previstas e o outro faria a etapa de observação, conforme a disponibilidade dos mesmos para ministrar/observar o encontro do minicurso. Assim, tais atividades foram aplicadas no horário contrário da aula regular, onde cada encontro teve a duração média de 3 
horas, totalizando aproximadamente 24 horas de minicurso. Esses encontros ocorreram em vários espaços da escola: sala de artes, videoteca e área verde, dependendo da disponibilidade do local.

Tabela 14- Organização das atividades desenvolvidas em cada encontro.

\begin{tabular}{|c|l|}
\hline \multicolumn{1}{|c|}{ Data } & \multicolumn{1}{c|}{ Atividades } \\
\hline $13 / 08 / 2015$ & $\begin{array}{l}\text { Investigazoo: problematizando com os estudantes sobre o } \\
\text { Zoológico/Serpentário } \\
\text { Explorando um pouco da história do Jardim Zoológico de Brasília- } \\
\text { DF } \\
\text { Buscazoo: Avaliando a Situação Atual do Zoo de Brasília-DF }\end{array}$ \\
\hline $20 / 08 / 2015$ & $\begin{array}{l}\text { Buscazoo: Avaliando a Situação Atual do Zoo de Brasília-DF } \\
\text { Appzoo: Conhecendo o Zoo de Brasília-DF } \\
\text { Localização: Ida ao Zoo de Brasília - DF }\end{array}$ \\
\hline $27 / 08 / 2015$ & $\begin{array}{l}\text { Agendazoo: Marcando a Visita ao Zoo -DF } \\
\text { Discutindo sobre a Importância das Serpentes }\end{array}$ \\
\hline $02 / 09 / 2015$ & Atividade Prática: Conhecendo as Cascáveis \\
\hline $10 / 09 / 2015$ & Visitando o Serpentário do Zoo de Brasília-DF \\
\hline $16 / 09 / 2015$ & Serpentes: Amigas ou Inimigas? \\
\hline $25 / 09 / 2015$ & Organização da feira de Ciências \\
\hline $12 / 12 / 2015$ & Comunicando o Conhecimento no Espaço Escolar \\
\hline
\end{tabular}

\subsection{Processo de Coleta de Dados}

Para coletar os dados adquiridos por meio da aplicação do minicurso, que foi implementado no espaço escolar e no serpentário do Zoo de Brasília-DF, foram utilizados três instrumentos diferentes: a) diário de campo - era um caderno que foi entregue para os aprendizes participantes do minicurso. Este material propiciou a anotação de dados, informações e procedimentos acerca da temática de serpentes, durante a aplicação de toda a unidade didática. Os estudantes utilizaram o mesmo para registrar questões e curiosidades, anexar pesquisas e desenhos, dentre outras finalidades; b) relatórios construídos por meio do processo de observação - nesses instrumentos os licenciandos do PIBID, tanto os mediadores quanto o observador, e a professora supervisora, registravam as atuações dos aprendizes, se o encontro tinha alcançado os objetivos propostos, fatos que marcaram, mudanças atitudinais que ocorreram, dentre outros aspectos. Os observadores iam registrando dados no momento do encontro e depois redigiam um documento, já os mediadores também construíam relatórios, mas em um período posterior. Não houve a elaboração de relatórios pelos 
pibidianos no último encontro, referente à etapa de execução da feira de ciências, devido à falta de disponibilidade dos mesmos para participar da atividade. A construção dos relatórios em questão, foi dada pela observação, considerando a relevância desse meio, uma vez que essa técnica propicia o recolhimento de informações desejadas, utilizando os sentidos (audição e visão), além de examinar os fatos e/ou fenômenos que se desejam investigar (LAKATOS; MARCONI, 2003) e c) gravações e fotografias - para complementar e fornecer fidedignidade aos dados foram realizadas filmagens e fotografias de todos os encontros do minicurso, pela professora supervisora. Essas filmagens foram extremamente importantes, já que complementaram os registros das observações da professora supervisora e dos pibidianos.

\subsection{Processo de Análise dos Dados}

Após a coleta de dados, propiciada pelos registros do diário de campo, relatórios e filmagens e fotografias, foi realizada uma análise qualitativa dos dados. Para efetuar a organização dos dados e selecionar os conteúdos procedimentais e atitudinais desenvolvidos/ demonstrados com o minicurso, foram seguidos os seguintes métodos: a) diário de campo - os cadernos foram identificados pela seguinte nomenclatura: aluno 1 (A1) ao aluno (A21), após a identificação foram transcritos todos os registros dos alunos em cada encontro para documentos do word e sinalizados nesse os procedimentos e as atitudes que apareciam nas anotações, conforme surgiam em cada encontro; b) relatórios construídos por meio do processo de observação - nos relatos dos pibidianos foram grifados os conteúdos em estudo que aparentemente os educandos manifestaram em cada etapa do minicurso, essas falas receberam seguinte identificação: pibidiano (P1) ao pibidiano (P6) e c) gravações e fotografias - para selecionar as atitudes e os procedimentos desenvolvidos/demonstrados pelos alunos nas gravações, utilizou-se os sentidos (ver e ouvir) e logo foram feitas as transcrições das falas dos aprendizes ou da ação realizada em que apareciam os procedimentos e as atitudes. As fotografias selecionadas também condiziam com o aparecimento de algum desses conteúdos em estudo. Foram utilizadas as mesmas nomenclaturas adotadas nos diários de campo.

Os dados previamente selecionados, ou seja, os procedimentos e as atitudes desenvolvidos/demonstrados nos aprendizes, foram correlacionados a tipologia de conteúdos propostos por Pozo e Crespo (2009) no âmbito procedimental (aquisição, interpretação, 
análise e inferências, compreensão e organização e comunicação da informação) e atitudinal (em respeito à ciência, em respeito à aprendizagem da ciência e em respeito às implicações sociais da ciência) conforme é exposto na (Tabelas 1 e 2).

Para a escrita final dessa pesquisa, elencou-se a possibilidade de apresentar as atitudes e os procedimentos conforme eles iam aparecendo em cada atividade instituída ao decorrer do minicurso, no intuito de evidenciar para o leitor como as estratégias, o processo de mediação e os recursos didáticos foram inseridos ao decorrer dos encontros.

É importante ressaltar que foram selecionados para análise apenas alguns dados, sendo assim, buscou-se destacar para discussão os elementos mais representativos em relação àqueles fornecidos pelos participantes envolvidos na proposta. Sendo estes dados discutidos com as referências teórico-conceituais apresentadas neste estudo (DUARTE, 2014). Em suma, o processo de análise ocorreu da seguinte forma: a) análise dos dados presentes nos diários de campo, relatórios, gravações e fotografias; b) identificação dos tipos de procedimentos e atitudes, conforme a categorização proposta por Pozo e Crespo (2009) (Tabela 1 e 2) e c) seleção dos dados mais representativos para expor na pesquisa.

\section{RESULTADOS E DISCUSSÃO}

Este capítulo foi disposto em dois tópicos. O primeiro está exposto em oito etapas a fim de melhor organizar e clarificar os resultados obtidos em relação aos conteúdos procedimentais e atitudinais desenvolvidos/demonstrados com as estratégias e atividades aplicadas em cada encontro. O segundo tópico apresenta uma síntese dos principais elementos atitudinais e procedimentais desenvolvidos/demonstrados ao decorrer do minicurso.

\subsection{1 - $1^{\circ}$ Encontro (13/08/15) - Conversando sobre o Zoológico de Brasília - DF}

No primeiro encontro do minicurso, as atividades foram ministradas pelos pibidianos $\mathrm{P} 1$ e P3, enquanto o pibidiano $\mathrm{P} 4$ e a professora-pesquisadora observavam e faziam registros das ações dos alunos. 
Nesse momento inicial, foi constatado o desenvolvimento/demonstração de alguns tipos de conteúdos procedimentais e atitudinais, propostos por Pozo e Crespo (2009), segundo a classificação presente nas Tabelas 1 e 2 .

Assim sendo, as atividades propostas para o encontro foram iniciadas pelo pibidiano P1, onde primeiramente o mesmo agradeceu a colaboração e disponibilidade dos aprendizes em participar do minicurso. Após, o pibidiano P3 explicitou para estes a finalidade do diário de campo a ser entregue.

A primeira intervenção que foi implementada diz respeito ao "Jogo Didático Investigazoo" (Figura 1). Esse material possuía como objetivo primordial investigar os conhecimentos prévios dos educandos, por meio de perguntas, tendo em vista que "não é possível iniciar nenhuma aula, nenhum novo tópico, sem procurar saber o que os alunos já conhecem ou como eles entendem as propostas a serem realizadas" (CARVALHO, 2013, p. 2). Zabala (1998) afirma ainda, que é essencial realizar tal exercício para oportunizar a formulação de ideias e hipóteses por parte dos discentes, além de permitir que o docente averigue o grau de envolvimento destes com as questões trabalhadas.

Dessa forma, foi solicitado que os estudantes dividissem-se em equipe entre 5 e 6 componentes. Conforme Roden e Ward (2010), o trabalho em grupo oportuniza que os aprendizes discutam ideias e soluções, reflitam e cooperem entre si, desenvolvendo e adotando posturas científicas por meio dessa organização. No entanto, constatou-se no primeiro instante um pouco de dificuldade na montagem dos grupos. Esse ponto pode ser justificado pela circunstância dos alunos fazerem parte de cinco turmas diferentes.

Após a divisão, o pibidiano P1 entregou as regras do Investigazoo e sugeriu que os mesmos fizessem uma leitura silenciosa. Logo, o pibidiano P3, questionou os participantes acerca das regras e os mesmos debateram sobre esse quesito. Em seguida, foram lançados os dados para decidir qual grupo iniciaria o sorteio das questões presentes no recurso didático em aplicação. Com isso, cada grupo recebeu a pergunta e os integrantes começaram a formular respostas, discutir entre eles e registrar tais dados no diário de campo.

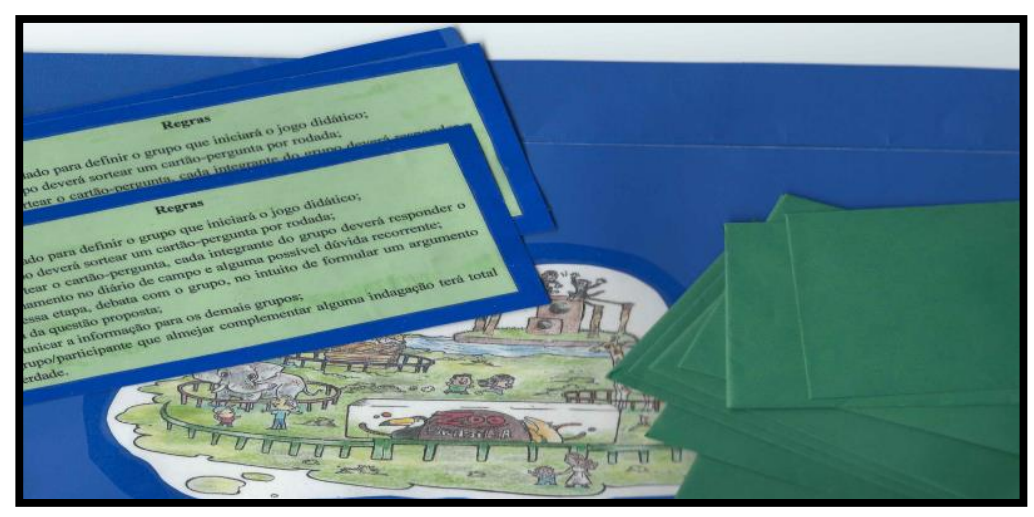

Figura 1 - Jogo Investigazoo: regras e cartas-pergunta. 
Em relação à questão "No Jardim Zoológico, um dos locais disponíveis para visitação é o serpentário. Você já teve a oportunidade de conhecer este espaço? Se sim, como foi? Caso você ainda não tenha ido ao Jardim Zoológico, há alguma curiosidade ou dúvida acerca desse local? Explique.”, o participante A1 expressou na sua fala que:

"Sim, quando eu cheguei a cobra estava trocando de pele." (A1)

Ao explicitar essa indagação, evidencia-se um procedimento em relação à aquisição da informação, uma vez que o mesmo utilizou um dado que foi extraído por meio de uma observação para expressar a informação científica obtida na visitação ao Jardim Zoológico de Brasília-DF. De acordo com Ward e Roden (2010), a observação é uma habilidade processual que pode viabilizar o surgimento de questões e dúvidas por meio dos detalhes observados, instigando os alunos a realizarem novas investigações.

No entanto, outro aluno do mesmo grupo registrou que:

"Não. Curiosidades: eu quero conhecer mais sobre as serpentes e o zoológico, onde tem muitos animais que queria conhecer mais sobre o mundo animal ". ${ }^{1}$ (A8)

Ao serem indagados em outra questão sobre a importância do Zoo, os aprendizes afirmaram que:

"A importância do Jardim Zoológico é que podemos saber mais sobre a vida dos animais e ter conhecimento sobre eles". (A13)

“É importante para aprender sobre os animais". (A11)

Com tais expressões, infere-se que discentes notam o Jardim Zoológico como um instrumento voltado para a aprendizagem, não somente como um espaço propício para o lazer e a diversão. Assim, percebe-se a presença de atitudes em respeito à ciência, pois os mesmos demonstraram interesse em estudar/aprender sobre os animais, em especificamente as serpentes. Conforme Pozo e Crespo (2009), quando o aluno desenvolve/demonstra atitudes em respeito à ciência o mesmo manifesta empenho e motivação por esta, e adota uma postura reflexiva em detrimento ao enfoque memorístico e estanque.

Ao serem indagados a respeito da importância das serpentes e o seu respectivo papel no meio ambiente, dois aprendizes explicitaram que:

1- As transcrições foram redigidas no presente trabalho conforme os aprendizes registraram no diário de campo e de acordo com as falas das gravações. 
"A importância das serpentes é limpar o meio ambiente e servir de alimento isso chama de cadeia alimentar ou teia alimentar e também se não tiver a cobra pode formar um desequilíbrio na cadeia alimentar”. (A7)

"É quando a serpente come o ovo ela joga a casca do ovo para fora e isso servem de nutrição pras plantas. E também serve de nutrição para outros animais”. (A1)

A ideia expressada por ambos denota o desenvolvimento/demonstração de um procedimento em relação à compreensão e organização conceitual da informação, uma vez que os mesmos correlacionaram conceitos mais complexos vistos anteriormente, na sala de aula, em relação à temática de ecologia e, ainda reconheceram a importância das serpentes para o equilíbrio ecológico. O estabelecimento de relações conceituais caracteriza-se pela integração de diversos conceitos para explicar um único fenômeno, e isso foi notado nas respectivas falas dos discentes (POZO; POSTIGO, 1994).

O desenvolvimento/demonstração de atitudes em relação à aprendizagem da ciência nos alunos foi percebido no registro de observação do pibidiano P4, quando o próprio explicitou aspectos voltados para a cooperação, interação, conduta e comprometimento durante a inserção do jogo didático proposto:

"Quando eles receberam as perguntas e tinham que responder e discutir em grupo, todos os alunos ficaram em silêncio e em seguida comentaram as respostas com os integrantes do grupo, na segunda rodada de perguntas aconteceu a mesma coisa, todos estavam envolvidos na atividade”. (P4)

O sucesso desse momento pode ser atribuído à inserção do jogo didático, considerando que o recurso construído, composto por problemas abertos, fomentou etapas de discussão, reflexão, interação e comunicação de ideias. Desse modo, Kishimoto (1997, p. 37) corrobora com esses dados e, acrescenta que a utilização desse material didático no domínio do ensinoaprendizagem promove [...] "a construção do conhecimento, introduzindo as propriedades do lúdico, do prazer, da capacidade de iniciação e ação ativa e motivadora”.

Após a atividade do jogo, foi distribuído para a turma um texto que abordava um pouco da história do Jardim Zoológico de Brasília-DF. Esse material elucidava os objetivos do Zoo, trazia uma discussão sobre os locais de onde os animais são retirados e discorria sobre a importância da manutenção dos mesmos em cativeiros e ainda, apresentava duas 
questões investigativas: "É possível soltar animais na natureza que nasceram em cativeiro, como no Zoo? Existe algum impacto ambiental ao soltarmos animais exóticos na natureza?”.

Depois de ser entregue o texto, foi sugerido que os discentes realizassem uma leitura silenciosa e registrassem no caderno dúvidas e curiosidades a respeito das informações contidas no mesmo. Durante o desenrolar da atividade, surgiram várias dúvidas e os aprendizes foram anotando e sublinhando no diário de campo. Dessa forma, enaltece-se a importância da estratégia adotada, posto que os textos podem ser ferramentas preciosas, já que exercem um papel muito importante no processo de ensino aprendizagem, desde que não lhe atribuíam apenas ações como ler e memorizar (ZABALA, 1998).

Para sanar os questionamentos manifestados, os mesmos foram para o laboratório de informática da escola no intuito de realizar uma busca na internet para sanar as possíveis dúvidas que surgiram com as questões propotas. Esse espaço contava com poucos computadores e com uma internet de baixa qualidade, no entanto os aprendizes conseguiram efetuar com eficiência a atividade proposta.

Assim sendo, cabe ressaltar que com a inserção dessa ação foi percebido o desenvolvimento/demonstração de alguns tipos de conteúdos procedimentais. No primeiro caso, o aluno A1 grifou no texto algumas palavras que não compreendiam o significado e buscou auxílio na internet para obter respostas, mostrando uma atitude de enfoque profundo. Com essa ação, percebe-se que foram realizados procedimentos de seleção, busca e captação da informação. As seguintes transcrições e a imagem retratam os procedimentos mencionados anteriormente (Figura 2):

"Permutas - trocar ou negociar com outras coisas que você não tem. Extinção quando uma espécie está sendo ameaçada ou retirada do seu local de vida”. (A1)

\section{Qual objetivo de manter animais em cativeiro?}

A manutenção de animais em cativeiro pode ser importante, pois auxilia no conhecimento e aproxima as características desses animais ao cidadão que, por vezes, nunca teria contato com ele. Fonte também de pesquisa científica e ações que possibilitam a reprodução de espécies ameaçadas de extinção, levando conscientização nara a população da importância dessas espécies para o meio ambiente. Muitos animais 
Outro procedimento de aquisição da informação voltados para a seleção, busca e captação da informação, juntamente com uma atitude de motivação, ficou evidente na expressão do pibidiano $\mathrm{P} 4$, onde o mesmo relatou que:

"Eles encontraram textos incríveis, imagens, fóruns, e conseguiram responder a maioria das perguntas". (P4)

"Os alunos conseguem fazer muitas associações que tem no cotidiano para o conteúdo, o que às vezes facilita o aprendizado dos outros alunos. Um aluno comentou sobre o filme Rio, que fala sobre a extinção das araras". (P4)

Em relação às questões investigativas propostas, obtiveram-se novamente conteúdos do âmbito procedimental, pois o aluno A3 foi ao encontro da aquisição da informação, uma vez que o mesmo pesquisou e buscou na internet subsídios para sanar as dúvidas levantadas. Observa-se também nas falas, o desenvolvimento/demonstração de atitudes referentes à ciência, considerando que foi adotada uma postura crítica e reflexiva, mostrando respeito pelo meio ambiente e ainda pode-se considerar o desenvolvimento/demonstração de uma atitude crítica em relação às aplicações da ciência na sociedade, onde o mesmo suscitou questionamentos acerca de alguns prós e contras referentes à manutenção de animais em cativeiros, como o Zoo. Assim, o estudante A3 relatou que:

"Lamentável que se use animais para a diversão do ser humano, não concordam?". (A3)

"Antes no Zoológico onde estão com os animais da mesma espécie e recebem comidas e tratamento médico do que estarem soltos para serem assassinados”. (A3)

De modo geral, é essencial que o professor insira em sua prática didático-pedagógica atividades que visem o tratamento continuado das atitudes, no intuito de desenvolver nos alunos o hábito de refletir, questionar e pensar, ao invés de focar na realização de exercícios rotineiros e repetitivos que pouco contribuem para uma aprendizagem mais efetiva e eficiente (POZO; CRESPO, 2009).

Ainda no rol das questões investigativas, também houve o desenvolvimento/demonstração de procedimento de interpretação da informação, tal elemento pode ser evidenciado na construção de desenhos, pelo aluno A3, no qual mostrava a diferença 
do olhar do animal na natureza e outro no cativeiro, apesar do discente também ter reconhecido a importância dos Zoos. Para a elaboração do desenho, ocorreu à aquisição da informação, considerando que o ato de observar e pesquisar foi crucial para a etapa de modelização (Figura 3).

De acordo com Zabala (1998), a observação é uma técnica que consiste em colocar os alunos em contato direto com as coisas, os seres, os fatos e os acontecimentos, promovendo a sistematização de outras atividades como: registro de dados, expressão oral e escrita. Essa ação obteve êxito para o aluno A3, considerando que o mesmo observou, refletiu, elaborou um modelo e ainda construiu uma expressão escrita.

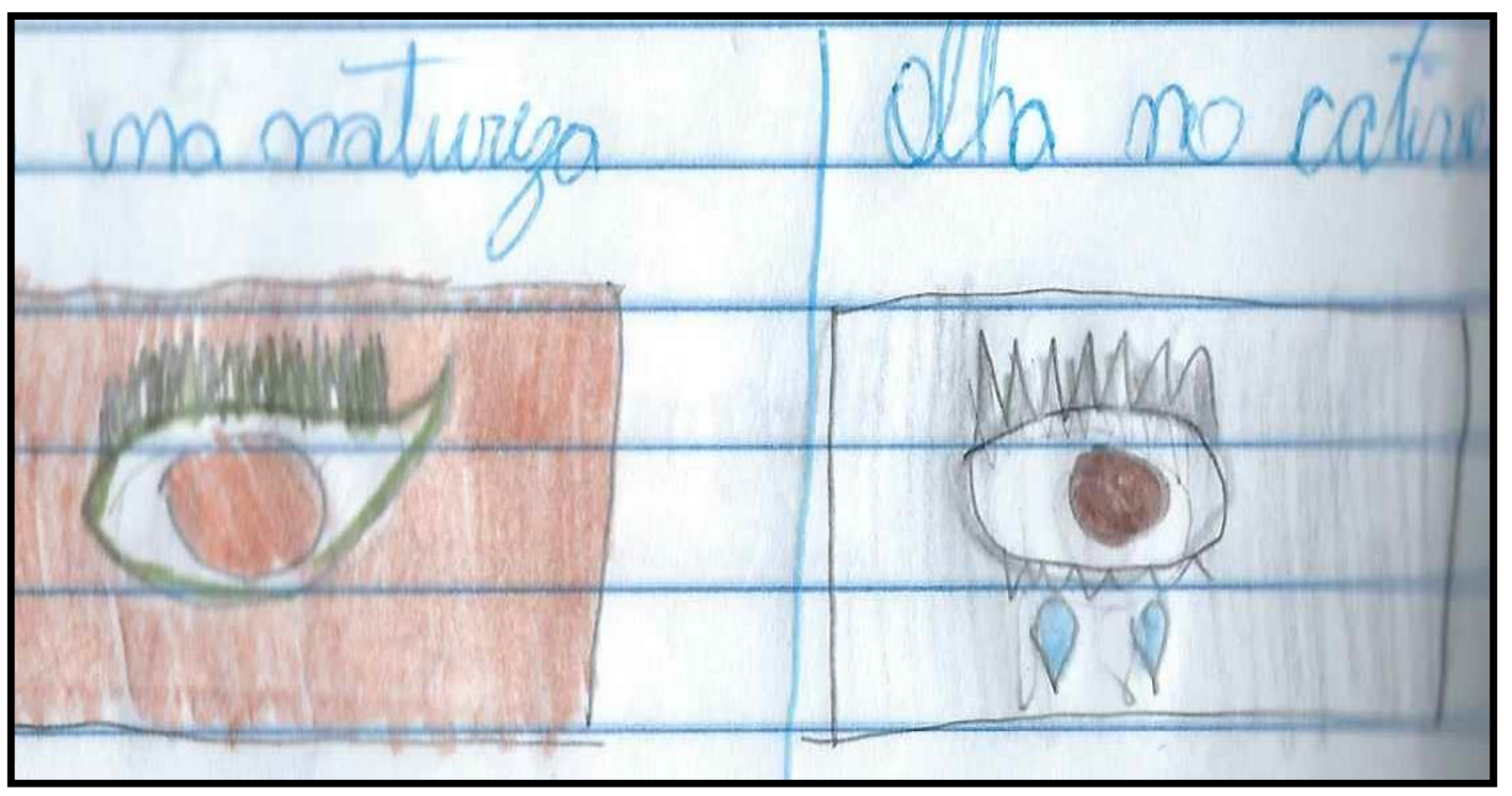

Figura 3 - Desenho realizado pelo aluno A3 mostrando a situação do olhar do animal em cativeiro e livre na natureza.

No panorama das atitudes também não foi diferente, vários elementos foram desenvolvidos/demonstrados. Tal fator ficou manifesto na imagem (Figura 4) e na escrita do pibidiano P1, que participou dessa etapa e explicitou que:

"Gostei muito das respostas dos grupos e percebi que eles conseguiram se organizar entre eles para pesquisar na internet”. (P1) 


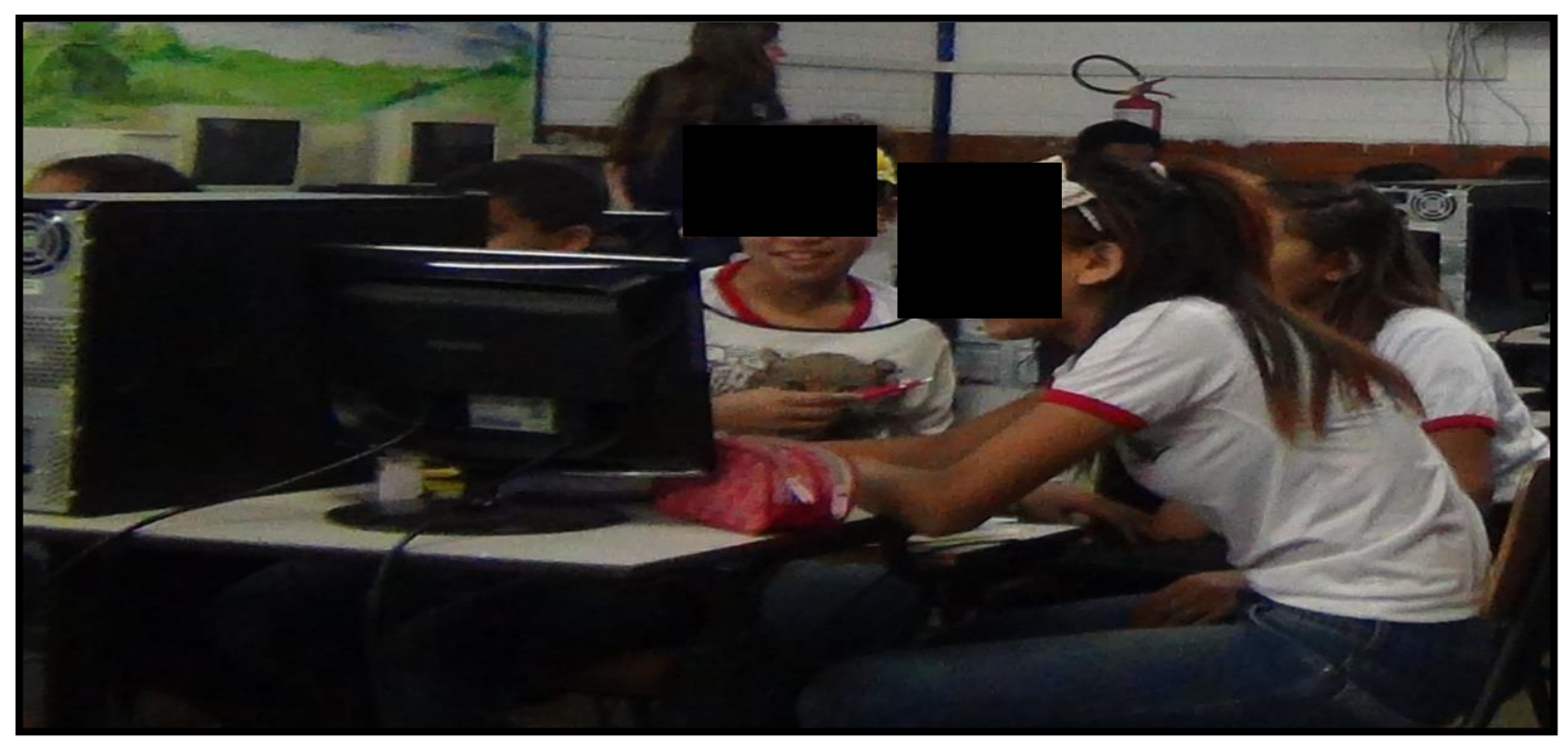

Figura 4 - Organização e interação de um grupo durante as atividades propostas.

Com essa ação, ficou nítida a ocorrência de atitudes em relação à aprendizagem da ciência, pois os discentes debateram e refletiram durante a pesquisa em grupo, demonstrando colaboração e solidariedade mediante a ação proposta. Nesse sentido, Zabala e Arnau (2010, p. 89) complementam que "cooperação com iniciativa e responsabilidade nas tarefas compartilhadas, participando de modo ativo e mostrando interesse, flexibilidade e respeito às ideias alheias" [...] são exemplos de conteúdos de corpus atitudinal. Outros episódios marcantes em relação a esse tipo de atitude apareceram quando alguns alunos pediram para ampliar a carga do minicurso e registraram no diário de campo que:

"As perguntas são muito interessantes por que falamos da vida do animal, como tratar um animal no zoo e na natureza”. (A10).

Assim, ressalta-se a importância das mediações realizadas pelos pibidianos durante o processo de aplicação das atividades planejadas no primeiro encontro, onde os mesmos auxiliaram, instigaram os alunos e possibilitaram que estes refletissem sobre as questões que estavam sendo tratadas. Desse modo, Zabala (1998, p. 63) destaca que o professor é o ser que é capaz de [...] "detectar um conflito inicial entre o que já conhece e o que se deve saber, que contribui para que o aluno se sinta capaz e com vontade de resolvê-lo, que propõe o novo conteúdo como um desafio interessante, cuja resolução tenha alguma utilidade" [...] 
intervindo de forma ponderada nas suas atuações, maximizando as possibilidades do desenvolvimento da autonomia e da reflexão crítica.

Para finalizar, ressalta-se que a proposta didática abriu espaço para o desenvolvimento /demonstração de alguns tipos de conteúdos procedimentais e atitudinais nesse encontro, considerando que a intencionalidade didática era incluir estes elementos como objetivos a serem alcançados pelos discentes. Ao longo do trabalho, vem sendo utilizado o termo "desenvolvimento/demonstração" quando aparece alguma atitude ou procedimento, considerando que não se sabe se esses elementos foram formados, se já existiam ou se apenas se manifestaram. No entanto, pode-se destacar que as tarefas, as estratégias adotadas e o processo mediacional, foram artifícios que contribuíram para o surgimento de tais conteúdos, diferentemente de atividades voltadas para a memorização.

\subsection{2 - $2^{\circ}$ Encontro (20/08/15) - Conhecendo a Situação Atual e a Localização do Jardim Zoológico de Brasília-DF}

Os pibidianos P1, P4 e o P5 foram os responsáveis por apoiar este encontro juntamente com a professora, estes participaram da etapa de regência, registro de dados e observação dos aprendizes.

A primeira atividade aplicada nesse encontro foi referente à busca de notícias recentes sobre o Zoológico de Brasília-DF. Com a proposta, os educandos tinham como lição para casa, pesquisar algumas entrevistas, noticiários, enquetes e vídeos que abarcassem histórias sobre o espaço não formal, em estudo, e trazer para a sala de aula no intuito de compartilhar o material coletado com os colegas.

Dessa forma, o pibidiano P5 perguntou para a classe se todos tinham realizado a pesquisa, no entanto apenas alguns alunos da turma haviam concluído a tarefa solicitada, declarando que estavam sem internet e a escola, infelizmente, não oferecia esse instrumento de pesquisa para eles (Figura 5). Assim, a classe foi configurada em quatro grupos para possibilitar a discussão e a troca de ideias iniciais sobre o material pesquisado. 


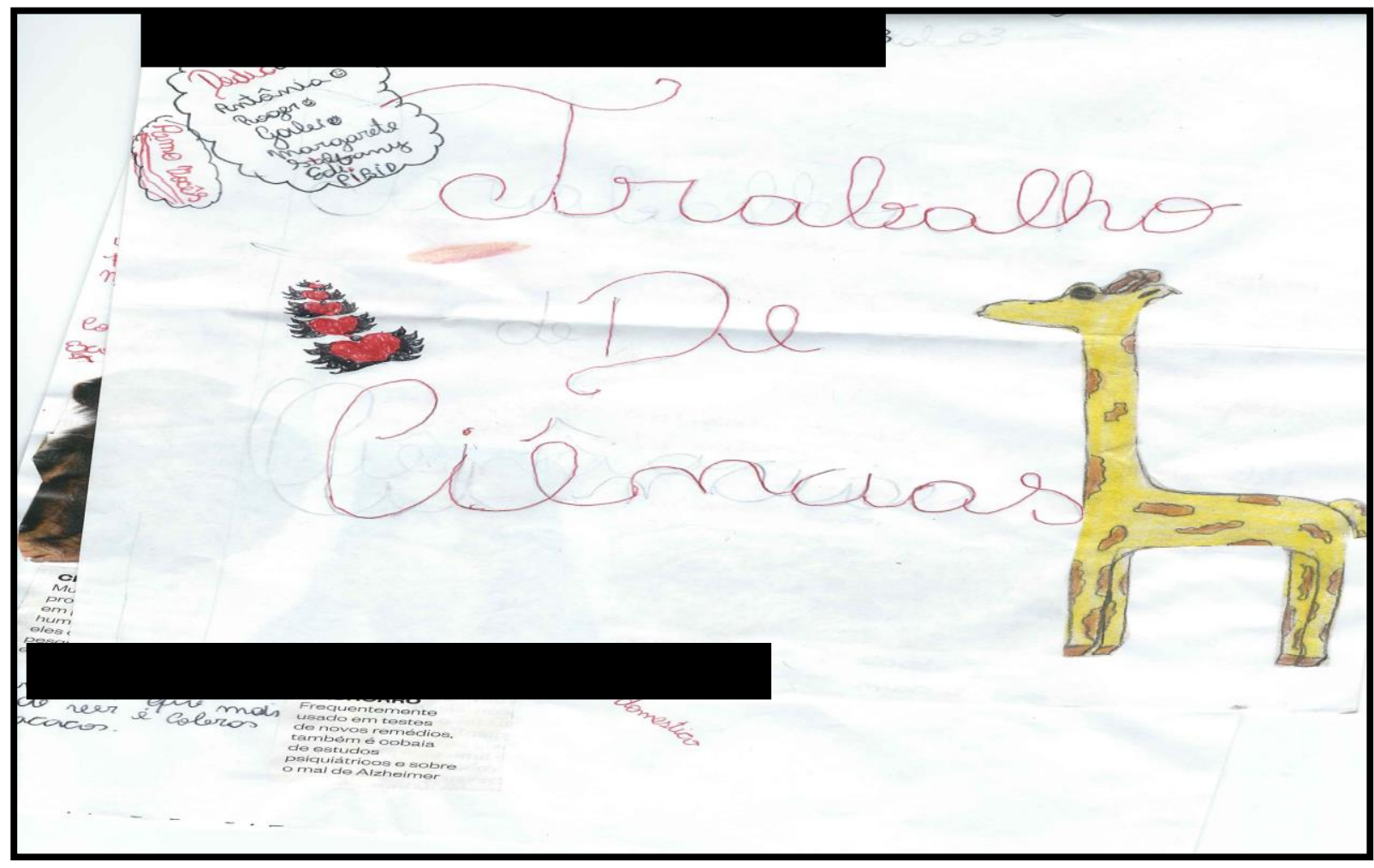

Figura 5- Pesquisa realizada pelo aprendiz A17.

O primeiro grupo selecionado para expor a pesquisa, elucidou informações referentes à importância do Zoológico, apontando que esse espaço pode ser utilizado para o lazer, a pesquisa e a preservação de espécies biológicas.

Vários procedimentos e atitudes foram desenvolvidos/demonstrados com a referida tarefa. A princípio houve a apropriação de um procedimento de aquisição da informação, pois o aprendiz A10 efetuou um processo de busca e captação da informação ao executar a pesquisa sobre uma notícia recente acerca do Zoo. Esse procedimento é alcançado quando o educando é capaz de ir ao encontro de diversos meios de pesquisa, como bibliotecas, documentos, internet, rádio e outros, para importar informações pertinentes ao problema em questão (POZO; POSTIGO, 1994).

Considerando que em um trabalho inicial é bem provável que o educando ainda não possua o domínio das estratégias necessárias para a resolução de problemas, é essencial que esse receba um apoio externo para a consecução da meta proposta e provável desenvolvimento/demonstração de procedimentos (POZO; POSTIGO, 1994). Nesse caso, ressalta-se que o pibidiano orientou que os alunos realizassem pesquisas no intuito de fazer um levantamento da situação atual do Zoo de Brasília, mas a ação de ir investigar as informações foi completamente deles, o docente agiu apenas como mediador. 
Ainda sobre o primeiro grupo, apenas o aluno A10 fez a pesquisa, no entanto o mesmo compartilhou as informações recolhidas com os demais colegas. Esse fato é voltado para o desenvolvimento/demonstração de uma atitude em relação à aprendizagem da ciência, levando em consideração que houve indícios de trabalho em equipe entre os educandos. Essa atitude mostra que o discente adotou uma postura cooperativa em oposição à competitiva e traços de solidariedade em aversão ao individualismo (POZO; CRESPO, 2009).

Após a realização da leitura das notícias disponibilizadas pelo aprendiz A10, cada discente registrou no seu diário de campo um subtema a ser explorado na comunicação da informação, isso mostrou o desenvolvimento/demonstração de um procedimento tornado para a compreensão e organização conceitual da informação, tendo em vista que eles sistematizaram quais tópicos elucidariam na apresentação. Tal fator pode ser verificado nas seguintes transcrições:

"Vou falar porque é importante o zoológico: o zoológico serve para os animais se alimentarem muito bem e para nós conhecermos os animais”. (A5)

"O zoológico possui vários objetivos, dentre os quais o lazer, a pesquisa, a preservação e a educação ambiental”. (A9)

"Muitas pessoas criticam o zoológico por que acham que é errado manter animais em cativeiro”. (A16)

"Profissionais, como veterinários e nutricionistas, cuidam da saúde e da alimentação dos animais". (A21)

O procedimento de organização de conceitual é estabelecido quando o aprendiz consegue estruturar o conhecimento utilizando redes semânticas, mapas conceituais, registros e outros, tal elemento auxilia na sistematização de ideias na mente do mesmo (POZO; POSTIGO, 1994).

Outro procedimento utilizado pelo grupo foi referente à comunicação da informação na forma escrita, ao registrar dados no caderno de campo, e na tipologia oral, ao expressar o resultado das pesquisas para toda a turma (Figura 6). 


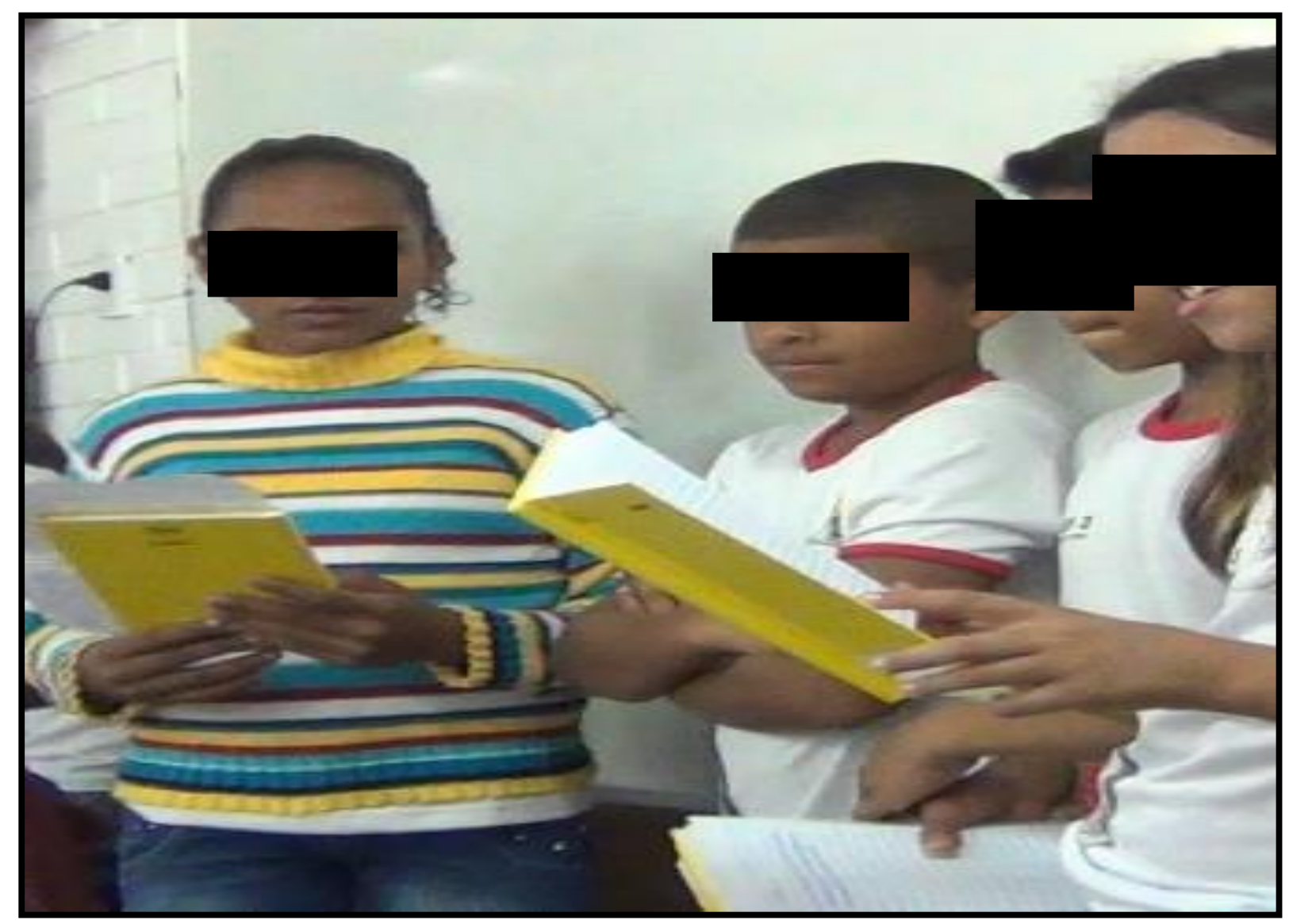

Figura 6 - Discentes comunicando as informações obtidas por meio da pesquisa realizada.

Conforme a expressão do pibidiano P5 em relação ao grupo 1, pode-se observar também o aparecimento de atitudes em relação a ciência, considerando que o licenciando discorreu que os aprendizes manifestaram atitude crítica e reflexiva perante a manutenção de animais em cativeiro:

“O primeiro grupo que apresentou trouxe pontos bem interessantes sobre o zoológico. O que mais me chamou a atenção foi em relação a crítica, que muitas pessoas fazem, dizendo que o zoológico é um cativeiro para os animais e não um bom lugar para os eles”. (P5)

Promover espaços de participação autônoma é uma estratégia adequada para combater a passividade que tanto é motivo de reclamações e queixas pelos professores. Questiona-se ainda que os educandos não têm sensibilidade perante aos problemas sociais, científicos e tecnológicos que os rodeiam, mas alguns docentes ensinam a ciência como algo isolado da realidade, apresentando-a como um conjunto de conhecimentos. Para que essa realidade seja transformada, é de extrema relevância que o educador valorize as ideias dos aprendizes, 
estimulando que os mesmos reflitam sobre essas e adotem uma postura crítica acerca dos fatos científicos, conforme os pibidianos fizeram nesse momento (POZO; CRESPO, 2009).

O segundo grupo trouxe informações referentes às características gerais dos animais, área e localização do Zoo e sobre o processo de tratamento destes por meio de técnicas de acupuntura e laserterapia. Com a intervenção dos alunos, pode-se perceber o desenvolvimento/demonstração de atitudes em relação à aprendizagem da ciência quando o aprendiz A7 auxiliou o A20 a recordar os conhecimentos que este explicitaria para a turma.

Oportunizar que os aprendizes desenvolvam/demonstrem esse tipo de atitude é extremamente importante, considerando que "o trabalho cooperativo introduz os alunos nos aspectos sociais da ciência, além de proporcionar oportunidades para o desenvolvimento de habilidades básicas de aprendizagem" (RODEN; WARD, 2010, p. 25).

Um marco interessante nessa apresentação foi quando o aprendiz A17 traduziu a informação obtida para os componentes do seu grupo. Dessa forma, alguns educandos anotaram os elementos que julgaram mais interessantes no diário de campo, e dessa forma ficou evidente, mais uma vez, o surgimento de procedimentos de aquisição e interpretação da informação.

O terceiro grupo evidenciou as características do Zoológico de Brasília-DF, discorreu sobre a dificuldade de manter animais doentes em virtude do custo e ainda a questão da extinção. Um fator marcante originou-se quando discente A1 questionou o A17 acerca do tamanho da área do Zoo, já que o mesmo explicitou dados referentes ao Zoo. Assim, mostrase o desenvolvimento/demonstração de procedimentos de análise da informação e realização de inferências, visto que o aluno desenvolveu uma das etapas do método de investigar que são expostos por Pozo e Postigo (1994), que nesse caso foi o modo de fazer perguntas.

No último grupo, ocorreu um caso notório, pois nenhum dos integrantes realizou a pesquisa sugerida, no entanto os mesmos selecionaram as informações dos outros grupos e apresentaram uma reflexão acerca da importância de preservar os animais, tendo em vista que algumas espécies estão em estado de extinção. Isso demonstra a aquisição de procedimentos de seleção da informação e de organização conceitual. Nesse sentido, os aprendizes afirmaram que:

"Então gente, eles falaram muito sobre maus tratos, eu prestei atenção que muitos e muitos e todos principalmente falaram sobre isso e eu também, então gente é porque tem muitos animais que ficando em extinção e não pode porque a gente vai ficar sem ver os bichinhos". (A14) 
"A gente também não pode sujar o habitat natural deles, porque tipo sobre esse negócio de fogo, se a gente tacar fogo na floresta assim todos esses pássaros que a gente acha bonitinho vão sumir tudinho”. (A15)

Tais expressões, também evidenciam o desenvolvimento/demonstração de atitude em relação à ciência, visto que os aprendizes demonstraram ter preocupação e respeito pelo meio ambiente, explicitando como a interferência humana por atuar neste. É interessante salientar, a contribuição da estratégia inserida para a edificação desse tipo de atitude, já que esta ancorou uma ampla reflexão por parte dos alunos. Assim, ressalta-se que a prática de exposições em público, como as que foram inseridas ao longo do minicurso, são necessárias para permitir que os discentes sintam-se mais envolvidos na situação proposta, desenvolvendo um maior interesse e apreço pelo tema que antes não possuía. Logo, considera-se que tal assunto será mais persuasivo para o aluno e fará com que este "[...] reflita e faça uma avaliação mais profunda não só do tema da exposição, mas também das atitudes que possui em relação a ele e ao modo como influi na sua vida" (COLL et al., 1998, p. 169).

A outra atividade explicitada nesse encontro foi referente ao ZooMapsBrasília. Esse aplicativo conta com uma galeria de imagens com descrições e localização dos animais no Zoo, horários de funcionamento e ainda apresenta um mapa para auxiliar na locomoção com os diferentes meios de transporte. Desse modo, no momento inicial, o pibidiano P4 solicitou que os aprendizes que possuíssem celular com sistema android abrissem a Play Store e fizessem o download do aplicativo. Após isso, em grupo, os estudantes foram orientados a manipularem o instrumento e a registrarem dados contidos neste que considerassem relevantes.

Com a intervenção, notou-se, inicialmente, o desenvolvimento/demonstração de conteúdos atitudinais em relação à aprendizagem da ciência, pois cada grupo, devido às dificuldades, ficou apenas com um celular e com uma internet de baixa velocidade, e, contudo, os educandos conseguiram organizar o tempo, compartilhar o material entre eles e auxiliar os colegas no momento da coleta de informações. Apesar de tal ação não ter acontecido de forma proposital, percebeu-se que os aprendizes conseguiram lidar com o empecilho de forma cooperativa. Assim, Carvalho et al., (2009), destaca que quando os alunos estão inseridos em atividades que os façam pensar e raciocinar, por meio da interação entre eles, os mesmos conseguem romper com o egocentrismo e criam, com naturalidade, um clima de cooperação. 
Mesmo com a disponibilidade do aplicativo para a realização da atividade, o estudante A7 trouxe para o encontro uma nova fonte de pesquisa. Tal material apresentava tópicos que retratavam algumas curiosidades e características acerca de determinadas espécies de serpentes. O uso do recurso refletiu de forma extremamente positiva em relação ao desenvolvimento/demonstração de ambos os tipos de conteúdos em análise, uma vez que houve o aparecimento da aquisição da informação, tendo em vista que o discente foi capaz de transcender o habitual e foi em busca de outros meios de pesquisa (Figura 7).

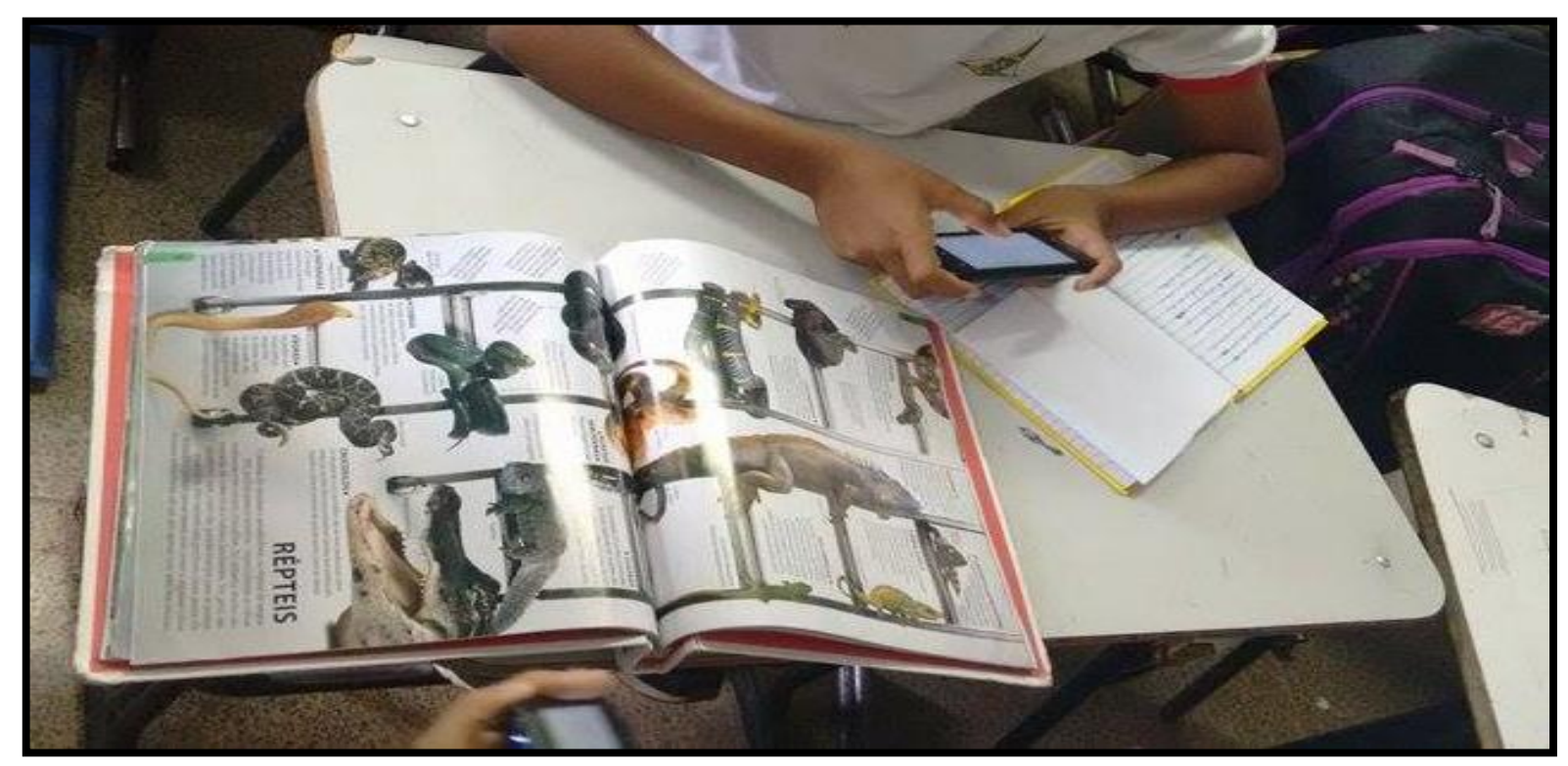

Figura 7 - Material apresentado pelo aluno A7 sobre serpentes.

Além do mais, foram desenvolvidas/demonstradas atitudes em relação à ciência, visto que vários aprendizes sentiram-se motivados para realizar a leitura e discutir sobre as informações científicas contidas no livro. Dessa forma, ressalta-se que a motivação é um estímulo que leva os discentes a investirem um maior esforço para a realização de metas, possibilitando ainda uma maior participação e envolvimento nas atividades, favorecendo a edificação de conhecimentos e habilidades (BORUCHOVITCH; BZUNECK, 2009).

Após a manipulação do aplicativo, os educandos noticiaram para a turma as informações que notaram relevantes acerca do instrumento. O primeiro grupo relatou dados referentes às características de alguns animais. Um ocorrido curioso apontado por dois aprendizes desse grupo foi pertinente às informações obtidas por meio do livro do aluno A17, os mesmos mencionaram conhecimentos sobre animais que não existem no Zoo de BrasíliaDF: 
"A orca, baleia e golfinho nadam movimentando a cauda musculosa para cima e para baixo, eles vem a superficie para respirar”. (A18)

"Os morcegos são mamíferos que podem voar”. (A9)

“As toupeiras são adaptadas para viverem em tuneis subterrâneos”. (A9)

Com esse relato, ficou explícito que os aprendizes foram além do esperado e desenvolveram/demonstraram procedimentos de busca e captação da informação, instituindo uma atitude voltada para a autonomia. A capacidade autônoma emergida é um reflexo da forma como as atividades foram planejadas e mediadas ao longo do minicurso, colocando sempre o educando como o protagonista na construção do seu próprio conhecimento, rompendo com a verticalização do processo de ensino aprendizagem e, considerando que é importante “[...] criar alunos autônomos, que saibam pensar, tomar as próprias decisões e estudar sozinhos [...]" (CARVALHO et al., 2009, p. 27).

Para complementar as informações expostas pelo grupo, o pibidiano P4 enunciou a seguinte questão:

"E o que tem mais no aplicativo?". (P4)

Logo, o educando A10 afirmou que:

"Sobre as fotos, as fotos dos animais, e como você pode ir para lá, a entrada, pessoas de com menos de 5 e mais que 60 anos não pagam e também você tira uma foto na câmera e aparece a foto de um animal" (A10)

Essa expressão enfatiza a progressão de um procedimento vinculado para a compreensão e organização conceitual e comunicação da informação, visto que o estudante foi capaz de sintetizar os apontamentos descritos no aplicativo na forma escrita e expor oralmente os dados para toda a turma. A manifestação desse último tipo de procedimento em suas diversas modalidades tem sido constante, pois alguns aprendizes automatizaram, de maneira rápida e eficiente, esse procedimento. Conforme Pozo e Crespo (2009), o papel do professor nessa etapa é bem diferente do tradicional e rotineiro explicar. Trata-se de fornecer apoio e atuar estabelecendo a prática, permitindo que o educando enfrente cada vez mais tarefas com caráter aberto, para que possa dominar e assumir um controle estratégico sobre a aprendizagem dos procedimentos, que nesse caso foi o processo de comunicação da informação. 
Os alunos do segundo, terceiro e quarto grupo, elucidaram a opinião deles em relação ao aplicativo:

“Ele faz a gente aprender mais sobre os animais que a gente não conhece”. (A16)

“Descobri sobre os habitats dos animais”. (A9)

"No ZooMapsBrasília você consegue ver os animais que são de fora do Brasil”. (A4)

“É importante porque você consegue se localizar". (A5)

"Nós gostamos muito desse aplicativo e queremos aprender mais sobre ele". (A17)

Ao analisar esses argumentos, nota-se que o aplicativo pode ser um meio para auxiliar o desenvolvimento/demonstração de atitudes em relação à ciência, pois os discentes citados anteriormente reconheceram o instrumento como um objeto que despertou o interesse pela ciência, demonstrando motivação e entusiasmo pelo seu estudo. Evidencia-se nas falas, que o aplicativo também proporcionou a seleção de informações que os mesmos julgaram relevantes.

O discente A4 ainda pediu para relatar para a turma dados acerca dos animais em extinção no Brasil:

“Onça pintada, cervo do pantanal, arara azul, peixe boi, surucucu, macaco-aranha, pirarucu, flamingo, arara azul, tatu canastra”. (A4)

Curiosamente, o pibidiano P4 perguntou:

“Quando você pesquisou? Agora? Por quêe?”. (P4)

$\mathrm{O}$ aprendiz A4 respondeu:

"Despertou a minha curiosidade". (A4)

A ação do aprendiz A4 mostra que ele foi além das expectativas esperadas, já que este foi capaz de formular um questionamento por si só, ir atrás de uma possível solução para este e ainda comunicou tal conhecimento para a turma. Logo, vislumbra-se a importância entre a interação aluno-professor, dado que o estudante viu no encontro um espaço favorecedor do diálogo e da reflexão, permeando que o mesmo passasse da “[...] ação manipulativa à intelectual, estruturando seu pensamento e apresentando argumentações discutidas com seus colegas e professores" (CARVALHO, 2013, p. 10). 
Para finalizar o encontro, foi sugerida a realização da atividade "Localização: Ida ao Zoo de Brasília - DF”. A questão que norteava essa etapa era a seguinte: “Onde estou? Para onde vou?". Assim, os alunos tentaram utilizar o mapa presente no ZooMapsBrasília para delinear a trajetória de ida ao Zoo, no entanto devido à baixa velocidade da internet não foi possível a consulta. Com isso, a professora providenciou um mapa e entregou para cada grupo. Enquanto a docente preparava o material, os grupos ficaram discutindo acerca dos meios de locomoção para a ida ao espaço não formal, no intuito de resolver a indagação exposta. Como o tempo destinado para a realização do encontro estava acabando, solicitou-se que os mesmos, em grupo, realizassem a atividade em casa.

Ao avaliar esse encontro no seu âmbito geral, verifica-se que tal intervenção repercutiu valiosas contribuições para os alunos, já que ocorreram momentos de pesquisa, reflexão e comunicação da informação. Alguns pibidianos afirmaram que:

"Os discentes trouxeram informações além daquelas que estavam nas reportagens, acabaram recordando de outras informações que eles tinham tomado conhecimento através da mídia”. (P4)

"A maioria dos grupos, no momento da discussão, conseguiram conversar e discutir sobre a pesquisa, desenvolvendo um bom trabalho em equipe”. (P5)

Esse êxito apresentado pode ser atribuído ao molde como as atividades foram inseridas no contexto escolar pelos pibidianos, uma vez que não eram oferecidas respostas prontas para os questionamentos dos alunos, mas estes eram instigados a buscá-las, confrontando ideias, selecionando informações e discutindo resultados, em um trabalho grupal. Complementarmente, Zabala (1998) expõe que o docente, na sua função de mediador, deve orientar os estudantes a explorarem suas ideias prévias, proporcionando experiências no intuito de fazer estes refletirem, pensarem, analisarem situações, de modo autônomo ou coletivo, guiando estes para a aprendizagem dos diversos tipos de conteúdos.

Com a intervenção, percebeu-se que os discentes começaram a progredir, principalmente no que diz respeito à aquisição de alguns procedimentos e aos poucos foram adquirindo estratégias. Tais elementos também apareceram interpostos e articulados não seguindo restritamente a ordem que aparece na Tabela 1 proposta por Pozo e Crespo (2009).

Além do mais, cabe enfatizar que os procedimentos mais desenvolvidos/demonstrados até esse encontro, foram os referentes à comunicação da informação. Pozo e Postigo (1994) explicitam a importância desses elementos para o processo de ensino aprendizagem, 
considerando que qualquer avaliação do educando, tanto no âmbito procedimental, como no atitudinal e conceitual, é mediada por meios expressivos escritos e de comunicação oral. Por meio da análise, verificou-se também que esses estão estreitamente vinculados entre si, tanto na forma verbal como na escrita. Tal fator foi visualizado no decorrer dos encontros, pois os alunos registraram diversas informações relevantes no diário de campo e também expressaram estas de forma significativa nos intercâmbios de comunicação oral.

As atitudes, apesar de serem os conteúdos mais difíceis de serem observados, avaliados e até mesmo de permanecerem estáveis, em relação aos procedimentos e conceitos, elas progrediram ao longo do minicurso, principalmente no que diz respeito à motivação e a colaboração (POZO; CRESPO, 2009).

Apesar dos conceitos não serem o motivo de análise nessa pesquisa, não se reduz a importância desses para o processo de ensino aprendizagem, considerando a relevância da tríade conceitos-procedimentos-atitudes para a formação integral e global do educando (COLL et al., 1998). Assim, é importante considerar o aluno tanto pelas respostas que exploram seu raciocínio lógico, pela forma como explicita essa ideia, pelo entendimento de certo conceito, quanto pela opinião crítica, pelo modo que interage com o educador e colegas, pelos valores pessoais (LIMA, 2000).

\subsection{3 - $3^{\circ}$ Encontro (27/08/15) - Preparação de Ida ao Zoo-DF - Construção de Bilhetes e Mapas e Discussão Inicial sobre A Importância das Serpentes}

Os pibidianos P4 e P6 ministraram esse encontro, enquanto o pibidiano P3 e a professora supervisora registravam em ata as observações e as ações dos aprendizes durante as atividades propostas.

No momento inicial, os educandos apresentaram para os colegas os mapas construídos para resolver a questão problema exposta no encontro anterior: "Onde estou? Para onde vou?" A elaboração de mapas foi um exercício que possibilitou aos envolvidos realizar a leitura e a produção da linguagem cartográfica, desenvolvendo uma série de procedimentos das mais diversas categorias expostas por Pozo e Crespo (2009):

a) Aquisição da informação - ao receber um protótipo do mapa de ida ao Zoo-DF, os alunos observaram este material, selecionaram informações presentes neste para a 
construção do novo recurso. Além do mais, os mesmos agregaram novos elementos ao mapa confeccionado, como a distância, o tempo aproximado gasto para ir ao Zoo-DF, as trajetórias, os meios de locomoção. Para adicionar tais dados, infere-se que os discentes realizaram procedimentos de busca e captação da informação (Figura 8).

b) Interpretação da informação - os aprendizes interpretaram as informações presentes no protótipo para transpor para o mapa construído, utilizando o inicial como modelo.

c) Análise da informação e realização de inferências - o aluno A1 desenvolveu formas de fazer perguntas, pois o grupo desenhou na cartolina o Ceasa-DF e quando o pibidiano P4 questionou a figura, A1 anotou a questão no diário de campo e afirmou que iria pesquisar. Ao analisar o caderno do A1, verificou-se que a pesquisa foi realizada: "O que é o CEASA? É um lugar aonde vende frutas, tipo uma feira bem grande". (A1)

d) Compreensão, organização conceitual e comunicação da informação - pela organização dos dados dispostos nos mapas, visualizou-se que os educandos conseguiram realizar a leitura cartográfica e dispor de dados importantes para auxiliar na localização espacial, uma vez que os mesmos acrescentaram pontos de referência no mapa. Em relação à comunicação da informação, verificou-se que os alunos conseguiram comunicar seus conhecimentos, dominando tanto os recursos orais tanto os de representação escrita.

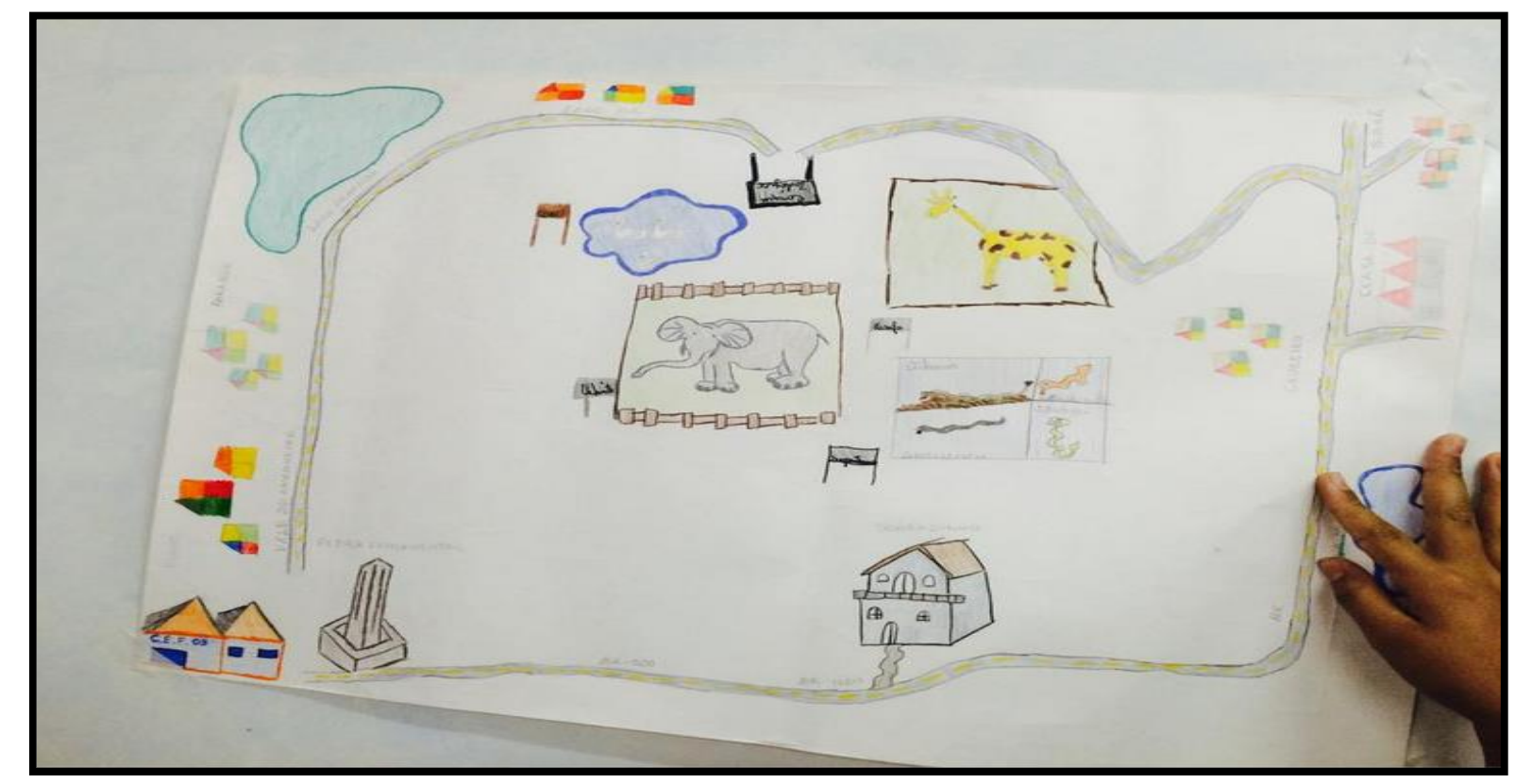

Figura 8- Mapa de ida ao Zoo-DF construídos pelos educandos de um determinado grupo. 
Com isso, verifica-se que com um simples recurso e adotando uma vertente voltada para a resolução de um problema, foi possível gerar vários procedimentos nos educandos, incentivando estes a concluírem um problema, que nesse caso foi à trajetória de ida ao ZooDF. Inserir a turma em situações que gerem conflitos, curiosidades e questionamentos, é essencial para que estes assumam uma postura científica, haja vista que os aprendizes não podem [...] "se tornar cientistas investigativos por um processo semelhante á osmose, adquirindo habilidades, posturas e conceitos apenas "por estarem lá" (WARD et al., 2010, p. $85)$.

Em seus relatos, o pibidiano P4 também descreveu o desenvolvimento/demonstração de procedimentos por parte dos alunos:

“Alguns grupos levaram esse material para casa e com a ajuda dos responsáveis acrescentaram informações que eles julgavam ser importantes. Os mapas ficaram maravilhosos e muito ricos em detalhes, eles foram muito além do mapa que foi entregue a eles para ser utilizado como guia, utilizaram o aplicativo ZooMapsBrasília como ferramenta de pesquisa e contaram com as informações que foram passadas pelos colegas que já tinham ido ao Zoo em outras oportunidades”. (P4)

Essa expressão evidencia um procedimento de aquisição da informação, tendo em vista que houve a busca e captação da informação, pois os estudantes entraram em contato com novas fontes de pesquisa. Além desse procedimento ser extremamente importante, devese considerar que é necessário que haja uma discussão acerca da seguridade das fontes de informações, para que os aprendizes compreendam que tais meios nem sempre apresentam dados confiáveis, logo se torna crucial que os mesmos aprendam a selecionar as informações obtidas e assumir uma postura mais crítica e reflexiva em relação a essas. Desse modo, Pozo (2007) alerta que o leitor deve portar a construção do próprio olhar e tomar uma leitura crítica de informações difusas e desorganizadas, adotando uma assimilação mais crítica. E ainda, corroborando com essa perspectiva, Pozo e Crespo (2009, p. 24) afirmam que "os alunos da educação científica precisam não tanto de mais informação (embora possam precisar também disso), mas sobretudo de capacidade para organizá-la e interpretá-la, para lhe dar sentido".

O aparecimento de atitudes também foi algo notável com a inserção da atividade em discussão. Houve o surgimento da motivação, mas a atitude que mais ficou explícita foi referente ao trabalho em equipe, pois os alunos afirmaram que alguns participantes realizaram a pesquisa, outros pintaram e o restante desenhou, demonstrando uma excelente postura 
cooperativa, priorizando a coletividade. Assim, evidencia-se que a cooperação "é uma virtude que precisa ser incentivada e, para isso, são necessárias intervenções do professor para desenvolver nos alunos o sentimento da importância dessa cooperação" (BARBOSA; JÓFILI, 2004, p. 60).

Os pibidianos P3 e P6 apontaram ainda como algo interessante à desenvoltura do aluno A14, afirmando que:

"Nas apresentações o discente A14 mostrou uma grande segurança na hora da apresentação auxiliando os colegas, mostrou ser muito dinâmico”. (P3)

"O aluno A14 apresentou com uma metodologia muito legal, ajudando até os próprios alunos do grupo". (P6)

A intervenção orientada para o auxílio, solidariedade e trabalho em equipe pode ser classificada como uma atitude em relação à aprendizagem da ciência. Nesse sentido, ressaltase que a aprendizagem não se deve restringir apenas a aquisição de conceitos ou procedimentos, mas torna-se essencial considerar aqueles que possibilitam a mobilização das capacidades mais afetivas, voltados para as relações interpessoais e de inserção social, estimando que estes possam mobilizar ações que edificam um olhar mais cooperativo, solidário, diminuindo o individualismo (ZABALA, 1998).

Além do mais, o aprendiz A14 ainda desenvolveu/demonstrou formas de fazer perguntas para que todos os integrantes do grupo pudessem participar do intercâmbio de informações. Desse modo, o aluno A14 adotou curiosamente, de forma autônoma e ativa o papel dos pibidianos, atuando como mediador, ao desenvolver questões para explorar os conhecimentos dos seus colegas no intuito de promover a reflexão, interação e participação dos discentes. Dessa forma, evidencia-se que as atitudes de pessoas significativas, como nesse caso, as pessoas responsáveis pelo processo mediático de ensino, intervêm como contraste e modelo, influenciando e persuadindo o modo de pensar e agir de outros indivíduos (ZABALA, 1998). Assim, reconhece-se que a atitude do aluno não é isolada, mas está estreitamente vinculada ao modelo de professor exposto (CARVALHO, 2009).

E ainda foi desenvolvida/demonstrada uma atitude crítica e reflexiva em respeito à ciência, quando o discente A14 sugeriu que os mapas construídos fossem utilizados no trajeto de ida ao Zoo-DF, para servirem como um instrumento orientador. Nesse caso, o aluno percebeu-se como um agente ativo até mesmo no planejamento do minicurso, já que este foi capaz de indicar uma estratégia para ser aplicada. 
Outra atividade inserida nesse encontro foi referente à construção de um bilhete visando à autorização e o agendamento do Zoo-DF para a realização da visita em um momento posterior. Dessa maneira, o pibidiano P5 solicitou que os estudantes elaborassem, em grupo, tais documentos.

Conforme Pozo e Postigo (2004), a comparação da informação, envolve o estabelecimento de relações entre vários modelos ou entre um modelo e determinados dados. Mediante as discussões, percebeu-se então o desenvolvimento/demonstração desse tipo de procedimento, tendo em vista que os aprendizes compararam os dados presentes em outros materiais para construir o próprio. Houve também a aquisição da informação, já que os mesmos selecionaram os elementos mais importantes, como data, horário, importância de ir ao Zoo, local e outros, para expor nos seus bilhetes. Isso pode ser retratado na própria fala:

"A gente recebe o bilhete que não vai ter aula, a gente pega um pouquinho dele e vai formando o nosso". (A1)

Após cada grupo elaborar os bilhetes solicitados, foi requerido que cada grupo apresentasse estes e registassem no quadro branco os dados importantes que não poderiam faltar em cada um dos documentos (Figura 9).

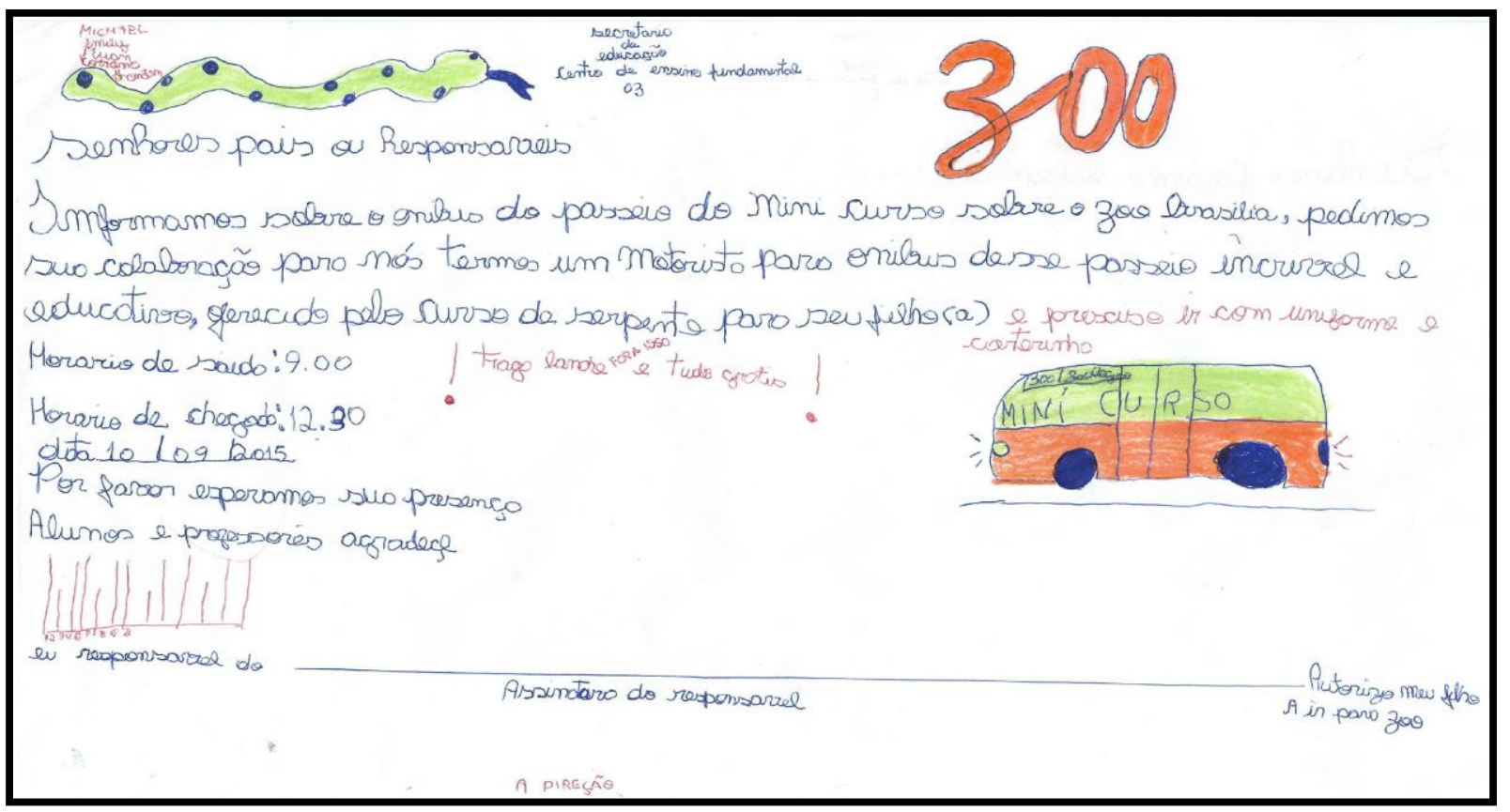

Figura 9- Bilhete confeccionado por determinado grupo. 
Assim, no decorrer da etapa de comunicação da informação dos materiais construídos, o pibidiano P5 perguntou ao primeiro grupo:

“Gente, como vocês chegaram a esse modelo?”. (P5)

O aprendiz A15 salientou que:

"Nós começamos a discutir como fazer, fomos trocando ideia”. (A15)

Novamente, ressalta-se o desenvolvimento/demonstração de atitudes em relação à aprendizagem da ciência, visto que os colegas colaboraram entre si para a construção dos documentos solicitados, adotando entre si uma postura cooperativa perante a situação exposta. A aprendizagem de atitudes, quanto às atividades grupais, exige que o aprendiz se reconheça como um membro do grupo, incumbido de atuar na tentativa de resolver os problemas, tomando um papel oposto à individualidade e a competição. Não se trata de apenas um indivíduo fazer a tarefa do grupo todo, mas sim de traçar meios e formas para que todos possam participar de forma efetiva e significativa (POZO; CRESPO, 2009; WARD, 2010).

Após essa etapa, o pibidiano P5 solicitou que a turma, em conjunto, utilizando os dados já registrados na lousa, elaborasse um único documento de cada uma das modalidades já apresentadas. Ao propor isso, alguns estudantes se disponibilizaram para ir ao quadro construir tais documentos (Figura 10).

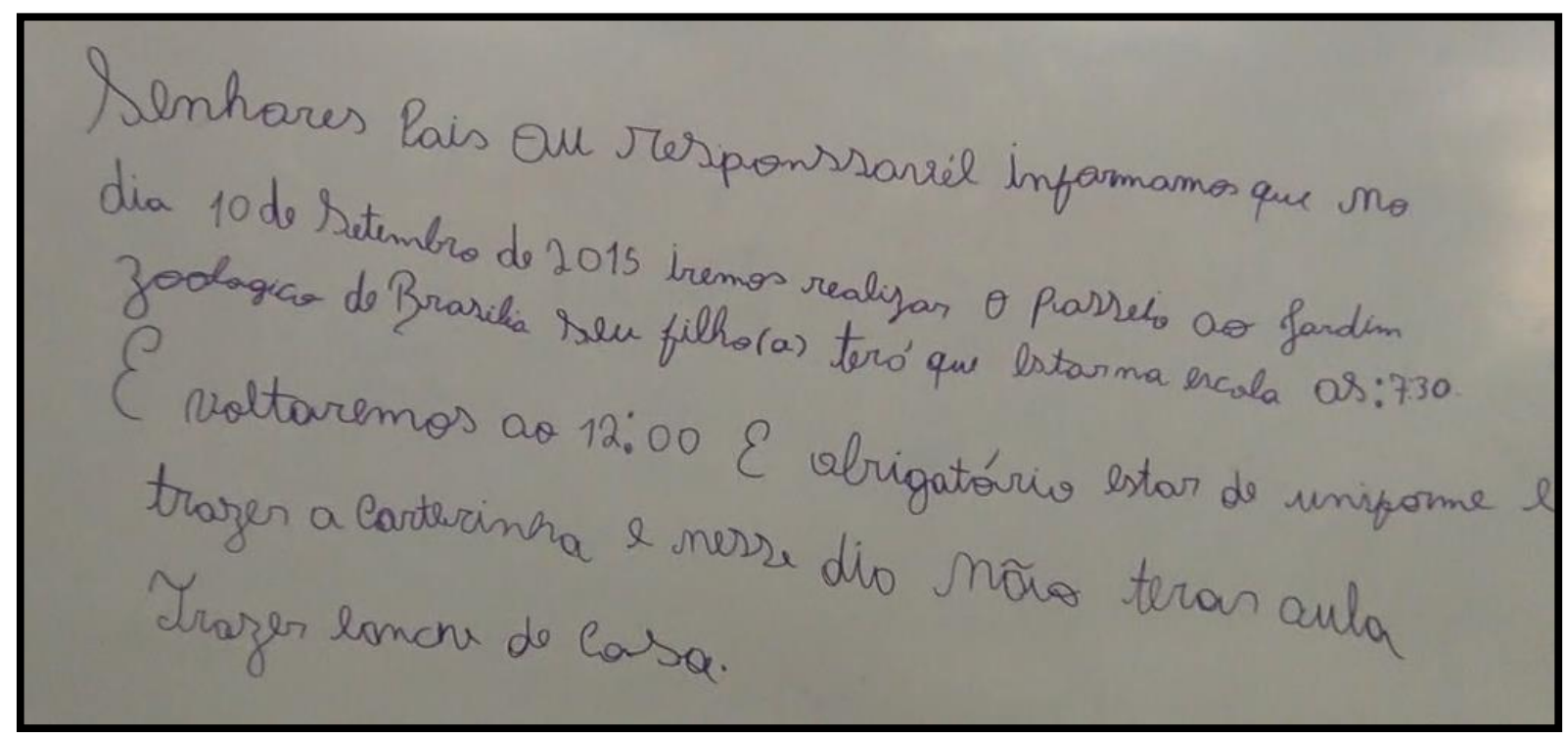

Figura 10- Parte do bilhete construído pelos alunos, solicitando a autorização dos responsáveis para a futura saída de campo. 
A atividade proposta favoreceu a grandeza coletiva, uma vez que os estudantes cooperaram para resolução de um problema, mesmo este não sendo de cunho científico. Essa tarefa permitiu que os interagissem entre si, pensando, refletindo, explicando ideias e debatendo, apresentando uma característica evidente do âmbito investigativo (AZEVEDO, 2004).

Para finalizar o encontro, foi lançada a seguinte questão investigativa: "Qual é a importância das serpentes no seu dia-a-dia"? Os discentes registraram no diário de campo vários itens relativos à indagação exposta:

"Para ela comer os ratos e quando você é picado por ela você vai para o hospital eles são um soro feito com o próprio veneno da cobra. E o veneno da cobra é usado para fazer remédio”. (A2)

"Elas deixam a cadeia alimentar mais equilibrada, porque ela come os coelhos e os ratos". (A9)

"Eu acho importante para nosso meio ambiente para que nós ajudem a remover ratos animais que prejudicam nossa saúde. Elas comem os ratos e nem todas as serpentes tem veneno”. (A14)

"Sim, porque ela como o ovo e coloca as cascas para fora e isso ajuda no adubo dos pé de jabuticaba e outro. Obrigado cobra por fazer crescer o meu pé de jabuticaba, eu vi isso na TV com meu pai que eu e ele gostamos de assistir programa de bicho”. (A16)

Nos argumentos apresentados, infere-se que os educandos, citados anteriormente, reconheceram a relevância das serpentes para o cotidiano, apesar de atribuírem aos ratos apenas um papel patogênico, demonstrando uma visão antropocêntrica em relação a esses seres. Assim, é interessante trabalhar questões desse âmbito, posto que, geralmente, a maneira como o aluno concebe tal animal, vai interferir na forma como este vai tratar esse ser vivo, aprisionando-o, matando-o ou até mesmo acariciando-o (OLIVEIRA; SOUZA, 2014).

No entanto, a luz da mobilização dos procedimentos, destaca-se o desenvolvimento/demonstração da compreensão e organização conceitual da informação, visto que foi atribuído o estabelecimento de relações conceituais ao correlacionarem a importância das serpentes com conhecimentos referentes à ecologia, temática trabalhada no âmbito das aulas de ciências desse ano.

Após os discentes evidenciarem seus conhecimentos referentes à questão proposta no diário de campo, como tarefa para casa solicitou-se que os mesmos realizassem uma 
entrevista com os responsáveis para averiguar as ideias deles no tocante a importância das serpentes, com o intuito de promover um processo de troca de informações.

\subsection{4 - $4^{\circ}$ Encontro (02/09/2015) - Atividade Prática: Conhecendo as Cascáveis e Refletindo sobre a Importância das Serpentes}

Os pibidianos que ministraram esse momento foram os P4 e o P5 e a professora supervisora realizou registros dos acontecimentos do dia e das ações dos aprendizes. Com o desenrolar dos encontros, percebeu-se a mudança de postura no aspecto comportamental e organizacional das atividades propostas, demonstrando atitudes em relação à aprendizagem da ciência, principalmente no que diz respeito à conduta. No que tange aos procedimentos de comunicação da informação e no ato de desenvolver/demonstrar formas de investigar, também houve uma aparente melhoria. Tais fatores podem ser ressaltados nas expressões dos pibidianos $\mathrm{P} 4$ e P5, respectivamente:

"Durante todo o minicurso se nota uma melhora no comportamento dos alunos ao longo das aulas, um comprometimento maior, organização por parte dos alunos”. (P4)

"O mais curioso foi à evolução dos alunos, melhoraram a desenvoltura nas apresentações orais, estão cada dia mais questionadores e ao mesmo tempo em que questionam eles mesmos já buscam as respostas”. (P5)

Esse êxito pode ser atribuído à transferência de responsabilidade que foi trabalhada ao decorrer dos encontros, onde os estudantes desenvolveram capacidade ativa e esforço para sanar as suas próprias indagações e questionamentos, buscando novos meios de pesquisa, dialogando com os seus colegas e comunicando as ideias construídas, diferentemente do que comumente é empregado na maioria das aulas de ciências que focam no ato do aluno [...] "memorizar uma longa lista de fatos, muitas vezes nomes exóticos e pomposos" (BIZZO, 2009, p. 15).

A primeira atividade desenvolvida nesse encontro foi referente à comunicação da entrevista realizada pelos alunos sobre a importância das serpentes no dia-a-dia, que havia sido solicitada no encontro anterior. Em relação à questão proposta, o aprendiz A14 afirmou que: 
"A minha mãe disse que não tem importância nenhuma, mas eu discordo e a minha resposta é que ela come o ovo coloca para fora e ajuda no adubo das plantas, para elas crescerem". (A14)

Nessa expressão, verifica-se uma atitude crítica e reflexiva em relação à ciência, visto que o mesmo apresentou argumentos contrários e cabíveis à opinião da pessoa entrevistada, confrontando ideias, mostrando que existem outros caminhos para chegar a dado resultado. Esse tipo de atitude pode ser desenvolvida/demonstrada quando o professor encara o ensino como algo construtivo, inserindo em sua prática diária problemas qualitativos, de âmbito aberto, considerando que estes são instrumentos oportunos para que os estudantes discutam sobre suas ideias, debatam com seus colegas e cooperem entres grupos, além de propiciar a tomada de decisões (POZO; CRESPO, 2009). Desse modo, ressalta-se novamente a importância do docente planejar atividades para tal dimensão, tendo em vista que um recurso didático por si só não é capaz de desenvolver tais tipos de atitudes, sendo necessária a ação estratégica do educador, para que tal atitude seja formada ou manifestada.

Já o aluno A9 não fez a pesquisa com o responsável, mas utilizou o ZooMapsBrasília como ferramenta de busca, e salientou que:

"Elas são importantes na cadeia alimentar, e ela come rato e sem elas teria muitos ratos nas casas e nas chácaras". (A9)

Com essa fala, verifica-se o aparecimento de procedimentos de busca e captação da informação, pois o estudante foi ao encontro de novos meios de pesquisa para solucionar a questão, havendo também o estabelecimento de relações conceituais, visto que, mais uma vez, foi ressaltada a temática de cadeia alimentar. Dessa forma, infere-se que em relação a esses tipos de procedimentos, os alunos vêm tornando-se mais autônomos e estratégicos, já que eles têm um controle mais consciente sobre estes, caminhando de forma mais progressiva para uma aprendizagem construtiva (POZO; CRESPO, 2009; POZO; MONEREO; CASTELLÓ, 2001).

$\mathrm{Na}$ dimensão atitudinal, houve ocorrência principalmente de atitudes em relação à ciência, tendo em vista que o pibidiano P4 relata em seu discurso o aparecimento de aspectos motivacionais: 
"O aprendiz A2 além de fazer a atividade, fez uma pesquisa enorme sobre cobras, sobre a importância, as venenosas... ele demostrou grande interesse”. (P4)

O pibidiano P5 complementa o dado, afirmando em seu relatório que:

"Alguns alunos fizeram pesquisas além do que foram solicitadas, todas as informações foram anotadas no caderninho de campo. Eles estão bem curiosos em relação ao tema proposto e demonstrando muita autonomia na hora de pesquisar a respeito das dúvidas que eles tinham”. (P5)

Conforme Pozo e Crespo (2009, p. 40), a motivação é um fator extremamente importante para o crescimento intelectual do aluno, posto que "sem motivação não há aprendizagem escolar, dado que o aprendizado, pelo menos o explícito e intencional, requer continuidade, prática e esforço, é necessário ter motivos para se esforçar”.

A ação do aprendiz A2 demonstrou um grande comprometimento, curiosidade e interesse, visto que não foi solicitada a realização da pesquisa e, apesar disso, o mesmo não poupou esforços para efetuá-la. Além do mais, verifica-se também que com essa situação foram desenvolvidos/demonstrados procedimentos de seleção, busca e captação da informação e formas de fazer perguntas, pois em um momento anterior o aprendiz A2, registrou no seu diário de campo algumas questões e depois efetuou uma pesquisa para sanar as suas dúvidas:

"Como a cobra troca de pele? O processo de troca de pele é chamada de ecdise isso dura em média 13 dias e elas tem que esta com água fresca e totalmente limpa e entram na água para perder a pele a antiga”. (A2)

"Quantas cobras existem no Brasil? No mundo existem por volta de 2930 espécies cobra e serpentes. O Brasil abriga 321 aproximadamente 10\%”. (A2)

Assim, infere-se que o discente incorporou a sua rotina o hábito de propor problemas e resolvê-los por si só. Nesse sentido, a resolução de problemas torna-se um artifício autônomo e espontâneo quando o aluno tem a atitude de procurar meios para fomentar a resolução de suas próprias perguntas, habituando-se a questionar ao invés de apenas esperar perguntas prontas (ECHEVERRÍA; POZO, 1998). 
Em relação à atividade prática, foram lançadas duas questões investigativas: "Você já viu uma cascavel? Como é uma cascavel?” Após isso, os educandos discutiram acerca do assunto e registraram no diário de campo suas ideias prévias. Posteriormente, foi exibida para a turma uma cascavel preservada no formol. Ao visualizarem a amostra, houveram momentos de muita euforia e entusiasmo entre eles, onde emergiram várias dúvidas e indagações:

O aluno A 21 perguntou para a professora-supervisora:

"Professora, é uma cascavel?". (A21)

O aluno A10 respondeu conscientemente:

"Sim, olha o chocalho". (A10)

E o discente A2 complementou:

“Cada bolinha do chocalho da cascavel significa uma troca de pele”. (A2)

Outros aprendizes questionaram:

“A cascavel só tem dessa cor?”. (A15)

"Ela pode crescer mais ou ficar menor?". (A15)

Nessas expressões, constatam-se procedimentos de aquisição da informação, posto que a observação foi o elemento crucial para o surgimento de perguntas (Figura 11). Ao construírem essas indagações, nota-se um procedimento de análise da informação e realização de inferências, uma vez que foram desenvolvidos/demonstrados modos de fazer perguntas no aluno A15. E ainda, enaltece-se uma atitude em relação à aprendizagem da ciência, considerando que A2 mostrou um enfoque profundo ao apresentar significado dos anéis do guiso da serpente exposta.

De acordo com Carvalho (2013), em uma investigação é essencial que ocorram diferentes tipos de interação, seja entre os indivíduos, entre as pessoas e suas ideias prévias e entre os seres e os objetos. A investigação implantada favoreceu o desenvolvimento de tais interações, já que possibilitou que os discentes explorassem suas ideias prévias, interagissem com o objeto em estudo por meio da observação, permitindo ainda, a formulação de questões novas e a troca de ideais entre os colegas. 


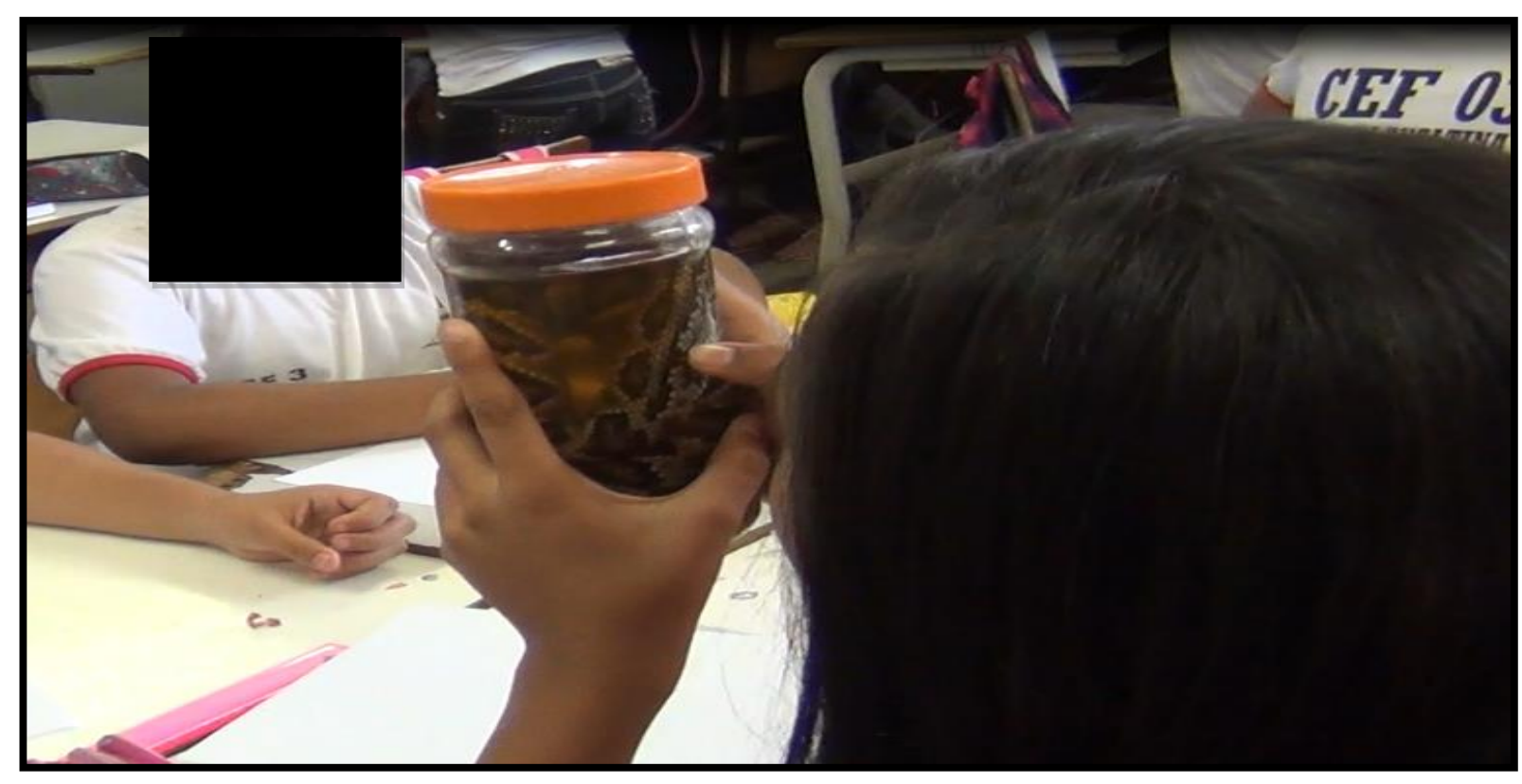

Figura 11- Estudante observando a cascavel utilizada na atividade prática.

Um caso notório emergiu quando determinado aprendiz incorporou em sua ação, estratégias sugeridas pelos próprios pibidianos ao decorrer dos encontros:

O aprendiz A13 perguntou:

“Que liquido é esse que está dentro do pote?”. (A13)

O aluno A4 sugeriu:

“Anota no caderno”. (A4)

O educando A6 respondeu:

"É formol”. (A6)

$\mathrm{O}$ ato do aluno A4 sugerir que o aluno A13 anotasse no caderno a sua dúvida, mostra um procedimento aquisição da informação, tendo em vista que o aluno A4 explicitou uma estratégia para que A13 pudesse buscar e sistematizar a informação, vislumbrando uma prática que foi bastante realizada no decorrer dos encontros, considerando que sempre que iam surgindo algumas dúvidas, os aprendizes eram guiados a anotarem no diário de campo para efetuar uma pesquisa posterior, no intuito de erradicar a indagação. Salienta-se também que o aprendiz A14 também adotou um modelo de atitudes.

De acordo com Pozo e Crespo (2009, p 33), [...] “o aluno, durante a aula de ciências, pode imitar o professor na forma de resolver uma dúvida ou planejar uma pesquisa indagando por si só" [...]. Assim, enfatiza-se que por meio dessa interação social, os 
estudantes tendem a aceitar e a incorporar em seu aprendizado, modos equivalentes aos modelos que recebem, conforme aconteceu no relato explicito anteriormente, onde os discentes adotaram estratégias utilizadas pelos pibidianos.

Após a observação, os aprendizes foram orientados a registrarem no diário de campo as estruturas anatômicas da espécie em amostra. Um desenho que mereceu destaque foi o elaborado pelo aprendiz A9 (Figura 12).

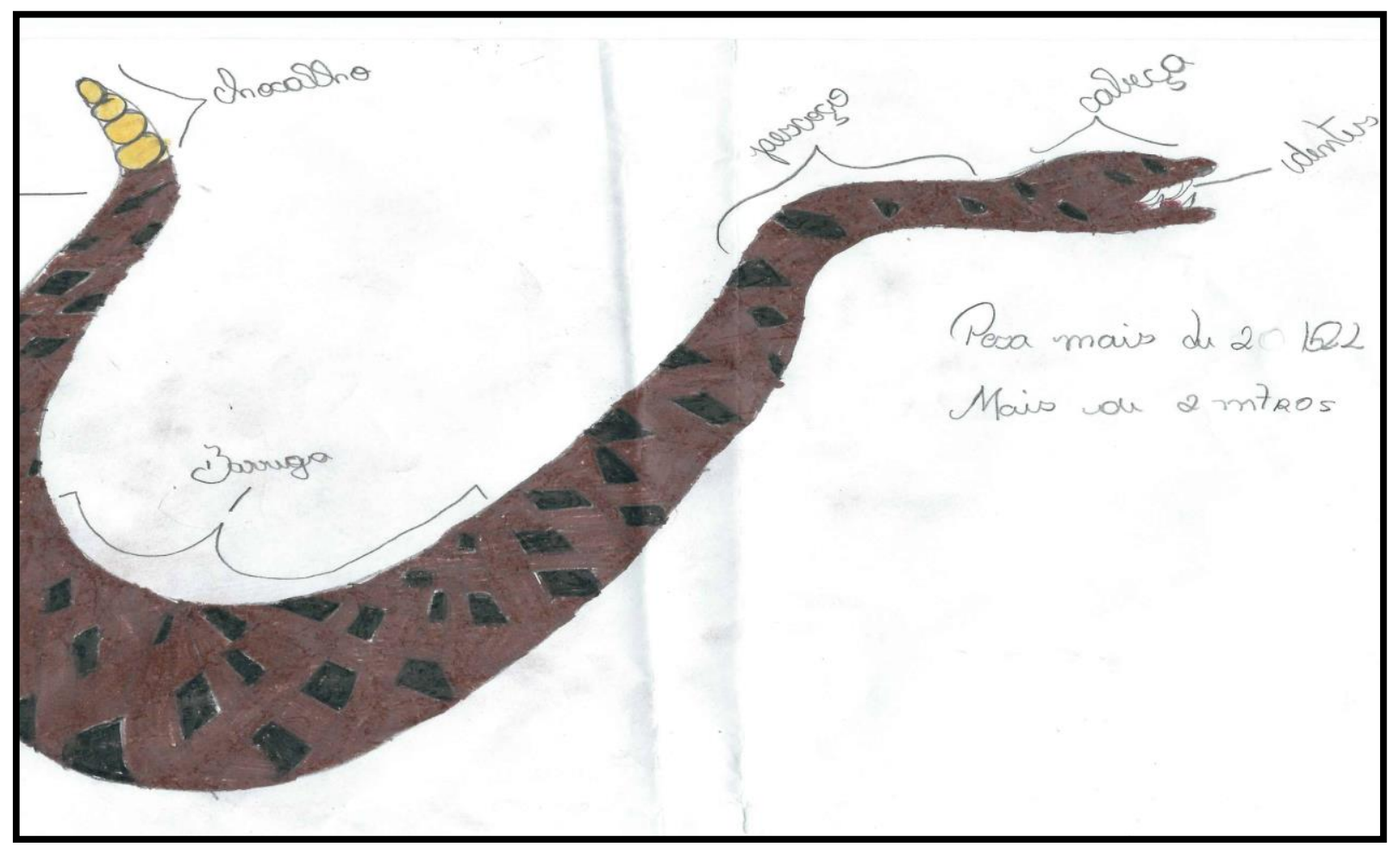

Figura 12 - Desenho do Aluno A9 construído por meio do procedimento de observação.

Além de apresentar elementos referentes à morfologia da serpente observada, o mesmo expõe dados induzidos por meio de mecanismos de observação, modelização e manipulação do material, mostrando o desenvolvimento/demonstração de procedimentos de aquisição e interpretação da informação.

A aquisição de tais procedimentos foi originada pela observação. Esse procedimento possui uma ampla relevância para o aprendizado, uma vez que propicia que os discentes explorem a natureza dos objetos, adquiram noções de classificação e separação, além de promover o pensamento científico e o desenvolvimento mais amplo do conhecimento (WARD, 2010).

No final do encontro, os educandos ressaltaram a importância da elaboração de crachás para identificá-los, propendendo elevar a segurança, caso ocorresse algum imprevisto 
na saída de campo. Assim, eles evidenciaram que seria essencial elucidar no material alguns dados específicos, como endereço, telefone, nome completo, dentre outros (Figura 13).

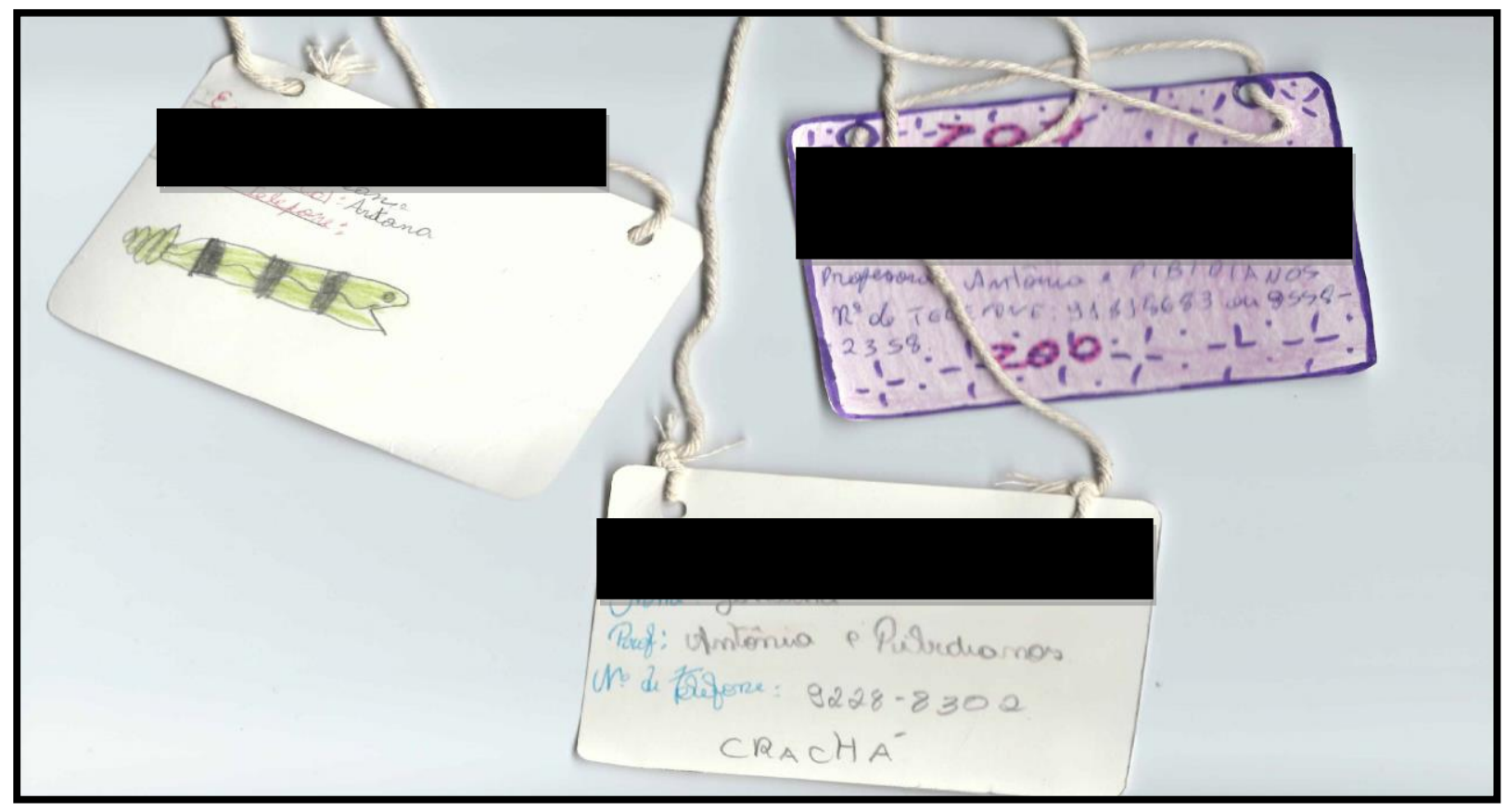

Figura 13- Alguns crachás construídos pelos educandos do minicurso.

Assim, o pibidiano P4 explicitou que:

"Essa atividade foi uma ideia que partiu dos próprios alunos, eles decidiram o que deveria conter no crachá, como deveriam enfeitar." (P4)

Essa intervenção mostra um processo criativo por parte dos alunos, já que estes conseguiram interferir positivamente no planejamento do minicurso. Isso mostra que as atividades propiciaram que os estudantes saíssem da sua "zona de conforto" e fossem ao encontro de um conhecimento mais significativo e relevante, rompendo com a aprendizagem acumulativa, uniformizadora e transmissiva e, colocando estes como protagonistas do saber (ZABALA, 1998).

Nesse encontro, apareceu uma nova atitude em relação à aprendizagem da ciência, enfoque profundo, conforme a análise realizada, que ainda não tinha sido desenvolvida/demonstrada. Assim, destaca-se que quando os aprendizes estão em contato constante com situações problemas, os diferentes tipos de atitudes vão manifestandose/formando-se de forma gradual (POZO; CRESPO, 2009). 


\subsection{5 - 5 Encontro (10/09/2015) - Visitando o Serpentário do Zoo de Brasília-DF}

Ao decorrer de todos os encontros, foram aplicadas diversas atividades visando à preparação dos estudantes para a visitação ao serpentário. Dessa forma, a história do Zoológico de Brasília-DF foi explorada, ocorreram momentos de pesquisa e comunicação de resultados, houve a manipulação do aplicativo ZooMapsBrasília, a construção de desenhos, mapas e bilhetes, etapas de observação, formulação de questões, dentre outros. Todos esses elementos forneceram aportes para que os aprendizes encarassem a saída como uma atividade orientada, sistematizada e com objetivos, ao invés de um simples "passeio". Corroborando com essa ideia, Marandino, Selles e Ferreira (2009, p. 144) afirmam que "deve-se ter clareza nos objetivos ao levar os alunos a visitas a campo, para que essa atividade não se banalize e tenha seu potencial reduzido".

As saídas a campo propiciam diversos ganhos, tanto na dimensão afetiva quanto na aprendizagem de conceitos, procedimentos e atitudes. "A convivência em grupo, a necessidade de organização individual, de ajuda mútua, de enfrentamento de desafios até mesmo físicos certamente mobilizam conhecimentos diferenciados, os quais são específicos desse tipo de atividade (MARANDINO; SELLES; FERREIRA, 2009, p. 146).

Partindo dessas considerações, um dos objetivos primordiais dessa visitação ao serpentário era que os estudantes se apropriassem do serpentário presente no Zoo-DF, como um instrumento de pesquisa, que possibilitasse a observação, formulação de hipóteses, seleção e comparação de informações, além de fornecer meios para a construção de conhecimentos e a mobilização de motivações, desenvolvendo as atitudes e os procedimentos, principalmente, conforme vem sendo explorado ao decorrer de todos os encontros.

Assim sendo, a ida ao serpentário foi um momento de bastante entusiasmo e motivação para os aprendizes e para os pibidianos também, uma vez que todos decidiram participar da saída. Ao entrarem no ônibus, os alunos foram logo buscando o mapa confeccionado para consultar a rota escolhida pelo motorista e os pontos de referências. Com isso, evidencia-se o desenvolvimento/demonstração do primeiro procedimento de aquisição da informação, visto que os estudantes utilizaram o meio cartográfico para buscar informações que propiciassem a localização espacial destes, tendo em vista que esse tipo de procedimento é capaz de auxiliar o aluno até mesmo na leitura do próprio mapa, já que fornecem meios para que estes selecionem informações importantes (ROMANO, 2011). Ao buscar tais informações, os aprendizes também aplicaram tais conhecimentos para comparar o 
mapa com o percurso realizado, estabelecendo relações conceituais. E ainda, desenvolveram atitudes, posto que ações colaborativas e cooperativas foram manifestadas, quando ocorreu a divisão do trabalho, pois enquanto um aluno observava o caminho, os outros marcavam no mapa a localização ou o ponto de referência pelo qual passavam.

Ao chegarem ao Zoo, os educandos mostraram-se bem animados, curiosos e questionadores. Logo, foi realizada uma divisão dos alunos em grupos, no intuito de dinamizar o processo, assim cada pibidiano ficou responsável por uma equipe. Desse modo, os alunos não foram instruídos em relação à trajetória de chegada ao serpentário, já que a intenção era permitir que os mesmos selecionassem os procedimentos mais adequados para realizar tal tarefa.

E assim, essa etapa obteve êxito, visto que os aprendizes utilizaram instrumentos como a placa com o mapa do Zoo e o ZooMapsBrasília para se orientarem até o serpentário. Isso mostra, novamente, o aparecimento de um procedimento de busca, captação e seleção de informações, tendo em vista que utilizaram os dados científicos presentes nos materiais para atingirem o objetivo estabelecido. Tal fator evidencia que os aprendizes assumiram o domínio estratégico, ficando cada vez mais "sozinhos" diante do problema, mostrando que os pibidianos conseguiriam transferir progressivamente o controle das tarefas para estes (POZO; CRESPO, 2009).

No serpentário, foi instaurado o momento "Tira dúvidas". Nesse instante, os educandos tiveram a oportunidade de explorar o ambiente e sanar algumas das dúvidas que foram levantadas ao decorrer dos encontros anteriores e que ainda não tinham sido resolvidas. Assim, foram percebidos diversos tipos de procedimentos, tendo em vista que foram desenvolvidos/demonstrados:

a) Aquisição da informação: observaram as serpentes dispostas, leram as informações presentes nas placas informativas e ainda questionaram o vigilante do espaço em relação às questões explicitadas em um encontro anterior. Assim, ficou notória a mobilização de procedimentos de observação, seleção, busca e captação da informação (Figura 14).

b) Compreensão e organização conceitual da informação: ao olhar uma cascavel no serpentário aluno A17 afirmou que "essa cobra é venenosa, pois tem fosseta loreal" (A17). Por meio da observação, outro tipo de procedimento, o discente A17 conseguiu mostrar que aprendeu uma das características para identificar se uma determinada 
serpente é peçonhenta ou não, isso evidencia um procedimento voltado para o estabelecimento de relações conceituais. Houve revisão e memorização da informação, quando o estudante A2 respondeu ao vigilante que ocorreria uma competição intraespecífica se fosse colocada um macho a mais no local aonde tinham casais de cascavéis, uma vez que A2 lembrou-se de um conceito estudado anteriormente.

c) Análise da informação e realização de inferências: os aprendizes desenvolveram formas de investigar ao construírem alguns questionamentos, como: "As cobras também comem folhas?" (A6); "A píton pode ser criada em casa?” (A2); "A boca da cobra chega até quantos metros para engolir pessoas?" (A7); "Como as cobras fazem para se reproduzir?" (A7); "Quantas trocas de pele a cascavel faz no ano?" (A16) e tentarem solucioná-los mediante o diálogo com o vigilante.

d) Interpretação da informação: ocorreu um procedimento de tradução da informação quando o educando A10 auxiliou o A2 compreender o conceito de vivíparas. Ressaltase também a manifestação de uma atitude cooperativa.

e) Comunicação da informação: expressão oral ocorreu com frequência, pois da mesma forma que o vigilante abordava alguns assuntos com os alunos no intuito de sanar dúvidas e mostrar curiosidades, os mesmos explicitavam os conceitos construídos no decorrer dos encontros. Também houve a manifestação outros tipos de expressão, já que os mesmos desenharam no diário de campo algumas espécies de serpentes e suas determinadas características para discutir sobre a relação formato da pupila $\mathrm{x}$ atividade dos animais e formato da cabeça x peçonha.

Em relação a essa etapa, o pibidiano P5 ainda destacou que:

"É visivel, o quanto os alunos conhecem a respeito dos animais e como é importante que sejam instigados a pesquisar, nos primeiros encontros eles poucos respondiam aos questionamentos, na visita ao zoo eles nem precisavam ser questionados, as dúvidas iam surgindo e eles iam procurando respostas de imediato”. (P5)

Esse argumento evidencia o desenvolvimento que os aprendizes tiveram ao decorrer do minicurso, considerando que nesse momento eles já estavam em constante trabalho investigativo. Assim, cabe ressaltar a relevância desse tipo de atividade, considerando que a capacidade de refletir, planejar e tirar conclusões subsidia a criança a pensar, escolher, 
classificar, raciocinar, sendo esses alguns elementos importantes para a constituição de uma mente democrática, diferentemente de um ser passivo, inerte e conformista (ZABALA, 1998).

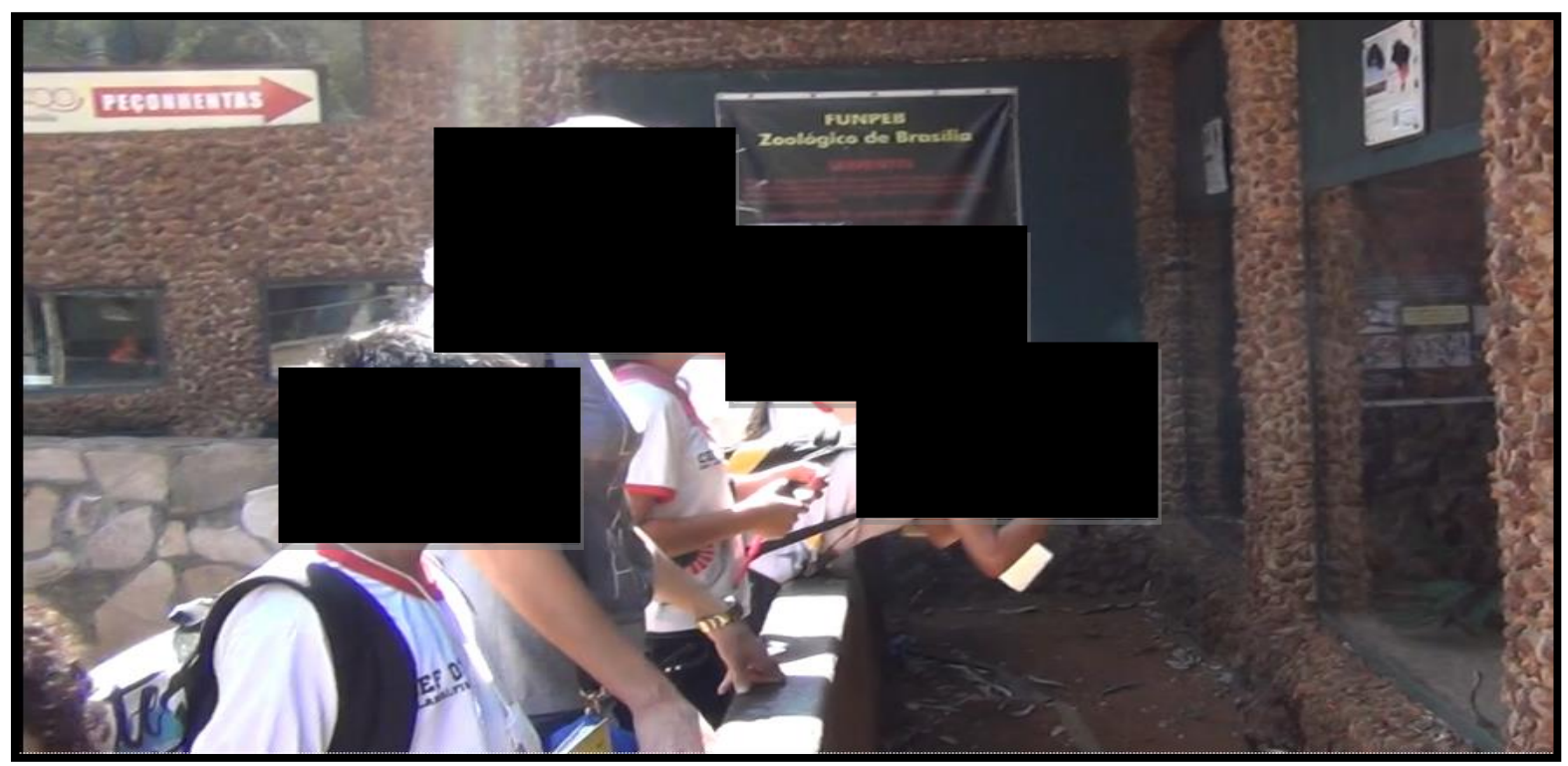

Figura 14- Alunos realizando procedimento de observação.

Além dos procedimentos, visualizou-se também a formação de alguns tipos de atitudes nos alunos, principalmente no que diz respeito à ciência, visto que aspectos motivacionais foram observados quando os discentes chegaram ao serpentário e logo foram correndo para indagar, registrar, não mostraram-se dispersos e estavam ativos nas atividades propostas. Assim, os pibidianos $\mathrm{P} 3$ e $\mathrm{P} 4$ ressaltaram que:

"Foi incrivel ver a empolgação e comentários deles ao longo da visita, onde traziam curiosidades e informações interessantes acerca das serpentes”. (P3)

"Eles observarem o serpentário, eles ficaram animadas, o mais incrível é que eles começaram a explicar, falar curiosidades sobre as cobras, elas conseguiam visualizar as cobras e me mostravam onde estavam (eu não conseguia achar as cobras)”. (P4)

Como já discutido anteriormente, a motivação é a alma da aprendizagem e o papel do educador diante deste fator é tornar-se o favorecedor e dinamizador da participação dos alunos, estabelecendo desafios e artifícios para que a atenção destes seja mantida (ZABALA, 1998). A ida ao serpentário foi um momento que motivou os alunos para o novo, eles viram nesse espaço um ambiente de aprendizagem e não somente de lazer e entretenimento. 
Um fator interessante a ser relatado, foi a interação que ocorreu entre os educandos e o vigilante do local. Esse homem possuía vários conhecimentos acerca das serpentes, que segundo ele, foram construídos pelo cotidiano e com a sua experiência. Logo, curiosamente o aprendiz A5 questionou:

\section{“Você estudou para esse trabalho?”. (A5) \\ $\mathrm{O}$ vigilante respondeu: \\ "Não, a gente aprende com o dia-a-dia".}

Esse diálogo mostra o aparecimento de atitudes em relação à ciência, em que o discente A5 exprime uma preocupação pelas informações expostas pelo vigilante, evidenciando gosto pelo rigor e precisão no trabalho e ao mesmo tempo uma atitude crítica e reflexiva.

Apesar do desenvolvimento/demonstração das atitudes explicitadas anteriormente, salienta-se que o aparecimento de procedimentos tem sido mais perceptível nos encontros do que os conteúdos do âmbito atitudinal. Esse fator corrobora com os ensinamentos de Pozo e Crespo (2009), posto que estes fazem uma analogia aos estados da matéria para tratar dos tipos de conteúdos, afirmando que os procedimentos são como os líquidos, tendem a se misturar, podem-se separar por meio de certas técnicas, acomodam a forma do recipiente, já as atitudes seriam os gases, mesmo que não sejam fáceis de serem percebidos, estão em todo o meio, estão em todos os vãos do currículo, são dificilmente fragmentadas, talvez por isso seja mais complicado avaliá-las e separá-las.

Após o momento “Tira Dúvidas”, foram explicitadas as seguintes questões para os educandos: "As serpentes possuem o mesmo formato das cabeças? Todas elas são peçonhentas?". Outra vez, os alunos utilizaram procedimentos de observação e busca e captação da informação. Eles desenharam, anotaram dados no caderno para responder as indagações propostas. Nesse sentido, cabe ressaltar que em um momento posterior, no outro encontro, as informações registradas foram debatidas e expostas em um intercâmbio de comunicação.

Ao terminar de expressar as suas opiniões acerca das questões, os estudantes foram encaminhados para uma área do Zoo que possui uma sucuri (Eunectes murinus). Ao chegar lá, o aluno A7 já foi logo explicitando: 
A professora supervisora questionou:

"Como você sabe? Aonde você buscou essa informação?"

$\mathrm{O}$ discente $\mathrm{A} 7$ respondeu:

"Ela mordeu um policial e precisou de 10 homens para abrir a boca dela, ela não é venenosa, mas têm bactérias agressivas na boca, eu vi no animal planet”. (A7)

Nessa fala, pode-se observar o aparecimento de atitude voltada para a motivação e um procedimento de busca, captação e comunicação da informação. Assim, nota-se que as atitudes e os procedimentos podem aparecer de maneira integrada, juntamente com os conceitos, eles sobrepõem-se e constroem-se no processo de ensino aprendizagem (POZO; CRESPO, 2009).

Para finalizar o encontro, os educandos tiveram a oportunidade de tocar/segurar uma serpente, a cobra do milho (Elaphe guttata). Esse contato com o objeto em estudo propiciou que os discentes pudessem extrair da serpente diversas características por meio da proximidade construída entre os seres. Além do mais, este fato ocasionou diversas reações: medo, ansiedade, curiosidade e inquietação e ganhos de aprendizagem para os alunos, conforme os pibidianos P6 e P4 explicitam:

"Tivemos a oportunidade do zootoc, onde tivemos contato com uma cobra, isso para as crianças foi muito encantador, ficaram inquietas, e todos tocaram em uma cobra, a cobra não era venenosa, mas tivemos um cuidado extremo com as crianças”. (P6)

"No geral essa parte da visita foi extremamente importante, pois com ela os alunos tiverem um contato físico com a serpente e foi possível através disso diminuir alguns préconceitos que eles tinham”. (P4)

Com a saída de campo, constatou-se que o potencial didático pedagógico do Zoo, especificamente no que diz respeito ao serpentário para o ensino de ciências, ao oportunizar para o aluno o poder de expressar suas falas, concepções, dúvidas, sensações e compartilhar ideias, ao invés de somente ouvir a explicação de monitores/professores, processo expositivo que, provavelmente, não contribuiria para o desenvolvimento/demonstração de procedimentos e atitudes (MARANDINO; SELLES; FERREIRA, 2009). 


\subsection{6 - $6^{\circ}$ Encontro (16/09/2015) - Retornando ao Espaço Formal: Divulgando Resultados e Discutindo sobre Acidentes Ofídicos}

Considerando que o minicurso perpassou por um processo de planejamento, ao retornar ao espaço-formal, optou-se pela comunicação e organização dos dados obtidos mediante a visitação, entendendo que esse processo é importante, uma vez que ações a [...] "serem desenvolvidas não podem restringir-se à saída ao campo. É importante que o professor inclua no seu plano o desenvolvimento de atividades de preparação e, ao voltar, a discussão das observações e dados coletados para a sistematização de conhecimentos” (BRASIL, 1998, p. 126).

Assim, uma das primeiras atividades retomadas foram referentes às questões inseridas na saída ao serpentário, que devido à falta de tempo não haviam sido discutidas ainda. Mediante a esse fator, no intuito de auxiliar, o pibidiano P1 utilizou uma estratégia interessante para possibilitar que os aprendizes sistematizassem o conhecimento construído.

Dessa forma, o mesmo solicitou que os alunos transpusessem para o quadro branco da sala os desenhos das serpentes construídos por eles. Após isso, eles foram discutindo se determinadas espécies eram peçonhentas ou não, conforme algumas características que definem tal fator. Com isso, o aluno A6 elaborou uma tabela para sistematizar alguns dados (Figura 15):

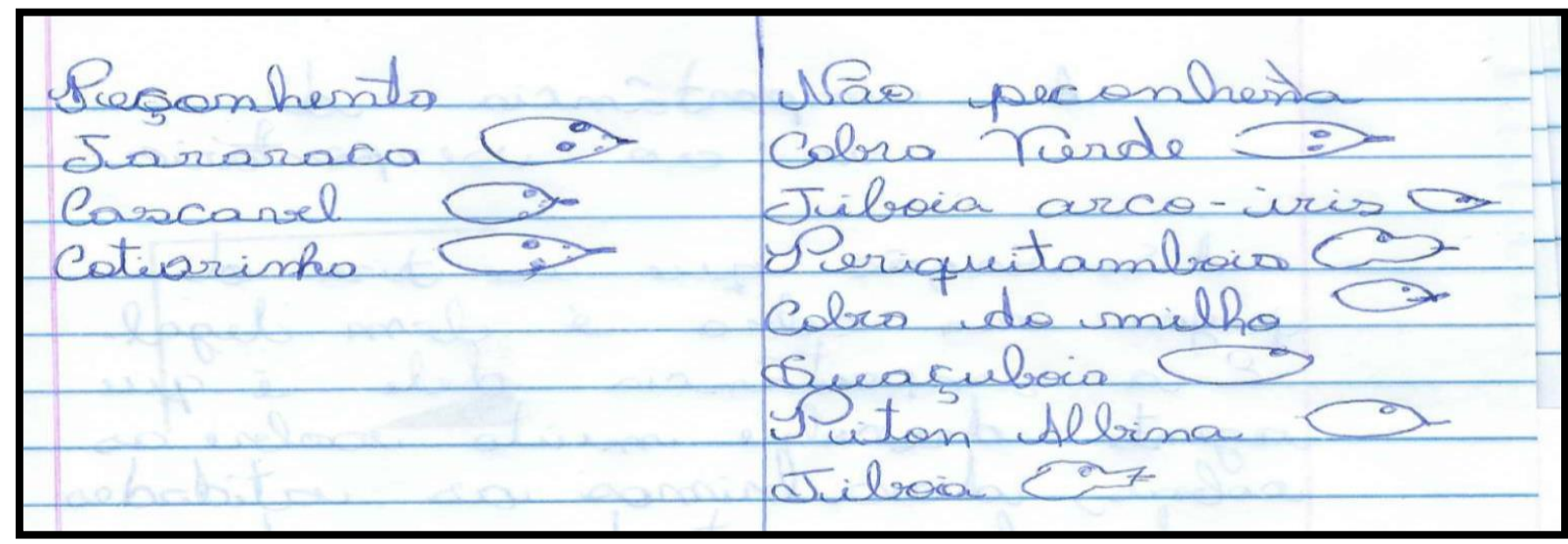

Figura 15 - Tabela apontando algumas espécies peçonhentas e não peçonhentas do serpentário de Brasilia -DF.

A construção desse elemento indica o desenvolvimento/demonstração de vários tipos de procedimentos, uma vez que A6 observou as características das espécies presentes no serpentário e nas placas informativas, modelizou alguns animais ressaltando a presença de 
fossetas em determinadas serpentes, comparou e selecionou dados para agrupar e definir as espécies em relação à peçonha. É interessante ressaltar que a observação direta das serpentes, juntamente com a leitura das informações, propiciou que os discentes coletassem dados e desenvolvessem/demonstrassem outros tipos de procedimentos, como exposto anteriormente. Além do mais, compreendendo a importância dessa ação, é função do docente desenvolver nos educandos essa capacidade de observação, inserindo atividades que "os motivem a buscar os detalhes de determinados objetos, para que o mesmo objeto seja percebido de modo cada vez mais completo e diferente do modo habitual” (BRASIL, 1998, p. 21). Salienta-se também que o ato de construir tabelas, que nesse caso foi iniciado pela observação, é um procedimento, que para ser concretizado, exige a movimentação de outros procedimentos, não sendo um exercício mecânico.

Depois, os alunos debateram sobre a questão da cobra coral (Micrurus lemniscatus), espécie que não apresenta fosseta loreal, mas é peçonhenta e relacionaram o formato da pupila ao horário que exerce suas atividades, em seu habitat. Ao decorrer da discussão, surgiram várias indagações por parte dos alunos, evidenciando formas de investigar sobre questões referentes à semi-peçonhenta e diferença entre a falsa coral (Oxyrhopus guibei) e a verdadeira (Micrurus lemniscatus). De acordo com Zabala (1998), ações como a expressão de ideias e formulação de questões são criadas quando o professor faz da sala de aula um ambiente favorável, que tem como prioridade principal a formação crítica e autônoma do aluno, em detrimento de processo verticalizado, embasado principalmente nos conhecimentos do educador.

Após a troca de informações, os estudantes foram orientados pelo pibidiano P1 a escreverem um texto que retratasse a ida deles ao serpentário do Zoo de Brasília-DF, propagando as suas impressões. Ao concluírem a proposta, os mesmos tiveram que apresentar suas anotações para toda a turma, fomentando um debate. Assim, o aluno A4 construiu uma atitude crítica e reflexiva ao abordar que:

"E também é bom a gente saber se a cobra é peçonhenta para se um dia ela estiver na nossa casa a gente está prevenido”. (A4)

Ao relatar tal fator, percebe-se que o aprendiz refletiu sobre a importância de conhecer a diferença entre serpentes peçonhentas e não peçonhentas para o cotidiano, evidenciando uma situação real. A inserção de atividades que permeiam a reflexão e a tomada de decisões 
devem considerar as experiências do estudante, orientando o seu pensamento para a interrogação do fenômeno em estudo (ZABALA, 1998).

Ao apresentar sobre a saída para o serpentário, os alunos relatavam o sentimento gerado ao tocar na serpente. No entanto, o aluno A6 esqueceu-se de explicitar essas sensações, mas o aprendiz A7 desenvolveu formas de fazer perguntas e, começou a questionálo:

"Você falou da cobra que você triscou? Fala assim se você gostou ou não, se quase morreu”. (A7)

Ao questionar e elaborar perguntas o aluno saiu da fase manipulativa e aproximou-se de um trabalho investigativo e, também entrou em um meio cooperativo, haja vista que as indagações possuíam o intuito de ajudar o colega no processo de comunicação oral da informação. Ao decorrer dos encontros, as atividades aplicadas potencializaram a postura colaborativa e solidária ao invés da competição (POZO; CRESPO, 2009; ZABALA, 1998).

Após as comunicações, os aprendizes receberam as histórias em quadrinhos que retratavam casos de acidentes ofídicos em dois ambientes: no urbano e no rural. Esses materiais contavam com uma questão: “O que fazer”? Imediatamente, os alunos A1 e A7, em conjunto, foram explicando os procedimentos a serem realizados:

\footnotetext{
"Quando você for picado por uma cobra não deve se mexer". (A1)

“E lavar com água e sabão”. (A7)

"E com cuidado para o veneno não se espalhar pelo corpo". (A1)

"E mais rapidamente se você se mexer”. (A7)

“É importante saber a espécie para usar o soro”. (A1)
}

Nessas transcrições, notam-se atitudes que vislumbram a cooperação e o enfoque profundo. Com o transcorrer das atividades, essas atitudes apareceram de forma estável e constante, os aprendizes não mediam esforços para organizar e construir, em conjunto, o conhecimento. A realização desse trabalho conjunto que foi desenvolvido reafirma para os alunos que o êxito de um implica no êxito de todos, fomentando a reciprocidade (ZABALA, 1998).

Cabe ressaltar, que apesar de determinados dados aparecerem supracitados em alguns momentos, os processos comunicativos, tanto de expressão oral quanto escrito, foram bastante 
expressados ao longo das atividades. Conforme Carvalho (2013), trabalhar com a desenvoltura das habilidades de comunicação são necessárias para uma enculturação científica, familiarizando os alunos com os mais diferentes tipos de linguagens existentes, posto que possui extremo reconhecimento o uso da argumentação, escrita e leitura para auxiliar estes a edificarem entendimentos de Ciências.

Para tarefa de casa, foi solicitado que os estudantes realizassem uma entrevista com os familiares ou amigos acerca de casos de acidentes ofídicos, especificando a parte do corpo atingida e a cidade satélite em que ocorreu tal fato.

\subsection{7 - $7^{\circ}$ Encontro (25/09/2015) - Relatos sobre Acidentes Ofídicos e Organização da Feira de Ciências}

O penúltimo encontro foi desenvolvido pelos pibidianos P3 e P5 e a professora supervisora fez a etapa de observação. No primeiro momento, como poucos alunos efetuaram a atividade proposta, os ministrantes organizaram os participantes, em grupos, para que todos pudessem discutir e, posteriormente, apresentar seus relatos para a turma.

No primeiro instante, já ocorreu o desenvolvimento/demonstração de atitudes em respeito à aprendizagem da ciência, pois o aprendiz A20 auxiliou A17 a relatar a entrevista realizada, mostrando novamente formas de solidariedade e cooperação, como já foi relatado em outros encontros.

No decorrer da atividade, surgiu um relato interessante onde o aluno A5 explicitou que já havia sofrido um acidente ofídico no meio rural e, afirmou que possui traumas e muito medo, apesar de reconhecer a importância das serpentes para o meio ambiente. Essa expressão mostra o desenvolvimento/demonstração de uma atitude crítica, considerando que o mesmo adotou uma postura reflexiva diante de um fato negativo vivido por ele.

Individualmente, os discentes foram expressando seus relatos e a cada momento, o pibidiano P5 procurava investigar se as concepções prévias dos alunos, em relação às serpentes, foram modificando-se com o decorrer dos encontros. Com isso, alguns alunos foram afirmando que:

“Eu tinha medo, eu já sabia que elas eram úteis para a natureza, mas elas são bem mais importantes do que eu pensava”. (A17) 
“Antes eu pensava que elas não eram importantes”. (A4)

As expressões demonstram que tais estudantes conseguiram (re) formular as suas concepções prévias referentes às serpentes, adotando um caráter mais reflexivo, por meio das intervenções realizadas ao decorrer do minicurso. Inserir essa ação no meio escolar foi importante para [...] "conscientizá-los sobre a importância de preservação das espécies e ecossistemas, ou pelo menos, evitar o conflito entre as populações naturais e espécies nativas" (LUCHESE, 2013, p. 10).

Um fato curioso que também emergiu nesse encontro foi quando o aluno A2 trouxe uma pesquisa realizada de forma autônoma por ele (Figura 16).

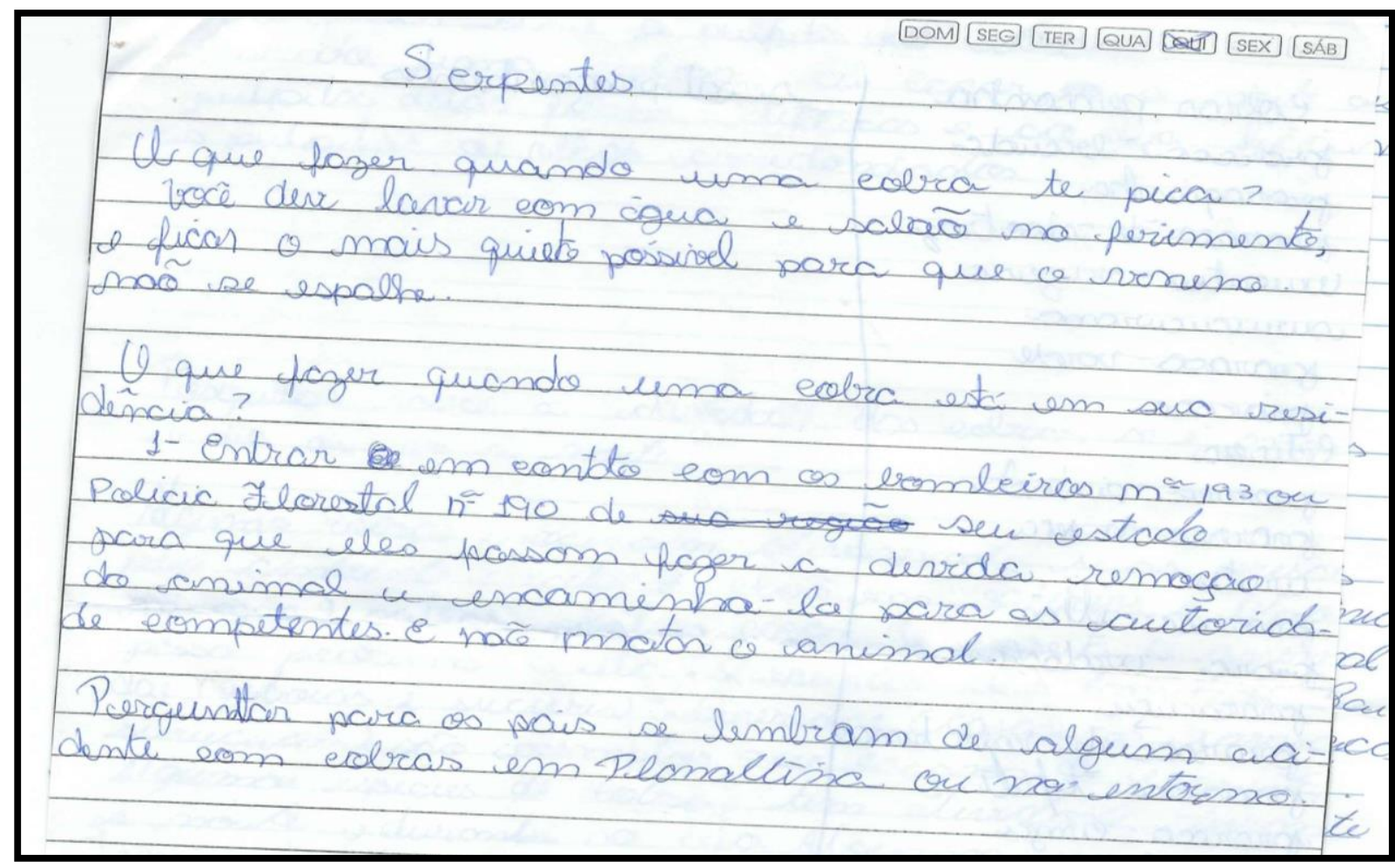

Figura 16 - Pesquisa realizada pelo aluno A2.

A pesquisa evidencia que o aprendiz desenvolveu formas de fazer perguntas, já que ele elaborou as próprias perguntas e ainda, procedimentos de seleção, busca e captação da informação. Houve também o aparecimento de atitudes de aspecto motivacional e de enfoque profundo. Nesse sentido, ressalta-se que a [...] "motivação pela ciência é descobrir o interesse, o valor de aproximar-se do mundo, indagando sobre sua estrutura e natureza, descobrir o interesse de fazer perguntas e procurar as próprias respostas" (POZO; CRESPO, 2009, p. 43). 
O minicurso auxiliou na ampliação da visão dos educandos acerca da classe das serpentes, por meio das atividades inseridas, no qual estes tinham total autonomia e liberdade para empenhar-se em busca do aprendizado, por meio de pesquisas, trocas de experiências e vivências com a família, com os colegas e mediante aos intercâmbios de comunicação. Além do mais, reforça-se que os pibidianos que mediaram o minicurso não forneciam respostas prontas para os discentes, mas davam suporte para que eles mesmos atuassem na formulação e resolução dos seus questionamentos. Assim, enaltece-se a importância de um docente que sistematize os conhecimentos gerados, não no intuito de "dar a resposta", mas de assumir o papel de crítico da comunidade científica (CARVALHO, 2010).

Um ponto interessante, destacado pelo pibidiano P5 e, que cabe discutir é o seguinte:

“A interação com a família foi algo fantástico. Em todo o minicurso os pais foram muito presentes auxiliando os alunos na busca por informações e compartilhando com eles as suas próprias experiências". (P5)

As atividades propostas permitiram a solidificação da conexão entre os conhecimentos familiares e os que estavam sendo abordados na escola, especificamente no que tange ao assunto voltado para serpentes. A parceria família-escola pode maximizar o desenvolvimento dos adolescentes, fomentando momentos de compartilhamento de experiências e até mesmo estabelecendo um vínculo mais afetivo (POLONIA; DESSEN, 2005).

Após as discussões sobre as entrevistas, iniciaram-se os preparativos para a feira de ciências. As temáticas a serem abordadas, os materiais utilizados e a formação dos grupos foram definidos pelos próprios educandos. Assim, o pibidiano P3 ressaltou:

"O mais legal foi que eles que tiveram as ideias do que vão fazer, como vão fazer, o que vão utilizar". (P3)

Os temas selecionados para a comunicação na feira de ciências foram as seguintes: a) apresentação sobre o minicurso; b) importância das serpentes no cotidiano; c) serpentes peçonhentas e não peçonhentas e d) acidentes ofídicos. Em momento posterior, os educandos iniciaram a etapa de produção dos materiais. 


\subsection{8 - $8^{\circ}$ Encontro (12/12/2015) - Comunicando o Conhecimento sobre Serpentes no Espaço Escolar}

A organização e a preparação dos materiais que foram expostos foram realizadas na disciplina de Partes Diversificadas (PD). A professora que ministra a matéria cedeu as suas aulas para que os alunos pudessem desenvolver as atividades propostas. A feira de ciências mobilizou até mesmos os aprendizes que não participavam do minicurso, visto que estes se entrosaram com os cursistas e realizaram várias tarefas manuais como modelos, cartazes, artigos para a decoração da sala e outros.

Ao decorrer das etapas, pode-se perceber pela apresentação dos alunos e por meio da preparação dos materiais para a feira de ciências, que alguns dos procedimentos e atitudes encontrados durante as outras etapas do minicurso, também foram observados durante este último encontro.

Durante o processo de produção dos materiais, os alunos, de modo geral, desenvolveram/manifestaram atitudes em relação à ciência, principalmente no que diz respeito à motivação, os mesmos não mediram esforços para construírem os recursos, uma vez que efetuavam pesquisas, traziam materiais de casas, elaboravam resumos e marcavam encontros para ensaiar a apresentação. Também surgiram atitudes voltadas para a aprendizagem da ciência, posto que houveram indícios de colaboração e solidariedade.

O aparecimento de diversos tipos de procedimentos também foi notado nos alunos integrantes do minicurso:

a) Aquisição da informação - os aprendizes buscaram e captaram a informação em várias fontes de pesquisa para construir os cartazes e embasar o processo de comunicação. A observação também foi um procedimento desenvolvido/demonstrado, já que os mesmos extraíram várias informações dos espécimes de serpentes que estavam expostas, para identificar a questão da peçonha (Figura17b).

b) Interpretação da Informação - os educandos modelaram na argila algumas espécies de serpentes, realçando algumas características (Figura 17a).

c) Compreensão e organização conceitual da informação - nos cartazes construídos, verificou-se também a organização conceitual da informação, já que os discentes 
esquematizaram dados que auxiliam na identificação da espécie em relação a ser peçonhenta ou não.

d) Comunicação da informação - os estudantes utilizaram diversas formas de expressar os conhecimentos construídos de forma escrita, por meio de cartazes e desenhos, e também via comunicação oral.

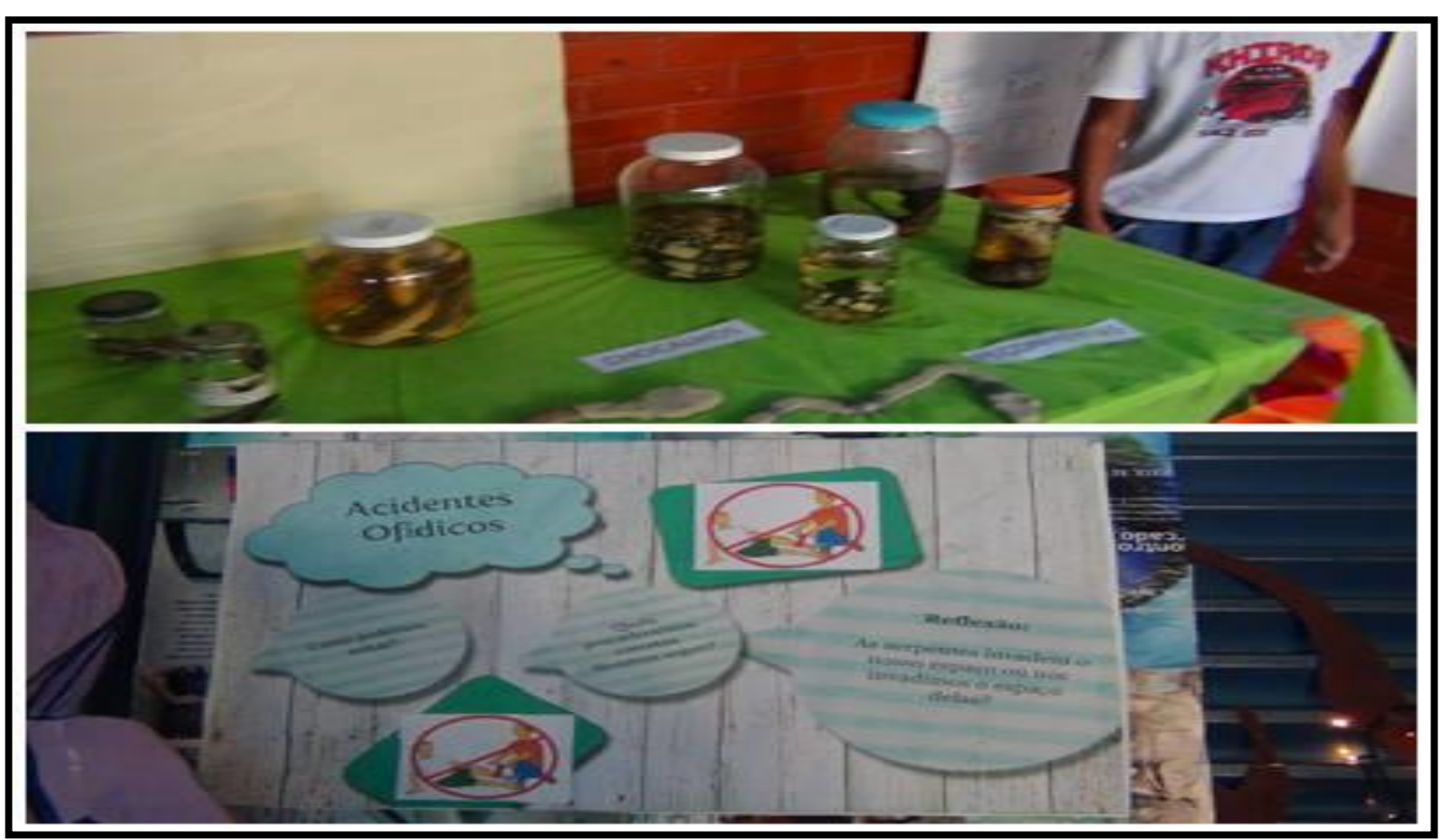

Figura 17- a) modelos construídos pelos alunos e b) cartazes confeccionados sobre acidentes ofídicos.

O processo de modelização vem aparecendo desde os primeiros encontros, e esse procedimento merece destaque, já que a ciência é construída por meio da elaboração de modelos e teorias (POZO; CRESPO, 2009). Nesse sentido, Pozo e Crespo (2009, p. 20), afirmam ainda que [...] "a ciência não é um discurso sobre o "real", mas um processo socialmente definido pela elaboração de modelos para interpretar a realidade".

No dia da montagem dos materiais, na sala de aula reservada para a execução da feira, discentes de outras séries também ajudaram na organização, colando os cartazes, cortando letras, decorando o ambiente, enquanto os participantes do minicurso estudavam e ensaiavam para a apresentação. A atividade envolveu a escola em conjunto, não foi algo restrito aos alunos do minicurso e a disciplina de Ciências Naturais, tendo em vista que a intervenção permeou vários âmbitos. 
Para dar desfecho ao minicurso, foi proposto que os educandos compartilhassem com a comunidade escolar os conhecimentos propiciados pela participação no minicurso. Os estudantes não mediram esforços para explicitar de forma dinâmica e didática as temáticas aprendidas. Os mesmos organizaram-se para receber no máximo seis convidados por apresentação.

No período do intercâmbio de informações, notou-se novamente o aparecimento dos procedimentos e das atitudes. Um dos procedimentos que foram mais evidentes nessa etapa foi referente à comunicação da informação, na modalidade oral, no qual os estudantes mostraram domínio da temática em estudo. Nesse instante, eles também iam fazendo questionamento aos visitantes, no intuito de promover uma interação, ou seja, desenvolveram formas de fazer perguntas. Procedimentos voltados para a organização conceitual também foram desenvolvidos/demonstrados, já que eles explicaram a questão da classificação entre peçonhentas e não peçonhentas, utilizando os cartazes e os espécimes de serpentes.

Atitudes como solidariedade, cooperação e gosto pelo rigor e precisão no trabalho foram gerados, considerando que os aprendizes iam complementando a fala do colega que esquecia algum detalhe, focalizando em um trabalho de maior qualidade. Essas atitudes foram desenvolvidas/demonstradas graças ao escopo da feira que possibilitava os discentes a trabalharem com grupos diferentes, compartilhando materiais e responsabilidades (ZABALA, 1998).

Desse modo, Zabala (1998, p. 107) destaca a importância de "criar uma clima em que os meninos e meninas percebam que são levados em conta; em que haja espaços onde possam atuar sentindo que o fazem segundo seus próprios critérios" valorizando as suas opiniões, confiando nas suas capacidades, conforme foi estabelecido na feira de ciências (ZABALA, 1998, p. 107).

\subsection{Quadro-Resumo: Os Principais Conteúdos Procedimentais e Atitudinais Desenvolvidos/Demonstrados nos Estudantes com a Proposta Didática}

Com as atividades aplicadas ao decorrer do minicurso sobre serpentes, juntamente com as estratégias, recursos didáticos adotados e o processo mediacional, percebeu-se que os elementos atitudinais e os procedimentais, conforme entendidos por Pozo e Crespo (2009), foram surgindo ao longo dos encontros, uns se repetiam mais, alguns eram mais simples, 
outros exigiam mais o aspecto intelectual do que o motor, estes ainda se entrelaçavam e determinados elementos davam suporte para o aparecimento de novos tipos de conteúdos.

Ao fazer uma análise mais geral, o seguinte quadro resumo (Tabelas 15) evidencia os principais conteúdos de corpus atitudinal e procedimental, que foram aparecendo ao longo dos encontros, embasados nos pressupostos de Pozo e Crespo (2009), que estão elucidados nas Tabelas 1 e 2: 
Tabela 15- Principais conteúdos procedimentais desenvolvidos/demonstrados com a intervenção realizada.

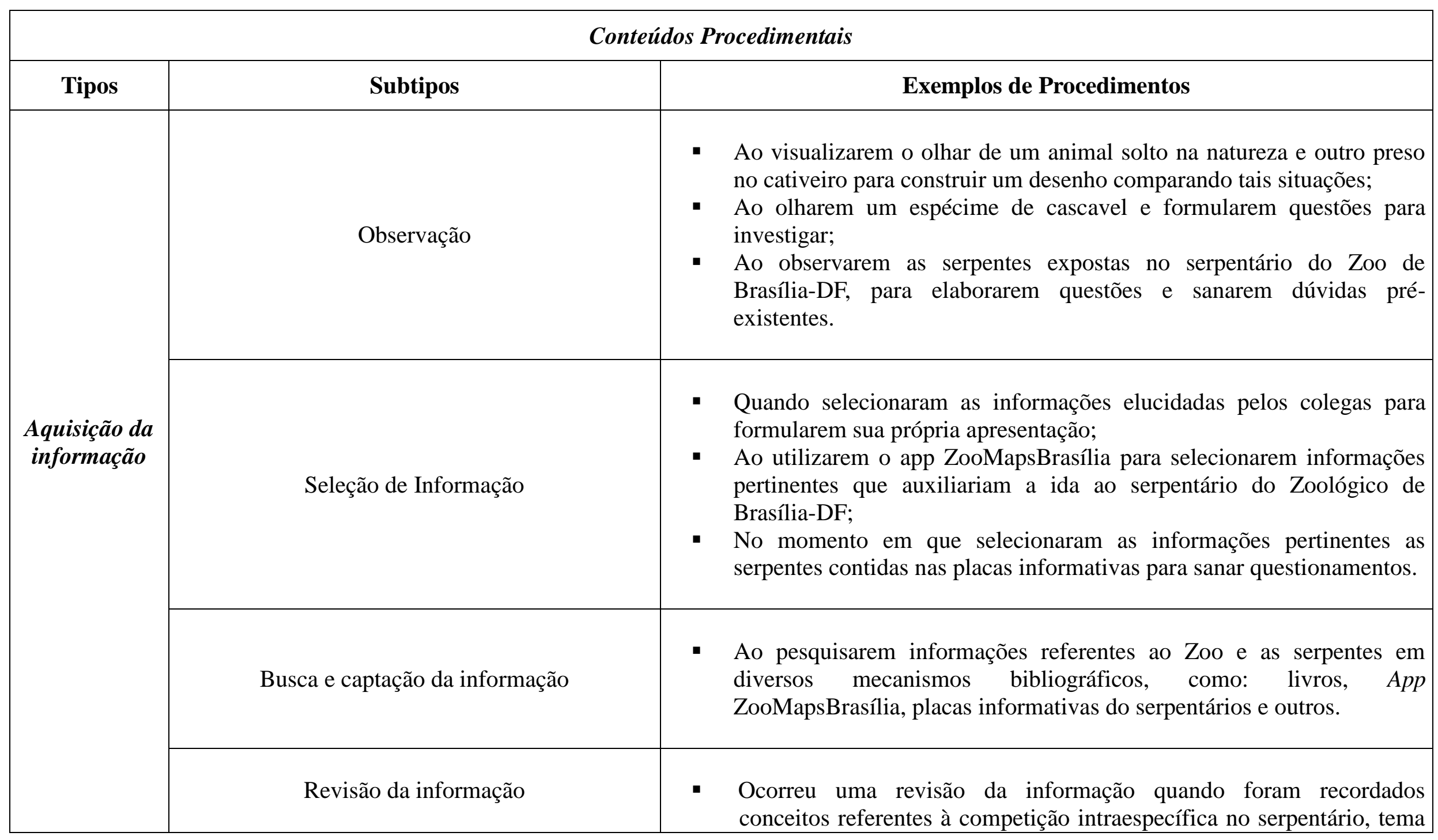




\begin{tabular}{|c|c|c|}
\hline & & que já havia sido abordado nas aulas de Ciências Naturais. \\
\hline \multirow[b]{2}{*}{$\begin{array}{l}\text { Interpretação } \\
\qquad \text { da } \\
\text { informação }\end{array}$} & Tradução da informação & $\begin{array}{l}\text { - Quando os aprendizes traduziam termos ou frases para os integrantes } \\
\text { do grupo que não haviam compreendido determinado conceito. }\end{array}$ \\
\hline & Uso de modelos para interpretar situações & $\begin{array}{l}\text { - Ao desenharem a cascavel, indicando suas características anatômicas; } \\
\text { - Quando construíram modelos para explicar a diferenciação entre } \\
\text { serpentes peçonhentas e não peçonhentas. }\end{array}$ \\
\hline \multirow{3}{*}{$\begin{array}{l}\text { Análise da } \\
\text { informação e } \\
\text { realização de } \\
\text { inferências }\end{array}$} & Análise e comparação da informação & $\begin{array}{l}\text { - Ao compararem as informações presentes em diferentes bilhetes para } \\
\text { construir um novo documento. }\end{array}$ \\
\hline & Estratégias de raciocínio & $\begin{array}{l}\text { - Quando um determinado aluno sugeriu que seu colega anotasse as suas } \\
\text { dúvidas no diário de campo e depois fizesse uma pesquisa. }\end{array}$ \\
\hline & Modos de fazer perguntas & $\begin{array}{l}\text { - Ao elaborarem perguntas sobre o tema em estudo para o grupo que } \\
\text { estava apresentando; } \\
\text { - Ao formularem questões acerca das serpentes, no Zoo-DF. }\end{array}$ \\
\hline \multirow{2}{*}{$\begin{array}{l}\text { Compreensão } \\
\text { e organização } \\
\text { conceitual da } \\
\text { informação }\end{array}$} & Compreensão do discurso & $\begin{array}{l}\text { - Quando um educando auxiliou o colega a compreender o conceito de } \\
\text { vivíparas. }\end{array}$ \\
\hline & Estabelecimento de relações conceituais & $\begin{array}{l}\text { - No momento em que correlacionaram a importância das serpentes a } \\
\text { conceitos complexos da área de ecologia; }\end{array}$ \\
\hline
\end{tabular}




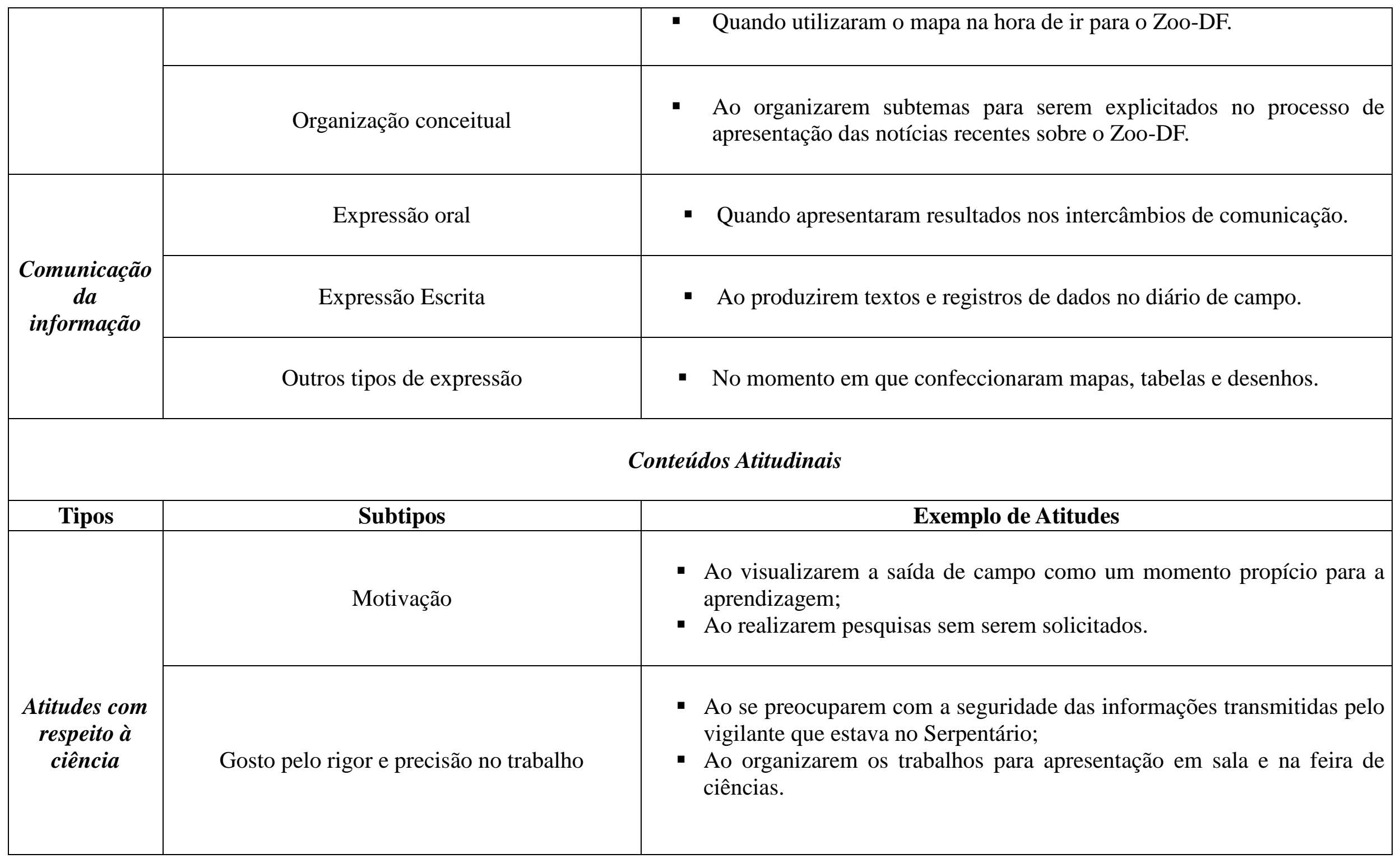




\begin{tabular}{|c|c|c|}
\hline & Respeito pelo meio ambiente & $\begin{array}{l}\text { - Ao perceberem como a interferência humana pode destruir habitats e } \\
\text { intervir no processo de extinção dos animais. }\end{array}$ \\
\hline & Atitude crítica e reflexiva & $\begin{array}{l}\text { - Ao apresentarem argumentos contrários e cabíveis à opinião da pessoa } \\
\text { entrevistada; } \\
\text { - Ao repensarem o papel das serpentes nos ecossistemas. }\end{array}$ \\
\hline & Enfoque profundo & $\begin{array}{l}\text { - Ao apresentarem significado dos anéis do guiso da serpente exposta na } \\
\text { atividade prática; } \\
\text { - Ao procurarem novas informações sobre as serpentes como o que fazer } \\
\text { quando tem uma dentro de casa. }\end{array}$ \\
\hline \multirow{3}{*}{$\begin{array}{l}\text { Atitudes com } \\
\text { respeito à } \\
\text { aprendizagem } \\
\text { da ciência }\end{array}$} & Conduta & - Quando melhoraram o comportamento ao longo dos encontros. \\
\hline & Cooperação & $\begin{array}{l}\text { Dividiram as responsabilidades para a execução da atividade referente } \\
\text { à construção dos mapas; } \\
\text { - Quando trabalharam em grupo; } \\
\text { - Quando ajudaram os colegas a estabelecerem novos conceitos. }\end{array}$ \\
\hline & Solidariedade & $\begin{array}{l}\text { - Ao compartilharem materiais pesquisados entre os componentes do } \\
\text { grupo, no momento das comunicações. }\end{array}$ \\
\hline
\end{tabular}




\begin{tabular}{|c|c|c|}
\hline $\begin{array}{l}\text { Atitudes com } \\
\text { respeito às } \\
\text { implicações } \\
\text { sociais da } \\
\text { ciência }\end{array}$ & $\begin{array}{l}\text { Discussão crítica da aplicação da ciência na } \\
\text { sociedade }\end{array}$ & $\begin{array}{l}\text { - Elaborarem questionamentos acerca de alguns prós e contras referentes } \\
\text { à manutenção de animais em cativeiros, como o Zoo. }\end{array}$ \\
\hline
\end{tabular}


Dessa forma, enaltece-se a importância do educador planejar atividades que tenham a função de desenvolver/demonstrar nos alunos os procedimentos e as atitudes, para a formação de indivíduos que tenham a capacidade de tomar decisões frente aos problemas de cunho científico, para que saibam julgar se determinada informação é verídica ou não, além de promover também o interesse e a motivação para pesquisar sobre assuntos contextualizados e ainda saibam sistematizar e compartilhar com outros essa informação (POZO; CRESPO, 2009).

Assim, as categorias propostas por Pozo e Crespo (2009) (Tabelas 1 e 2), possuem extrema relevância, tendo em vista que podem fornecer suporte para que o docente delineie atividades e também possam avaliar o aparecimento dos conteúdos de corpus atitudinais e procedimentais no âmbito das aulas de Ciências Naturais.

\section{CONSIDERAÇÕES FINAIS}

As atividades que constituem a unidade didática "Conteúdos Procedimentais $e$ Atitudinais no Ensino de Serpentes”, possuem potencial didático para mobilizar a aquisição dos mais diversos tipos de procedimentos e atitudes, conforme os aportes expostos por Pozo e Crespo (2009) e Coll et al. (1998). No entanto, ressalta-se que o recurso construído por si só não é capaz de desenvolver tais conteúdos, ele é apenas um meio norteador para que os professores utilizem estratégias investigativas para promover o desenvolvimento/demonstração dos procedimentos e das atitudes.

O sucesso da unidade didática elaborada também pode ser atribuído à forma como o material de Brito (2012) é proposto, já que este sugere que o educador insira o aluno como centro da aprendizagem, por meio de uma abordagem problematizadora, em um contexto que prima pela reflexão e o processo ao invés de um resultado final, que prioriza os conhecimentos prévios dos mesmos para a construção do conhecimento, em detrimento a um enfoque que possibilita apenas a memorização de termos e conceitos científicos. Além do mais, o processo de análise desse material, embasado nas categorias de Pozo e Crespo (2009), forneceu subsídios para implementar os conteúdos procedimentais e atitudinais como objetos de ensino da unidade didática, recebendo um tratamento didático específico.

Assim, as atividades da unidade didática, juntamente com o processo de mediação, possibilitaram que os educandos participassem de um contexto interativo, sendo estes os protagonistas do processo de ensino aprendizagem, no qual tiver ${ }^{2}$ ' "ade de 
desenvolver/demonstrar formas de fazer perguntas, debater, sistematizar ideias, explorar conhecimentos prévios, elaborar tabelas, organizar conceitualmente informações, buscar diversos dados em diferentes fontes bibliográficas, refletir, criticar, em forma cooperativa, respeitando o outro, atuando de forma conjunta.

O papel exercido pelos pibidianos colaborou para a aquisição desses elementos por parte dos discentes, posto que os mesmos atuaram como guias, orientadores e não como detentores do conhecimento, oportunizando que os alunos construíssem um aprendizado mais crítico e reflexivo, no que tange o ensino de serpentes. A participação no processo de elaboração e aplicação da unidade didática, em formato de minicurso, propiciou a reflexão dos pibidianos acerca da sua prática didático pedagógica, fornecendo subsídios para a introdução da vertente investigativa nas suas próprias aulas, além de permitir que estes percebam a importância de adotar um processo voltado para o desenvolvimento/demonstração das atitudes e dos procedimentos.

Trabalhar com a temática de serpentes, vislumbrou que os estudantes, de modo geral, compreendessem que tais animais, apesar de mobilizar o aparecimento de diversas sensações nos seres humanos, como medo, repulsa, curiosidade e outros, possuem a sua devida importância para o meio ambiente, arquitetando assim novos olhares e significados perante o assunto em estudo.

A etapa de preparação de ida para o Zoológico de Brasília-DF foi extremamente construtiva, posto que a saída perdeu o caráter de "passeio" e foi percebida como um momento propício para a aprendizagem, troca de experiências, além de permitir o contato direto dos educandos com as serpentes, fornecendo ancores para a desenvolvimento/demonstração dos procedimentos e das atitudes. Assim, salienta-se também que o espaço não formal foi visto como um instrumento motivacional para a aquisição de novos conhecimentos e reorganização das ideias prévias.

Ao longo dos encontros, percebeu-se a ocorrência de diversos tipos de procedimentos e atitudes, estes apareciam de forma aleatória, não seguiam a mesma ordem proposta nas Tabelas 1 e 2, eles se correlacionavam e alguns procedimentos levavam ao surgimento de outros. Assim, aos poucos, os educandos foram adquirindo estratégias, já que vários procedimentos foram sendo incorporadas às formas de agir e pensar dos mesmos.

As atividades grupais foram fatores marcantes que colaboraram para 0 desenvolvimento/demonstração das atitudes, os conteúdos implícitos. Essa organização favoreceu que os estudantes dividissem responsabilidades, desenvolvendo capacidades 
autônomas, colaborativas e solidárias, fortalecendo também um maior apreço pelo rigor científico.

Apesar dos conceitos, não serem motivos de análise na presente pesquisa, não deve-se desconsiderar a relevância dos mesmos para o processo de ensino aprendizagem, entendendo que para que ocorra um desenvolvimento integral dos educandos, deve ser edificada a tríade conceitos-procedimentos-atitudes, estabelecendo uma complementariedade e dependência mútua entre esses tipos de conteúdo. Enfatiza-se também que ao trabalhar priorizando essa união não se busca uma fórmula magistral para resolver todos os problemas inerentes ao ensino de ciências, mas apenas buscar ações que fomentem uma educação mais integral e global.

Assim, infere-se que o material confeccionado na presente pesquisa fornece suporte para que os docentes possam adotar a vertente investigativa no ensino de serpentes, por meio de etapa de preparação de uma ida para o serpentário do Jardim Zoológico, priorizando os conteúdos atitudinais e procedimentais, além de fomentar uma base pedagógica para a construção de novas propostas que tenham o intuito de utilizar espaços não formais, como o Zoo, para formar educandos mais ativos perante o processo de ensino aprendizagem.

Para finalizar, levando em consideração que os conteúdos procedimentais e as atitudinais já vêm sendo discutidos aqui no Brasil, desde a criação dos PCN de 1998 (BRASIL, 1998), sugere-se que novas pesquisas sejam realizadas nesse âmbito, considerando a escassa produção de material bibliográfico brasileiro existente nesse quesito, principalmente no que diz respeito à construção de materiais didáticos para o ensino de serpentes que fortificam o desenvolvimento/demonstração de tais conteúdos. 


\section{REFERÊNCIAS BIBLIOGRÁFICAS}

ARRAIS, A. A. M. O ensino de zoologia por meio de metodologias diferenciadas: o caso dos anfíbios. 2013. 35p. Trabalho de Conclusão de Curso (Licenciatura em Ciências Naturais) Faculdade UnB Planaltina, Universidade de Brasília.

ARRAIS, A. A. M.; GUIMARÃES, E. M. Uma Possibilidade para o Desenvolvimento de Conteúdos Atitudinais e Procedimentais no Ensino de Serpentes: A Análise de um Material Didático. In: X Encontro Nacional de Pesquisa em Educação em Ciências, Águas de Lindóia, SP, 2015.

AZEVEDO, M. C. P. S. A relação ciência, tecnologia e sociedade no ensino de ciências. In: CARVALHO, A. M. P. (Org.). O ensino de ciências: unindo a pesquisa e a prática. São Paulo: Pioneira Thomson Learning, 2004.

BARBATTO, S. Metodologia de Pesquisa Qualitativa. Brasília: Editora UnB, 2008.

BARBOSA, R. M. N.; JOFILI, Z. M. S. Aprendizagem cooperativa e ensino de química parceria que dá certo. Ciência e Educação, Bauru, v. 10, n. 1, p.55-61, 2004.

BRASIL. Currículo da Educação Básica. Ensino Fundamental Séries Finais. Brasília: Secretaria de Educação, 2008b.

Currículo da Educação Básica. Ensino Fundamental Séries Iniciais. Brasília: Secretaria de Educação, 2008a. 2008c.

Currículo da Educação Básica. Ensino Médio. Brasília: Secretaria de Educação,

Ministério da Educação e do Desposto. Secretaria de Educação Fundamental Parâmetros curriculares nacionais: Ciências Naturais - primeiro e segundo ciclo do ensino fundamental. Brasília: SEF, 1998b.

Ministério da Educação e do Desposto. Secretaria de Educação Fundamental. PCN+ Ensino Médio: Orientações Educacionais Complementares aos Parâmetros Curriculares Nacionais - Ciências da Natureza, Matemática e suas Tecnologias. Brasília: SEF, 1998a. 
Ministério da Educação e do Desposto. Secretaria de Educação Fundamental. PCN+

Ensino Médio: Orientações Educacionais Complementares aos Parâmetros Curriculares Nacionais - História. Brasília: SEF, 1998c.

BRITO, A. G. O Jardim Zoológico enquanto espaço não formal para promoção do desenvolvimento de etapas do raciocínio científico. 114 p. 2012. Dissertação de Mestrado (Programa de Pós Graduação em Ensino de Ciências) - Universidade de Brasília, DF.

CACHAPUZ, A.; PRAIA, J.; JORGE, M. Da educação em ciência à orientações para o ensino das ciências: um repensar epistemológico. Ciência e Educação. v. 10, n. 3, 2004, p. $363-381$.

CANDIDO, C.; FERREIRA, J.F. Desenvolvimento de material didático na forma de um jogo para trabalhar com zoologia dos invertebrados em sala de aula. Cadernos da Pedagogia. São Carlos, Ano 6 v. 6 n. 11, p. 22-33, jul-dez 2012.

Coordenação de Aperfeiçoamento de Pessoal de Nível Superior. Disponível em < www.capes.gov.br> Acesso: 13 abr. 2015.

CARVALHO, A. M. P. Ensino de ciências por investigação: condições para implementação em sala de aula. São Paulo: CENGAGE Learning, 2013.

CARVALHO, A.M.P.; VANNUCCHI, A.I.; BARROS, M.A.; GONÇALVES, M.E.; REY, R.C. Ciências no ensino fundamental: o conhecimento físico. São Paulo: Scipione, 2009.

CAVALCANTI, K. M. P. H.; SPRINGER, M. V.; BRAGA, M. Atividades experimentais em química através da metodologia de resolução de problemas. IX Congreso Internacional sobre Investigación en Didáctica de las Ciencias, 2013.

CLEMENT, L.; TERRAZZAN, E. A. Atividades Didáticas de Resolução de Problemas e o Ensino de Conteúdos Procedimentais. Revista Electrónica de Investigación en Educación en Ciencias (En línea), v. 6, p. 87-101, 2011.

COLL, C. Introdução. In: COLL, C.; POZO, J. I.; SARABIA, B.; VALLS, E. Os conteúdos na reforma: ensino e aprendizagem de conceitos, procedimentos e atitudes. Porto Alegre: Artmed, 1998.

COLL, C.; VALLS, E. A aprendizagem e o ensino dos procedimentos. In: COLL, C.; POZO, J. I.; SARABIA, B.; VALLS, E. Os conteúdos na reforma: ensino e aprendizagem de conceitos, procedimentos e atitudes. Porto Alegre: Artmed, 1998. 
DELIZOICOV, D.; ANGOTTI, J. A.; PERNAMBUCO, M. M. Ensino de Ciências: fundamentos e métodos. São Paulo: Cortez, 2009.

DUARTE, R. Entrevistas em pesquisas qualitativas. Editora UFPR. Educar, Curitiba, n. 24, p. 213-225, 2004.

ECHEVERRÍA, M. P. P.; POZO, J. I. Aprender a resolver problemas e resolver problemas para aprender. In: POZO, J. I. (Org.). A solução de problemas. Porto Alegre: Artes Médicas, 1998.

GUIMARÃES, E. M.; FALCOMER, V. A. Conteúdos atitudinais e procedimentais no ensino da metamorfose de borboletas. Enseñanza de las Ciencias , v. Extra, p. 2292-2296, 2013.

KISHIMOTO, T.M. Jogo, brinquedo, brincadeira e a educação. São Paulo: Corte, 1997.

KRASILCHIK, M. Prática de Ensino de Biologia. São Paulo: Editora da Universidade de São Paulo, 2005.

Reformas e realidade: o caso do ensino de Ciências. São Paulo em Perspectiva, v. 14 n. 1. São Paulo Jan./Mar. 2000, p. 85-93.

LAKATOS, E. M; MARCONI, M. A. Metodologia científica. 5. ed. São Paulo: Atlas, 2007.

LAVILLE, C.; DIONNE, J. A construção do saber - manual de metodologia em ciências humanas. Porto Alegre: Editora Artes Médicas Sul Ltda; Belo Horizonte: Editora UFMG, 1999.

LIMA, L. M. S. O Tao da educação: a filosofia oriental na escola ocidental. São Paulo: Agora, 2000.

LUCHESE, M. S. A herpetologia no ensino fundamental: o que os alunos pensam e aprendem. 2013. 27p. Monografia (Curso de Licenciatura Ciências Biológicas) Universidade Federal do Rio Grande do Sul, Porto Alegre.

MACHADO, D. I.; NARDI, R. Construção e validação de um sistema hipermídia para o ensino de física moderna. Revista Electrónica de Enseñanza de las Ciencias, v. 6, n. 1, 2007. 
MARANDINO, M.; SELLES, S. E.; FERREIRA, M. S. Ensino de Biologia: Histórias e Práticas em Diferentes Espaços Educativos. São Paulo: Cortez, 2009.

MARASINI, A. B. A utilização de recursos didáticos-pedagógicos no ensino de Biologia. 2010. 27p. Monografia (Curso de Licenciatura em Ciências Biológicas) Universidade Federal do Rio Grande do Sul, 2010.

MOREIRA, M. A. O professor-pesquisador como instrumento de melhoria do ensino de ciências. Em Aberto, Brasília, v.7, n.40, p. 43-54, out./dez. 1988.

OLIVEIRA, L. S; SOUZA, M. L. Articulando o ensino de zoologia com a etnozoologia: análise de uma proposta educativa com estudantes do ensino fundamental. Revista da SBEnBIO, n. 7, 2014.

PIZARRO, M. V. Histórias Em Quadrinhos E O Ensino De Ciências Nas Séries Iniciais: Estabelecendo Relações Para O Ensino De Conteúdos Curriculares Procedimentais. 188p. 2009. Dissertação de Mestrado, Universidade Estadual Paulista Júlio Mesquita Filho.

POLÔNIA, A. C.; DESSEN, M. A. Em busca de uma compreensão das relações entre família e escola. Psicologia Escolar e Educacional, 9(2), p.303-312. 2005.

POZO, J. I.; CRESPO, M. A. G. A aprendizagem e o Ensino de Ciências: do conhecimento cotidiano ao conhecimento científico. Porto Alegre: Artmed, 2009.

POZO, J. I.; POSTIGO, Y. La solución de problemas como contenido procedimental de la educación obligatoria. In: POZO, J. I; PEREZ, M. D. P.; DOMINGUEZ, J.; GOMEZ, M. A.; POSTIGO, Y. Lá solución de problemas. Editorial Santillana: Madrid, 1994.

POZO, J.I., MONEREO, C. y CASTELLÓ, M. El uso estratégico del conocimiento. In: COLL. C., PALACIOS, J. y A. MARCHESI (coord.). Desarrollo psicológico y educación, 2. Psicología de la educación escolar. Madrid: Alianza, 2001.

POZO, J. I. A sociedade da aprendizagem e o desafio de converter informação em conhecimento. Revista Pátio, v. 8, n. 31, 2004.

RODEN, H.; WARD, H. As habilidades que os alunos devem ter para aprender ciência: habilidades processuais. In: WARD, H.; RODEN, J.; HEWLETT, C.; FOREMAN, J. Ensino de Ciências. Porto Alegre: Artmed, 2010. 
RODEN, H.; WARD, H. O que é ciência. In: WARD, H.; RODEN, J.; HEWLETT, C.; FOREMAN, J. Ensino de Ciências. Porto Alegre: Artmed, 2010.

ROMANO, S. M. M. A formação de professores e a importância do mapa na compreensão da espacialidade por meio da construção de conceitos cartográficos. Bol. geogr., Maringá, v. 29, n. 2, 2011, p. 5-15.

SANDRIN, M. F. N.; PUORTO, G.; NARDI, R. Serpentes e acidentes ofídicos: um estudo sobre erros conceituais em livros didáticos. Investigações em Ensino de Ciências, Porto Alegre, v. 10, n. 3, p. 281- 298, 2005.

SANTOS, S. C. S.; FACHÍN-TERÁN, A. Condições de ensino em zoologia no nível fundamental: o caso das escolas municipais de Manaus-AM. Revista ARETE, v. 6, p.01-18, 2013.

SARABIA, B. A aprendizagem e o ensino das atitudes. In: COLL, C.; POZO, J. I.; SARABIA, B.; VALLS, E. Os conteúdos na reforma: ensino e aprendizagem de conceitos, procedimentos e atitudes. Porto Alegre: Artmed, 1998.

SILVA D.F.; MATHEUS, S. M. M.; NISHIDA, S. M.; DINIZ, R. E. S. Comparando encéfalos: material didático para o ensino de Biologia. ArqMudi. v. 2, 2007.

SOUTO, D. R. Veneno do Saber: Análise de um Material Didático para o Desenvolvimento do Pensamento Científico no Ensino de Serpentes. 2013. 24p. 2013. 35p. Trabalho de Conclusão de Curso (Licenciatura em Ciências Naturais) - Faculdade UnB Planaltina, Universidade de Brasília.

WARD, H. Investigação Científica. In: WARD, H.; RODEN, J.; HEWLETT, C.; FOREMAN, J. Ensino de Ciências. Porto Alegre: Artmed, 2010.

ZABALA, A.; ARNAU, L. Como aprender e ensinar competências. Porto Alegre: Artmed, 2010. 197 p.

ZABALA, A. A prática educativa: como ensinar. Porto Alegre: Editora Artes Médicas Sul Ltda., 1998. 


\section{APÊNDICES}

\section{Apêndice A - Termo de Consentimento Livre e Esclarecido}

Você está sendo convidado (a) para participar da pesquisa intitulada "A construção de uma unidade didática a partir do veneno do saber: inserindo os conteúdos procedimentais e atitudinais no ensino de serpentes". A proposta desse trabalho é avaliar a contribuição de uma unidade didática baseada no material didático: "O Veneno do Saber - Construindo Conhecimento no Serpentário do Jardim Zoológico de Brasília" para o desenvolvimento/demonstração dos conteúdos procedimentais e atitudinais na área de serpentes. Para tanto, será utilizada a metodologia qualitativa, que se concretiza no ciclo: levantamento de conhecimento prévio, planejamento, intervenção, descrição e avaliação. Para a coleta de dados, serão realizadas observações e questionários/entrevistas com os alunos do $6^{\circ}$ ano do Ensino Fundamental II. Para a intervenção, serão utilizados diversos recursos didáticos, inclusive, o Jardim Zoológico de Brasília. O uso posterior da pesquisa consistirá na realização na dissertação de mestrado da pesquisadora. Portanto, o sigilo é garantido bem como o direito de o participante e seus responsáveis interromperem sua participação na pesquisa a qualquer momento. Cabe ressaltar que, a participação nessa pesquisa deve ser voluntária. A presente pesquisa será realizada por Antonia Adriana Mota Arrais, estudante da Universidade de Brasília. Caso seja necessário o contato com a mesma deverá ser efetuado pelo seguinte telefone em horário comercial: 91200432. A orientadora dessa pesquisa é a Professora Doutora Eliane Mendes Guimarães e o coorientor é o Professor Doutor Delano Moody Simões Soares. Após ser esclarecido (a) sobre as informações do projeto, no caso de aceitar fazer parte do estudo, assine o consentimento de participação do aluno, que está em duas vias. Uma delas é sua e a outra é da pesquisadora responsável. Em caso de recusa você não será penalizado (a) de forma alguma.

\section{CONSENTIMENTO DO/A PARTICIPANTE OU RESPONSÁVEL}

$\mathrm{Eu}$ DECLARO que

fui esclarecida/o quanto aos objetivos e procedimentos do estudo pela pesquisadora e a orientadora, participação neste projeto de pesquisa, a realização das gravações (se necessárias) das entrevistas para fins de estudo, publicação em revistas científicas e/ou formação de professores. 
Apêndice B - Proposição didática: $O$ Ensino de Serpentes: Inserindo Conteúdos Atitudinais e Procedimentais 


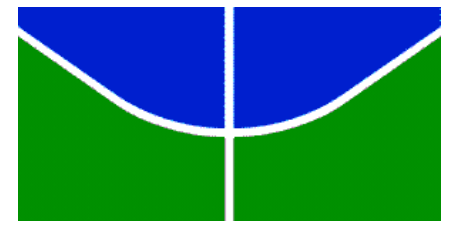

UNIVERSIDADE DE BRASÍLIA - UnB Instituto de Ciências Biológicas Instituto de Física Instituto de Química Faculdade UnB Planaltina Programa de Pós-Graduação em Ensino de Ciências Mestrado Profissional em Ensino de Ciências

\section{O Ensino de Serpentes: Inserindo Conteúdos Atitudinais e Procedimentais}

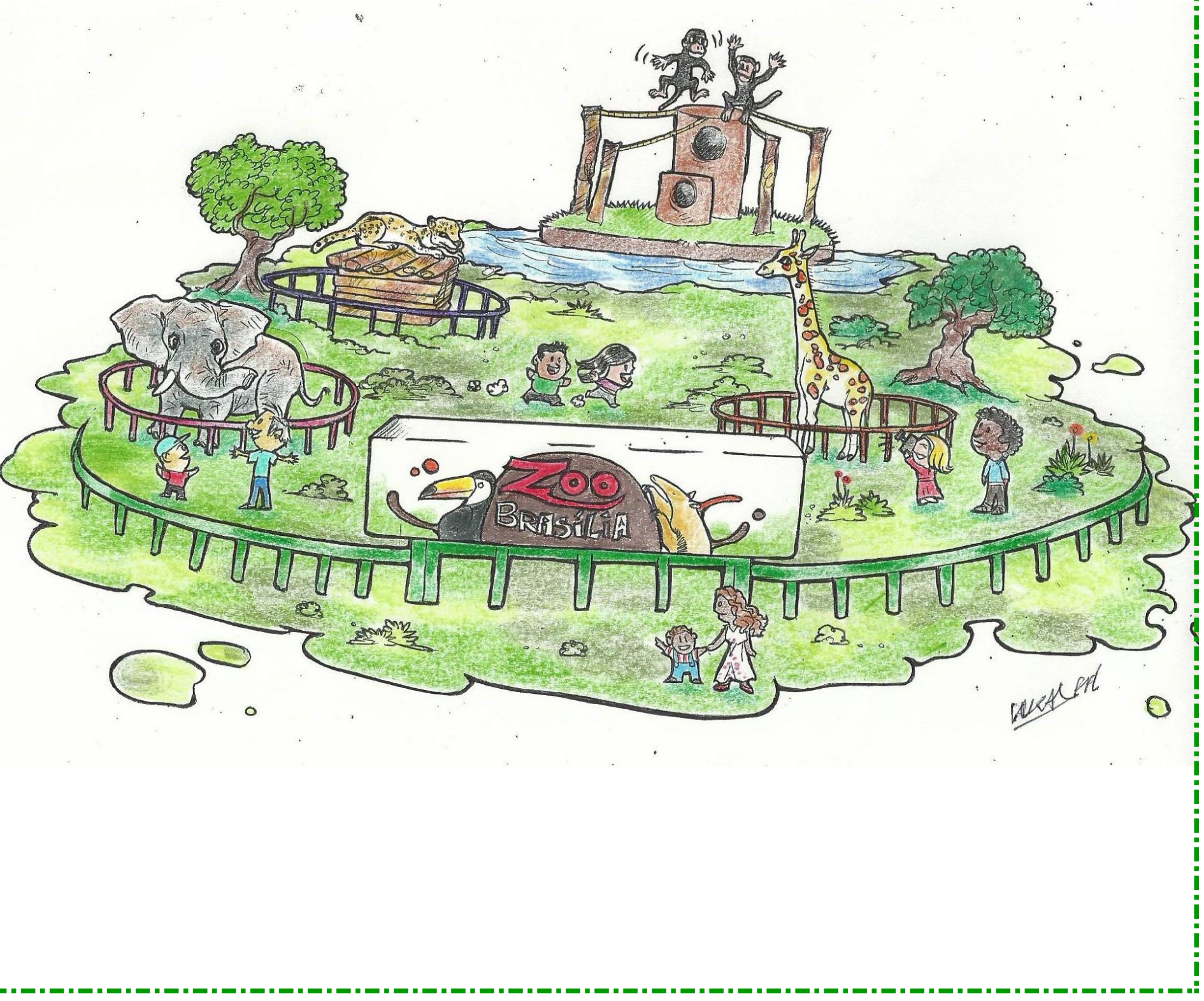




\begin{abstract}
Autores:
Antonia Adriana Mota Arrais

Eliane Mendes Guimarães

Delano Moody Simões da Silva
\end{abstract}

\title{
Ilustração:
}

Lucas Freitas Pereira Carneiro

\section{Colaboradores:}

Adailton Roger Pires Fernandes

Ariela Batista de Souto Lima

Edelvan Correia Araújo

Gaby Florença de Camargo

Lucas Freitas Pereira Carneiro

Margarete Mendes Lisboa 


\section{SUMÁRIO}

Investigazoo: problematizando com os seus estudantes sobre o zoológico/serpentário de

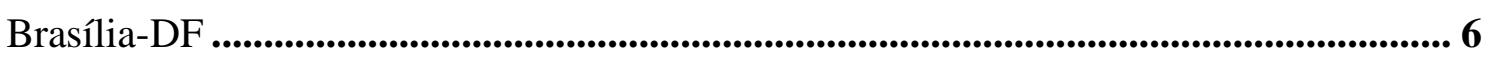

Explorando um pouco da história do jardim zoológico de Brasília-DF ............................. 9

Buscazoo: avaliando a situação atual do Zoo de Brasília - DF .......................................... 12

Appzoo: conhecendo o Zoo de Brasília-DF ...................................................................... 13

Atividade prática: conhecendo as cascáveis ................................................................. 17

Agendazoo: marcando a visita ao Zoo -DF ................................................................ 19

Localização: ida ao Zoo de Brasília - DF ...................................................................................... 21

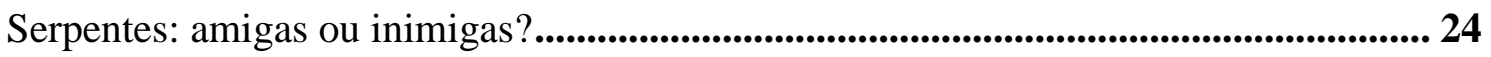

Comunicando o conhecimento no espaço escolar ................................................................... 28

Glossário para o(a) professor(a) ....................................................................................... 30

Referências bibliográficas .......................................................................................... 31 


\section{APRESENTAÇÃO}

Caro (a) Professor (a),

O presente material reúne uma gama de atividades no âmbito investigativo que têm o propósito de nortear a prática docente para um ensino de serpentes mais reflexivo, crítico e contextualizado, enaltecendo o papel do aluno como o agente ativo e responsável pelo seu processo de ensino-aprendizagem. Ao trabalhar com problemas, o educador transfere a tarefa de raciocinar, refletir e pensar para o discente e assume a função de orientar e encaminhar o mesmo na edificação de novos conhecimentos (CARVALHO, 2013).

A intenção é disponibilizar a você, professor (a), um material que permita a reflexão sobre a sua prática didático-pedagógica, fornecendo subsídios para que você busque significativas melhorias no ensino de Ciências, encaminhando-se assim, para uma possível ruptura inicial do modelo tradicional de ensino, método este que prima pela memorização de fatos e conceitos, compartimentação do conhecimento científico e o pensamento acrítico e estanque, e procurando inserir o educando em um contexto de aprendizagem problematizadora.

O conjunto de atividades que compõe esse recurso foi construído a partir análise das possibilidades dos conteúdos procedimentais e atitudinais que podem ser desenvolvidos/demonstrados com a aplicação do material didático preexistente: " $\mathrm{O}$ Veneno do Saber: Construindo Conhecimentos no Serpentário do Zoológico de BrasíliaDF" (BRITO, 2012). Os conteúdos procedimentais dizem respeito ao saber fazer e aplicar. Compreendem ações orientadas para a consecução de metas ou tarefas. São exemplos de conteúdos procedimentais: observação, seleção de informações em diferentes mecanismos de pesquisa, construção de gráficos e tabelas, comunicação de ideias e outros. Já os conteúdos atitudinais são referentes às normas, atitudes e valores. Tais elementos buscam o desenvolvimento da colaboração, cooperação, motivação, espírito crítico e reflexivo, discussão acerca das implicações sociais da ciência e outros (POZO; CRESPO, 2009). 
Algumas atividades desse material foram adaptadas do recurso de Brito (2012) e novas também foram elaboradas. Tais tarefas evidenciam uma etapa de preparação de ida ao Zoológico de Brasília-DF, especificamente ao serpentário. Dessa forma, o Zoo é apresentado como um espaço potencializador da aprendizagem, e não apenas como um meio propício para o lazer e a diversão. Além do mais, as saídas de campo para os zoológicos, quando bem planejadas e sistematizadas, são importantes instrumentos para ganho de sociabilidade, capacidade de trabalho em equipe, valores e atitudes favoráveis à conservação ambiental e habilidades de liderança (MARANDINO, SELLES; FERREIRA, 2009).

As atividades descritas contam com uma série de recursos didáticos diferenciados, como jogos, notícias, atividades práticas, saídas de campo, história em quadrinhos, aplicativos e feira de ciências, para que você possa tornar a sua aula ou encontro mais dinâmico e motivador, atendendo as necessidades específicas e os gostos de cada educando, vislumbrando o desenvolvimento/demonstração das atitudes e dos procedimentos.

O material didático apresentado, por si só, não é capaz de transformar a realidade do ensino de serpentes, mas fornece ideias para você que busque novos significados e cores para as suas aulas de zoologia, propendendo à formação de educandos autônomos, críticos, questionadores e competentes.

A você professor (a), fique a vontade para inserir novas atividades, alterar a disposição das mesmas, substituir os recursos didáticos apresentados, almejar diferentes objetivos e assim por diante. Nesse sentido, espera-se que essas atividades possuam grandes contribuições para você, uma vez que ao ser aplicado em um minicurso refletiu valiosos conhecimentos para os discentes e também para os mediadores. 


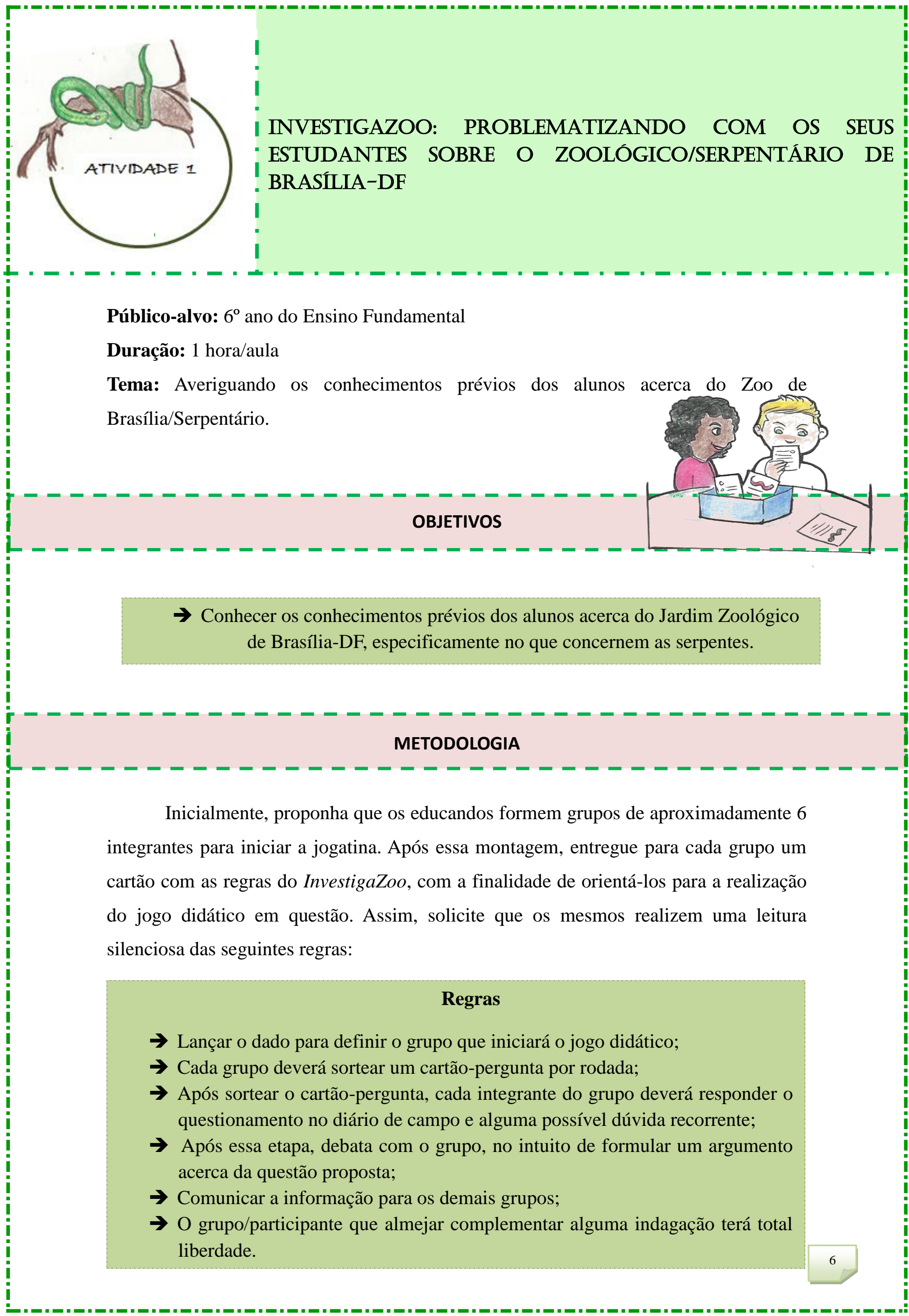



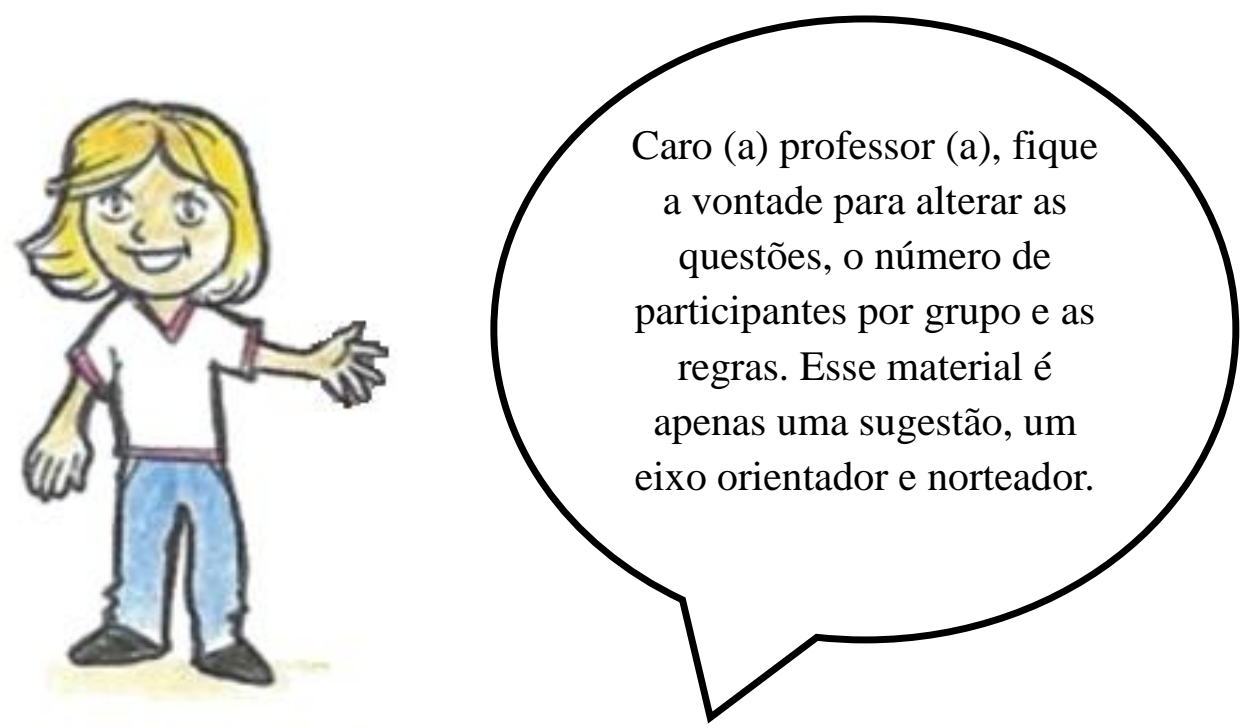

Ao término da leitura, inicie a aplicação do jogo didático "InvestigaZoo".

\section{RECURSOS DIDÁTICOS E MATERIAIS}

\section{Jogo Didático: "INVESTIGAZOO"}

O jogo didático intitulado de "InvestigaZoo" é composto por 10 cartõesperguntas. Para a confecção desse material, utilize os seguintes materiais: papel contact, papel couchê, impressora colorida, caixas e dado. As questões apresentaram um caráter investigativo, onde os educandos poderão elucidar suas opiniões, dúvidas e questionamentos.
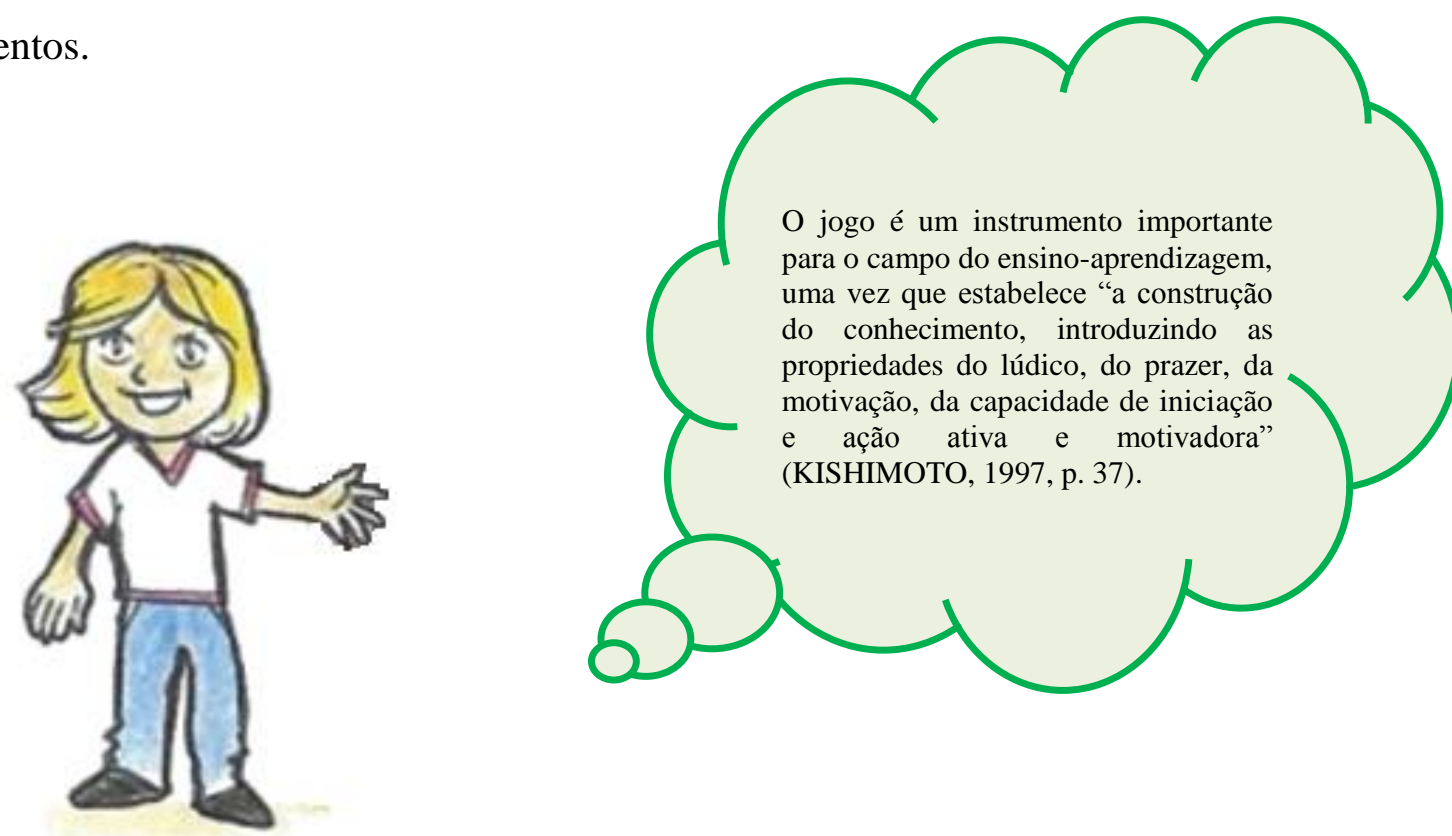


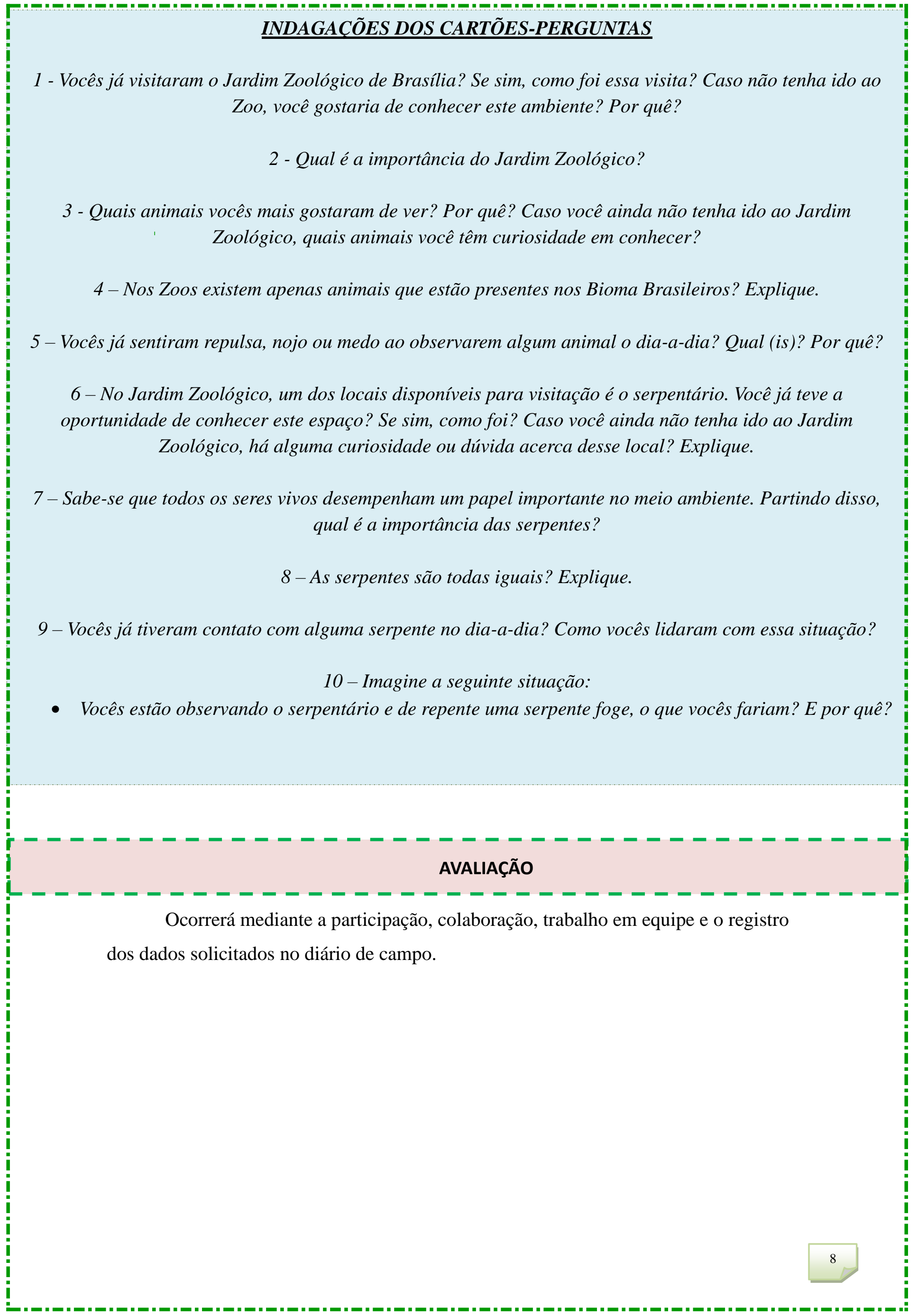




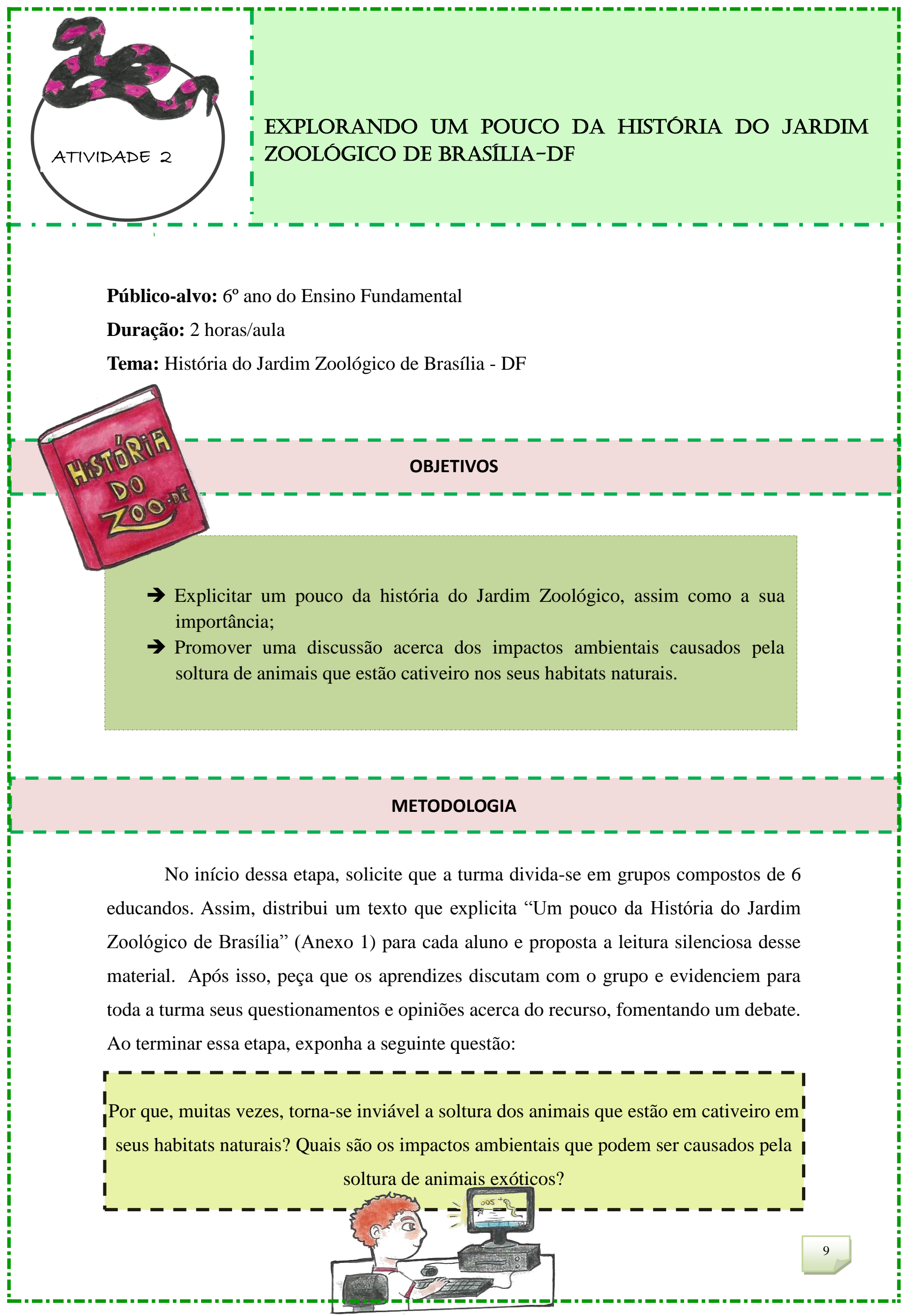


Logo, sugira que os aprendizes expressem e anotem no diário de campo as suas opiniões acerca da questão. Para auxiliá-los, encaminhe-os ao laboratório de informática no intuito de pesquisar e selecionar informações acerca da questão investigativa proposta. Em sala de aula, os educandos proponha que os educandos comuniquem as informações obtidas. E para finalizar essa etapa, recomende que cada discente leve para a próxima aula, notícias recentes sobre o Zoo de Brasília-DF, compreendendo o período entre 2014 e 2015.

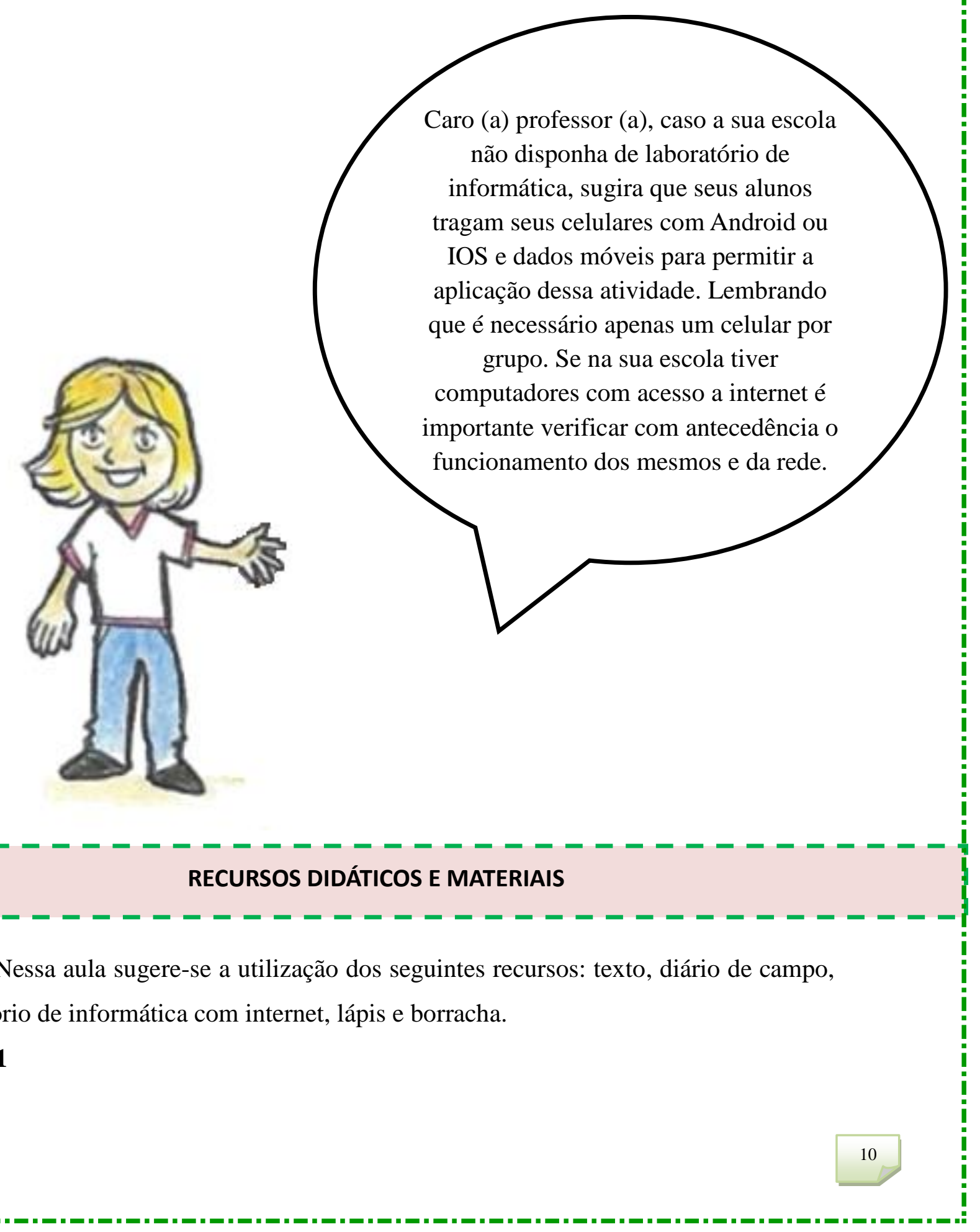




\section{Texto: UM POUCO DA HISTÓRIA DO ZOOLÓGICO DE BRASÍLIA - DF}

Nosso Zoo foi uma das primeiras instituições ambientalistas criada no Distrito Federal, sendo inaugurado em seis de dezembro de 1957, data anterior a inauguração da Capital Federal. Os Candangos que aqui chegaram para construir a cidade no fim dos anos 50 utilizaram amplamente do Jardim Zoológico como fonte prazerosa de entretenimento e de lazer. Alguns se perguntam de onde os animais são retirados! Do ambiente natural? Não. Hoje em dia alguns esses animais são provenientes de doações ou permutas entre os Zoos, que já conseguem reproduzir de modo eficiente parte das espécies. De maneira geral, não são mais retirados animais do ambiente natural para exposição, mas muitos animais resgatados de tráficos ilegais ou doentes encontram no Zoológico abrigo, cuidados e aumento na expectativa de vida.

\section{Qual objetivo de manter animais em cativeiro?}

A manutenção de animais em cativeiro pode ser importante, pois auxilia no conhecimento e aproxima as características desses animais ao cidadão que, por vezes, nunca teria contato com ele. Fonte também de pesquisa científica e ações que possibilitam a reprodução de espécies ameaçadas de extinção, levando conscientização para a população da importância dessas espécies para o meio ambiente. Muitos animais que fazem parte do plantel do Jardim Zoológico se encontravam de forma irregular e/ou sofriam maus tratos em cativeiros (residências, chácaras, zoológicos particulares, circos, etc.) ou foram apreendidos pelos órgãos ambientais competentes, sendo muitos resgatados do tráfico de 101 animais, o que torna, na maioria das vezes, inviável a soltura dos mesmos nos seus ambientes naturais.

Alberto Gomes de Brito

\section{AVALIAÇÃO}

Ocorrerá mediante o envolvimento, colaboração, trabalho em equipe, seleção de informações durante a pesquisa solicitada e registro dos dados no caderno de campo. 


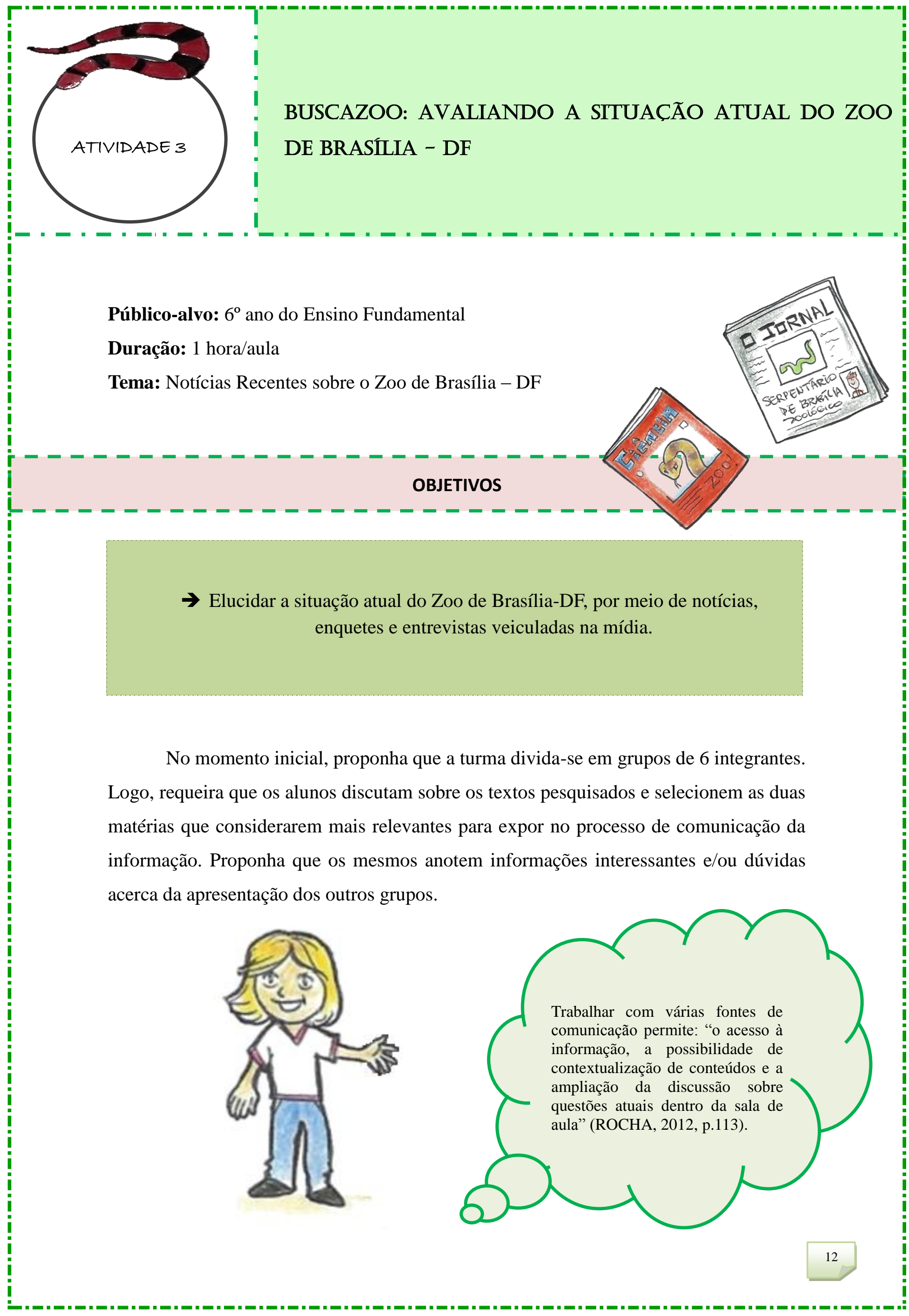




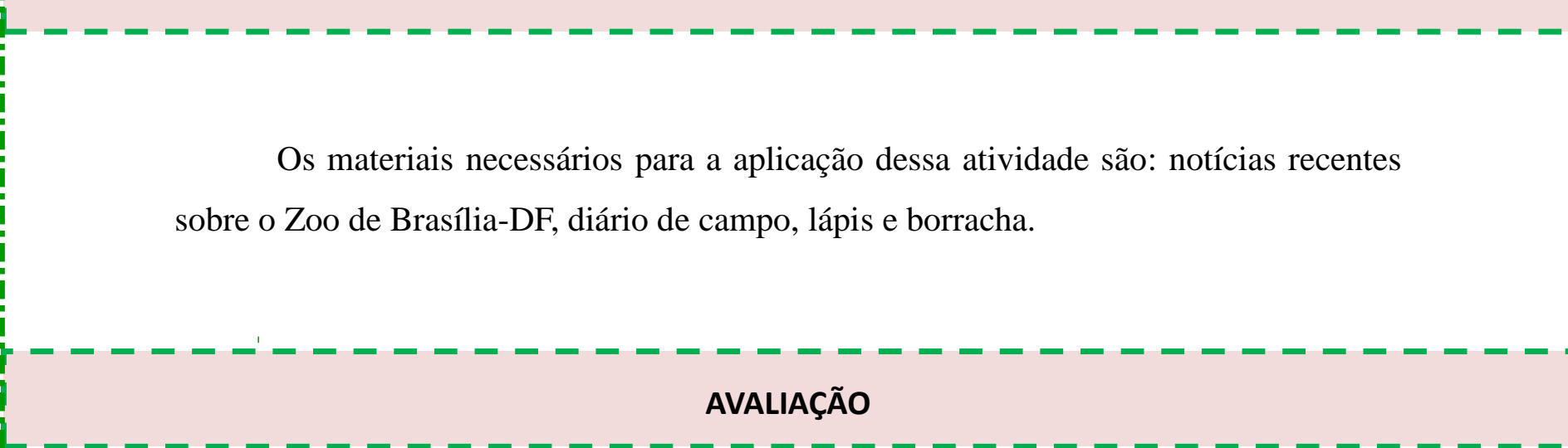

\section{AVALIAÇÃO}

O processo avaliativo ocorrerá mediante o processo de pesquisa, envolvimento na discussão propiciada pela leitura das notícias e registro dos dados no diário de campo.

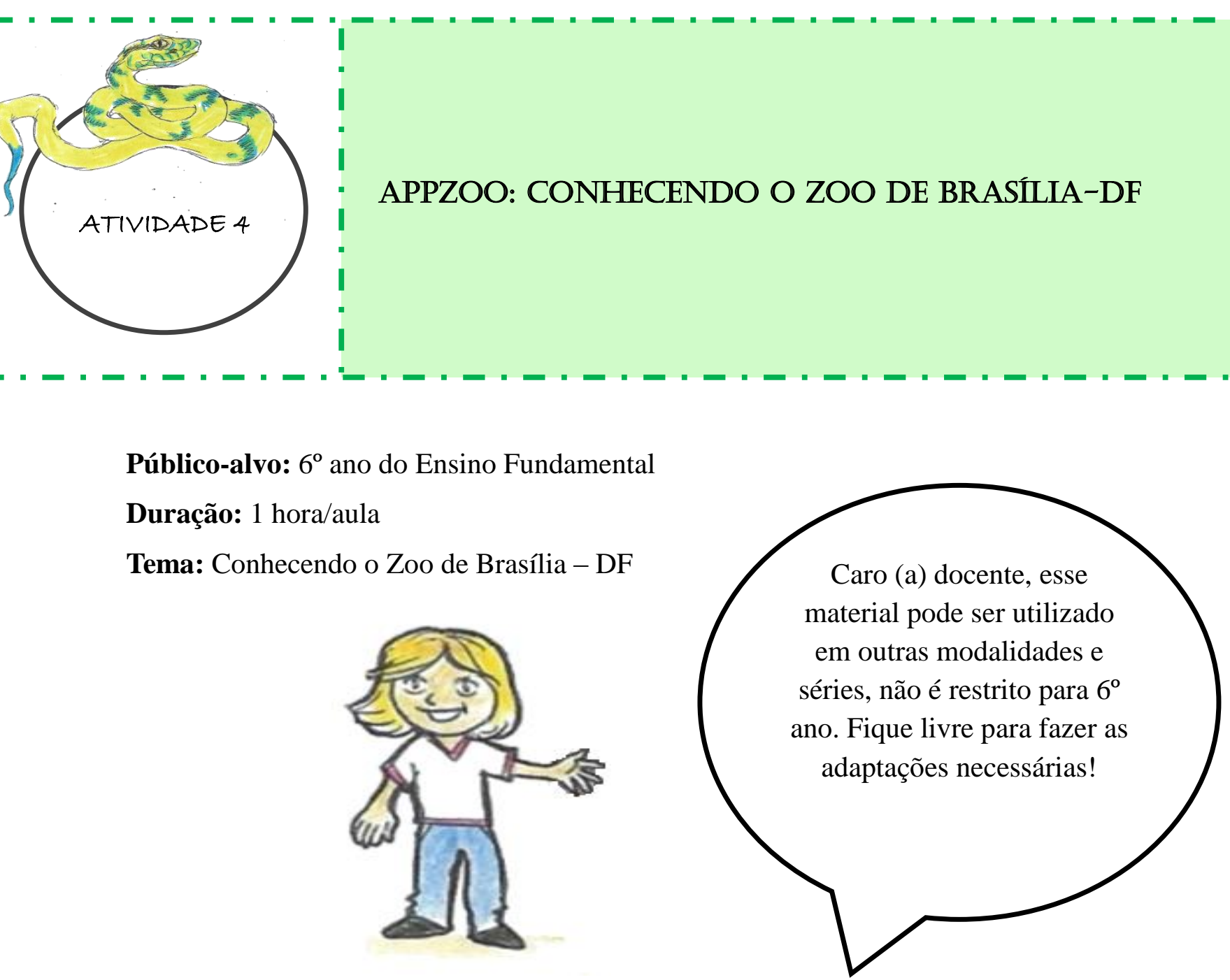




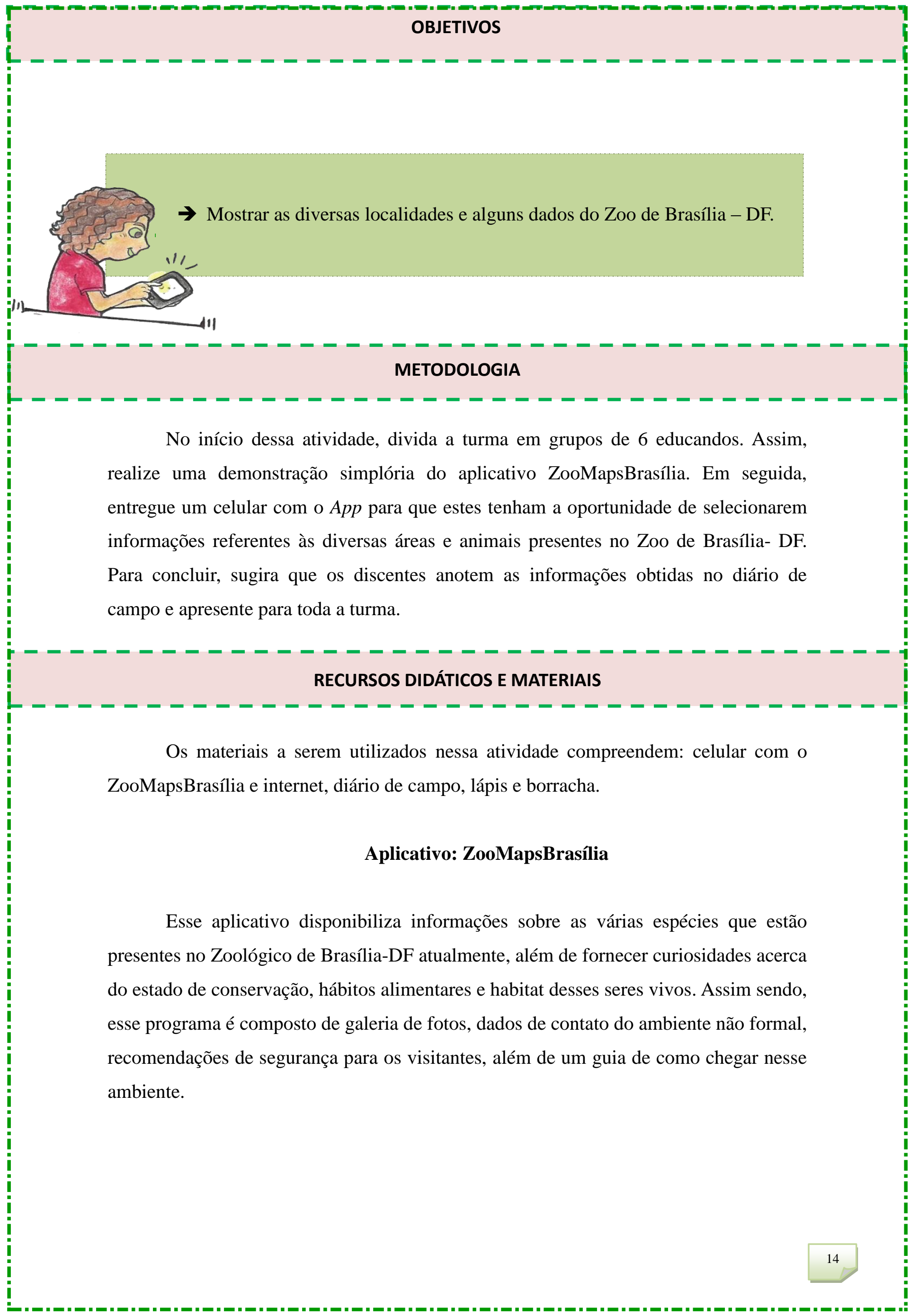




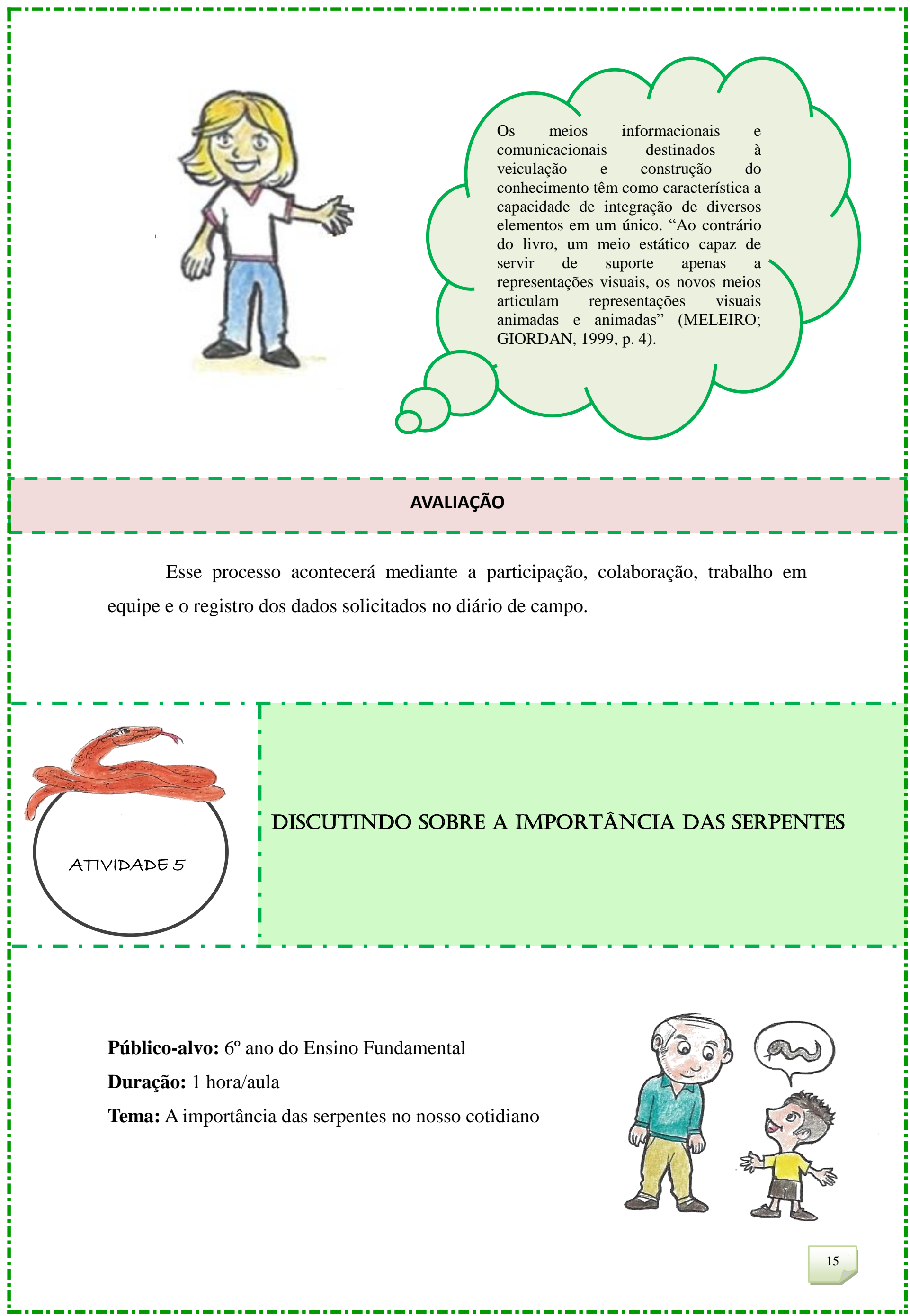




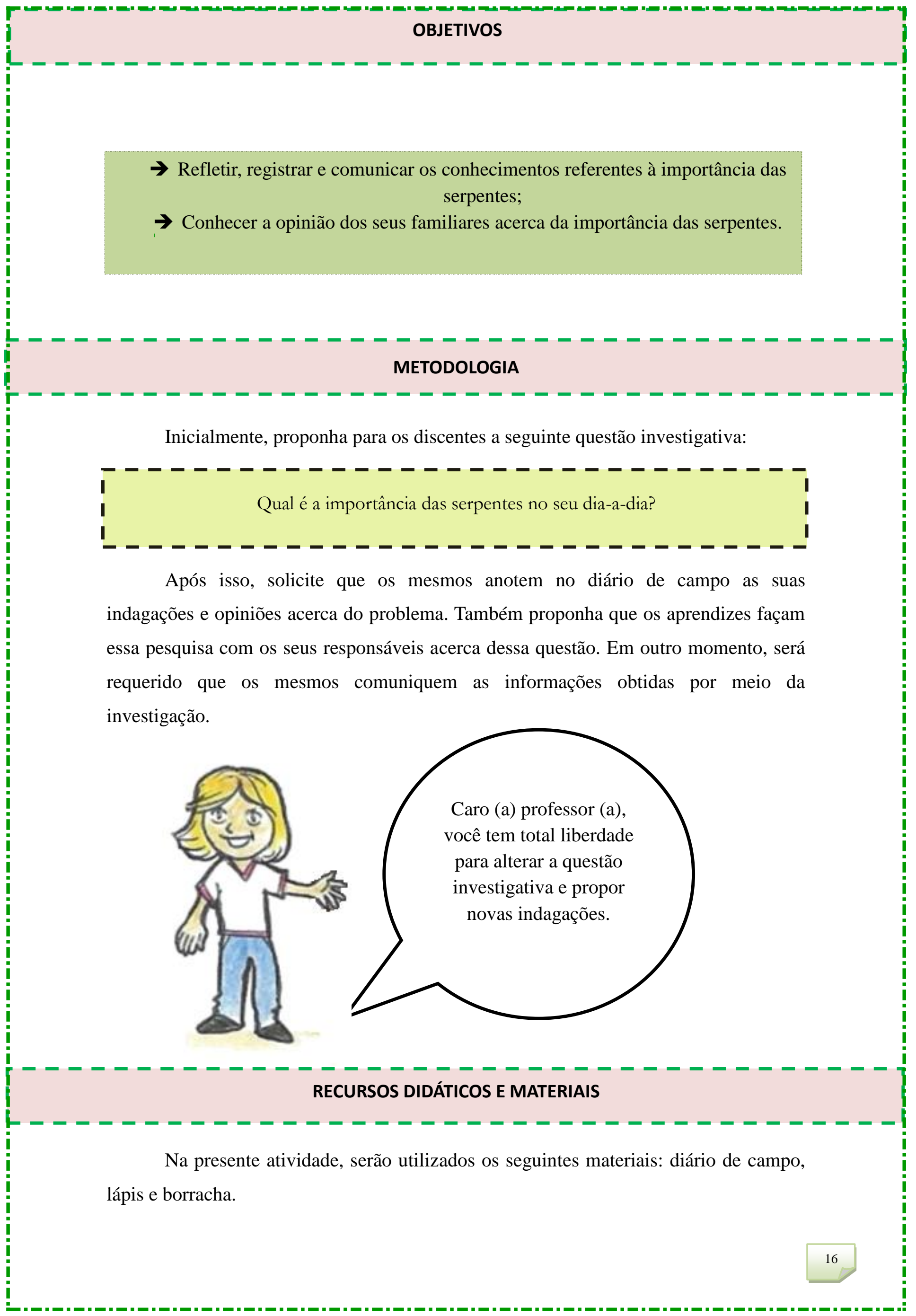


Ocorrerá mediante o registro dos dados solicitados no caderno de campo e a pesquisa requerida para casa.

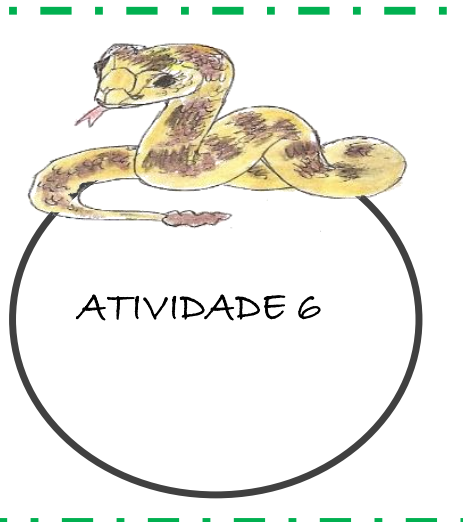

\section{ATIVIDADE PRÁTICA: CONHECENDO AS CASCÁVEIS}

Público-alvo: $6^{\circ}$ ano do Ensino Fundamental

Duração: 2 hora/aula

Tema: Conhecendo as cascáveis

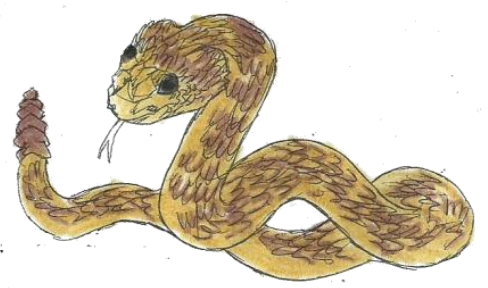

\section{OBJETIVOS}

$\rightarrow$ Observar a estrutura anatômica de um exemplar de cascavel;

Formular hipóteses acerca da formação dos anéis da cauda das cascáveis.

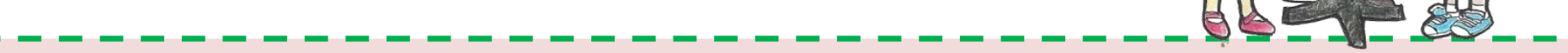

\section{METODOLOGIA}




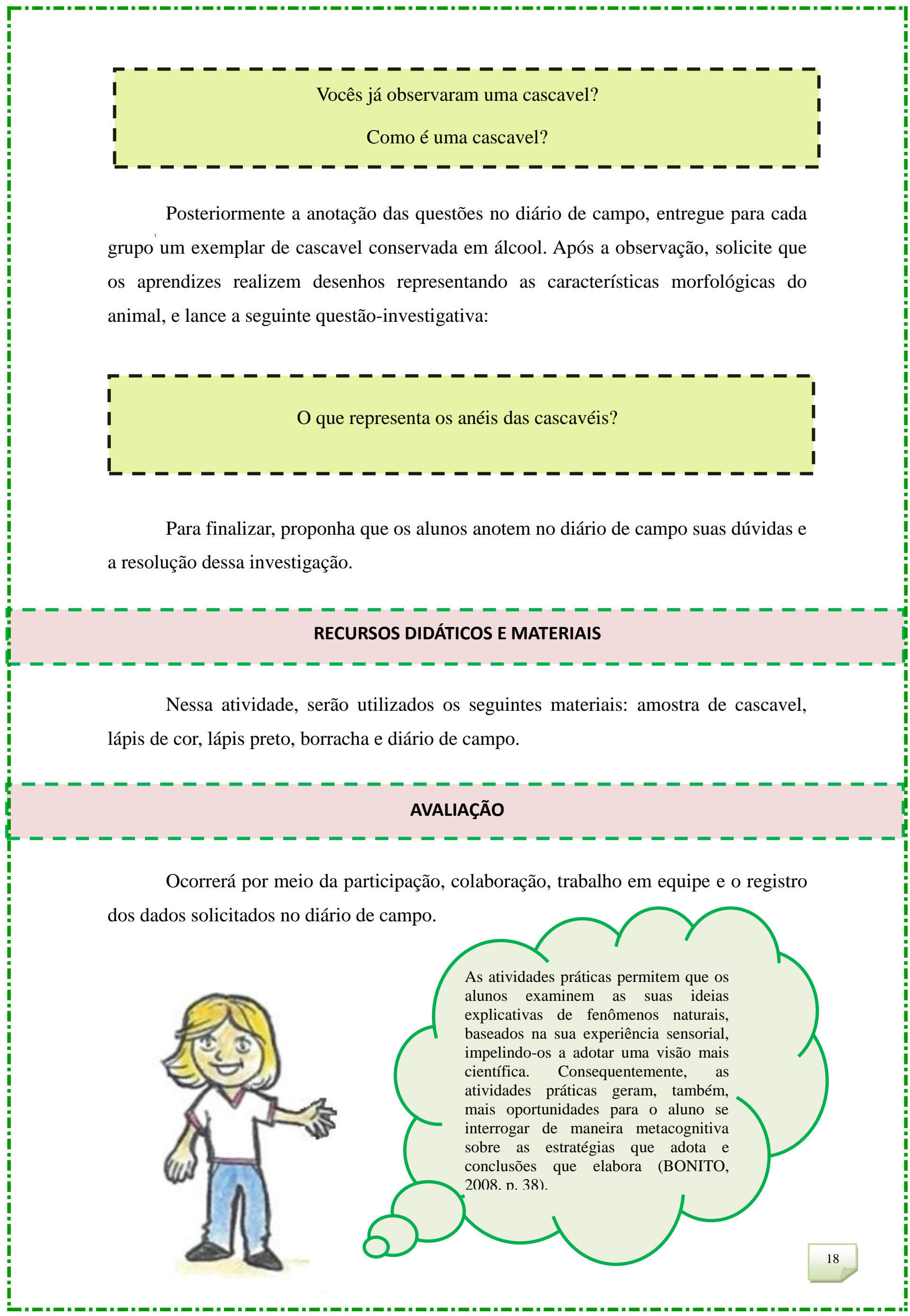




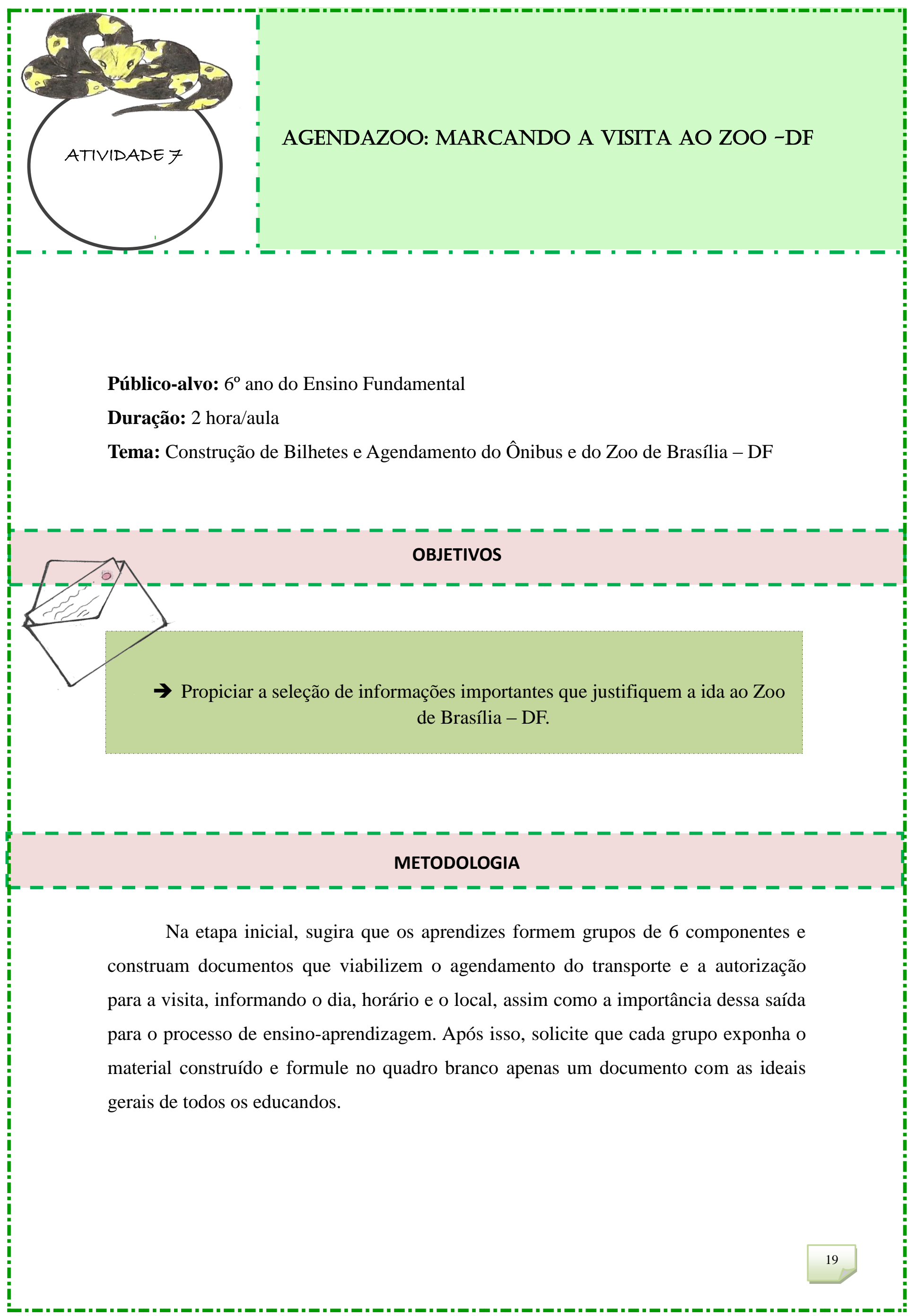




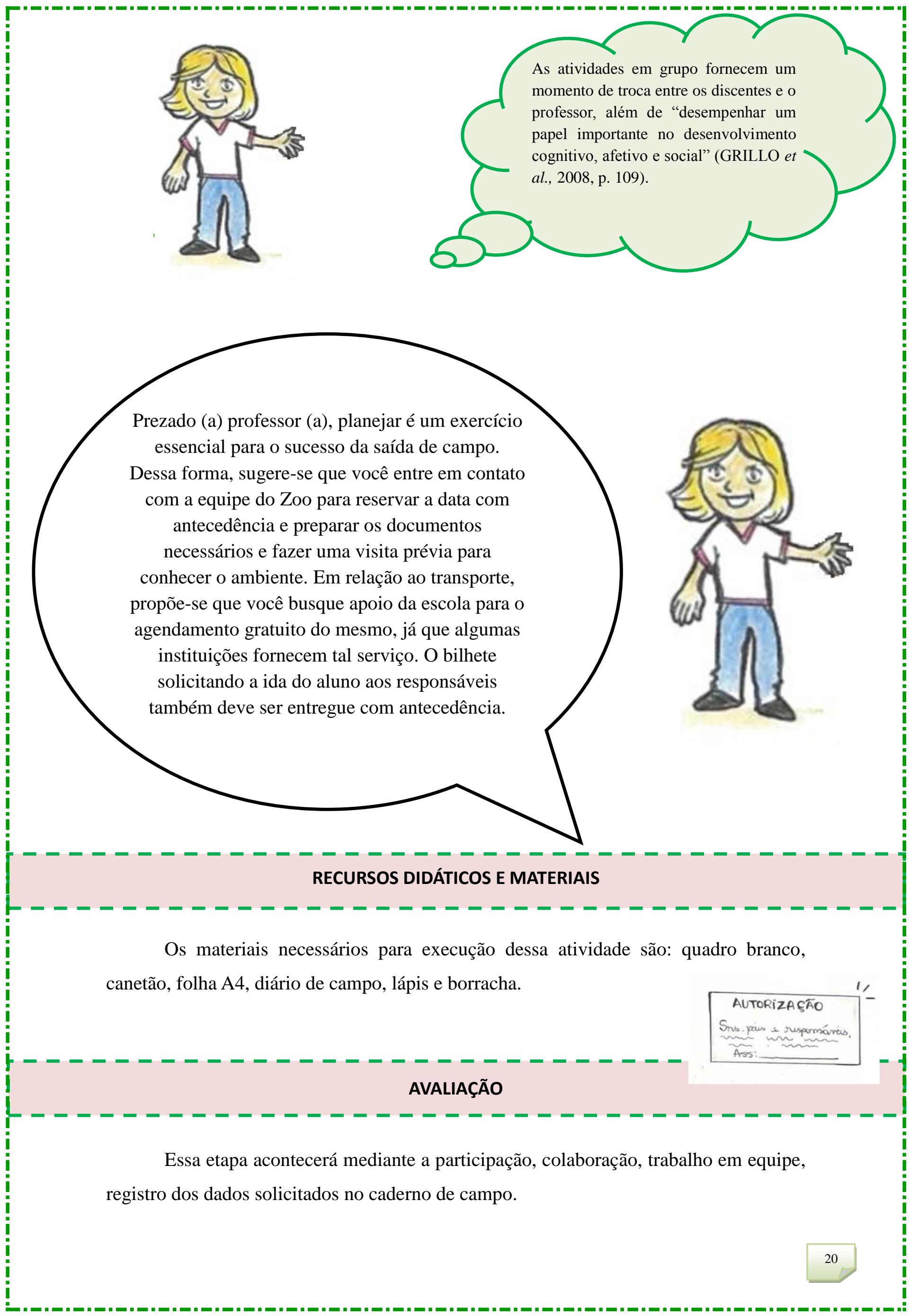




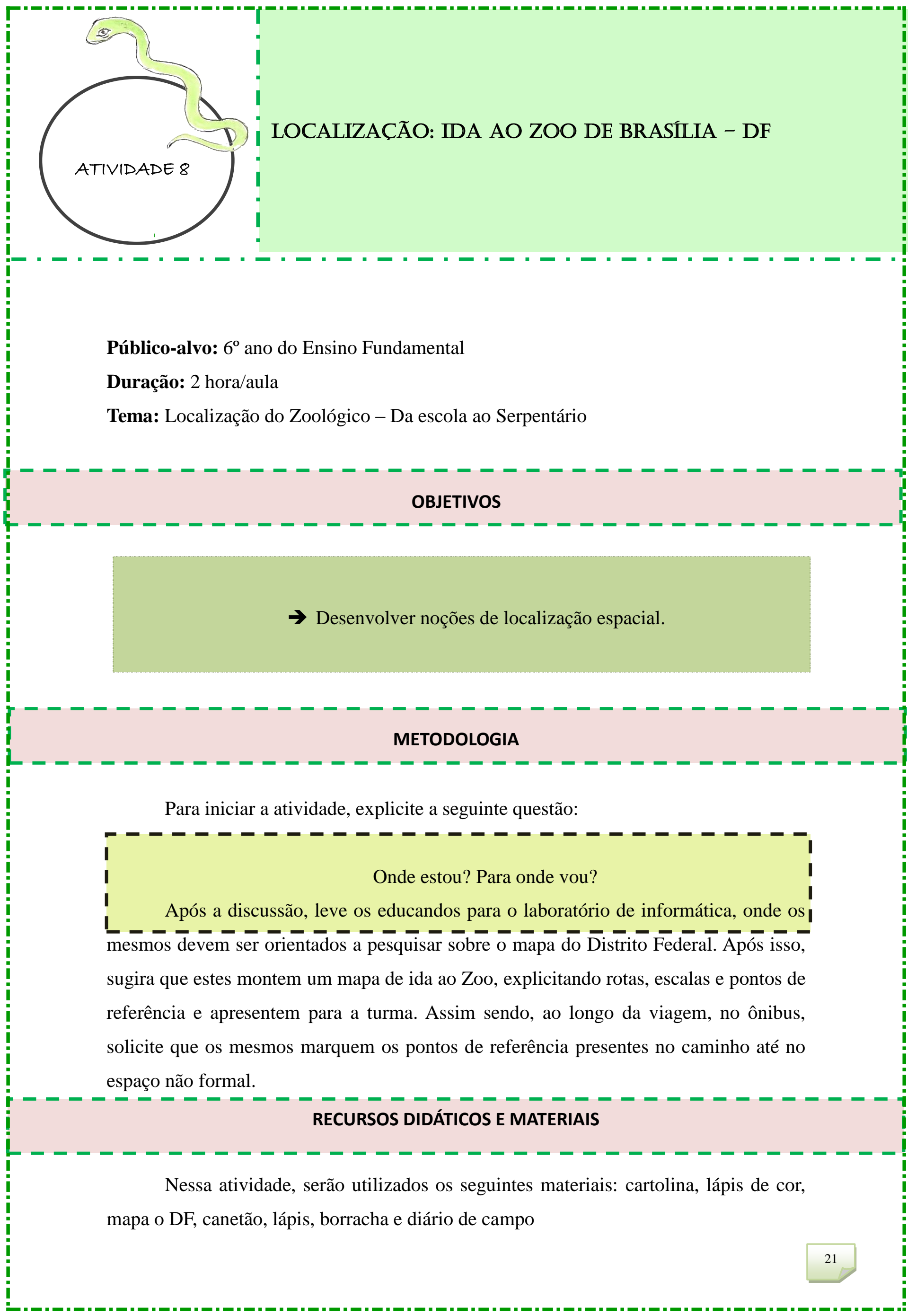




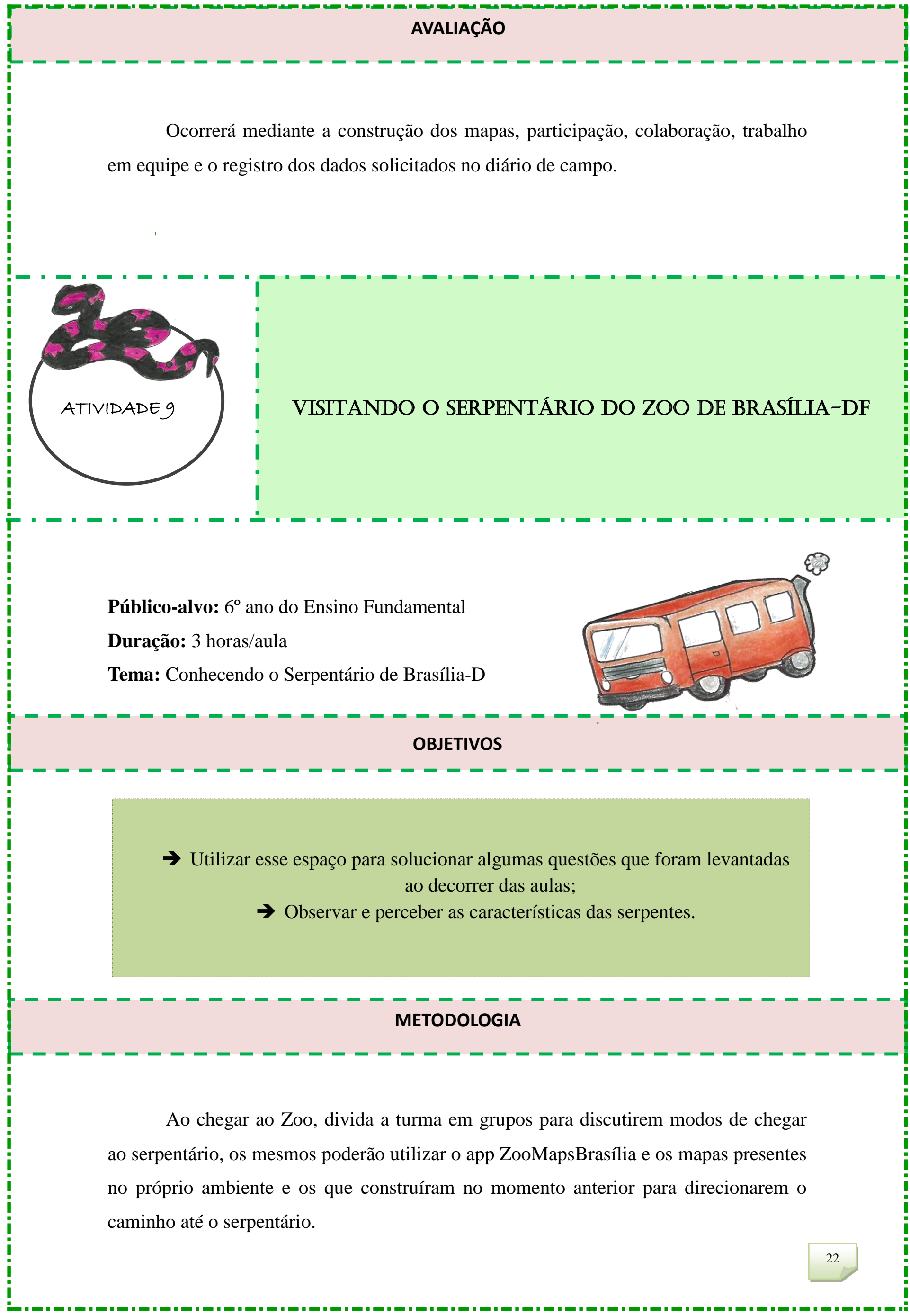


No serpentário, será instituído um momento "Tira Dúvidas” onde os educandos poderão utilizar esse espaço para tentar solucionar as questões que eles anotaram no diário de campo ao decorrer de todas as atividades propostas.

Após essa etapa, exponha as seguintes questões investigativas:

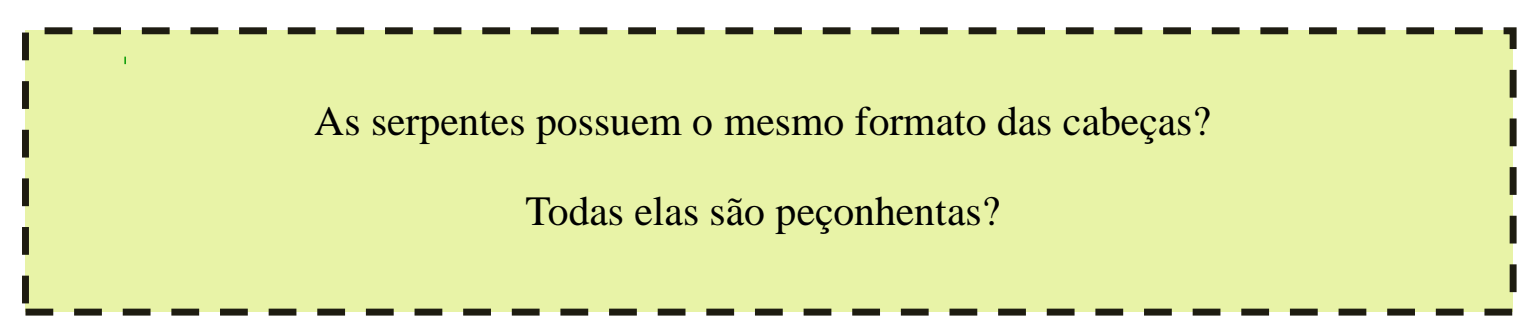

Assim, oriente que os discentes desenhem o formato da cabeça e suas respectivas informações no diário de campo, no intuito que eles relacionem, em sala de aula, peçonha x formato da cabeça.

Posteriormente, exponha uma nova questão investigativa:

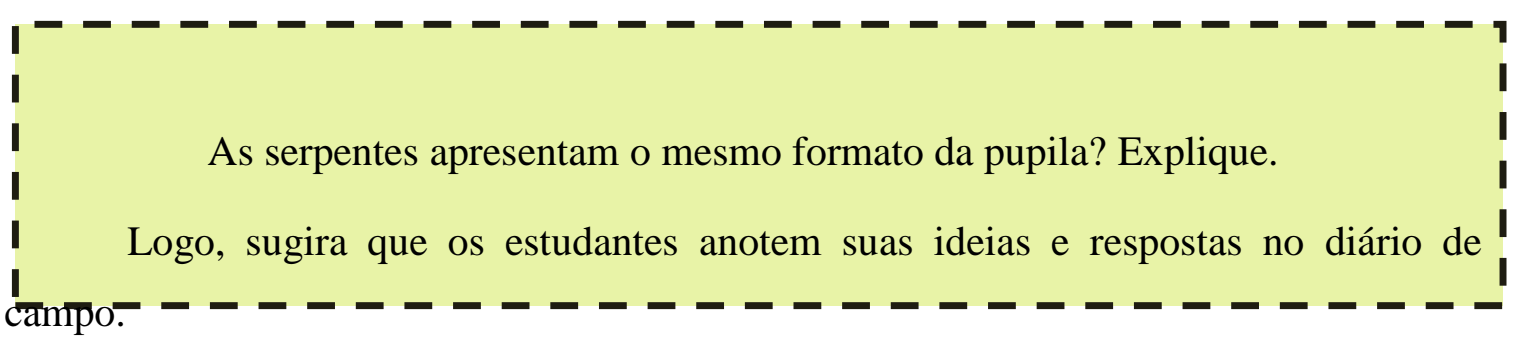

\section{RECURSOS DIDÁTICOS E MATERIAIS}

Os recursos didáticos a serem utilizados nessa atividade envolvem o serpentário, diário de campo, lápis e borracha.
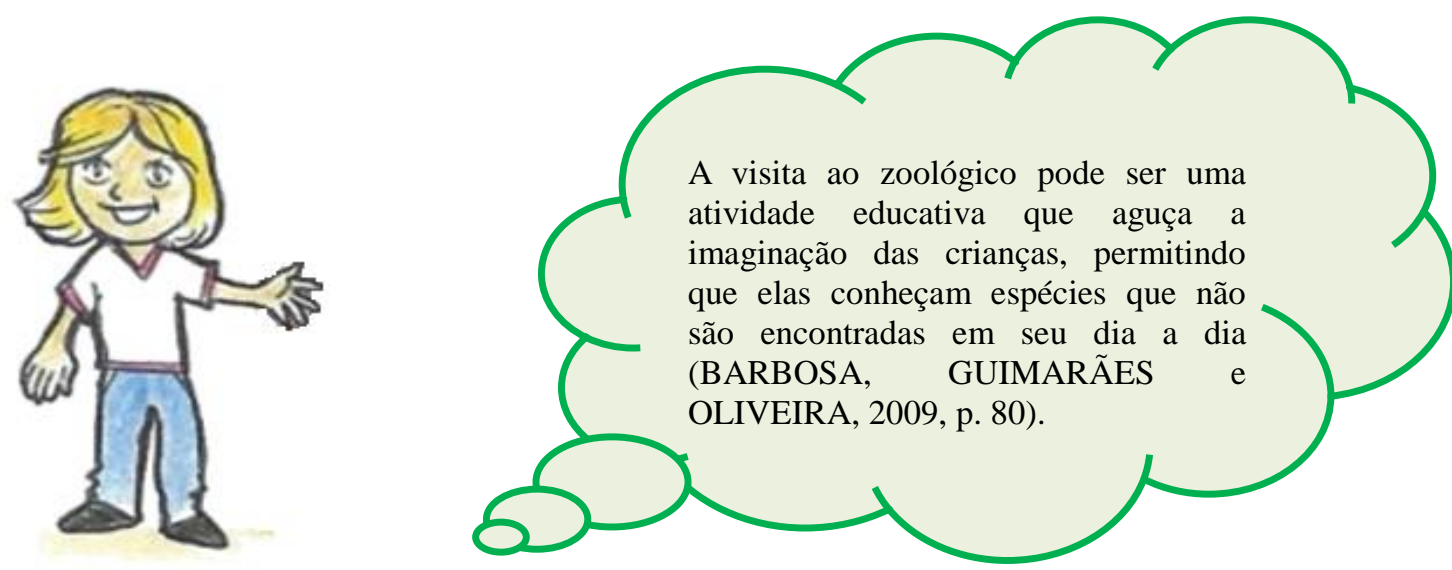


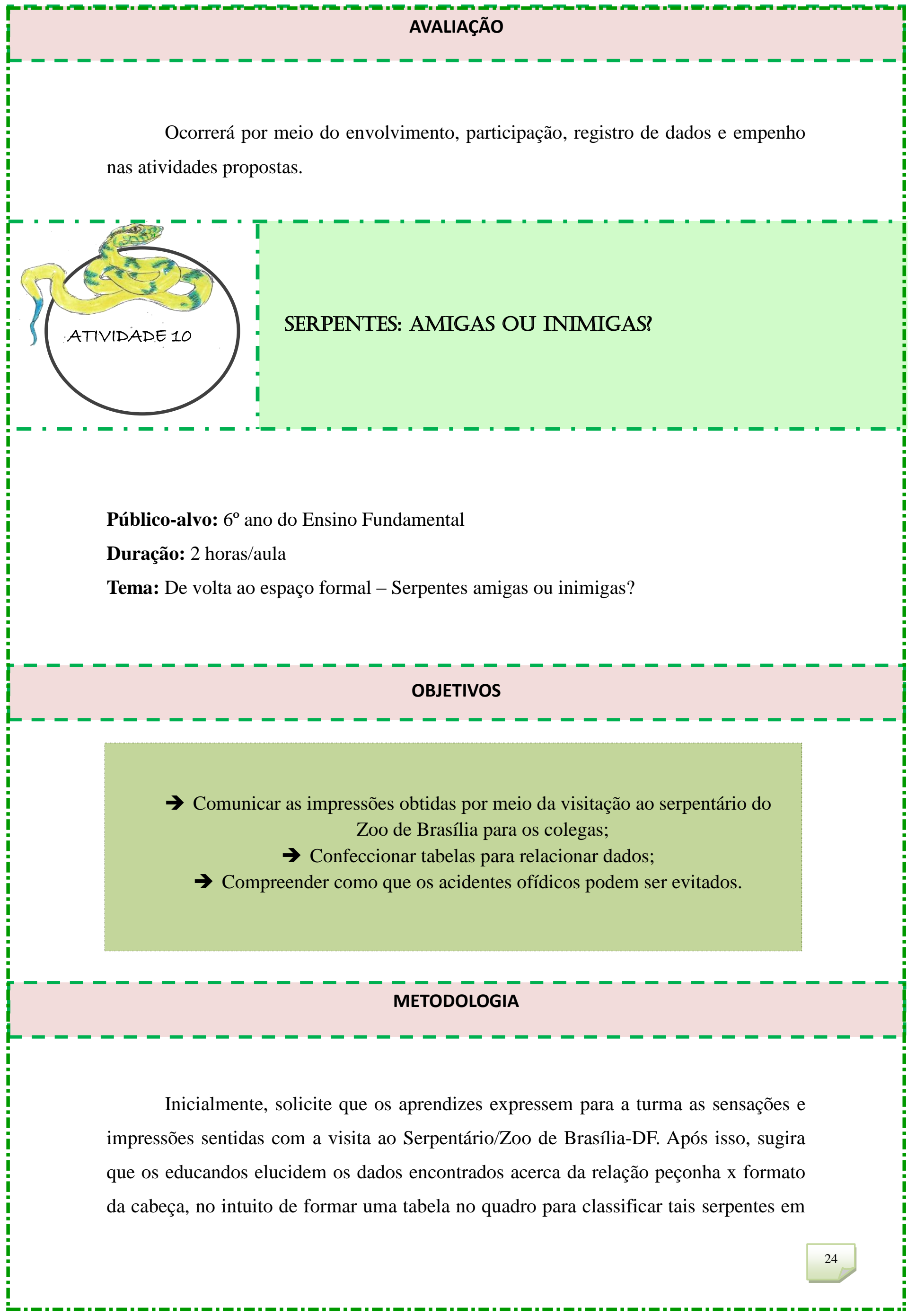


peçonhentas, semi peçonhentas e não peçonhentas. Depois da etapa anterior, peça que os mesmos também façam a relação atividade $\mathrm{x}$ formato da pupila. Para complementar a discussão, acerca da relação da peçonha, distribua duas histórias em quadrinhos com uma questão investigativa cada (Anexo 2 e 3). Assim, oriente que os mesmos registrem no diário de campo suas opiniões e ideias a respeito das indagações.

Assim, requeira que eles pesquisem, em casa com os seus amigos e familiares, casos de acidentes ofídicos nas regiões do Distrito Federal e Entorno e anotem no diário de campo como as vítimas reagiram a tal fato, como aconteceu e quais medidas foram tomadas. Em outro momento, os aprendizes devem divulgar as informações recolhidas.

\section{RECURSOS DIDÁTICOS E MATERIAIS}

Para essa atividade, serão utilizados os seguintes materiais: diário de campo, quadro branco, lápis, borracha e duas histórias em quadrinhos com questões investigativas.
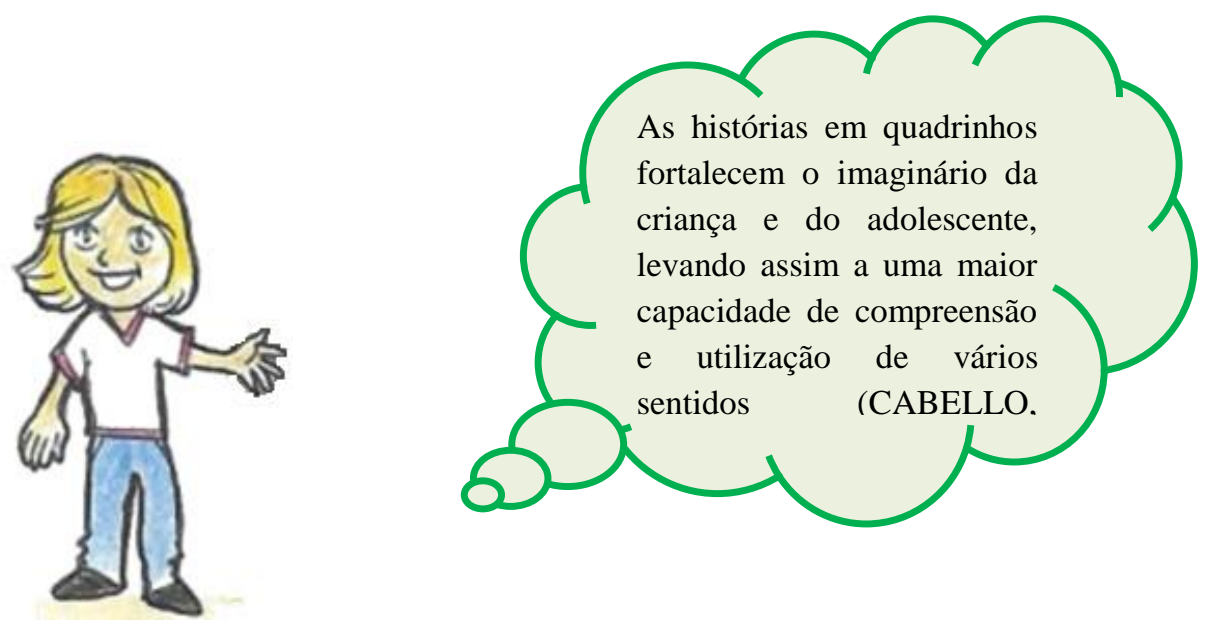
Anexo 2
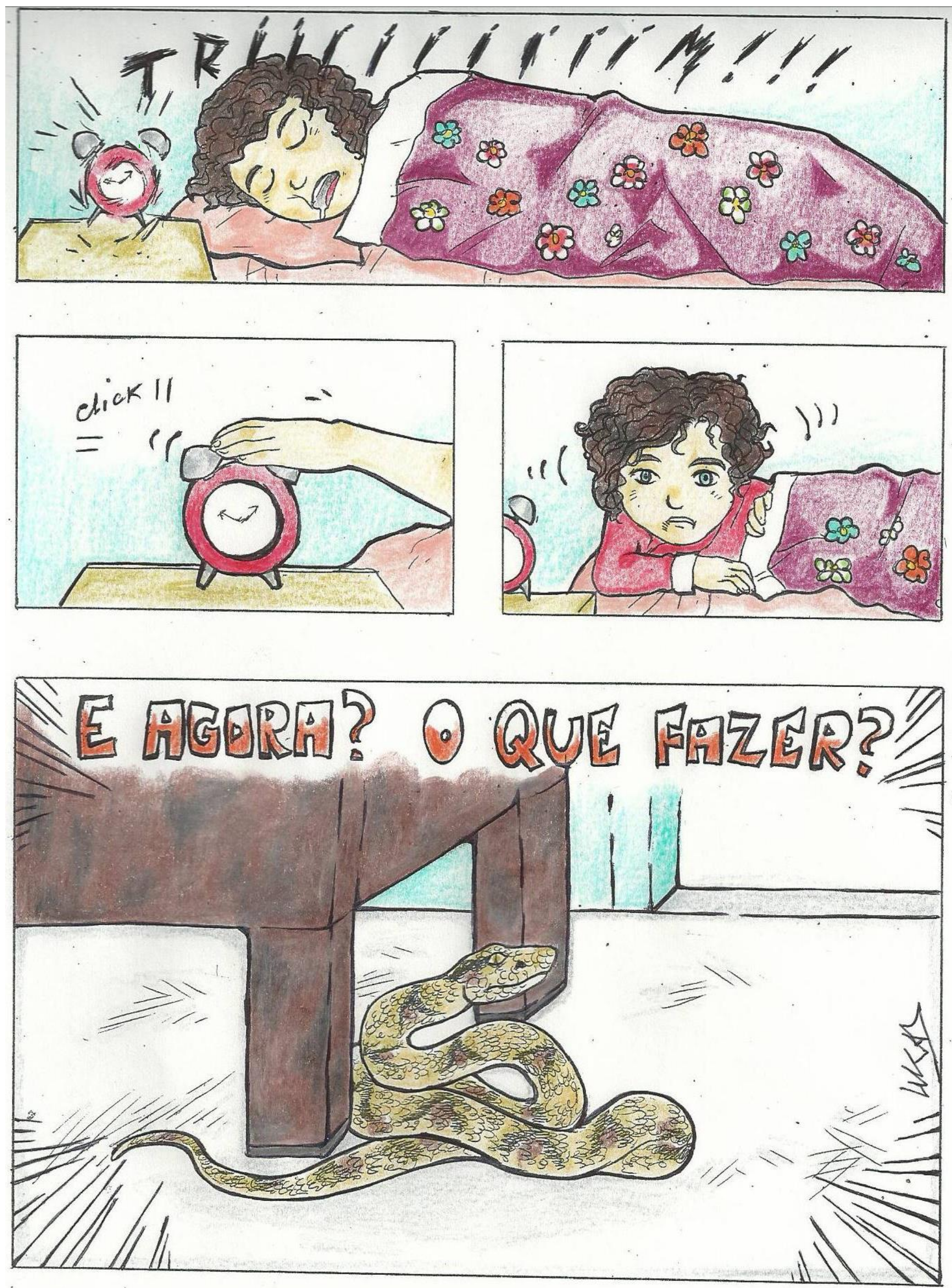


\section{Anexo 3}
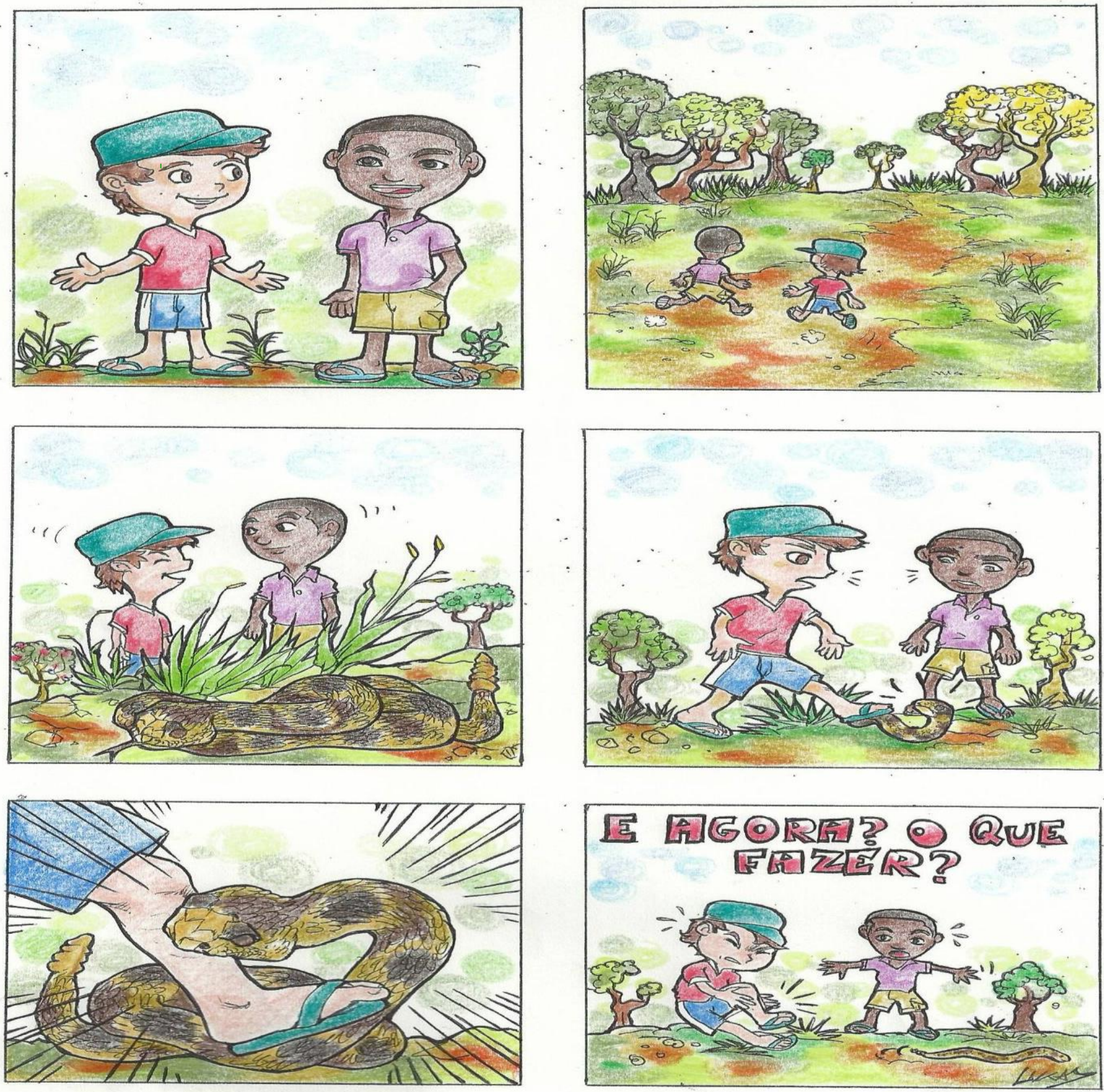

\section{AVALIAÇÃO}

Acontecerá mediante o envolvimento dos educandos para a resolução das questões e pesquisa proposta, além do trabalho em equipe. 


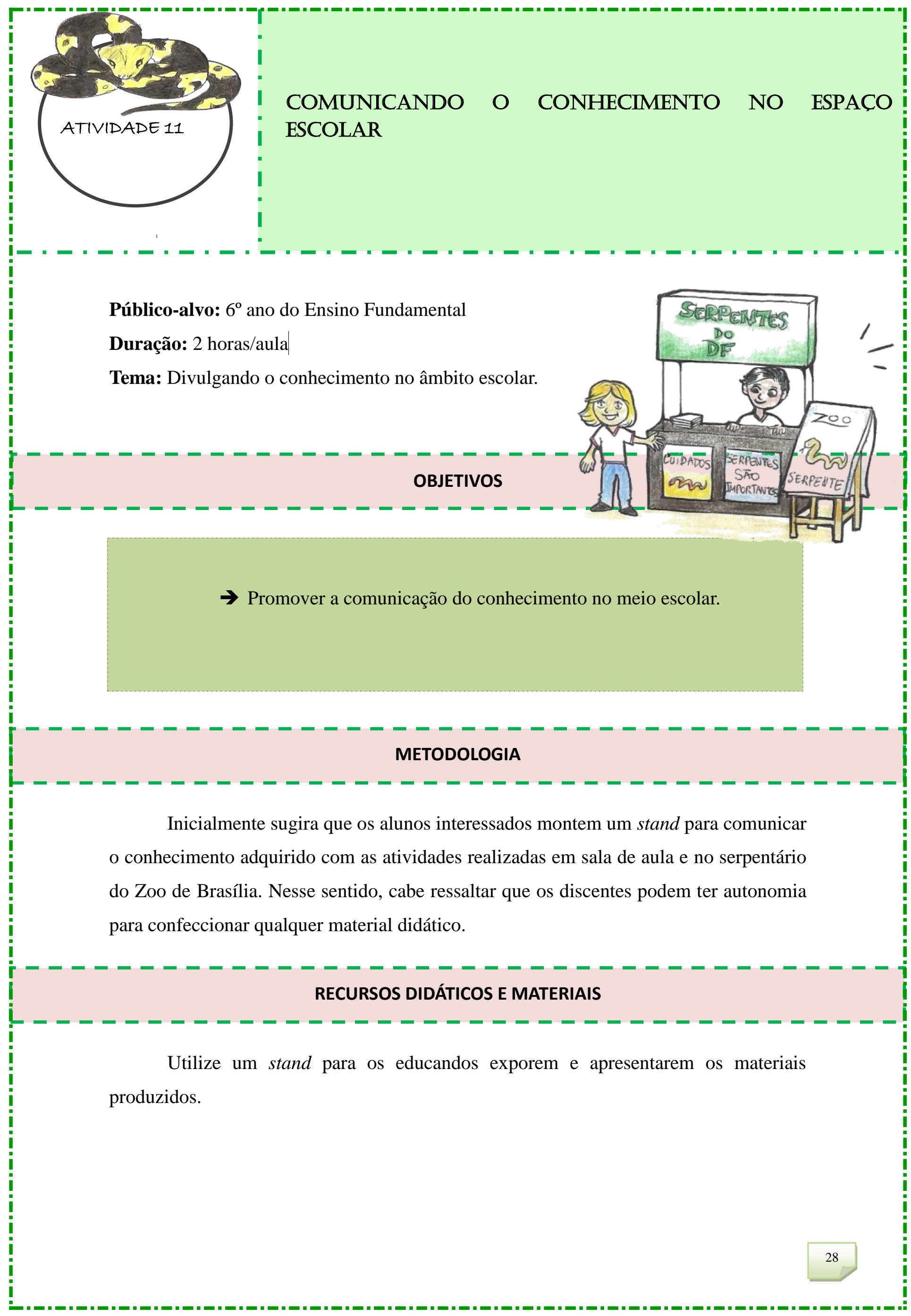


Ocorrerá mediante o envolvimento, planejamento, organização e o desempenho dos alunos para a construção dos materiais.
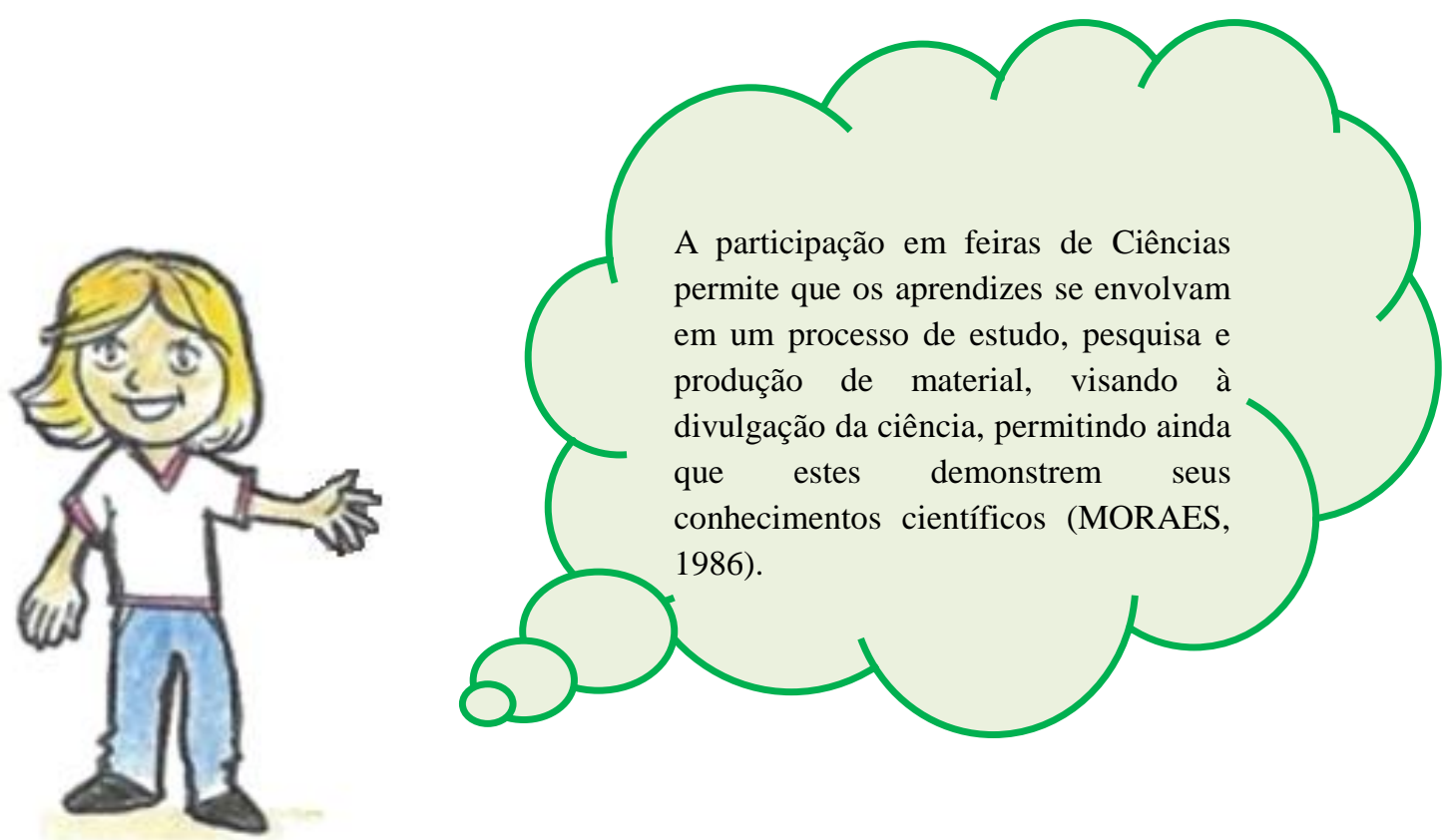


\section{GLOSSÁRIO PARA O(A) PROFESSOR(A)}

Atividades investigativas: são atividades compostas de problemas experimentais ou teóricos contextualizados, que fornecem aos aprendizes momentos para refletirem, formularem hipóteses, sistematizar dados e comunicar resultados obtidos por meio da resolução do problema.

Conteúdos procedimentais: tipo de conteúdo de aprendizagem prático que consiste em processos ou ações cuja aprendizagem requer um modelo prévio e uma exercitação posterior.

Conteúdos atitudinais: tipo de conteúdo de aprendizagem que se enquadra na forma de ser da pessoa e cuja aprendizagem requer experienciação de situações nas quais se deva agir de forma real para solucioná-las. Envolve ações como colaborar, cooperar, mostrarse motivado para o estudo da i ciência e outros.

Serpentes peçonhentas: possuem presas anteriores, com orifício central ou sulco; fosseta loreal presente (exceto no gênero Micrurus).

Serpente não peçonhentas: não possuem presas anteriores e fosseta loreal, dessa forma não existe a inoculação de veneno.

Serpentes semi peçonhentas: produzem saliva tóxica, possuem a capacidade potencial de provocar envenenamento, no entanto os dentes não chegam a injetar o veneno em uma rápida mordida. 


\section{REFERÊNCIAS BIBLIOGRÁFICAS}

BARRETO K. F. B.; GUIMARÃES C. R. P.; OLIVEIRA I. S. S. O zoológico como recurso didático para a prática de Educação Ambiental. Revista FACED, Salvador, n.15, jan./jul. 2009.

BONITO, J. Perspectivas actuais sobre o ensino das ciências: clarificação de caminhos. Terra e Didatica, v. 4, n. 1, p. 28-42, 2008.

BRITO, A. G. O Jardim Zoológico enquanto espaço não formal para promoção do desenvolvimento de etapas do raciocínio científico. (Dissertação de Mestrado) 114p. Programa de Pós Graduação em Ensino de Ciências, Universidade de Brasília, DF, 2012.

CABELLO, K. S. A.; DE LA ROCQUE, L.; SOUSA, I. C. F. Uma história em quadrinhos para o ensino e divulgação da hanseníase. Revista Electrónica de Enseñanza de las Ciencias, v. 9, n. 1, p. 225-241, 2010.

CARVALHO, A. M. P. Ensino de Ciências por investigação: condições para implementação em sala. São Paulo: Cengage Learning, 2013.

Correio Brasiliense. Disponível em:

http://www.correiobraziliense.com.br/app/noticia/cidades/2015/01/11/interna_cidadesdf, 465702/estudante-cria-aplicativo-com-mapa-e-informacoes-sobre-o-zoologico.shtml Data de acesso: 12 Jun 2015

GRILLO e ORGs. A gestão da aula universitária na PURCS. Porto Alegre: ediPURCS, 2008.

KISHIMOTO, T.M. Jogo, brinquedo, brincadeira e a educação. São Paulo: Corte, 1997.

MARANDINO, M.; SELLES, S. E.; FERREIRA, M. S. Ensino de Biologia: Histórias e Práticas em Diferentes Espaços Educativos. São Paulo: Cortez, 2009.

MELEIRO, A.; GIORDAN, M.. Hipermídia no Ensino de modelos Atômicos. Revista Química Nova Na Escola nº10, Novembro,1999, p.17-20.

MORAES, R. Debatendo o ensino de ciências e as feiras de ciências. Boletim Técnico do Procirs. Porto Alegre, v. 2, n. 5, p. 18-20, 1986. 
PINHO F. M. O; PEREIRA I. D. Ofidismo. Rev Assoc Med Bras. 2001; 47(1): 24-9.

POZO, J. I.; CRESPO, M. A. G. A aprendizagem e o Ensino de Ciências: do conhecimento cotidiano ao conhecimento científico. Porto Alegre: Artmed, 2009.

ROCHA, M. B. Contribuições dos textos de divulgação científica para o ensino de Ciências na perspectiva dos professores. Acta Scientiae, v.14, n.1, jan./abr. 2012.

SOUTO, D. R. Veneno do Saber: Análise de um Material Didático para o Desenvolvimento do Pensamento Científico no Ensino de Serpentes. 24p. Monografia. Faculdade UnB de Planaltina, 2013.

ZABALA, A.; ARNAU, L. Como aprender e ensinar competências. Porto Alegre: Artmed, 2010. 